

\title{
A TIPOGRAFIA CUSTOMIZADA COMO ELEMENTO IDENTITARIO EM SISTEMAS DE IDENTIDADES VISUAIS \\ Um estudo sobre o desenvolvimento de fontes digitais personalizadas
}

Luciano Cardinali 


\section{A TIPOGRAFIA CUSTOMIZADA}

COMO ELEMENTO IDENTITÁRIO EM

SISTEMAS DE IDENTIDADES VISUAIS

Um estudo sobre o desenvolvimento de fontes digitais personalizadas

Luciano Cardinali 
Luciano Cardinali

\section{A TIPOGRAFIA CUSTOMIZADA \\ COMO ELEMENTO IDENTITÁRIO EM \\ SISTEMAS DE IDENTIDADES VISUAIS}

Um estudo sobre o desenvolvimento

de fontes digitais personalizadas

Exemplar revisado e alterado em relação à versão original

sob responsabilidade do autor e anuência da orientadora.

São Paulo, 14 de Julho de 2015

Orientaçăo:

Profa. Dra. Priscila Lena Farias

Dissertação de mestrado apresentada à Faculdade de

Arquitetura e Urbanismo da Universidade de São Paulo

como requisito parcial para a obtenção do título de Mestre

em Arquitetura e Urbanismo.

Área de Concentração: Design e Arquitetura

Linha de Pesquisa: Projeto, Processos e Linguagens em Design 
Autorizo a reprodução e divulgação total ou parcial deste trabalho. por qualquer meio convencional ou eletrônico, para fins de estudo e pesquisa, desde que citada a fonte.

-mail do autor:

uciano@consoloecardinali.com.br
CARDINALI, Luciano

A TIPOGRAFIA CUSTOMIZADA COMO ELEMENTO IDENTITÁRIO

EM SISTEMAS DE IDENTIDADES VISUAIS

Dissertação de mestrado apresentada à Faculdade de Arquitetura e Urbanismo da Universidade de São Paulo como requisito parcial para a obtençāo do título de Mestre em Arquitetura e Urbanismo.

\section{Data: $/ 1$}

Banca examinadora

Julgamento:

Profa. Dra. Priscila Lena Farias - orientadora

Universidade de São Paulo

Julgamento:

Instituição:

Julgamento:

266 p. : it.

Dissertação (Mestrado - Área de Concentração: Design e Arquitetura) - FAUUS

Orientadora: Priscila Lena Farias

1Tipografia 2.Identidade visual (Sistemas) 3.Personalidade 4.Tipografia customizada 5.Tipografia personalizada aplicada I.Título
Instituição:

\begin{tabular}{ll}
\cline { 2 - 2 } Julgamento: & Nome: \\
& Instituição: \\
Julgamento: & \\
& \\
& Nome (suplente): \\
& Instituição: \\
Julgamento: & \\
& Nome (suplente): \\
& Instituicão:
\end{tabular}



dedicação e precisão nos detalhes durante todo o desenvolvimento deste trabalho. Foi por isso que a escolhi como orientadora.

Aos Profs. Drs. Anna Paula S. Gouveia e Marcelo M. Bicudo, pela importante contribuição dada no momento da qualificação oferencendo os seus pontos de vista e experiência em suas áreas de especialização.

Aos designers de tipos Paul van der Laan, Christian Schwartz, Jean François Porchez, pela atenção e contribuição na medida do possível considerando o tempo exíguo de que dispõem. Um agradecimento especial a Matthew Carter, um mito da história da tipografia, que cedeu seu precioso tempo para ajudar no que lhe foi possível e pela amostra inestimável da fonte Walker, a qual puder explorar em detalhes e produzir um bom material para esta dissertação. Da mesma forma, agradeço ao trio da Dalton Maag, Bruno Maag, amigo de mais de uma década, a Fernando Caro e Fabio Haag, designers de excelência que contribuíram com material inédito e imprescindível para conhecermos melhor a fonte Petrobras Sans. Ao designer de tipos Eduilson Wessler Coan da dooType que, em plena véspera de Natal, estava trabalhando em mais uma nova fonte e dispôs daquele inestimável momento para contribuir com sua experiência.

Aos amigos Marcello Montore, pelo apoio e ajuda nos questionários das entrevistas: João de Souza Leite, pela frase que me inspirou durante a dissertação: "você tem que entrar em transe..." e Vânia Cavalcanti, que não titubeou em sacrificar seu Carnaval em troca da revisão dos textos.

Às culturas africana e árabe, por terem nos proporcionado o café, sem o qual seria quase impossível concluir qualquer raciocínio.

Ao meu filho Theo, pela ajuda, paciência e por saber esperar o momento possível para podermos ir ao parque, tomar água de coco e jogar bola.

E o agradecimento especial à Cecilia Consolo, minha melhor amiga, namorada e companheira de toda a vida por, simplesmente, tudo o que tenho, faço e sou. 


\section{Abstract}

This work studies the procedures and methods used by type designers for conceiving and developing custom digital fonts used exclusively in corporate identity systems. By exploring the expressive potential of these fonts and with regard to contemporary typography, the investigation tried to recognize their connotative, historical, cultural and emotional attributes as well as possible meanings and interpretations these shapes may evoke.

Besides playing an important role in many graphic design areas, CUSTOM TYPEFAFECES AS digital fonts are key elements to corporate identities. This study's goal is AN INDENTITY ELEMENT IN to outline the decisions adopted in the process of designing and creating

VISUAL IDENTITY SYSTEMS. the formal structures of six custom digital corporate fonts, based on information from their designers, in published texts and the author's own analyzes. In a broader sense, the study draws attention of designers and clients who hire type design services, on the need for a more careful choice and or adoption of fonts that make up a particular corporate identity. Thereby, the typography should be considered as an authentic agent for consolidating that identity through its formal, expressive and connotative qualities.

Despite the subjectivity in the evaluation, the outcome is that the typography is able to carry and transmit the identity of a company or institution even when the the logo is absent. Along with the content of the message, it takes on the role of carrying the values, behavior and personality of the brand. In this sense, the customized corporate font, that is, the font specially developed or adapted for that purpose is believed to play a fundamental role which this study sought to find out.

\section{Keywords:}

Typography; Typeface Design; Visual Identity Systems

Typeface Personality; Custom Typeface;

Applied Custom Typeface

Resumo Esta dissertação investiga os procedimentos e métodos empregados

por designers de tipos para a concepção e o desenvolvimento d fontes digitais customizadas, associadas exclusivamente a sistemas de identidades visuais corporativos, explorando o potencial expressivo dessas tipografias, procurando identificar seus atributos conotativos, históricos, culturais e emocionais, assim como os possíveis significados e interpretações que estas formas podem evocar, com atenção especial para a tipografia contemporânea.

Fontes digitais são elementos centrais para a consolidação de uma

A TIPOGRAFIA

CUSTOMIZADA COMO

ELEMENTO IDENTITÁRIO

EM SISTEMAS DE

IDENTIDADES VISUAIS

identidade visual, além do importante papel em muitas outras especialidades do design gráfico. O objetivo prático desse estudo é delinear as decisões adotadas no processo do design e da estrutura formal de seis fontes digitais personalizadas, para uso corporativo exclusivo, baseando-se em informações coletadas diretamente dos designers envolvidos, em textos publicados e análises próprias. Em um sentido mais amplo, o estudo visa colaborar com designers e contratantes de serviços de design tipográfico, sobre a necessidade de uma atenção mais ponderada no momento da escolha ou adoção dos tipos que compõem uma determinada identidade visual, considerando a tipografia um agente consolidador de uma identidade autêntica, por meio das qualidades formais, expressivas e conotativas dos tipos.

Apesar da subjetividade nas avaliações que o tema envolve, o resultado observado é que a tipografia tem condições de carregar e transmitir a identidade de uma instituição, até mesmo nas situações em que a própria marca está ausente, assumindo o papel de transportar, juntamente com o conteúdo da mensagem, valores, comportamentos e personalidade. Neste contexto, a tipografia corporativa customizada, ou seja, aquela desenvolvida e adaptada especialmente para este fim, desempenha um importante papel, o que esta dissertação busca elucidar.

\section{Palavras-chave:}

Tipografia; Design Tipográfico; Sistemas de Identidade Visual;

Personalidade Tipográfica; Tipografia Customizada:

Tipografia Personalizada Aplicada; 


\section{Lista de Imagens 1. TIPOGRAFIA E IDENTIDADE}

FIGURA 001_Detalhe da base da coluna de Trajano, em Roma, com inscriçăo das letras Capitalis MonuFIGURA 002_Detalhe de página do livro médailles sur les principaux, [.... Disponivel em: shttp://gallica. .

政 EIGURA 004_ Detalhe do tipo Fraktur em página do livro Fausto, [..... Disponivel em: <http://commons

FIGURA 005_Cartaz que anuncia encontro nazista em Berlim, [.... Disponivel em: < http://artreverb. co.uk/the-history-and-use-of-blackletter/ > . Acesso em: 05 Jan. 2015

FIGURA 006_A fonte Fontana ND, ..... Disponivivel em: < http:///www.unostiposduros.com/grandes-tipos

EIGURA 007_Convite para conferência, design de Jan Tschichold, [.... Disponivel em: < http:///corinnean

FIGURA 008_Marca desenhada por Peter Behrens [.... Disponivel em: < https://secidiooo.wordpress.com/

FIGURA 009_Capa do convite para "a exposiçăo de AEG, [.... Disponível em: chttp://newhousebooks.

tumbli.com//0ost/10538875911/detail-from-aeg-flyer-by-peter-behrens-Ca-913.

FIGURA 010_Poster desenhado por beherens em 1912. para Ventiladores
http://www.tipografos.net/design//behrens.htmls. Acesso em: 17 Jan. 2015.

FIGURA 011_ O primeiro design das letras, de 1908, I.... Disponivivel em: shttp://abdulazizfarache.blogspot. com.br>. Acesso em: 17 Jan. 2015 .

FIGURA 012 _ Cartaz de Peter Behrens para AEG sobre lâmpadas elétricas, [..... Disponivel em: <www.

EIGURA 013_ Página de catálogo para chaleiras, …., Disponn.em: <www.fontecedro.it>. Acesso em: 17 Jan. 2015. FIGURA 014_Amostra do tipo Behrens Antiqua. Disponivivel em: : httpp://www.fontbros.com/families/

FIGURA 015_Detalhes do Brand Book digital da Ford, [..... Brand Book Ford, disponível em: < , www.

FIGURA 016_Amostra do uso da tipografia em anúncios, ..... Brand Book Ford (PDF), disponível em: <wwwthebrandbookcom> Acesso em: 19 Jan. 2015

EIGURA 017 Página do Brand Book da Futurice apresentando a tipografia corporative Museo Sans Brand Book Futurice (PDF), disponível em: <www:thebrandbook.com>. Acesso em: 19 Jan. 2015. FIGURA 018_Detalhe da pagina do brand book Carrefour, [...]. Brand Book Carrefour (PDE), disponíve em: <www.thebrandbook.com>. Acesso em: 27 Jan. 2014.

FIGURA 019_Página do site que apresenta a fonte British Coucil Sans, [.... Disponivel em: shttp://brand.

FIGURA 020_Pagina do brand book que apresenta recomendaçoes de uso, [..... Disponivivel em: <http:/

FIGURA 021_Quadro demonstrativo das particularidades da fonte British Council Sans, [..... Disponivel.

FIGURA 022_ Fragmento do portal de notícias do website do Governo Federal Alemão, [....]. Disponivivel



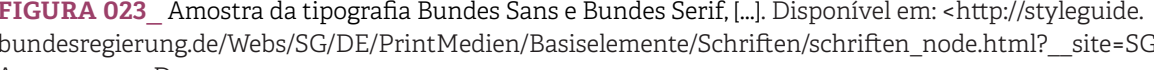

IGURA 024_Redesenho da tipografia Univers Bold 693, [...., (CAUDURO, 1972:04, vol. II). FIGURA 025_A tipografia Univers Bold 65, da Linotype, [.... Figura produzida pelo autor. FIGURA 026_A planificação do módulo de fracionamento métrico, [..... (CAUDUURO, 1972:6, vol. II EIGURA 027_Especificaçăo dos espaçamentos entre letras, [...]. (CAUDURO, 1972:50, vol. II FIGURA 028_Testes de legibilidade do alfabeto, [...]. (CAUDURO, 1972:63, vol. I]

\section{O CARÁTER DOS CARACTERES}

IGURA 029_Cartaz de 1891 que divulga o leilâa de uma fazenda, [..... Peça da coleçăo do Centre for magem produzida pelo autor. IIGURA 030 Tabela referente à classificação da tipografia Bodoni Bold no experimento realizado po Poffenberger e Franken, [.... (POFFENBERGER e ERANKEN, 1923:316).

FIGURA 031_Tabela de conclusão dos testes de Kastle Child, [...]. (KASTL e CHILD, 1968:4444). FIGURA 032_ Lista dos 22 pares de conceitos opostos usado nos testes. (HOFMAN, 1988:12).

FIGURA 033_Amostras da Garamond Monotype, [.... Figura produzida pelo autor.

FIGURA 034_Escala de atributos da pesquisa de Eva R. Brumberger, [.... (BRUMMBERGER, 2003:210)

EIGURA 035 As 20 tipografias usadas nos testes de Chaparro. Foxe Shaikh em 2006 r realizados on A maioria, (...) (CHAPARRO; FOX; SHAIKH, 2006, s...).

FIGURA 036_As 20 fontes distribuidas nas categorias de adjetivos, [...) (CHAPARRO; FOX; SHAIKH, 2006, s.n. EIGURA 037 Comparação entre alguns caracterese-chave da Helvetica e Univers, I..... Figura produzida pelo autor.

FIGURA 038_A mesma tipografia apresentada em duas situaçōes diferentes, [.... Figura produzida pelo

FIGURA 039_Tipografia Foundry Fabriek Bold, ,.... Disponivel em: <http://www.foundrytypes.co.uk/theFIGURA 040_ A fonte Agency FB de David Berlow, 1995, um redesign do tipo criado por Morris Fuller

FIGURA 041_Comparação entre caracteres-chave da FS Millbank, Petrobras Sans e Parisine, [..]. Figura

\section{TIPOGRAFIA CORPORATIVA PERSONALIZADA}

FIGURA 042_Página The Century Magazine, [.... Disponivel em: ‘ http:///showinfor.ietveldacademie.n/

em: chttps://poojasaxena.wordpress.com/2012/03/20/ chasing-curiousities/>. Acesso em: 02 J Jan. 2015

FIGURA 044_ Tipografia Folha Serif, de Lucas de Groot, [.... Imagem digitalizada de página do jornal. FIGURA 045_Marca de William Golden para a CBS Television, [.... Disponivivel em: <myfriendsplace.org> Acesso em: 06 Jan. 2015.

FIGURA 046_CBS Didot, desenhada por Freeman Craw, [...] Disponivel em: <www.welovetypography.

FIGURA 047_ A tipografia CBD Didot em mostradores de relogio, [.... Disponivel em: shttp://www.burnir-

1986. I. MELLO COIMBRA, 2011.5 EIGURA 048b A tipografia para a Bardhal, em 1988. (MELLO e COIMBRA, 2011:527). FIGURA 049_- Comparação dos espacamentos entre a fonte Liberation Sans e a Arial da Monotype. svg?. Acesso em: 08 Jan. 2015

FIGURA 050_ A familila de fontes UnB Pro, de 2008, [...]. Manual de Identidade da UnB (PDF) FIGURA 051_ Tabela que mostra os quatro pontos a considerar no investimento de uma fonte corporati-

IGURA 052 Caracteres da FF Meta, [.... Figura produzida pelo autor

EIGURA 053 Eshoço original feito por Erik Spiekrmann em 1985 Disponível em: <https://wrww fontfont.com/fonts/meta/in-use . Acesso em: 02 Jan. 2015.

FIGURA 054_ Esboço original feito por Spiekermann, em 1985, estuda as contra-formas, I.... Disponive . Acesso em: 02 Jan. 2015

FIGURA 055_Cartōes postais antes e depois, ..... (MIDDENDORP; SPIEKERMANN, 2006:22). 

FIGURA 056_A familia Nokia, de 2002, é grande o suficiente para atender, [...]. Disponível em: ‘http://
spiekermann.com/en/nokia-sans-character/s.Acesso em: 04 Jan. 2015.

FIGURA 057 Versōes da familia Nokia abordam questōes formais de legibilidade [I Disponivive ent <http://spiekermann.com/en/nokia-sans-character/>. Acesso em: 04 Jan. 2015. sideration.com?. Acesso em: 05 Jan. 2015

IGGURA 059_ A marca da Audi de 1987, em cima, não swww.advertiser-1n-arabia.blogspot.com>. Acesso em: 05 Jan. 2015

EIGURA 060_ Famililia Audy Type composta de quatro pesos. [..... Figura produzida pelo autor. FIGURA 061_Dois exemplos da versão modificada da fonte Fedra Sans, [...]. Disponivivel em: : hhtpp://fonts-

FIGURA 062_ Logotipo da Xerox, criado pela Interbrand, [.... Disponivel em: ‘http://www.fontsmith.com/

FIGURA 063_ Tipografia FS Albert associada a atributos emocionais da marca Xerox. Disponível em

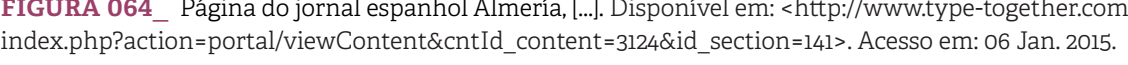

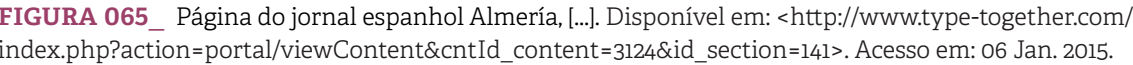
FIGURA 066_ Capas da 1 a edição de Setembro de 2010 e da $22^{a}$ ediçăo da revista Civic City Cahier, [...].

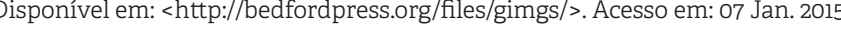
FIGURA 067_- Tipografia Axe Times em suas versooes regular e bold, [..... Disponivivel em: <http://bedfor-

FIGURA 067_Alfabeto da tipografia Axe Times Regular. Disponivel em: <http://bedfordpress.or/fliles/

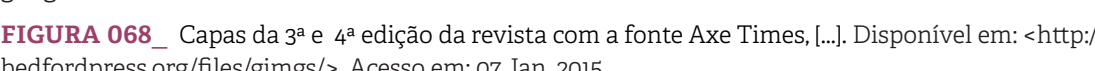

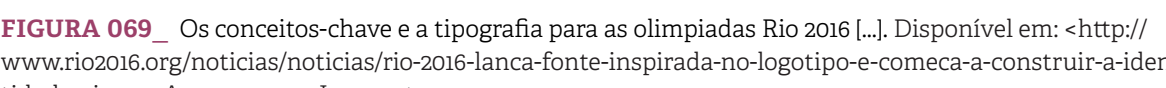
tidade-visuar. Acesso em: 12 Jan. 2015.

FIGURA 070 O O grafismo urbano e paisagens da cidade inspiraram as formas da tipografia, [.... Disponivel em: shttp:///www.rioz2016.org/noticias/noticias/rio-2016-lanca-fonte-inspirada-no-logotipo-e-comeca

\subsection{RIJKSMUSEUM, 2012}

FIGURA 071_A designer Irma Boom acompanha a reinauguraçāo do Rijksmuseum. Disponível em:


IGURA 072 Amostras da fonte Hollander de Gerard Unger, Disponivel em: < http://www.fonts.com/ font//inotype/hollander >. Acesso em: 12 Ago. 2014 .

FIGURA 073_ Decomposiçăo de seis cores a partir do quadro A Leiteira de Veermer, [.... Disponível em: ‘ htps:/Wwir.

FIGURA 073_Logotipo do museu criado pelo Studio Dumbar [...]. Disponível em: $<$ http://www.nederle FIGURA 074_A tipografia DTLL Documenta, de Frank E. Bokland [.... Disponivel em: < https://www.rijks-

FIGURA 076_Logotipo criado por Irma Boom em 2012, na versão em positivo e em negativo, [.... DisponíNov. 2013

EIGURA 077 O ditongo IJ' em sua forma espaçada normal e sua forma ligada, [.... Disponivel em: < wwrwe indiegogo.com?. Acesso em: 16 Nov. 2013 .

FIGURA 078 Comparaçáo do ditongo sem ligatura e com ligatura, [.... Disponivive em: shttp:/typophile.
FIGURA 079_Prova com estudos, na fonte DIN Miettlschriftm, para a ligadura 'IJ', [.... Imagem produzid

FIGURA 080_Prova dos estudos feitos por Boom experimentando maneiras variadas, [.].]. Imagem produ-

FIGURA 081_Amostra da fonte DIN Mittelscherift, [.... Imagem produzida pelo autor desta dissertação urante apresentaçăo na AtypI Amsterdam, 2013.

FIGURA 082 Amostras da fonte Panno Text eda Panno Sign de Pietr van Rosmalen, L... Disponivel em. < http://www.boldmonday.com/en/pannotext/>. Acesso em: 040 Out. 2014.

IIGURA 083_Tentativa de aplicara a fonte Panno Text no logotipo criou, (...). Imagem produzida pelo autor

IGURA 084_A necessidade de uma tipografia com condensação ideal, [.... Figura produzida pelo autor. FIGURA 085_Revisão das formas e proporção das letras para o logotipo [.... Imagem produzida pelo autor

FIGURA 086_Detalhe da ascendente e letreiro aplicado na sinalização interna do museu, [..... Imagen

FIGURA 087_Amostra da Rijksmuseum do logotipo, em sua versão única. I...]. Imagem fornecida por Pau

FIGURA 088_Detalhe da sinalização nas escadas, em que as letras são aplicadas em alto relevo, [...].

FIGURA 008_Amostran
Laan, Bold Monday.

IGURA 090_Amostra da familia tipografica Rijkssmuseum Label [.... Imagem fornecida por Paul van der Laan, Bold Monday.

IGGURA 091_Rijksmuseum Text Bold destacada nas partes mais importantes [.... Figura produzida pelo autor FIGURA 092_ Detalhe da fenda para áreas muito justas [... Figura produzida pelo autor.

FIGURA 093_Detalhe da sinalizaçăo interna do museu, ,.... I magem produzida pelo autor.

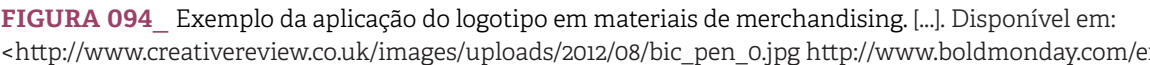
pannotext $/>$. Acesso em: 14 Nov. 2013

EIGURA 095_Uma das telas de abertura da homepage do museu, [...]. Disponivivel em: ‘https://www.

\subsection{PARISINE, 1996}

FIGURA 096_Placa de sinalizaçăo do metrô de Paris, com a fonte Parisine. [..... Disponivivel em: <https://

FIGURA 097_Sinalização interna do metrô de Paris com tipografia sem serifa, [.... Disponivel em:

hittp:/theniffyffities.tumblr.com/>. Acesso em: 28 Jan. 2015

EIGURA 098 Sinalizacão interna do metrô de Paris com a tipografia Univers .... Disponivel em. ‘htpps:/ m/gazette/post/parisine/>. Acesso em: 28 Jan. 2015

FGGURA 099_Amostra do alfabeto Metro de Adrian Frutiger, 1973. Disponivive em: <http://theredlist.com/ (2) 20.15

IIGURA 100_Sinalização da estaçăo do metrô Chaussée d'Antin La Fayette, [...I. Imagem produzida pelo autor. FIGURA 101_A Parisine Bold comparada à Neue Helvetica 75 Bold, condensada em 10\%, [..... Imagem

EIGURA 102_ As três referências básicas para a Parisine, [..... Imag. produzida pelo autor desta dissertaçăo EIGURA 103_Comparação entre a Parisine Regular e Regular Italic, [..... Imagem produzida pelo autor FIGURA 104_ Ligatura discricional (st) da Parisine, [...]. Imagem produzida pelo autor.

EIGURA 105_ A familila Parisine com termos franceses para as versőes, (..... Imagem produzida pelo autor IIGURA 106 _ Display de horariose destmos em ponto de onibus. ..... Disponivel em: «https://postedinparis.wordpress.com//ategory/getting-around-town/page/2/>. Acesso em: 03 Fev. 2015 
FIGURA 107_Mapa da rede de transportes de Paris abrangendo metrô, trens (RER) e bondes, [.].].
Disponivel em: <wWw.phys.ens.fr/IMG/pdf/plan_metro_simple.pdf $>$. Acesso em: 03 Fev. 2015.


rie.com/gazette/post/parisine/s. Acesso em: 08 Jan. 2015

EIGURA 109_O conjunto básico da Parisine Office com apenas 4 estilos. Imagem do espécimen PDE fornecido no site da Typofonderie. FIGURA 110_As três versōes em uso em tela de LEDs, [..... Disponivel em: <http://www.zecraft.com/fonts
parisine-girouette>. Acesso em: 03 Fev. 2015.

FIGURA III__Amostra com as três versōes da Parisine Girouette. Disponivivel em: shttp://www.zecraft.

EIGURA 112 Teste comparativo entre a Parisine Girouette Frontale e o alfabeto usado anteriormente, [...

FIGURA 113 _ Parisine Bold destacada nas partes mais importantes dos caracteres chave. Imagem

dissertaçäa

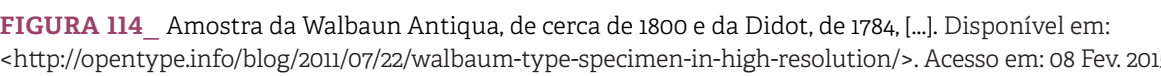
EIGURA 115_Sinalização genérica composta em Neue Helvetiva, [.... Disponível em: ‘https://typofonderie.com/gazette/post/parisine/>. Acesso em: 09 Fev. 2015 .

FIGURA 116_Página de Relatório Anual da RATP, [.... Disponivivel em: ‘ http://typofonderie.com/in-use/s, Acesso em. og rev. 2015 .

FIGURA 117_Placa de sinalização de horários do sistema de transportes RATP. Disponivive em: <http:

\subsection{GUARDIAN EGYPTIAN E GUARDIAN SANS, 2005}

FIGURA 118_Capa do Guardian de 13 de fevereiro de 2015. Disponivel em: ‘http://guardian.newspaperdi-




dian.com/media/gallery/2011/may/05/the-guardian-19oth-anniversary-picturess. Acesso em: 21 Jan. 2015 . EIGURA 121_Exemplar de 1969 cujo nome assume, I.I. Disponivel em: shttp://www.theguardian.com/ media/gallery/201//may/05/the-guardian-19oth-anniversary-pictures>. Acesso em: 21 Jan. 2015.


media/gallery/201/may/o5/he-guaddant-goth-anniversary-picturess. Acesso em: 21 Jan. 2015. FIGURA 123_Logotipo criado por David Hillman em 1988, [..... Disponivivel em: <www.maximilianareis

GURA 124_Comparaçăo dos logotipos do The Guradian, [I... Figura produzida pelo autor.

EIGURA 125 Capa da ediçăo de 12 de Setembro de 2005 que inaugurou o novo projeto gráfico, [.... DisponiAcesso em: 09 Nov. 2013.

FIGURA 126 Cabecalho da edicăo de fim de semana mantém a faixa azul, I.... Disponível em: <http:/ www.theguardian.com/media/201//sep/15/price-guardian-rises. Acesso em: og Jan. 2015

FIGURA 127_Capa da edição de 17 de Janeiro de 2012, [..... Disponivivel em: chttp:///ebookbrowsee.net/g177janfirp-pdf-d340943066 $\rightarrow$. Acesso em: og Nov. 2013 .

FIGURA 128 _Capa do suplemento Work, de 17 de Setembro de 2005, (...). Disponivel em: shttp://designob-

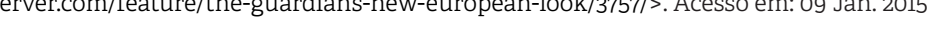

FIGURA 129_Comparacăo entre a Neue Helvetica 95 Black ea Neue Haas Grotesk Black, [....]. Disponível en

FIGURA 130 Esbocos de al

FIGURA 131_Amostra da tipografia Haçienda, desenhada por Paul Barnes, [..... Imagem produzida pelo
FIGURA 132_ Estudo de Paul Barnes mostra como um tipo sem serifa [..... (FRANCHI, 2013:110). EIGURA 133 Evolucão da tipografia Hacienda para um tipo serifado [... (ERANCHI. 2013:110. EIGURA 134 Amostra dos pesos da Guardian Egyptian Headline. PDE. Disponivivel em. chttpss/leommercialtype.com/typefaces/guardian $>$. Acesso em: o2 Mar. 2014

FIGURA 135 _Amostra dos pesos da Guardian Egyptian Text. PDE. Disponivel em: zhttps://commercialtype. com/typefaces/guardian>. Acesso em: 02 Mar. 2014

FIGURA 136_Principais diferenças entre as versōes Headline e Text, [...]. Figura produzida pelo autor. FIGURA 137_ As itálicas da versão Headline são, [.... Figura produzida pelo autor.

FIGURA 138_ Guardian Egyptian Text aplicada ao texto, [.... PDE. Disponivel em: shttps://commercialtype. com/typefaces/guardian?. Acesso em: 02 Mar. 2014

FIGURA 139_As três versōes da Guardian Sans: Text, Headline e Agate, [.... PDE. Disponivel em: <https:"

EIGURA 140_Variaçōes de peso e condensaçōes da Guardian Sans Headline, [..... PDE. Disponível em.

IGURA 141 Guardian Sans Text, projetada para textos pequenos, [...1. Figura produzida pelo autor FIGURA 142_ Detalhe da letras ' $M$ ' da Bell Centennial, de Matthew Carter, ,..... PDE. Disponivel em: shttp:

.

FIGURA 144_ Gurdian Egrptian Headline Regular. L.... Figura produzida pelo autoe:

FIGURA 145 Detalhe da serifa da Guardian Egyptian Headline: [LI.) Fig. produzida pelo autor desta dissertaçăo EIGURA 146_A semelhança entre a fonte Swift e a Guardian, ..... Fig. produzida pelo autor desta dissertação. FIGURA 147_ Forma compacta do logotipo The Guardian, [.... Disponivivel em: Ahttps://www.hakkalabs.co/

IGURAS 148_A presença constante e consistente da tipografia Guardian Egyptian, [...]. Disponivive em: hhttp:/Wwwddesignboom.com> Acesso em.11 Mai 2014 e imagem de tablet e celular produzidas pelo autor

\subsection{YALE, 2004}

IGURA 149 Vista do campus da Universidade de Yale. I... Disponivel em: shttp://guardian.newspaperdrect.com/epaper/viewer.aspx>. Acesso em: 04 Jan. 2015.

IGURA I50_ Os Anais da historia da Faculdade de Yale, ,..... Disponivive em: < http://en.wikikipedia.org/wikiki/ Thomas_Claps. Acesso em: 09 Jan. 2015 .

FIGURA 151_L Logotipo original desenhado por Paul Rand, (..... Disponivel em: <http://www.paul-rand.com/

FIGURA 152_Logotipo com a nova tipografia criada por Matthew Carter, ,..... Disponível em: <wwwwyale.

FIGURA 153_A tipografia Romana de Francesco Griffo, [.]. Disponível em: «http://brbb-dl.libraryyzale.edu/>

EIGURA 154 Boletim da Universidade de Yale do período de 1959-1951. [.]. Disponível em: <http./wwww noahsarkbookattic.com>. Acesso em: 21 Out. 2014.

FIGURA 155_Tipografaia Bembo da Monotype, [.... Disponível em: shttp://www.noahsarkbookattic.com>. Acesso em: 21 Out. 2014. Figura produzida pelo autor.

FIGURA 156_ Interior da Biblioteca Beinecke, Universidade de Yale. I.... Disponivel em: <www.beinecke. braryy.qale.edu/>. Acesso em: 14 Eev. 20.1 .

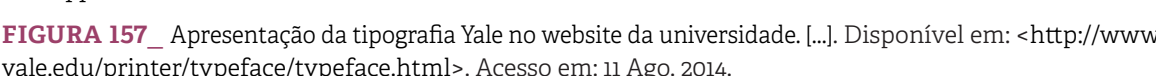

FIGURA 158_ Placa de sinalizaçăo do novo projeto, [.]. Disponivel em: «http://www.printmag.com>. Acesso

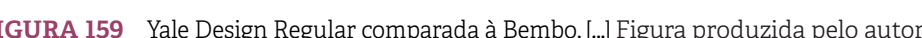

FIGURA 160 Tipografia Yale Street, I... Figura produzida pelo autor 
FIGURA 161_Yale Desiggn, versão indicada para impressos, ,.... Figura produzida pelo autor. FIGURA 162_Yale Design Italic, minúsculas não têm serifas, ..... Figura produzida pelo autor. FIGURA 163_Yale Small Capitals, [..]. Disponivivel em: shttp:///wwwyzale.edu/printer/typeface/typeface.

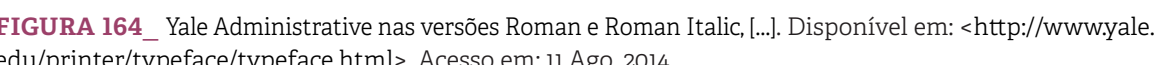

IGUURA 165 Yale Design Roman, destacada, [... Figura produzida pelo autor.

FIGURA 166_ Detalhe da serifa da Yale Design Roman, .... Figura produzida pelo autor

FIGURA 167_ Detalhe da serifa da Yale Design Roman, [.... Disponivel em: : httpp///identityyale.edu/>.

EIGURA 168 Página do Manual de Estilo Editorial. [.... Editorial Style Guide for Yale University Publications Disponivel em: ‘http://www:yale.edu/printer/bulletin/style/Editorial__guide.pdf $>$. Acesso em: 05 Jan. 2015 . FIGURA 169_Capa de livro publicado, [....Disponivivel em: ‘ http:///yalepressyale.edu/>. Acesso em: 07 Jan. 2015

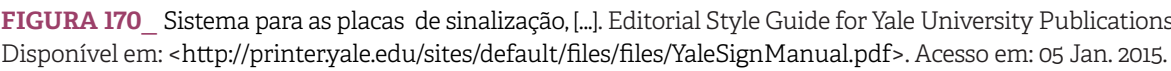
EIGURA 171_ A sinalização dos edificios em contrastes com a arquitetura do campus. (AALE UNIVERSITY,s.d.,

\subsection{WALKER, 1995}

FIGURA 172 Fachada da novas instalaç̄ese do Walker Art Center. [.]. Disponivel em: < http://guardian newspaperdirect.com/epaper/viewer.aspx $>$. Acesso em: 13 Fev. 2015.

FIGURA 173_Logotipo do WalkerArt Center, ,.... Figura produzida pelo autor.

FIGURA 174_Peça promocional connect to the New", "..... Disponivel em: <http./metamuseum.tumb

com/post/45022806060/laurie-hayycock-makela-and-matt-eller-walkers. Acesso em: 18 Fev. 2015 .

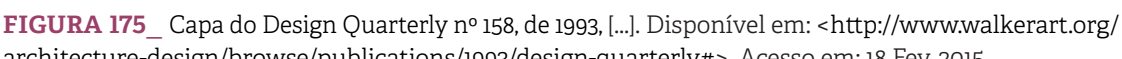

FIGURA 176_Eaxes de 9 de Janeiro de 1995 de Matthew Carter, ,..... Disponivel em: shttp://visualarts.walkeart.org/s. Acesso em: 10 Set. 204 -

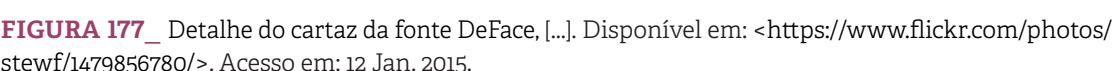

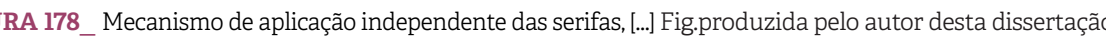
FIGURA 179 Mecanismo de aplicação dos traços de Ligação, , [...]. Fig. produzida pelo autor desta dissertação FIGURA 180 Mecanismo de aplicação das barras, ..... Figura produzida pelo autor.

FIGURA 181_ Exemplo de aplicação de serifas diferentes, [..... Figura produzida pelo autor.

FIGURA 182_Cartaz tipográfico de Kouga Hirano, [...]. Disponivel em: ‘ http:///blogs.walkerart.org/

IIGURA 183_ Problemas de posicionamento da serifa, [..... Figura produzida pelo autor.

FIGURA 184_Exemplos do uso da fonte Walker em composiç̧̄es, ,..... (RE, 2002:67).

FIGURA 185_ Illustracăo tipográica, de Matthew Carte e Matt Eller, [.... Disponivel em: shttp://wwwe-arch-

.

IGURA 187 Caracteres alternativos [ ] Eigura produzida pelo autor

FIGURA 188_ Gilfo alternativo para o caractere 'W', '..... Figura produzida pelo autor:

FIGURA 189_ Marca composta por logotipo e simbolo, [...1. Disponivel em: hhttp://wwwwwalkerart.org/

FIGURA 190_Cartaz em ponto de onibus: Disponivivel em: shttp:///designarchives.aiga.org////entries/\%2Bi-

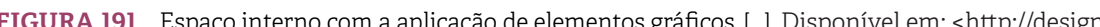

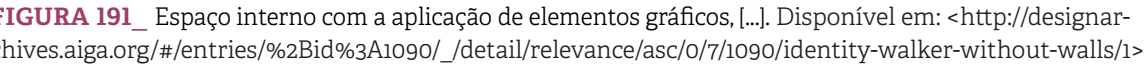
Acesso om: ol Fev. 2014

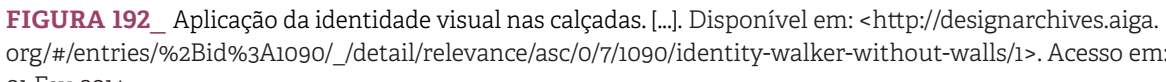
ol Fev. 2014

FIGURA 193_ O diagrama exemplifica como as tarjas. [...1. Disponível em: «https://www.youtube.com/ .

IGURA 194__Exemplos de construçăo das tarjas. I..... (HYLAND e KING, 2006:169]. FIGURA 195_Diagrama que demonstra a correspondência das teclas com os vocábulos. (HYLAND e

FIGURA 196_As tarjas são produzidas por 'caracteres gráicicos', [.... Disponivivel em: <https://wwwyyoutube FIGURA 197 O sistema visual das tarias ampliado'. [.]. (HYLAND e KING, 2006.177).

FIGURAS 198_ A versatilidade do sistema permite inúmeras aplicaçōes, [..... Disponivivel em: <https://www.

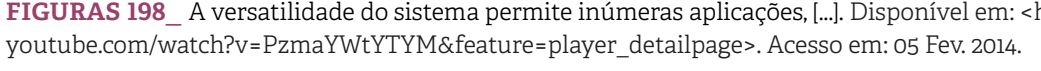

\subsection{PETROBRAS SANS, 2004}

EIGURA 199 Campanha publicitária, veiculada, [...]. Figura produzida pelo autor

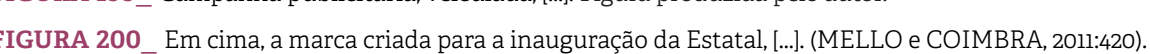
FIGURA 201_Prancha de apresentação do conceito para a identidade visual, [..... Disponivel em: < https://

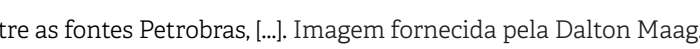

FIGURA 203_Provas impressas das 42 op̧̧öes desenvolvidas, [.... Imagem fornecida pela Dalton Maag FIGURA 204_À direita da página, as 34 opçōes descartadas I..... Imagem fornecida pela Dalton Maag. FIGURA 205 As oito opcōes selecionadas pela LED e Dalton, [.... Imagem fornecida pela Dalton Maag. EIGURA 206 Rota criativa 1 e suas quatro variaçōes, [..... Imagem fornecida pela Dalton Maas FIGURA 207_ Rota criativa ze suas duas variaçöes, ...... Imagem fornecida pela Dalton Maag IGURA 208_ Rota criativa z e sua opção únicica, ..... Imagem fornecida pela Dalton Maag. FIGURA 209_ Rota criativa 4 e suas duas opçōes, [..... Imagem fornecida pela Dalton Maag. FIGURA 210_A versão final apresentada pela primeira vez, [..... Imagem fornecida pela Dalton Maag. FIGURA 211__ Petrobras Sans Extra Bold Italic, com detalhes, (..... Imagem fornecida pela Dalton Maag FIGURA 212_Provas impressas para anotaçōes de correção, [...]. Imagem fornecida pela Dalton Maag. EIGURA 213_Amostra da família Petrobras Sans, [.... Figura produzida pelo autor.

FIGURA 214_ Petrobras Sans Bold destacada nas partes, [..... Figura produzida pelo autor. FIGURA 215_ Detalhe dos terminais curvos que afinam, [..... Figura produzida pelo autor.

EIGURA 216 Forma sugestiva dos acentos, vírgula, I..... Figura produzido pelo autor desta dissertaçāo

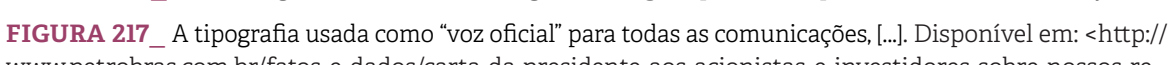
wwww.petrobras.com.br/fatos-e-dados/carta-da-preside
sultados-do-ltrimestre.htm>. Acesso em: 16 Fev. 2015 . . Acesso em: 12 Nov. 2014.

EIGURA 219_Peşa gráfica de campanha publicitariaia utilizando a fonte sobre fundos coloridos. Detalhe

\section{CONSIDERAÇÕES FINAIS}

FIGURA 220 Detalhes da fonte Univers comparada aos da Helvetica Neue. Figura produzida pelo autor 
SUMÁRIO INTRODUÇÃo

1. TIPOGRAFIA E IDENTIDADE

1 A TIPOGRAFIA CONSTRUINDO IDENTIDADES

1.2 OCORRÊNCIAS HISTÓRICAS

13 OS SISTEMAS DE IDENTIDADE VISUAL (SIV)

1.4 A TIPOGRAFIA EM SISTEMAS DE IDENTIDADE VISUAL

2. 0 CARÁTER DOS CARACTERES

2.1 AS CONEXÕES COM O TEMPO E A NACIONALIDADE

2.2 MEMÓRIA E A REAÇÃO EMOCIONAL Às FORMAS TIPOGRÁFICAS

2.3 PESOUISAS SOBRE OS "VALORES EMOCIONAIS" E "ATMOSFÉRICOS"

DA TIPOGRAFIA

2.4 A FACE DOS TIPOS E SUAS CONOTAÇÕES

3. TIPOGRAFIA CORPORATIVA PERSONALIZADA

3.1 DEFINIÇÕES

3.2 OS PRIMEIROS TIPOS CRIADOS PARA PROPÓSITOS ESPECíFICOS

3.3 EXCLUSIVIDADE OU PRATICIDADE

3.4 DESIGN TIPOGRÁFICO ORIGINAL E ALTERAÇÃO DE FONTE EXISTENTE

3.5 CUSTOMIZAÇÃO, MODIFICAÇÃO E COMPLEMENTAÇÃO

3.6 AVALIAÇÕES PRELIMINARES AO PROJETO

3.7 PROCEDIMENTOS GERAIS DE DESENVOLVIMENTO

DE UMA FONTE CUSTOMIZADA

Quadro I: Progressão do Desenvolvimento de uma Fonte Customizada
4. FONTES PERSONALIZADAS

EM SISTEMAS DE IDENTIDADE VISUAL

\subsection{RIJKSMUSEUM, 2012}

4.2 PARISINE, 1996

TIIAN E GUARDIAN SANS, 2005

4.4 YALE, 2004

4.6 PETROBRAS SANS, 2012

5. CONSIDERAÇõES FINAIS

6. REFERÊNCIAS BIBLIOGRÁFICAS

7. GLOSSÁRIO VISUAL

8. ANEXOS

ANEXO I: Matthew Carte

ANEXO II: Fabio Haag e Fernando Caro, Dalton Maag, Brasil 
INTRODUÇÃO Além dos aspectos intrínsecos ligados ao universo da tipografia como legibilidade, estilo e funcionalidade, a questão expressiva da tipografia tem sido pesquisada desde o início do século xx para tentar responder, do modo mais objetivo possível, quais os atributos que fazem determinado design tipográfico estabelecerem uma relação de reconhecimento, aproximação e identificação entre os tipos e a mensagem? Compreender como as estruturas formais das tipografias desencadeiam reações emotivas no leitor pode significar um ganho substancial na eficiência da comunicação visual dependente ou baseada no texto. Àquela pergunta, pode juntar-se uma outra: em que medida 20 uma fonte usada exclusivamente por uma instituição pode conduzir a mensagem corporativa e adquirir a posição de marca, incorporando plenamente a função identitária de reconhecimento?

A compreensão da dinâmica que as formas de um design tipográfico podem assumir, denotando sua função de comunicar e conotar significados expressivos, emocionais ou retóricos, é um domínio almejado pelos designers de tipos, pois é a partir desse elemento que uma comunicação pode conquistar níveis maiores de eficiência.

Quando se trata de um tipo considerado display, ou seja, tipos com design apropriado para títulos em tamanhos grandes, ou de fontes "fantasia", com suas características estilísticas ou ornamentais mais evidentes, atribuir e identificar uma clara característica expressiva é uma tarefa menos complicada, pois as referências visuais desse tipo de fonte geralmente são mais evidentes em suas formas. Esses casos são muito úteis na concepção de logotipos e letreiramentos, que aceitam perfeitamente leituras menos convencionais. Mas as fontes de texto, tipos projetados para leituras longas, em corpos menores, que não podem ol chamar a atenção para si e cujo fator de legibilidade deve ser alto, necessitam obedecer a critérios mais rigorosos e tornam a tarefa de personalização e atribuição de caráter mais complexo e extremamente sutil.

O objeto deste estudo são as tipografias customizadas - fontes

05 personalizadas ou criadas exclusivamente - para o setor corporativo pois esse ambiente proporciona uma ampla utilização da tipografia em diferentes mídias em vários níveis de complexidade, portanto é um campo rico para análises de desempenho de uma fonte com relação à sua capacidade de estabelecer uma identidade. Essa propriedade, atribuída

- à tipografia, é especialmente requerida nos dias atuais em que a comunicação flui por canais cada vez mais diversos, gerando um acúmulo midiático em que novos suportes são constantemente agregados aos já existentes. Como essas mídias nem sempre compartilham uma estrutura minimamente compatível, é comum ocorrerem variações consideráveis

15 no aspecto das mensagens, fator decisivo para a manutenção de uma coesão visual e discursiva. Uma vez que a tipografia é a forma visual da linguagem verbal, o aspecto e a configuração desta forma visual influenciam diretamente a maneira como essa linguagem é percebida. Contudo, tal determinação não deve ou precisa afetar o conteúdo objetivo

20 da mensagem, mas pode reunir condições para uma comunicação mais ativa e dinâmica. Portanto, esta pesquisa não contempla projetos de identidade que utilizam fontes comerciais disponíveis abertamente, pois elas não possuem as características de exclusividade necessárias para a criação de um vínculo único com o sistema de comunicação.

Os Sistemas de Identidades Visuais, em sua maioria, utilizam fontes chamadas de "apoio" ou "secundárias" (tipos que acompanham e/ ou contrastam com o logotipo, usados em toda a comunicação textual) selecionadas do imenso universo de opções comerciais disponíveis. Por razões práticas, que incluem conceitos de legibilidade e leiturabilidade

esse universo é drasticamente reduzido a algumas dezenas de tipos que desempenham adequadamente essa função. É inevitável, portanto, que ocorra uma diluição da força comunicativa pela repetição de fontes e a ausência de um componente expressivo em particular. O impulso criativo por designs originais é citado pelo designer tipográfico holandês Gerard

35 Unger em seu livro While You're Reading. Ao referir-se ao desgaste que os tipos sofrem com a super exposição, explica que uma das razões para a demanda por novas fontes é que aquelas mais antigas e confiáveis são 
vistas com muita frequência, o que as torna muito familiares, perdendo o1 as qualiades de novidade que já tiveram, não sendo mais capazes de surpeender (UNGER, 2007:116). Esse "fator surpresa" também pode ser interpretado como "fator de identidade", algo como uma personalidade única, expressiva e individual que representa um objeto-ideia, empresa, 05 instituição, grupo, cultura, país etc.

Atualmente, a produção de fontes tipográficas atinge altos níveis em termos quantitativos e, principalmente, em qualidade criativa e técnica. Softwares de design e aplicativos secundários de edição e produção de fontes são muito acessíveis e permitem aos designers um alto grau de refinamento formal e vasto campo para a criatividade. Um contraponto à oferta de designs de qualidade é a pequena exploração dessa produção por parte dos responsáveis pela comunicação impressa e digital que usam informações textuais de forma contundente limitando-se ao uso indiscriminado, e por vezes, negligente, de tipos massificados, desgastados e destituídos de qualquer componente que agregue personalidade ou que reforce o conteúdo específico da sua comunicação. São escolhas que não consideram a influência decisiva do design tipográfico como condutor de uma "mensagem invisível", que estabelece conexões básicas, diretas e permanentes com o leitor.

ara construir um repertório conceitual consistente, um vocabulário adequado e uma linha de raciocínio apropriada para o estudo de casos de fontes digitais personalizadas, três conteúdos são tratados sob o ponto de vista da criação e uso de tipografias como importante fator identitário.

O primeiro capítulo é dedicado á capacidade dos tipos de constru- 25 irem indentidades e à compreensão de seu aspecto, sintaxe estrutural e recorrência de seu uso como resultantes diretos de um ambiente histórico-sociocultural que determinam padrões visuais gráficos. Aborda as questões do legado e da tradição tipográfica como configuradores de identidades pela incorporação de elementos da cultura local. é pontuado 30 por exemplos históricos em que o design de um conjunto de letras ou de tipos representou valores ideológicos, institucionais e morais, de modo sistemático e consciente. A sistematização da comunicação visual tratada com ênfase na tipografia, projetada com exclusividade para atuar dentro de um código visual articulado, ou nos programas de identidade corporativa e nos manuais de estilo da marca, ou brand books. o1 O segundo capítulo explora as características visuais da tipografia que aumentam a capacidade de sua memorização e criam associações a temas comuns e respostas emocionais no leitor. Essas relações têm sido pesquisadas e testadas desde o início do século passado, buscando

05 qualificar e quantificar as características emocionais dos tipos. Confirmam a ideia de que estes, além de sua função mais literal de transmitir sua mensagem, também são carregados de caráter expressivo, que geram conotações e comunicam uma atmosfera.

O terceiro capítulo ocupa-se em definir e classificar as tipografias

o projetadas exclusivamente para instituições, compreendendo mais precisamente como a personalização de um design tipográfico contribui paraa consolidação de um sistema de identidade visual. Um projeto personalizado pode ser obtido de várias maneiras, desde um design customizado totalmente original até modificações ou complementações 15 de tipografias já existentes.

Esta parte ainda destina atenção especial para os procedimentos mais comuns, adotados por type foundries, ao desenvolverem fontes customizadas corporativas, desde as informações conceituais fornecidas pelo contratante, as avaliações inicias feitas pelo designer, os primeiros 20 esboços e todo o fluxo de produção criativa e técnica da fonte.

Finalizando a série de capítulos, o quarto discorre sobre seis tipografias personalizadas que desempenharam, ou ainda desempenham, papéis fundamentais nas identidades visuais que representam. Os projetos são diversificados, mas, em todos os casos, a fonte ocupa a função primordial

25 de identificar a instituição, podendo incorporar, ou até mesmo substituir, a função da marca. As fontes são a Rijksmuseum, de Paul van der Laan, para o Museu Nacional em Amsterdam; a Parisine, de Jean François Porchez para o sistema de transportes de Paris; a família tipográfica Guardian, de Christian Schwartz e Paul Barnes, para o jornal inglês The Guardian;

30 Yale, de Matthew Carter, para a universidade de Yale; a Walker, do mesmo designer, para o Walker Art Center; e a Petrobras Sans, criada pela equipe brasileira da Dalton Maag, para a estatal petrolífera do país.

Este estudo visa, sobretudo, contribuir com a área profissional envolvida nos processos da comunicação visual e com o reconhecimento 35 da relevância de uma tipografia personalizada e adequada ao propósito de constituir uma identidade visual consistente. 


\section{TIPOGRAFIA E IDENTIDADE}

A história da humanidade está intimamente conectada ao registro do pensamento por meio de sinais sonoros, verbais, pictóricos e gráficos, e em particular a escrita. Essa invenção, como um instrumento sistematizado de armazenamento de informações eficiente, amplifica as possibilidades

da comunicação, da conservação da memória histórica e da própria educação (GRAVIER, 2013:65). Do mesmo modo que a escrita representou um papel determinante para a preservação da memória coletiva quando a prática oral já não era suficiente para de desempenhar esse papel (LEROI-GOURHAN 1984:60), a sistematização e mecanização do processo de escrever — a tipo-

15 grafia - logo assumiram função de destaque na construção de repertório culturais, regionais ou globais. A gestualidade da escrita caligráfica imprime a marca da personalidade de quem a executa e, consequentemente a marca da cultura a que pertence. A tipografia, assim como a escrita é parte da individualidade de determinadas sociedades e de alguma maneira

20 reflete a imagem das respectivas culturas, desde que essa cultura a tome como própria e se identifique com a tipografia (MANDEL, 2006:18). Apontando para o caráter emblemático da tipografia e seu papel humanista, Ladislas Mandel acredita que "uma letra não passa de um som, seu traçado é a marca do homem" (Ibid.:14), defendendo que as mutações da escrita correspon-

25 dem sempre às mutações do espírito, em cada época e cada lugar. "A escrita, além de memória da humanidade, é o seu espelho, é a expressão direta do homem e da sociedade" (Ibid.:11). No mesmo sentido, o designer e tipógrafo alemão Otl Aicher valoriza a carga persuasiva da forma da escrita ao observar que a letra é um signo de um som e que, por meio de seu estilo visual

30 pode transmitir ou estabelecer relações mais particulares e contundentes "A escrita, assim como a língua, tem formas retóricas e expressões. Entretanto, devemos diferenciar a escrita que busca produzir diversas formas de conteúdo da escrita que se esforça para produzir diversas formas de articulação" (AICHER, 2004:110 — tradução minha').

$35-1$ "la escritura al igual que la lengua tien formas retóricas y expresiones. Sin embargo, debemos diferenciar entre la escritura que busca producir diversas formas de contenido y la escritura que se esfuerza por producir diversas formas de articulación." (AICHER, 2004:110). 
Personagem ideológico em conflitos de conquista e subjugação, o idioma e sua forma escrita foram, e ainda são, usados nos momentos críticos da dominação moral ou da independência de povos, desencadeando debates sobre identidade e afirmação cultural. O idioma é um dos pilares da identidade cultural e configura-se quando há a noção de pertencimento os e de delimitação, em que se identificam características comuns e são compartilhados os mesmos códigos, em um mesmo tempo e lugar, ou seja, seu conceito é oposto à diversidade, à diferença. Corresponde a uma necessidade humana universal de fazer parte de um todo maior e contínuo: é a vontade de memória ou desejo de perpetuação (John Locke apud RICOEUR, 2007:114; NORA, 1993). Esse processo ocorre quando os elementos simbólicos mais característicos de um grupo são reconhecidos e repercutem entre os indivíduos desse grupo ou território, especialmente pelo uso contínuo e organizado de formas constantes.

1.1 A TIPOGRAFIA CONSTRUINDO IDENTIDADES_ Como em qualquer estudo que envolva a expressão da cultura, a forma visua da linguagem oral, desde a escrita cuneiforme praticada pelos sumérios (aproximadamente 4.000 a.C.), passando pela caligrafia da Europa ocidental, essencialmente manual da Idade Média, até a tipografia digi- 20 tal que utiliza os meios computacionais para sua produção e uso, é uma expressão cultural que constitui um campo transdisciplinar e interdisciplinar, inevitavelmente atrelada a relações antropológicas mais amplas, comprometidas com as atividades artísticas, costumes e crenças, e aos sistemas de comunicação desenvolvidos por determinadas sociedades em certos espaço e tempo. Se a música é legitimamente encarada como uma produção cultural, resultado de uma dada cultura (viLLAS-BOAS, 2009:18-19), a tipografia pode ser compreendida de modo semelhante, ou seja, seu aspecto, sintaxe estrutural e a recorrência do uso de determinados tipos, são frutos diretos de um ambiente histórico-sociocultural e precisam ser observadas dentro dessas relações (MANDEL, 2006, passim). Em alguns casos, ocorrem associações com a ideia de poder valor, quando o imaginário de um grupo se apropria de valores estéticos de uma cultura dominante. Assim como no design em suas manifestações mais amplas, o design de caracteres tipográficos de um mesmo idioma é um elemento de construção simbólica do contexto espećifico ao qual pertence: na mesma medida que é reflexo e integrante de uma conjuntura, também atua como um agente delimitador do padrão visual gráfico do momento.

Tecendo um paralelo com a comunicação visual que começa a se constituir no final do século xix, Villas-Boas traz uma definição pragmática:

O designgráfico, tal como o conhecemos, é uma atividade expressamente comunicacional que nasce da necessidade de, num ambiente de massas, associar valores simbólicos a determinados bens, sejam estes concretos ou não. Para tal, lança mão de um instrumental simbólico que se expressa materialmente no plano da visualidade, de forma a veicular estes valores mediante a preservação deste mesmo caráter simbólico (VILLAS-BOAS, 2009:21).

Desde as primeiras configurações dos tipos móveis, ainda baseados diretamente em traços caligráficos, o desenho das letras já estava vincu5 lado às características idiomáticas de cada país ou região, preservando sutilezas de entonações ou pronúncia. A forma das letras e o design dos tipos estão em constante sintonia com as dimensões culturais (locais ou regionais), refletindo-as ou representando-as, auxiliando a construir um tecido simbólico permanente e incorporado à dinâmica social: "[...] que

20 faz o typedesigner posicionar-se em constante estado de observação das relações humanas, nas interações afetivas estabelecidas com o mundo físico e social ao seu redor, a partir das plataformas sociais de comunicação" (CONSOLO, 2013:108).

Abordando as questões do legado e da tradição tipográfica como configuradores de identidades pela incorporação de elementos da cultura local, a designer Priscila Farias aponta que "a linguagem verbal escrita é um importante veículo para a cultura e a identidade. Trata-se de uma linguagem com múltipla articulação, que conecta conceitos, expressão sonora e expressão visual" (FARIAS, 2011:166). Ouando as estruturas e a aparência

30 dos caracteres se definem, sendo produzidas e difundidas de forma sistemática e controlada pelos meios de impressão, consolidam significados comuns que e relacionam-se com o universo da cultura visual do grupo ao qual estão vinculados. Naturalmente, aqueles grupos dotados de maior eficiência na fabricação e distribuição de tipos (e seu design) têm mais

35 chances de impor seus modelos a outros grupos e influenciar a cultura destes. Segundo Farias (2011) esse foi o caso da conformação do gosto holandês, influenciado pelas matrizes de tipos franceses no século XVI, 
que influenciaram o gosto britânico do século xvir e que se disseminou na América do norte, incluindo os tipos vernaculares ingleses do século XIX. No final desse período einício do século seguinte, a unificação de pequenos impressores dos Estados Unidos em torno de uma única associação, a Americam Type Founders (ATF), passa a disseminar os tipos daquele país 05 em escala internacional (FARIAS:164-165).

Contudo, tentar construir uma identidade mais abrangente como identidade de uma nação pressupõe o cerceamento da diversidade que é inerente a qualquer agrupamento cultural. O caráter projetual do design, assim como o design tipográfico, exige atenção às demandas de quem o solicita, do que precisa comunicar e a quem deve se dirigir. Se a elaboração de discursos específicos for intrínseca ao design, como criar, então, ferramentas de expressão gráficas singulares que não restrinjam a linguagem?

A afirmação de Villas-Boas de que "nos projetos de design, os elementos compositivos não têm como ser instrumentalizados dessa forma, sob pena de prejudicarem a própria composição e o objetivo comunicacional que a gerou (VILLAS-BOAS, 2009:78), indica que recursos de linguagem de ordem estética ou conceitual, quando submetidos ao design, contrariam a sua natureza comunicativa diversa e abrangente. Mas não se pode negar que os elementos da linguagem visual são impregnados pela simbo- 20 logia construída em determinada cultura. A tipografia observada pelo prisma da história é exemplo disso, e no ambiente social ou corporativo é imbuída da função de refletir a identidade de ações ou produtos, participando do processo de assimilação e memorização do público pelo hábito:

Embora uma tipografia possa ser fundamental para determinar o aspecto de uma revista e contribuir para a criação de uma imagem para uma organização ou empresa, em tais casos os tipos são frequentemente escolhidos não pelas suas qualidades emocionais, mas pelo fato de poderem diferenciar revistas, organizaçōes, empresas ou o que for, de todos os outros (UNGER, 2007:143 - tradução minha²).

Aspectos culturais, econômicos, políticos e antropológicos são apenas algumas das variantes que atuam na formação de uma identidade e,

2 "Although a typeface may be instrumental in determining the look of a magazine, and can contribute to the creation of animage for an organization or company, in such cases types are often chosen less for their emotional qualities than for the fact that they can make the magazine, organization, company or whatever look different from all others" (UNGER, 2007:143]. como são elementos sujeitos a transformaç̃es, não são inteiramente credenciados para estabelecer um paradigma absoluto. Frente ao ritmo de inovações dos tempos correntes e a exposição constante e massiva de diversas culturas - uma época multicultural — a realidade torna-se

05 obsoleta rapidamente e abre espaços para identidades flexíveis e fluídas O sociólogo Zygmunt Bauman (2005:21) é contrário à ideia de identidade como algo prédefinido, fixo e duradouro, ou seja, um ponto de referência constante que possa ser referenciado e interpretado facilmente, afirmando que “[...] a 'identidade' só nos é revelada como algo a ser inventado, e 10 não descoberto; como alvo de um esforço, 'um objetivo'; como uma coisa que ainda se precisa construir a partir do zero [...]" (BAUMAN, 2005:21), não é um segredo escondido, um truque visual, mas algo que deve ser criado ou, na linguagem do design, projetado (BONSIEPE, 2011:50). Essa afirmação se revelará presente nas atitudes de designers tipográficos em projetos

is estudados mais adiante.

1.2 OCORRÊNCIAS HISTÓRICAS_A história é permeada de exemplos em que os desenhos de letras e tipos representam valores ideológicos, institucionais e morais de modo sistemático e consciente. Um mode20 lo de quase dois mil anos, cujas formas permanecem eficientes até os dias de hoje sob a forma de tipos digitais, são as antigas letras romanas no modelo conhecido como Capitalis Monumentalis, um design que começou a se desenvolver por volta de 800 a.C., quando os alfabetos Grego Antigo e Etrusco foram assimilados para formar o alfa-

25 beto latino que conhecemos hoje. Para Baines e Haslam (2002:41), sua expressão "mais celebrada" pode ser extraída da base da Coluna de Trajano, gravada em Roma entre os anos 113 e 114 d.C. (FIGURA 001)

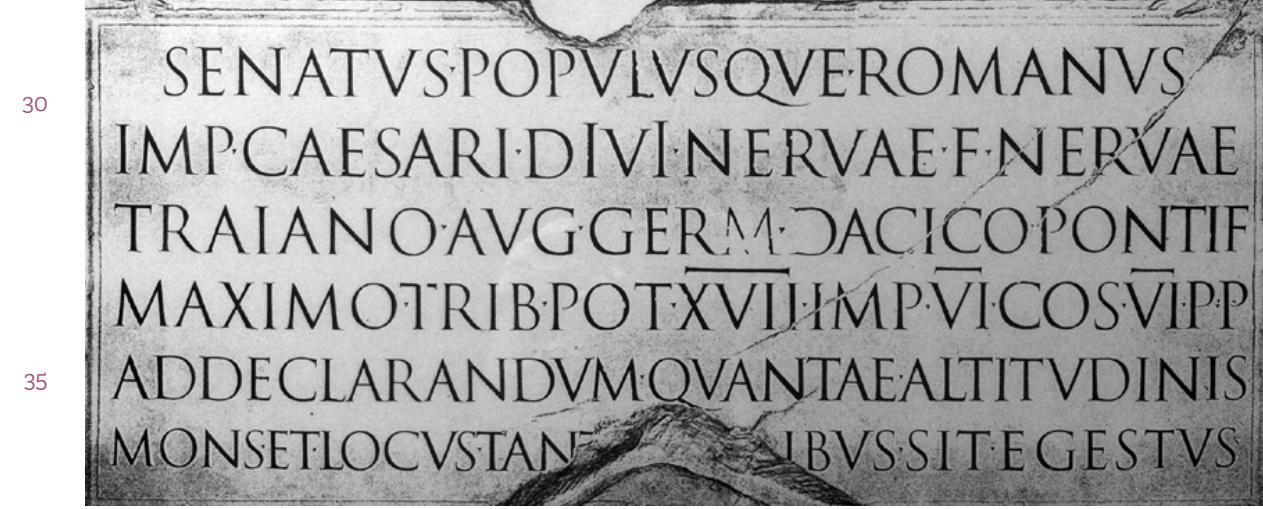

FIGURA 001_Inscrição na base da Coluna de Trajano, em Roma com a capitular romana. 
O conjunto de 21 letras maiúsculas é um design de elegância e precisão sem precedentes, como afirma Paulo Heitlinger (2006:17), "a letra latina, que herdara sua forma dos alfabetos gregos e fenícios, assume uma forma perfeita, sublime, na época dos imperadores romanos Augusto, Nerva e Trajano" e esconde uma malha matematicamente construída para distribuir os traços e estabelecer proporções (Ibid.:33). Segundo Nicolete Gray (1986:15-28), a inscrição na Coluna de Trajano é o primeiro exemplar de inscrição romana a instituir a modulação entre traços finos e grossos (contraste), acentuar o eixo humanístico nas curvas e a consolidar as serifas como acabamento das extremidades das hastes (GRAY, 1986:15-28). Tanto o desenho das letras quanto o sistema alfabético conciso e eficiente para representar verbalmente o idioma vigente foram instrumentos eficazes para sinalizar, conduzir e resguardar o avanço imperial romano marcando, com o estilo inconfundível, cada via, monumento, estandarte ou documento. Devido ao seu emprego constante e organizado na sociedade romana da época, pode ser considerado, informalmente, o primeiro sistema de identidade visual e, nesse caso, de toda uma cultura.

Outro caso historicamente relevante por representar uma mudan-

jet de ce médaille le de l'E FIGURA 002_Detalhe de página do livro Médailles sur les principaux evenements du regne com o tipo Romain du Roi. ça radical na concepção das formas dos tipos, que segundo o tipógrafo Fred Smeijer (2003: 20) é considerada pela literatura o primeiro projeto tipográfico, é a Romain du Roi ou a Romana do Rei, uma tipografia criada para uso exclusivo do rei Luís xIv (1638-1715) que governou a França de 1643 a 1715, em pleno vigor dos ideais iluministas (FIGURA 002).

Antes dos iluministas, os tipógrafos humanistas do século xv como o italiano Felice Feliciano, o alemão Albrecht Dürer e o francês Geofroy Tory apoiavam-se nos traçados caligráficos e em todas as sutilezas e variedades estruturais que tal abordagem implica. No decorrer do século seguinte, os tipógrafos passaram a construir os tipos de base romana a partir de ferramentas vindas da geometria. Os tipos não se referiam mais aos ideais canônicos de proporção, em vez disso, foram reinterpretados como uma "coleção de elementos linguísticos" quase modularizados, um sistema de opostos como grosso/ fino, vertical/horizontal, haste/ serifa. "Esta tipografia moderna substituiu o idealismo pelo relativismo" (MILLER; LUPTON, 1994:22). Para a nova e exclusiva tipografia, o rei francês movimentou um considerável comitê composto por notáveis de diversas áreas do conhecimento científico e das artes. O projeto tipográfico da
Romain du Roi teve início em 1692 e sua primeira etapa concluída em 1702. Foi supervisionado pelo Commité Bignon da Académie des Sciences sob a coordenação do erudito e tipógrafo Jacques Jaugeon (DODD, 2006:44 HEITLINGER, 2006:96; MORISON, 1997:22). Nesse projeto, os desenhos ou

05 imagens das letras partiram de uma abordagem racionalista e abstrat (FIGURA 003) e desconectada dos processos de produção vigentes, uma tentativa de se afastar a criação das imperfeições que o trabalho manual que o cortador de tipos (punchcutter) fatalmente infundia em seus tipos. Tinha como base uma grade principal dividida em partes iguais e por

grades secundárias, possibilitando uma padronização bastante objetiva que servia de guia para o trabalho dos tipógrafos. Mesmo o desenho das letras itálicas, antes completamente baseado na caligrafia, fo projetado dentro da mesma grade, que apenas fora inclinada. A premissa fundamental desse projeto foi o racionalismo extremo, concretizado na

geometrização da construção dos tipos levada ao rigor máximo (LAWSON 1990:175), resultando, inicialmente, em estruturas pouco flexíveis à anatomia e funcionalidade que uma tipografia deve conter (SMEIJERS, 2003: 20). Esse predomínio obstinado da razão pura rompeu com a tradição humanista que se apoiava essencialmente na caligrafia como meio de forma-

20 ção dos traços e remates das letras. Esse projeto ideal em tipos móveis para impressão foi executada por Philippe Grandjean, trabalho iniciado em 1693, que flexibilizou parte da rigidez inexequível, tanto pela revisão de inconsistências geradas por uma geometria excessiva que não dialogavam com a fluidez da tipografia, como pelas próprias limitações da

gravação das letras em tamanhos muito reduzidos, o que, naturalmente impele à eliminação de exageros e correção dos desvios de percepção visual (Ibid..21). De acordo com Dodd (2006:45), o resultado desse trabaho, que levou mais de 80 anos para ser completamente implementado e concluído apenas por volta de 1745, foi a tipografia oficial francesa

empregada nos impressos produzidos pela imprensa nacional e pelos Imprimeurs du Roi durante o século xviI até o surgimento dos tipos produzidos pela família Didot, cujo caráter racional foi levado ainda mais adiante.

Historicamente, o mecanismo, organização, estrutura e desenho dos registros visuais da linguagem humana estão intimamente entrelaçados com os hábitos corriqueiros e com a cultura de um povo. Portanto, se a Romain du Roi não pôde ser ela própria um veículo da identidade

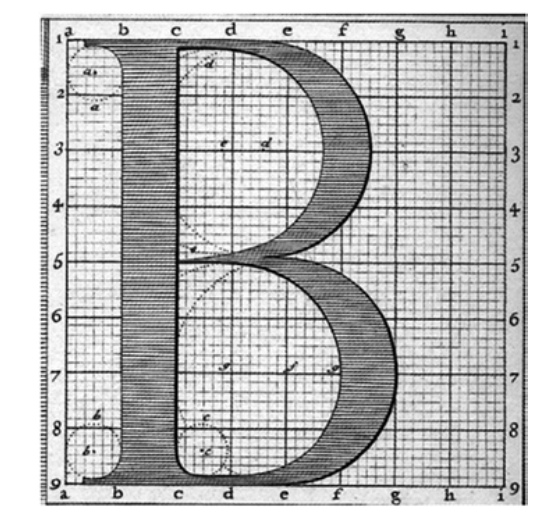

FIGURA 003 Gravura, provavelmente de autoria de Louis Simonneau, do modelo para os tipos cortados por Phillipe Grandjean. 
francesa do século XviII, o sentido inovador de sua abordagem na construção das formas das letras e a proposta conceitual racionalista explícita vazaram do fechado círculo real e, rapidamente, difundiram-se por toda a Europa.

\section{Bueignung.}

3hr naht euch wieber, fohwanfende Bejtalten, Die früh fid) einjt bem trïben Bliaf gezeigt. Berjuth' id molhl, eutd biesmal feitzubalten?

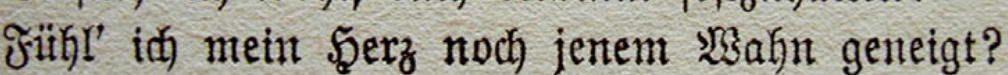

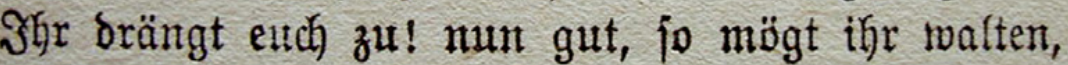
Wie ihr aus Dumft uno Rebel um mich fteigt; Diein Bujen füflt fich jugendichl ericjüttert

Bom Bauberhauch, ber euren Bug untwittert.

FIGURA 004_Detalhe do tipo Fraktur em página

do livro Fausto, de Goethe,

em uma edição de 1920.

à bíblia germânica de Lutero (1522) e em que pequenos estados de fala germânica, Bavária e Württemberg consolidaram-se. Comissionado pelo imperador Maximiliano I (1513), o 20 estilo gótico Fraktur é tido como puramente alemão (FIGURA 004). De acordo com os autores, a oposição entre o catolicismo romano e o protestantismo luterano era sinalizada pelo estilo da escrita, independentemente do que estava escrito. Sempre que o recém-formado estado alemão entrava em conflitos geopolíticos, as letras em estilo Fraktur era

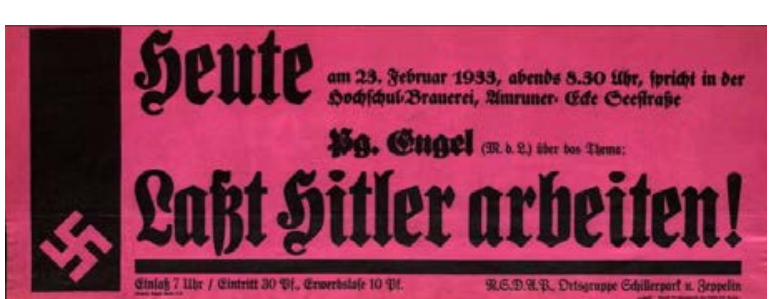
politizada como um "tipo alemão". Isso ocorreu na Guerr Franco-Prussiana, na Primeira Guerra Mundial do regime nazista vigente na Segunda Guerra Mundial (BAIN e SHAW 1998:40). Adolf Hitler, alçado ao poder em 1933, a tomou como tipografia oficial (FIGURA 005), uma forma de resgatar e reafirmar a cultura germânica ancestral aproveitando o

FIGURA 005_Cartaz que anuncia encontro nazista em Berlim, em 1933, utiliza a Fraktur como tipografia oficial. sentido austero, denso e impositivo dessas letras como reforço de suas mensagens ideológicas.

Na direção oposta, os princípios da Nova Tipografia definidos pelo designer e tipógrafo alemão Jan Tschichold em 1925, em concordância com as diretrizes da Bauhaus, estabeleceram os parâmetros básicos para o design diagramado em uma malha construtiva assimétrica e o uso de uma tipografia sem serifas, estruturada racionalmente com base na geometri elementar (MEGGS e PURVIS, 2009:415). Em sequência, o International Style da Escola Suíça (1950-1980) e sua suposta "neutralidade" com tipos grotesque (sem serifas e sem contrastes) como a Helvetica e Univers, causaram

5 impacto profundo na comunicação publicitária, massificando e nivelando o conteúdo visual do texto e suas implicações nas especificidades da mensagem para públicos distintos (Ibid.462-465). O credo funcionalista que pregava a objetividade, clareza e simplicidade, norteou e nivelou a aparência do design em escala global (MIDDENDORP, 2004:10). Essa padronização visual - que também serviu aos desígnios da expansão capitalista do pós-guerra, atualmente já é percebida como pertencente a um período determinado apesar de manter a sua eficiência comunicativa nos dias de hoje.

Em uma esfera mais próxima da construção cotidiana de identidades localizadas, o uso de uma determinada tipografia pode assumir a condição 15 privilegiada de um logotipo como força identificadora. Na indústria editorial ou jornalística, capas e páginas de conteúdo mantêm a coerência da identidade por meio dos tipos exclusivos. É o caso, por exemplo, da revista argentina tpG editada pelo designer e tipógrafo argentino Rubén Fontana. Além do logotipo formado exclusivamente pela fonte, todos os fascículos 20 da publicação foram compostos com sua tipografia Fontana ND (FIGURA 006), uma fonte sem serifas neogrotesca humanística com particularidades evidentes nos remates das hastes do ' $\mathrm{f} l \mathrm{l}$ t $\mathrm{x}$ ' eno uso de parênteses itálicos, mesmo nos textos em romano. Isso faz a revista ser reconhecida imediatamente por sua tipografia. É comparada à fonte FF Meta de Erik Spiekermann

25 mas com uma personalidade própria, como sinaliza Fred Smeijers:

Fontana [...] percorre o caminho aberto pela Meta. Fontana é muito descomplicada, très sympatique, iluminada e receptiva; ao mesmo tempo ainda é séria o suficiente para compor longos trechos de texto e, de algum modo, se mistura bem com ilustraçōes. É adequd para o trabalho diário e, embora lembre muito outras tipografias, o caráter geral é forte o suficiente para que ela seja vista como ela é (SMEIJERS, 2003: 40 - tradução minhaª).

But Fontana is not at all a Meta remake. It proudly travels fu Fontana is very uncomplicated, très sympatique, sunny, and open-minded; at the same time it is st $/$ serious enough to set long passages of text in, and somehow it mingles well with illustrations. It is suitab for daily work, and although it has some strong resemblances to other typefaces, the character of the whole is strong to let it be seen as its own thing" (SMEIJERS, 2003:40) 
A partir da edição n 55 , a revista incorporou outra fonte de Fontana, ol a serifada Andralis, proporcionando um contraste equilibrado e uma nova textura tipográfica às páginas.

1.3 OS SISTEMAS DE IDENTIDADE VISUAL (SIV)_ As primeiras manifestações de identificação por meio de monogramas ou inscrições surgem nas edificações gregas micênicas e egípcias antigas. Segundo Juan Costa (2011:38), o registro com propósitos comerciais de marcas em ânforas de vinho, azeite ou mel remontam ao século xIv a.C., onde já se encontram noções próximas às funções de marcar selar ou assinar, assim como valores de identidade, autenticidade e garantia (COSTA, 2011:36). O hábito de marcar bens da produção da cultura agrária ou de manufaturados se desenvolveu por pura necessidade de registar a procedência autoria e propriedade desses bens e dessa forma primária permaneceu até o início do século xx d.C. A marca, o nome do fabricante ou o sinal gráfico que o representava, era simplesmente marcada sobre o próprio produto ou no seu invólucro. Pode-se afirmar que a primeira sistematização de símbolos identificadores ocorreu com a heráldica medieval quando famílias, agremiações de artesãos e militares passaram a utilizar códigos simbólicos para escudos e brasões configurando um verdadeiro sistema de identificação e reconhecimento (COSTA, 2011:48). Os principais elementos desse código eram pictogramas (cruzes, flores, animais, armas, etc.) e cores, cuja articulação indicava origens, propriedades, posição social e uniões familiares. Algumas empresas conservam até hoje resquícios desse sistema heráldico, como nas marcas das montadoras de automóvel Peugeot, BMw e Alfa Romeo, por exemplo. Desde o período renascentista impressores possuíam uma marca própria que rubricava seus livros e praticamente todo comerciante de alguma relevância tinha um selo ou marca registrada. Philip B. Meggs e Alston W. Purvis (2009) apontam para um marco em que o empreendedorismo moderno, que começou a 30 tomar forma nas primeiras décadas do século xx, requeria um controle maior de sua imagem pública, e uma sistematização:

A Revolução Industrial, com sua fabricação e comercialização em massa, aumentou o valor e a importância de marcas registradas para 35 identificação visual. Porém, os sistemas de identidade visual que surgiram nos anos 1950 iam muito além das marcas ou dos símbolos.
O âmbito nacional e multinacional de muitas corporaçōes dificultava que elas mantivessem uma imagem coesa, mas, ao unificar de modo coerente todas as comunicações de uma dada empresa tal imagem podia ser projetada, e o design foi convocado para ajudar a alcançar objetivos específicos dessas organizaçōes (MEGGS e PURVIS, 2009:523).

1.3.1 As rupturas estéticas do início do século xx As primeiras décadas do século $\mathrm{xx}$ foram férteis para movimentos artísticos que que se opunham ao subjetivismo nas expressões artísticas, eliminando 1. qualquer elemento gráfico que delatasse algum sentimento. $O$ construtivismo russo (1912), o De Stijl (1917), a Bauhaus (1919) e o Mechano-Fraktur na Polônia (1924) prepararam o terreno conceitual de um design modernista construtivo, objetivo, racional e funcional. O uso da tipografia e

a malha de diagramação também tiveram um momento de ruptura e de consolidação registrado nas publicações Tipografia Elementar (1925) e A Nova Tipografia (1928), do 20 tipógrafo edesigner de livros alemão Jan Tschichold. Ele pregava uma nova cultura visual em que todo material impresso, além de ser composto com tipos sem serifa

deveria dizer o absolutamente necessário de forma clara e ordenada, utilizando para isso a malha ortogonal, a distribuição assimé-

trica dos elementos, a preservação de espaços em branco e o contraste

entre as massas de texto. (MEGGS, 2009:415-417) (FIGURA 007).

Após a consolidação da noção de mercado, desenvolvida durante a Revolução Industrial e posteriormente aprimorada pela publicidade e marketing, o design gráfico nesse início do século xx começa a delimitar seu campo como um meio estratégico para a indústria, agindo nos

5 pro-cessos de fabricação, uso e apresentação daquilo que era produzido. No âmbito da comunicação visual, o design ocupa esse campo de form mais organizada e, de acordo com Müller-Brockmann (2005), o design
FIGURA 007_Convite para conferência, design de Jan Tschichold, 1927. A tipografia foi a responsável por grandes mudanças a favor do design ernista. Tschichold acreditava que as regras antigas da tipografi contrariavam a adequação da

composição ao seu proposito real. Formulou em 1928 os princípios da assimetria no Die Neue Typographie (a Nova Tipografia). 


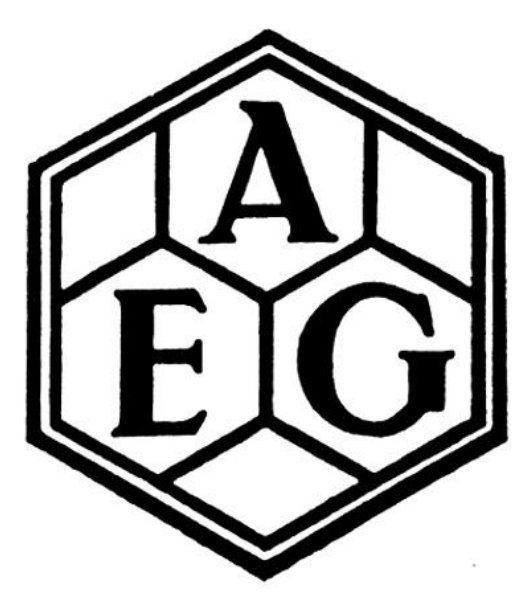

EIGURA 008_Marca desenhada por Peter Behrens em 1907, formado por tres hexagonos quecontem us un hexagonomalor. A marca foi sistematicamente aplicada em materiais gráficos e em produtos
da AEG
[ ] engloba todas as modalidades de informação visual : material impresso, anúncios para a imprensa, folhetos, catálogos, livros, jornais, revistas, embalagens, logotipos, marcas comerciais,

cartazes, exposiçōes, gráficos para o cinema e televisão, programas audiovisuais, sistemas de signos, ilustraçōes científicas, indicadores de aparatos e máquinas e o design corporativo

(MÜLLER-BROCKMANN, 2005:9 - tradução minha4).

As bases dessa nova linguagem gráfica foram essenciais para a sistematização da comunicação visual.

Segundo Meggs e Purvis (2009:298) e Hollis (2001:25), a primeira forma documentada de um Sistema de Identidade Visual (siv) baseado em uma marca, uma família tipográfica e em layout com elementos e formatos padronizados teria sido aquele projetado para a indústria alemã de turbinas e energia AEG (Allgemeine Elektricitäts-Gesellschaft). Isso teria ocorrido no mesmo momento em que a produção industrial se transformava com as primeiras linhas de produção em sequência e com a necessidade de se organizar visualmente em um cenário midiático cada vez mais diversifcado. Os dirigentes da AEG perceberam a urgência em formar uma cultura sólida da empresa criando uma imagem pública da marca. Para Hollis, seu material publicitário para a AEG, austero e geométrico, é tido como pioneiro, pois foi a primeira vez que um trabalho de design foi tão amplamente adotado por uma companhia. [...] consistia numa série de regras que padronizavam os elementos gráficos de uma organização" (HOLLIS, 2001:25). A AEG contratou o sociólogo Otto Neurath, criador do sistema de pictogramas Isotype, e Peter Behrens, um pintor, arquiteto, artista gráfico e tipográfico. Este último redesenhou a marca da companhia (FIGURA 008), que assim ganhou sua famosa forma hexagonal (1907) e tipografia desenhada pelo próprio Behrens. Juntos, Neurath e Beherens projetaram um plano completo de estruturação de uma imagem unitária, desde os edifícios, escritórios, produtos, catálogos e outros materiais gráficos (FIGURA 009). Houve um sentido de reorganização e reapresentação de uma empresa multinacional. Um dos líderes da Associação Alemã de Artesãos, a Werkbund (1907).

4.... "Engloba todas las modalidades de información visual: material impresso, anúncios para la prensa, folletos, catálogos, libros, periódicos, revistas, envases, logotipos, marcas comerciales, carteles, exposicion gráficos para cine y televisión, programas audiovisuales, sistemas de signos, ilustraciones cientificas.

de aparatos y máquinas y el diseño corporativo" (MÜLLER-BRockMANN 2005 S
Behrens pregava a união entre arte e tecnologia, entre as qualidades funcionais e estéticas. Para a AEG, O designer sintetizou dois conceitos que historicamente não combinam: o neoclassicismo vindo da arte greco-romana e a Sachlichkeit (objetividade do senso

05 comum). Todo o trabalho apontava para a ideia de padronização da linguagem gráfica. Em vez de restringir-se aos aspectos mais estilísticos daqueles períodos, observou a linguagem formal e a lógica que residiam na harmonia e proporção das partes com o todo (MEGGS \& PURVIS, 2009:303), a base dos sistemas de identidade visual.

Beherens acreditava em uma ideia subjacente a essa nova imagem que apontava para uma consciência social do design e para a educação do público por meio do raciocínio industrial: "assim como seus amigos, ele acreditava que seu design era capaz de educar as pessoas a ter um gosto mais apurado, o que lhes daria uma vida melhor", (BOZTEPE, 2012:68 - tradução minha5). Compelidos pela investigação de soluções mais racionais, geométricas e livres de excessos, os movimentos de vanguarda se afastaram do pensamento eclético ornamentalista. Buscavam uma linguagem mais universal, com preocupações sociais implícitas e 20 adaptada ao mercado globalizado, que pudesse ser imediatamente compreendida por qualquer pessoa em qualquer lugar, sem regionalismos, utilizando para isso códigos elementares aplicados ao design como a malha gráfica ortogonal, a geometria euclidiana, assimetria na composição e os tipos sem serifas. Essa nova mentalidade

25 que enaltecia a racionalidade e funcionalidade do design foi posteriormente reforçada pela escola Bauhaus (1919) e, em definitivo, pelo período pós-industrialista que sucedeu à Segunda Guerra Mundial. A parti dessa fase, o design de signos visuais passa a ser utilizado em patamares mais amplos e integrados. O signo é projetado para atuar em um sistema

30 articulado, ou nos assim chamados programas de identidade corporativa que fixam critérios e normas para a aplicação de elementos em um sistema (COSTA, 2011:80). Esses sistemas estabelecem a estrutura que conecta o signo visual a todas as instâncias visuais que compõem o programa de sua identidade, "conectando partes complexas e diversificadas em um todo unificado" (MEGGS E PURVIS, 2009:534).

"Like his friends he believed that his designs were capable of educating people to have a better taste "Like his friends, he believed that his designs were ca

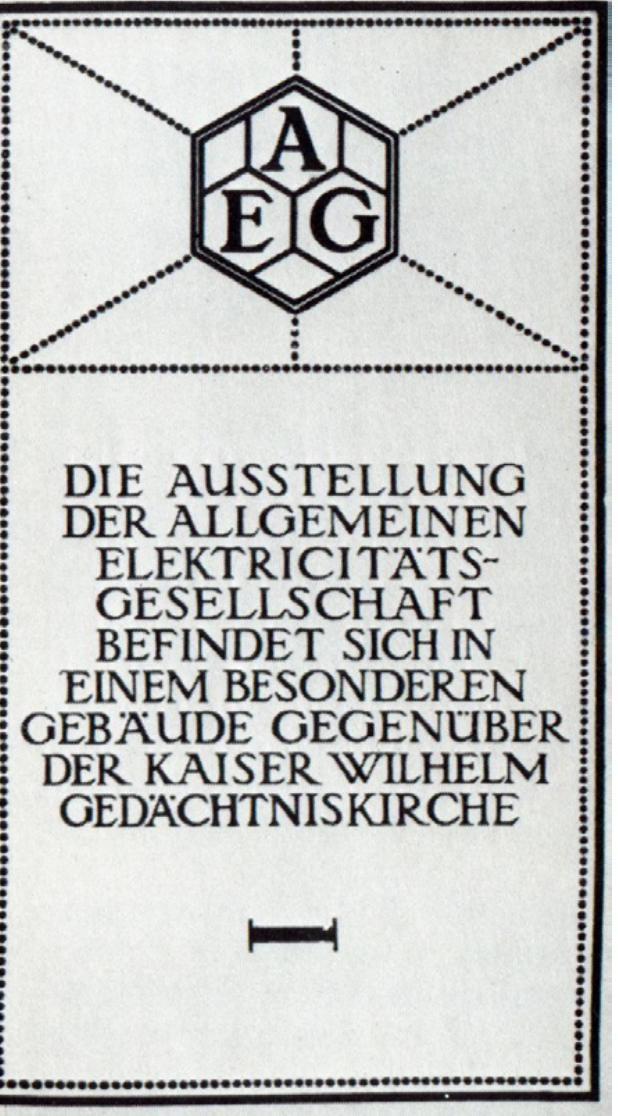

FIGURA 009_Capa do convite para "A exposição de AEG, localizada em um edificio separado, em frente à Igreja Memorial Kaiser Wilh sign de Peter Behrens, 1913. 


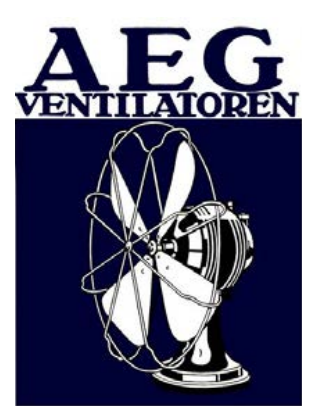

1.3.2 Behrens: uma tipografia corporativa para a AEG__ Para que todos os impressos tivessem uma unidade visual a partir dos textos, o próprio Behrens desenhou em 1907 uma tipografia para uso exclusivo da AEG, com nítida preocupação de expressar o espírito de uma nova era. Egresso do movimento Jugendstil alemão e em uma época em que as reminiscências do período vitoriano inglês e da influência do Art Nouveau e Déco ainda eram bastantes presentes, Behrens acreditava que a tipografia, depois da arquitetura, era uma área do design que "fornecia o retrato mais característico de um período e o testemunho mais forte do progresso espiritual e do desenvolvimento de um povo" (MEGGS \& PURVIS, 2009:298). Mesmo sendo um defensor de tipos sem serifas, tanto em títulos como em textos corridos, para a AEG optou por um design baseado nas proporções relativas das letras capitulares encontradas nas inscrições romanas clássicas, com uma tendência a uniformizar mais tais proporções, aproximando-as do quadrado. Como o desenho do alfabeto era manual, não permanecia constante e percebem-se versões diferentes aplicadas nos cartazes e catálogos (FIGURA 010). Os primeiros desenhos mostram uma tipografia que acompanha o design das três letras do logotipo. Inicialmente, apenas em maiúsculas e com forte contraste entre as hastes que seguem a tradição romana, - com eixo humanístico inclinado evidente (visível nos caracteres C, G, O), e um peso mais próximo de um bold. As serifas são curtas e, no remate das curvas (C, G, S) e das hastes horizontais (E, F, T), são muito inclinadas. Detalhes em algumas letras dão personalidade ao alfabeto: serifa unilateral no cume do 'A' e na base da diagonal direita; as serifas wbilaterais no topo do 'M' e 'N'; e o caractere ' $U$ ' construído seguindo as formas da letra minúscula. Esse alfabeto foi usado basicamente para títulos, como em cartazes de produtos de outros materiais gráficos da AEG (FIGURA 011).

Uma versão, que serviria de base para a produção de tipos móveis, promove alterações ousadas no design das letras (FIGURA 012). Em 1908, a Fundição Klingspor produziu sob o nome de Behrens-Antiqua os tipos móveis para uso mecanizado na impressão, desta vez, incluindo as minúsculas (FIGURA 13). Apesar da referência romana ainda presente, os caracteres não seguem a construção ortodoxa das versões manuais. Para as terminações, o tipo assume uma construção semisserifada em todas as hastes verticais, como no 'A, H, I, K, L, M, T, W' por exemplo. As serifas são quadradas do tipo slab ${ }^{6}$ sem a junção curva e sua espessura é igual à das hastes mais finas. A modulação do contraste das maiúsculas 'M, N,Z foge à regra romana e clássica. $\mathrm{O}$ eixo humanístico varia, ficando mais evidente nos ' $\mathbf{C}, \mathbf{c}, \mathbf{e}, \mathbf{G}$ ' e ausente nos ' $\mathrm{O}, \mathbf{o}, \mathbf{Q}$ '. O aspecto geral é uma mistura de formas mais arredondadas, como em b, C, c, D, d, e, G, g, O, o, P, Q, S', quadradas como em 'a, h, m, n, s, u'. As terminações de 'C, E' são tratadas de maneira completamente diferente. Os detalhes peculiares ficam por conta do bojo muito alto na letra 'a'; a terminação em ponta das hastes do 'F, P. Y'; o 'g' minúsculo com descendente fechada, como em alguns exemplares caligráficos; um remate inclinado nas diagonais do ' $\mathrm{V}, \mathrm{v}, \mathrm{W}, \mathbf{w}, \mathrm{Y}, \mathrm{Y}$ '; o 'J' com uma incomum espora na base direita da haste (FIGURA 14).

Completamente incorporada à identidade de todo o material gráfico da AEG, a tipografia Behrens-Antiqua foi usada exclusivamente pela empresa e tinha três funções principais dentro do sistema: (1) diferenciar a comunicação gráfica da AEG da de outras instituições; (2) atribuir um caráte mais universal do que individualista por meio de suas formas e proporções; (3) uma tentativa de dar um caráter monumental, com conotações positivas de qualidade e desempenho (MEGGS e PURVIS, 2009:304).

20 1.3.3 Um sistema para criar padrão e identidade_ Muitos fatores contribuem para o risco de diluição de uma marca e sua identidade. Ciclos econômicos instáveis, novas tecnologias e, acima de tudo, a enorme abundância de marcas e a concorrência pela atenção e reconhecimento decorrentes do excesso de

comunicação. As atuais expansão e diversificação de plataformas de comunicação são acompanhadas pela crescente atenção

dada aos aspectos visuais dos meios utilizados por corporções e instituições para estabelecerem pontos de contato sólidos

\section{Behrens Antiqua AaBbCcDdEeFfGgHhlijj KkLIMmNnOoPpQqRrSs TtUuVvWwXxYyzz}


com seus públicos. A proliferação de imagens ganhou poder inquestionável nas artes, na publicidade, nas relações públicas e no design gráfico. Esse cenário tem demonstrado a necessidade de uma personalização do discurso da identidade, ampliando sua eficiência e funcionalidade. Logo, é imprescindível que esse conjunto esteja bem organizado e protegido os de interferências para criar uma personalidade inconfundível. Um dos recursos para estabelecer alguma ordem e manutenção das linhas básicas de uma identidade é o registro físico das normas que regem o uso da marca e suas relações com os mais diversos ambientes e cenários em que pode atuar. Como define Norberto Chaves:

o "manual do sistema de identificação visual" é o resultado das exigências de normalização da imagem gráfica. Estes manuais de uso estendido na gestão da imagem institucional — cumprem várias funçōes além de um guia para a reprodução fiel dos signos: capacitação das equipes internas para a gestão de imagem, capitalização operacional do design gráfico corporativo, etc. (CHAVES, 2005:69 - tradução minha')

O chamado Sistema de Identidade Visual (SIV) é um instrumento de 20 gestão de uma marca que estabelece as normas de aplicação de seus elementos identificadores, determinando exatamente como são e como devem ser apresentados, organizando as conexões e o encadeamento desses elemento nos diversos suportes gráficos (impressos, editoriais, digitais) e paragráficos (arquitetura, indumentária, etc.) (CHAVES, 2005:67). Alina Wheeler (2008:176) observa que o controle da consistência e a integridade da marca em um sIV são facilitados por padronizações e diretrizes inteligentes acessíveis a todos os participantes da comunicação da marca. Para a designer brasileira Ana Luísa Peón (2003), o siv é a configuração objetiva de uma identidade e o define como um "sistema de normatização para proporcionar unidade e identidade a todos os itens de apresentação de um dado objeto, através de seu aspecto visual. Este objeto pode ser uma empresa, um produto ou serviço" (PEÓN, 2003:15). É uma prioridade na consolidação do discurso corpo-

7 El umanual del sistema de identificaciónn es el resultado de las exigências de normalización de la imagen gráfica. Esos manuales -de uso extendido em la gestión de la imagen institucional-cumplem varias funciones además de la guía para la reproducción fiel de los signos: capacitación de los equipos internos em gestión de magen, capitalización en imagen del operativo de diseño de la gráfica institucional, etc. (CHAVEES 2005:69). or rativo ou institucional especialmente para aqueles que atuam extensiva mente no ambiente público, assegurando a consistência, memorização permanência de sua identidade original. Impressos ou em formato digital, os manuais de siv abrangem desde as estruturas e proporções elementares

o5 da marca, suas possíveis configurações cromáticas, tipografias, grafismos, até as especificações de como todos os elementos devem ser apresentados nos diversos suportes impressos e digitais. Segundo Joan Costa (2011) esse conjunto de diretrizes é sistematizado, no sentido de uma organização estruturada composta de um número variável de elementos diversos, intera-

10 ções entre eles e as leis, criando ao mesmo tempo um mecanismo dinâmico, coeso e regrado: "A ideia de 'sistema' implica a ideia de rede e de organização de suas partes, onde todas elas são interdependentes" (COSTA, 2011:95). Esse autor formula uma boa definição sobre a função contextualizadora de um sistema de identidade:

A disciplina da identidade corporativa compreende a aplicação dos signos em seus diferentes suportes e dita uma norma que assegura a correta e uniforme apresentação da marca e, desta forma, da empresa. Esta é, em resumo, a diferença essencial com relação ao design de marcas - não de programas - que excluía o problema implícito de seu desenvolvimento e critérios de suas aplicaçōes em favor da marca-signo exclusivamente, sem levar em conta os suportes e os contextos em que teria de funcionar (COSTA, 2011:80).

25 Se na atualidade, os manuais de identidade são obrigatoriamente formatados para os ambientes virtuais por questões de economia de custos e facilidade de uso e de atualizações, no início de sua prática eram regularmente impressos, cada item de seu conteúdo era alocado em uma página separada e agrupado em uma encadernação não perma-

3o nente (do tipo fichário), possibilitando também complementações correções e remanejamento das informações ao longo do tempo. Toda manifestação da marca realizada por funcionários, designers ou fornecedores de materiais gráficos, deveria obedecer às especificações contidas no manual, evitando qualquer desvio ou aplicação incorreta de seus 35 princípios. Dessa maneira, desde os impressos administrativos até a apresentação de informações na web, o mesmo caráter visual é mantido de acordo com as regras que foram projetadas. Na sua forma virtual, 
A palavra MARCA pode se referir a um conceito bastante amploe intangivel, se referindo a uma empresa como um todo sua (n) produtose seviços (oulns 2008 . No sentido visual, mais tangível, MARCA éa representação gráfica de um signo linguistico (nome, denominação) e escritural (traço alfabético, tipografia) - LogoTIPo e um signo icônico (símbolo, ícone, imagem) - símboLo - associados a um signo cromático (COSTA, 2011: 22).

disponivel on-line ou em arquivos digitais, não são raros os manuais que disponibilizam alguns modelos padronizados de algumas aplicações para utilização direta pelos usuários.

1.3.4 A composição predominante de um SIV__ A estrutura de um sIV é essencialmente dividida em dois blocos: os elementos identificadores primários e as aplicações gráficas. A composição e ordenamento desses elementos variam de acordo com o perfil de cada caso. Além dos elementos primários, detalhados em suas construções, especificações técnicas e orientações executivas, as aplicações ocupam parte importante desse conjunto (passim WEELER, 2008 e CONSOLO, 2012). Aqui, a sintaxe visual é de fato estabelecida. Não se trata apenas de estampar a marca, em uma determinada cor e tamanho, em diversos materiais gráficos e digitais, mas projetar a correta articulação dos elementos para que exprimam corretamente a identidade em cada peça ou material gráfico.

Os elementos primários que constituem uma identidade visual - nome, marca, cor e tipografia - são articulados para formar valor, significados e uma imagem mental que delimita as qualidades de seus referentes, ao mesmo tempo em que estabelecem a tangibilidade visual da marca (passim CAUDURO, 1972; OLINS, 1995; AAKER, 1998; ALLEN e SIMMONS, 2004; CHAVES, 2005; KAPFERER, 2003, WHEELER, 2008; COSTA, 2011). São dispositivos que auxiliam a identificação e diferenciação de uma marca. A importância ou prerrogativa que cada um desses três elementos assume no sistema, varia conforme o propósito da instituição como, por exemplo, a atenção dada à tipografia no setor editorial de notícias. Nesse sentido, pode-se afirmar que a comunicação visual e a escrita formam uma unidade inseparável por meio da tipografia, como um meio complexo e plenamente desenvolvido de expressão (LEEUWEN, 2005:138). Este raciocínio não se aplica apenas a empresas comerciais, mas também é indispensável para qualquer organização que dependa de uma correta exposição pública. Jorge Frascara (2006) observa que, entre os elementos básicos de uma identidade visual, o aspecto da mensagem escrita é uma das ferramentas mais importantes: proporciona impacto na percepção de marcas e publicações, influencia a memorização e reconheciment de anúncios publicitários, tornando-se um agente estratégico para a comunicação:
Aidentidade é um dos bem mais importantes de uma empresa comercial ou de uma organização sem fins lucrativos. A identidade não é exclusiva do mundo dos produtos ou dos serviços de consumo. As publicaçōes também a exploram para assegurar a fidelidade de seus leitores. As capas de revistas, o material editorial $e$ o design de jornais representam um terreno em que a identidade emerge de decisōes do detalhe particularmente conectadas à

tipografia e à diagramação. (FRASCARA, 2006:133 - tradução minha)

Da mesma forma que as imagens, a tipografia oferece significados ou contextos culturais alternativos para a identidade de uma marca proporcionando uma memorização mais duradoura (BUDELMANN et al, 2010:48 - tradução minha9 ). Essa função pode se realizar com tipografia deusocorrente,aquelasencontradasemcatálogoscomerciaisedisponívei a qualquer um, e com tipografias customizadas, projetadas unicamente para uma determinada organização e utilizada exclusivamente por ela como veremos mais adiante.

Os componentes de um manual de identidade visual são, de modo geral, os seguintes:

\section{Elementos Identificadores Primários:}

Os sIv são compostos por três pilares que configuram uma identidade visual e apartir dos quais toda a linguagem visual está estruturada. O elemento mais importante é a marca, um de signo que pode reunir

um sinal gráfico (símbolo) e/ou um sinal verbal (logotipo ou tipograma). Este elemento deve ser sempre apresentado em cores definidas e estar acompanhado de uma tipografia padronizada.

\section{Marca}

30 Apresentada em suas estruturas básicas: símbolo, logotipo; taglines ou slogans; variações de posição e alinhamento;

"La identidade es uma de las posesiones más importantes de uma empresa comercial o uma organización sin (1) editorial yel diseño de diários representan un terreno em el que la identidade emerge de decisiones de detalle (BUDELMANN et al), 2010:44:-
Esta dissertação adota o termo Instituição para se referir às associaçōes corporaçoes, organismos ou empresas de cunho comercial, cultural profissional ou outra.

Instituição: inicialmente, uma entidad que exclui a funç̃o lucrativa, não-empresarial (COSTA, 2011:20).

Instituição: 6. organismo público ou privado, estabelecido por meio de

leis ou estatutos, que visa atender a uma necessidade de dada sociedade ou da comunidade mundial (Hovals 2001:1627).

Corporação: Termo que adquire conotaçōes distintas conforme o idioma: no contexto conforme refere-se à empresa, companhica, diferente do contexto la tino que pode expandir para associacões públices e outros setores da sociedade Na idade média as sociededes mercan is de mentra, as oficios as corporacões de oficio os oficios, as corporaçoes de oficio, "nde encontra-se a origem da pa (COSTA, 2011:49).

Corporação: 1. conjunto de pessoas com alguma afinidade de profissão, ideias etc., organizadas em associação e sujeitas a estatuto ou regulamento; 3. empresa ou grupo de empresas de grande porte e de forte presença em um ou mais setores (HOUAISS, 2001:843-2). 
Ainda neste segmento, são estabelecidas todas as instâncias gráficas $\quad 01$ para sua construção e preservação de legibilidade como:

Grade de ampliação

b. Grade de construção geométrica;

c. Área de proteção, espaço periférico à marca no qual não é permitida a interferência de nenhum outro elemento gráfico;

d. Indicação de redução mínima:

e. Possíveis enquadramentos (recortes) da marca

f. Usos incorretos/não permitidos;

g. Associações e composições com outras marcas;

\section{Cores}

Definição do padrão cromático da marca, demonstrado em vários siste-

mas de cores disponíveis e necessários a cada caso.

a. Padrões CMYK, RGB, WEB, Pantone ${ }^{\circledast}$, tintas industriais

e outros

Configuração em preto e branco, meio tom (cinzas)

filetado e relevo seco;

c. Padrão cromático secundário (cores de apoio que

podem ser usadas associadas à marca);

d. Comportamento da marca sobre fundos coloridos, em preto \&

branco e sobre fundos conturbados

e. Situações cromáticas não permitidas (prejuízo de

legibilidade e contraste).

\section{Tipografia}

Não apenas é indicada a tipografia utilizada no logotipo (quando aplicável), mas principalmente a(s) tipografia(s) utilizadas em toda a comunicação textual. É recomendável a indicação do designer do tipo, ano de criação e distribuidora, facilitando sua localização e aquisição. Os principais itens são:

a. Tipografia para títulos curtos;

b. Tipografia(s) utilizada(s) em textos longos;

c. Tipografia(s) alternativa(s) para web;

d. Articulação entre os tipos para título e texto.

c. Regras de diagramação, hierarquia tipográica, alinhamentos e entrelinhamentos.
A esse bloco de itens, somam-se eventualmente, elementos secundários que dão suporte à marca como grafismos ou padrões gráficos, materiais de superfície (acabamento), pictogramas, vinhetas sonoras, marcadores aromáticos e mascotes.

\section{Aplicações Gráficas:}

Qualquer peça gráfica, digital ou material na qual a marca ou um de seus elementos identificadores estejam aplicados. Devem obedecer a regras definidas e constantes, marcadas por medidas métricas ou proporcionais 10 permitindo ao usuário compreender a lógica dessas aplicações e reproduzila em qualquer situação idêntica ou similar.

Papelaria Básica

Cartão de visitas, papel carta, envelopes:

\section{Papelaria Comercial Interna}

Documentos internos com informações variáveis, como memorandos, formulários, notas fiscais, ordens operacionais, etc:

20 Material de Comunicação

Comunicado padronizados para imprensa, pastas press-kit, pasta-portfólio

\section{Comunicação Extern}

Estrutura de anúncios publicitários, cartazes, folhetos, banners, vinhetas

para vídeo e outros materiais publicitários; homepage, assinatura de e-mail e novas mídias;

\section{Sinalização}

Interna e externa, fachadas e arquitetura, ponto-de-venda;

\section{Embalagens}

Planificação detalhada de linha de embalagens, com especificações métricas, materiais e técnicas de impressão;

\section{$35 \quad$ Uniformes}

Detalhamento de aplicação da marca, modelo e tecidos dos uniformes de todos os escalões de funcionários: 


\section{Veículos de Erota}

Veículos leves: bicicletas, motocicletas, automóveis e furgões;

veículos pesados: caminhonetes e caminhões;

\section{Ambiente Corporativo}

Ambientação arquitetônica interna e externa; aspectos sensitivos

(táteis e visuais) de materiais; mobiliário integrado a diretrizes de comunicação e sinalização;

\section{Materiais Efêmeros}

Material de merchandising comumente relacionados a brindes como sacolas, mouse pads, agendas, calendários, medalhas, relógios, etc.

\section{Amostras e gabaritos (templates)}

Muito comuns nos manuais impressos, anteriores ao design digital, esta seção dos siv contém amostras de cores de sistemas padronizados para reprodução (Pantone ${ }^{\oplus}$ e/ou outras) e amostras impressas da marca em diversos tamanhos. Tais amostras servem para auxiliar e orientar fornecedores na fabricação de materiais gráficos, peças de sinalização e outros materiais efêmeros.

1.3.5 Brand Books_Em alguns casos, esta forma de definição e proteção da integridade de uma marca - Manual de Identidade — tem se mostrado insuficiente ou inadequada para acompanhar as crescentes demandas da comunicação atual, a qual necessita atender as constantes flutuações de comportamento do público e a veloz transformação dos canais de comunicação proporcionados por novas mídias digitais. Se as orientações e regras contidas naqueles manuais forem seguidas à risca, podem, em contrapartida, criar situações demasiadamente restritivas ou inibidoras de qualquer inovação no conteúdo e na forma como as mensagens são difundidas. Além dos já citados (marca, cores e tipografia), outros elementos identificadores primários que ampliam a percepção da identidade são agregados como, por exemplo, a linguagem fotográfica adotada e o chamado 'tom de voz' das mensagens e os estilos da expressão verbal, ocasionalmente designado de look and fell, ou como se vê e como se sente (oLLINS, 2009:30). Como alternativa a esse modelo, os programas de comunicação e marketing têm adotado outro formato que integra as diretrizes mais primárias do uso o1 visual da marca, as estratégias e linguagens para a comunicação, na qual o estilo visual e verbal é articulado com os pontos de contato da marca e outras formas relativas de expressão: o chamado manual da marca ou brand book (BB). Também conhecido como Style Guide, о вв é um conjun-

05 to de orientações que expõe a marca em uma dimensão mais ampla flexível: aborda seus valores, atributos imateriais, posicionamento, tom de voz, linguagem visual e formas de interação. Trata-se de publicações mais focadas em transmitir o conceito e o posicionamento da marca. "É uma tentativa de corrigir o problema de 'engessamento' da comunicação [...]. A

in iniciativa dos brand books é apresentar as possibilidades gráficas, e não os documentos finais dentro de um sistema predefinido. A apresentação da linguagem visual e verbal da marca passou a ser de cunho inspiracional'." (CONSOLO, 2012:153). Do mesmo modo que um вв prescreve precisamente como uma identidade é gerida, também é um recurso que possibilita

15 mudanças de comportamento em relação à marca, apoiando visualmente e exteriorizando essas mudanças. Nos BB, aspectos mais intangíveis e emocionais são incorporados para abranger toda a personalidade da marca: 0 tom do discurso verbal e textual e pontos mais sensíveis e sujeitos a interpretações, representados pelo estilo do universo imagético associado a ela.

m um BB, os elementos listados no sIV são resumidos aos mais essenciais ou selecionados de acordo com a empresa, incorporando os seguintes:

\section{A Marca (brand)}

Visão, valores, missão, crenças;

25. Posicionamento:

Personalidade, expressão da marca;

Conceitos ligados à marca;

Mensagem;

Identidade sonora.

\section{Estilo imagético}

Elementos gráficos de apoio;

Estilo de fotografias;

Estilo de vídeo;

$35 \quad$ Estilo de ilustrações;

Texturas, grafismos, padronagens;

Banco de imagens; 
Tipo de locações:

Tipo de elementos (pessoas, objetos, etc.)

Associação de imagens com texto/mensagens:

Meios de arquivamento;

Reserva de direitos:

Materiais: dimensão tátil e simbólica.

\section{Estilo verbal (tom de voz)}

Estilo gramatical;

Estilo geral de linguagem;

Estilo formal;

Estilo coloquial;

Estilo promocional.

Deve-se ressaltar que não existe um padrão definido e adotado por 15 todos. É comum haver alguns itens de um вв em um siv e vice-versa.

1.3.6 A tipografia nas marcas Nos sIV e nos BB, a tipografia empregada em logotipos, quase nunca é especificada nominalmente quanto à origem e autoria, pois, em geral, as letras recebem alguma manipulação 20 que adapta seu desenho às peculiaridades do nome. Portanto, o detalhamento desse item se concentra na construção, proporções, cores e posicionamento dos elementos da marca. Os siv mais completos se ocupam também de determinar exatamente o espaçamento entre as letras do logotipo, não deixando margem para nenhuma variação.

No design da marca, o logotipo é um sinal verbal composto por uma camada denominativa (o nome) e uma camada visual (design). A escolha tipográfica reforça esta a segunda, enriquecendo semanticamente as funções identificadoras do logotipo (COSTA, 2011:47). Em todas as outras formas de comunicação escrita, o uso de um tipo adequado e alinhado com a identidade aprofunda a inter-relação de todos os seus elementos e ganha força nos ambientes em que a marca não alcança ou não está presente, como avisos, vinhetas de vídeo ou sinalização de ambientes. Nesses casos, a tipografia e o modo como é articulada no design também assumem a prerrogativa de identificar. Para que isso ocorra, ela deve ter um caráter adequado único e intransferível. A tese é confirmada em testes conduzidos por vários pesquisadores, como o realizado por John R. Doyle e Paul A.

o1 Bottomley (2004), por exemplo, em que relacionam marcas fictícias de produtos, de diferentes categorias, com uma gama variada de tipografias. As marcas elaboradas com tipos mais apropriados a cada segmento tiveram o dobro de aceitação do que aquelas apresentadas com tipos meno

o5 adequados. Isso pode ser explicado pelo que os autores chamam de visual equity, ou o valor derivado da forma visual da palavra que contribui para o seu reconhecimento e memorização (DOYLE, BOTTOMLEY, 2004:873).

Observando que todos esses elementos convergem na construção de uma identidade e, consequentemente, de uma imagem da instituição.

- cabe definir ediferenciar os conceitos de identidade corporativa eimagem corporativa. João de Souza Leite (2011) cita o designer de marcas britânico Wally Ollins que destaca o elo que conecta a identidade pretendida de uma corporação e a imagem percebida pelo público: a manifestação tangível de uma personalidade corporativa é a identidade corporativa. É a identidade que

5 projeta e reflete a realidade da personalidade corporativa. Algumas vezes, como sabemos, a identidade corporativa é introduzida como um catalizado para encorajar o desenvolvimento de uma personalidade corporativa outras vezes ela reflete não aquilo que ela é de fato, mas o que a corporação gostaria de ser. A imagem corporativa é aquilo que as pessoas realmente 20 percebem da personalidade corporativa (souzA LEITE, 2011:20-29).

Paul Capriotti (2005) entende que a imagem corporativa é um ponto de vista construído no imaginário das pessoas, é o que parece ser, um conjunto de significados que as pessoas associam a uma organização. São impressões, resultado de abstrações e experiências individuais, portan-

25 to são inconstantes, flutuam de acordo com o desempenho e comportamento do negócio e sua relação com o público. A identidade corporativa, por sua vez, deve garantir e expressar o que a empresa é, a expressão mais tangível de sua personalidade, presente tanto na comunicação como no comportamento de uma organização. Como estabelece o autor:

Podemos definir a Identidade Corporativa como um conjunto de características centrais, perduráveis e distintivas de uma organização com as quais a própria organização se autoidentifica (no nive introspectivo) e se autodiferencia (das outras organizações ao seu redor). Por características "centrais" nos referimos àquelas que são fundamentais e essenciais para a organização, que estão em seu DNA corporativo. (CAPRIOTTI, 2005:21 - tradução minha ${ }^{10}$.
10 Podemos definir a la Identidad Corporativa comoel conjunto de características centrales, perdurablesy distintivas de una organización con las que la propia organización se
autoidentifica (a nivel introspectivoly diferencia (de las ortas organizaciones desuentorno). Al hablar de caracteristicas" "entrales" nos referimos a aquellas que son fundamentales nos refer mosos a aquellas que son fundamentales
y esenciales para la organizzción, que están en su ADN Corporativo (CAPRIOTT, 2009:21). 
Pode-se concluir que a imagem corporativa (um conceito gerado de for para dentro) é consequência de vários fatores, entre os principais, a expressão visual mais tangível ou identidade visual (gerada de dentro para fora).

Para aclarar o caráter polissêmico do termo e ampliar o sentido comumente assumido de predominância do caráter visual, Norberto Minguez (1999) oferece duas perspectivas para compreender o termo: uma identidade corporativa interna, representada pela noção autoconsciente da organização, ou seja, a imagem que ela própria tem de si, e identidade corporativa global, mais ampla, que é constituída pelos traços mais essenciais que diferenciam a instituição das demais. Esta última perspectiva refere-se à realidade da empresa, como ela se percebe e qual o seu comportamento. É determinada por quatro fatores:

a Comportamento: a atuação da organização do ponto de vista funcional, seus produtos e serviços, procedimentos administrativos, produtivos, financeiros, tecnológicos ou comerciais;

b. Cultura Corporativa: conjunto de valores e princípios compartilhados pela maioria dos membros da instituição. Estes valores são, simul- 2 taneamente, elementos de integração interna e de construção social da identidade corporativa.

c. Identidade Visual: conjunto de signos que traduzem graficamente a essência corporativa. Estes elementos são regulados por um código combinatório que determina a forma e os usos do logotipo, símbolo, das cores corporativas e do identificador (Manual de Identidade Corporativa).

d. Comunicação Corporativa: conjunto de formas de expressão que apresenta a organização. Na prática, todos os atos cotidianos do comportamento de uma empresa são, em última análise, atos comunicativos.

O que o autor pretende demonstrar é que essa perspectiva global da identidade corporativa não tem um caráter simplesmente visual, mas alcança aspectos culturais, ambientais e de comportamento, alude a um conjunto de modos de ser e de fazer compartilhados por um grupo de indivíduos e que podem ter um valor estratégico (MINGUEZ, 1999, s.n.).
Considerando a identidade visual a representação gráfica de uma dentidade e parte de um conjunto mais complexo, a tipografia institucional é um elemento que permeia tanto os canais de comunicação internos

o5 como os externos e está em contato direto com o público mesmo em situações em que a marca ou a cor institucional não estão presentes na comunicação. Adquire, então, mesmo que de modo sutil, uma responsabilidade identitária tão importante quanto a própria marca. Evidentemente, tal valor varia de intensidade de acordo com a área de atuação e meios utilizados na

10 comunicação. Ainda assim, as especificações tipográficas compõem um capítulo exclusivo nos Sistemas de Identidade Visual, descrevendo o tipo usado no logotipo, suas proporções e espaçamento, e também as fontes usadas em todo o conteúdo escrito, desde anúncios publicitários, meios digitais, até os documentos administrativos internos e externos. Nas

15 descrições mais completas, as fontes são relacionadas em todas as suas variações estilísticas (peso, amplitude, postura, etc.) assim como são mencionados o designer, ano de lançamento e distribuidora (type foundry) onde as fontes podem ser encontradas comercialmente.

\subsection{A TIPOGRAFIA EM SISTEMAS DE IDENTIDADE VISUAL}

Entre os elementos primários que compõe um BB ou um sIv a tipografia é um instrumento fundamental na criação e integração de toda comunicação verbal que utiliza a palavra escrita. Isso se mostra ainda mais necessário quando observamos a grande variedade de mídias, em

25 especial as mídias digitais com diferentes suportes, resoluções e fabricantes, em que a tipografia pode ser alterada por exigências técnica de cada dispositivo. As instituições que utilizam canais de comunicação variados como jornais, revistas, ambientes, vídeos, sites e aplicativos, compreendem que a tipografia é um meio com sua própria mensagem. Torna-se

3o crucial que a mensagem ou a impressão que a tipografia adotada transmite, seja consistente em qualquer meio empregado para sua difusão (passim STÖCKL, 2005; HENDERSON, GIESE e COTE, 2004). Atenta a esta questão, a designer tipográfica espanhola Laura Meseguer (2011) destaca a relação entre os tipos e o conteúdo: "O tipo de letra deve criar o tom certo

35 para a transmissão de informações escritas, assim como a 'estética' ajuda a definir e personalizar o ambiente no qual a informação é apresentada" 
(MESEGUER, 2011:169 - tradução minha"). A perspectiva de uma atuação ativa da tipografia sobre a informação é compartilhada por Norberto Chaves ao afirmar que

Cada mensagem preanuncia-se pelo seu gênero, com o correspondente código gráfico. Uma mensagem sem gênero, sem conter uma determinada linguagem, é uma mensagem lenta, levando mais tempo a ser descodificada. 0 gênero - o tipo adianta ao receptor a informação que the permite, antes de ter o conteúdo da mensagem, selecionar o paradigma interpretativo apropriado (CHAVES, 2012, s.n.).

Caractere Cada uma das letras, númerose compõem uma fonte tipográfica. ou que fazem parte

de um sistema de escrita (FARIAS, 2004a, s.n.). Tipografia Conjunto de práticas subjacentes à criação e utilização de símbolos visíveis relacionado aos caracteres ortográficos (letras) e para-ortográficos (numeros e sinais de pontuação), para fins de reprodução (FARIAS, 1998: 11). Família Tipográfica O termo refere-se ao conjunto formado por uma fonte (em estilo normal ou regular) e suas variaçōes (bold ou erito lisht strico ves (bold ou Typeface Literalmente, 'face de tipo', ou o desenho de um conjunto alfanumérico

coerente, independente de sua implementação enquanto fonte' (FARIAS, 2004a, s.r.).

Uma coleção de todos os caracteres tipográficos que partih an dos mesnas tipograf cos que pade resign como peso largura inclinac̃o argura, inclinaçāo, tamanho optico, das serifas (TYPOPHILE, s.d.).
Essa visão aponta a influência do design tipográfico como condutor de uma "mensagem invisível", que estabelece conexões básicas, diretas e permanentes com o leitor.

Não há unanimidade que garanta uma correta e infalível seleção de tipos para um projeto de identidade visual. O que se pode constatar é 0 destaque dado à tipografia e ao seu desempenho uniforme e disseminado em todas as manifestações gráficas do projeto. Mesmo que isso passe despercebido do público comum, o tipo de letra usado para representar 20 uma ideia ou negócio é tratado com atenção especial pelos designers, atentos aos valores subjetivos do signo alfabético. Uma tipografia corporativa, juntamente com a marca e padrão cromático é um componente crucial para consolidar a identidade, pois comunica em um nível mais sutil, mas de extrema relevância carregando extensivamente a mensagem central tanto no ambiente interno como no externo, inclusive quando os outros elementos estão ausentes. Consequentemente, constrói por meio da forma visual dos conteúdos textuais um alinhamento permanente com todos os códigos da identidade.

A atenção e importância dada à tipografia nos siv variam de acor- 30 do com a estratégia definida para a comunicação e para a identidade. Asim, a tipografia pode estar relacionada com um dos pilares do sistema ou simplesmente figurar como um elemento secundário de apoio à marca. Em manuais como o do metrô de Londres, a emblemática tipografia New Johnston é o primeiro elemento a ser apresentado, antes

The typeface should create the right tone for conveying written infromation as the "caesthetics" hellp define and cus should create the right tone for conveying written infromation as the "aesthetics, mesmo da famosa marca evidenciando-a como protagonista de todo o sistema e ponto central da identidade. Em outros, surge no meio ou fina do manual. Nas situações em que a marca é muito forte e intensamente difundida ou quando imagens cumprem um papel predominante,

05 carga expressiva da tipografia tende a ser minimizada, resultando no uso de tipos apropriados para funções mais secundárias. Nesses casos, as opções recaem sobre os tipos cujas características e funcionalidade já foram estabelecidas e sua receptividade já foi testada (Helvetica Univers, Futura, Gill Sans, Officina, e outras). Outra condição é aquela

10 em que a presença da marca não é tão predominante quanto a da tipografia. Essa é uma situação comum no campo editorial, por exemplo, no qual o leitor tem um contato muito mais próximo e longo com o texto. Em uma situação assim, a escolha de um tipo que particularize a publicação é uma decisão recomendável e cada vez mais adotada. Tipografia

15 projetadas exclusivamente para esse tipo de projeto exigem o envolvimento de designers especialistas (type designers, ou designers de tipos) e empresas especializadas (type foundries, ou distribuidora de tipos). Menos frequentes, há ocasiões em que um produto específico ou uma ação não permanente requerem uma seleção tipográfica à parte, não 20 desgastando aquela usada no sistema de identidade e assegurando certa peculiaridade do projeto (Nike Football).

Nos manuais de SIV, o capítulo destinado à tipografia institucional pode variar na classificação das prioridades tipográficas. É comum haver três grupos distintos: tipografia primária, secundária e para a web. A

25 tipografia primária consiste naquela ou naquelas opções que se encaixam no projeto gráfico e que devem ser utilizadas obrigatoriamente nos materiais impressos ou digitais e são totalmente gerenciadas pelos usuários da marca. Normalmente, é apresentada como uma família tipográfica, ou seja, composta no mínimo dos quatro estilos básicos: regular, itáli-

co, bold e bold itálico. A tipografia secundária indica opções alternativa para situações em que a tipografia primária não está disponível na distribuição de material digital para terceiros, como em apresentações digitais, formulários ou arquivos de documentos em seu formato nativo (MS Word, por exemplo). Por fim, a tipografia para a web define opções de fontes

5 pré-instaladas nos principais sistemas operacionais (web safe fonts ou core fonts), frequentemente selecionadas pela similaridade com as tipografias primárias. Alguns sistemas mais detalhados oferecem também as linhas 




FIGURA 015_Detalhes do Brand Book digital da Ford Feel the Difference presentando as fontes Ford Light $e$ Ford Bold e seus nomes compostos.

\section{ABCabc128 \\ ABCabc123}

FordFocus

FordKa

FordTransitConnect

FordPrivilege
Fordinsure

Fordinsure

FordFleet
FordCredit

IGURA 016 _Amostra do uso da

tipografic Amastra do da tipografia en anuncios, com os texto em quadros brancos.

gerais das regras tipográficas e de diagramação a serem seguidas como o uso alternado de tipos serifados e sem serifa, os tamanhos das letras para o corpo dos textos, tamanhos para títulos, subtítulos, capitulares e textos pequenos (notas, rodapés, marginália, etc.), indicações para espaçamento entre pares de letras específicos (kerning), espaçamento entre letras (tracking) e espaçamento entre linhas (leading). De todas as configurações, a tipografia primária é a que recebe maior atenção, sendo apresentada, na maioria das vezes, com as famílias de tipos e suas variações de estilos (variações de peso e de largura, itálicos, letras serifadas e sem serifa).

Para ilustrar como a tipografia é retratada em manuais de identidade visual, foram analisados seis manuais de identidade, entre 121 amostras de exemplares físicos, arquivos digitais e online, que despendem atenção especial para este item e mostram um panorama diverso no tratamento dado ao assunto, tanto nas propriedades qualitativas das fontes corporativas quanto na profundidade do detalhamento do uso correto das opções tipográficas em seus contextos.

1.4.1 Ford Brand Book da Montadora Ford - Feel the Difference elaborado em 2006, apresenta a fonte Ford Light e Ford Bold, desenvolvida pela type foundry FontShop Corporate Font. As fontes são adapta- 20 ções das originais Helvetica Neue 43 Light Extended e Helvetica Neue 73 Bold Extended. Elas são a base para todos os materiais de comunicação, incluindo uma assinatura que acompanha todas as peças. As duas versões Ford Light e Ford Bold (FIGURA 015) contrastam nos seus pesos e são empregadas sempre de forma alternada, criando ritmo acentuado no texto, com o estilo bold sempre reforçando o nome Ford (FIGURA 016). A proporção expandida das letras remete ao universo visual automobilístico que, por sua vez, remete a velocidade e alto desempenho. O uso predominante do estilo mais leve (light) também está supostamente associado ao design preciso e leve dos automóveis.

1.4.2 Futurice $\mathrm{O}$ brand book da empresa finlandesa de softwares para dispositivos móveis, Futurice, é dividido em dois capítulos: o primeiro discorre sobre a visão da marca, sua história, o que promete e sua missão; o segundo fornece o guide line ou as diretrizes a serem seguidas, mostrando a marca e seus elementos. O documento determina o uso da família tipográfica Museo Sans. Essa tipografia, desenhada por Jos Buivenga em 2008 e distribuída

\section{HUGE HEADING}

Regular heading

Smaller heading

Subheading

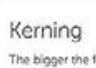

\section{Big \\ Bigger \\ Biggest \\ Bigger}

pela ExLibris Type Foundry, e disponível comercialmente oferecendo três variações pesos gratuitamente. O manual estabelece o uso de cinco pesos (100, 300,500, 700 e 900) com suas itálicas indicando pesos diferentes para situações hierárquicas determinadas. Especifica também, de forma gené20 rica, ajustes de espaçamento para tamanhos grandes (FIGURA 017).

O fato de essa família de tipos ser acessível a qualquer pessoa reduz a capacidade de atribuir exclusividade unicamente pela tipografia assim, estabelecer uma identidade mais destacada. Nesse caso, outros recursos de design são empregados, tais como o uso da cor institucional, 0

25 contraste nos tamanhos e o alinhamento dos textos sempre pela esquerda. Contudo, a Museo Sans é orientada apenas para materiais impressos ou digitais produzidos pela própria Futurice. $\mathrm{O}$ uso de fontes alternativas é previsto para apresentações (Corbel e Gill Sans), documentos de texto (Corbel, Lucida Sans e Geneva Regular) e web (Sans, Arial Lucida Sans - Century Gothic, além da própria Museo Sans).

1.4.3 Carrefour Para o manual da rede de supermercados Carrefour, o capítulo reservado à tipografia no BB, desenvolvido em 2009, apresenta três situações: Tipografia primária para títulos em publicações profissionais

5 Tipografia secundária, para textos mais longos; e Tipografia para desktop e online. Juntamente com as indicações de uso, o manual menciona aspectos de personalidade de cada fonte e em que situações devem ser usadas. 


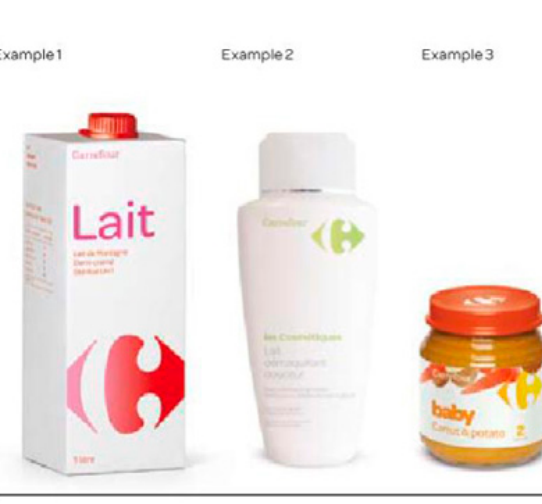

FIGURA 018_ Detalhe da página do brand book Carrefour apresentando a fonte Omnes como a tipografia primária. Complementam o manual,
as fontes Gotham Narrow e Arial.

\section{Abc}

AaBbCcDdEeFfGgHhliJjkkLIMmNnOo

PpQqRrSsTtUuVvWwXXYYYZz1234567890

AaBbCcDdEeFfGgHhliJjKkLIMmNnOo

PpQqRrSsTtUUVYWWXXYYZZ1234567890

AaBbCcDdEeFfGgHhliJjKkLIMmNnOo PpQqRrSsTtUuVvWWWXxYyZz1234567890

\section{AaBbCcDdEeFfGgHhliJjKkLIMmNnOo} PpQqRrSsTtUuVvWwXXYyZz1234567890

\section{AaBbCcDdEeFfGgHhliJjkkLIMmNnOo}

PpQqRrSsTtUuVvWwXXYyZz1234567890

Nas publicações primárias, ou seja, nos títulos de anúncios e material publicitário, utiliza-se a família Omnes nos pesos light, medium, reguar, semi bold e bold (FIGURA 018). Essa família não tem serifas e apresenta uma base estrutural geométrica, suavizada por cantos arredondados e remates curvos. $O$ texto descritivo do manual ressalta a diferenciação do tipo usado no logotipo, com seu tom humano, de personalidade amigável, que estreita e fortalece a relação mental com os consumidores. Os pesos são distribuídos para usos específicos: medium para títulos e nome de produtos em embalagens; regular para informações de apoio e no corpo do texto; semi bold como estilo que contrasta com as regular e medium, e light e bold para casos especiais que demandem diferenciação em produtos.

A tipografia secundária, Gotham Narrow, complementa a Omnes e indicada exclusivamente para longos textos com informações detalhadas e nos quais o espaço é limitado (versos de embalagens, por exemplo). A fonte, sem serifas, é levemente condensada e foi projetada para textos. Faz referência à tipografia vernacular norte-americana, presente na paisagem urbana do inicio do século xx, que se tornou icônica daquele país.



\section{vesal ientity + Our typeface}

Birtish councis
exceptions

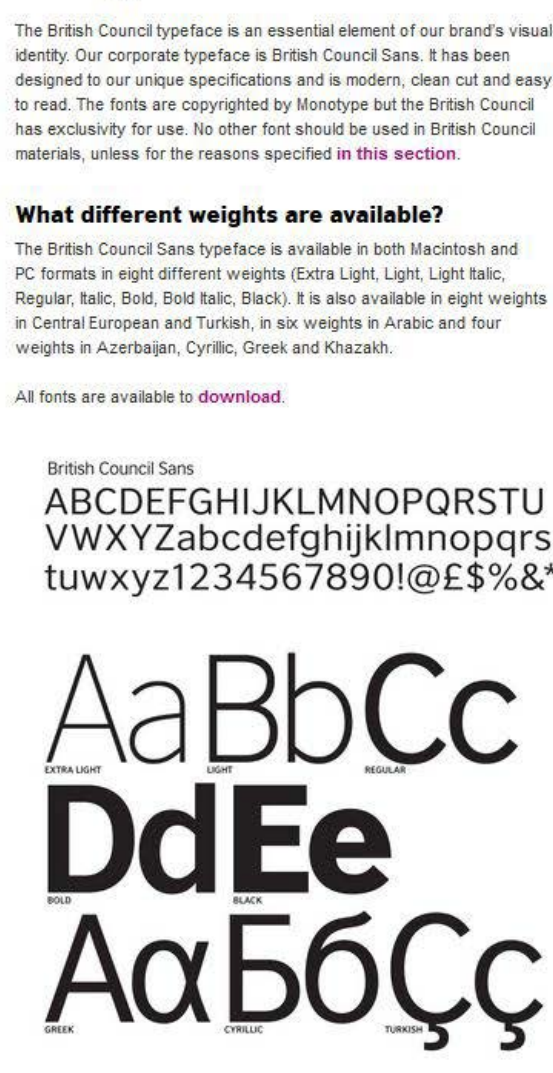

Extra Light Light

\section{Regular Bold Black}

1.4.4 British Council Diferentemente da maioria dos manuais de

30 Identidade Visual e brand books, que se limitam a mostrar as famílias tipográficas institucionais, este $в$ в aprofunda a descrição de suas fontes e as regras de uso. As diretrizes de estilo para a identidade desta organização internacional para relações culturais apresenta seu вв inteiramente em um website e agrega um panorama tipográfico bastante completo e detalhado (FIGURA 019).

A marca Brithish Council é definida pela combinação de três elementos principais: o posicionamento da marca (brand framework), com destaque
FIGURA 019_Página do site que apresenta a fonte British Coucil Sans e suas versões. 


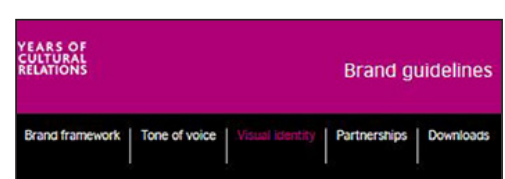

Typography checklist

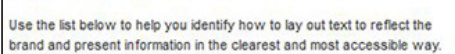
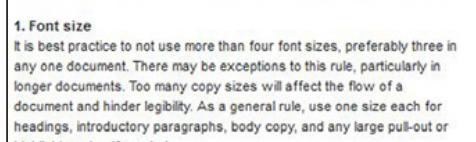

2.teating anc kereming

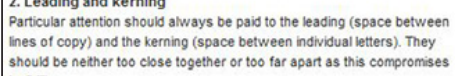

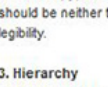

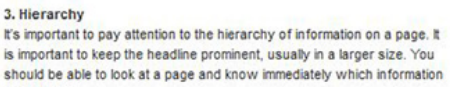

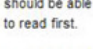
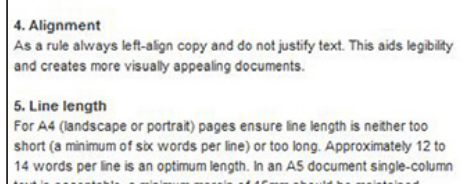

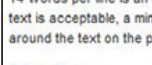

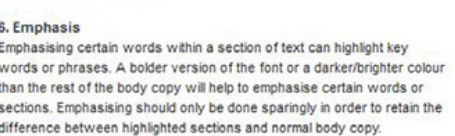

.renctobur

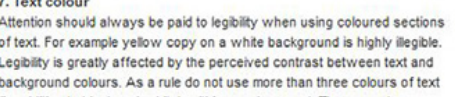

FIGURA 020_Pagina do brand book que apresenta recomendaçōes de uso da familia tipográfica, na forma de uma lista de checagem, para que a tipografia reflita da melhor maneira a identidade da instituição.

para os valores, personalidade, o valor da marca a mensagem e sustentabilidade; um "tom de voz", orientações sobre a linguagem verbal, escrita ou falada nos aspectos gramaticais, ortográficos e questões editoriais; e as guias da identidade visual. Nesta última, 16 itens são detalhados em sua forma de uso e aplicação com possibilidade de acesso a arquivos de gabarito (templates). De modo geral, tratam da marca, tipografia, estilo fotográfico, aplicações gráficas, aplicações efêmeras, sinalização e mídias digitais. Dois itens se referem à tipografia: a fonte British Council Sans e orientações para aplicá-la ao design. No item dedicado ao manejo da tipografia além de mostrar bons e maus exemplos de uso da fonte em cartazes, folhetos e páginas editoriais, sugere um lista com sete itens para que a composição do texto apresente a informação do modo mais claro e objetivo além de refletir as ideias da marca. São eles: (1) corpo da fonte; (2) entrelinhas e kerning ${ }^{12}$; (3) hierarquia; (4) alinhamento; (5) comprimento de linha de texto; (6) ênfase; (7) cor do texto (FIGURA 020). O manual ainda dispõe de orientações de acessibilidade, preocupado em alcançar seu público da melhor maneira, em particular, a parcela que apresenta necessidades especiais. São sugestões de tratamento tipográfico do texto para obter maior clareza e objetividade possível, como o uso de corpos maiores, atenção ao contraste (letra/fundo) e ao peso das letras, evitando o uso excessivo de 20 tipos muito leves, cuidado com as margens e colunas, dicas para facilitar a navegação na página e materiais mais adequados para impressão.

O manual considera sua fonte corporativa um elemento essencial para a identidade visual da instituição, descrevendo-a como moderna, limpa, de fácil leitura, e afirmando que deve ser usada obrigatoriamente em todos os materiais de comunicação, excetuando os casos em que a transferência de documentos podem provocar substituições indesejadas, utilizando para esses casos a fonte Arial.

O design é de propriedade da type foundry Monotype ${ }^{\bullet}$, mas os direitos de uso são exclusivos. A fonte tem oito estilos para o alfabeto romano (Extra Light, Light, Light Italic, Regular, Italic, Bold, Bold Italic e Black), oito estilos para alfabetos do centro europeu e turco, seis estilos para o árabe e quarto outros para grego, cirílico, cazaque e azerbaijano. É um tipo sem serifas, altura-de-x alta, contraste entre as hastes quase nulo, terminações

12 Kerning: ajustes do espaçamentos entre um par específico de letras incluídos no programa de uma fonte, para equilibrar os espaços brancos internos e externos em relação às outras letras quando compostas em uma palavra inclinadas nas curvas com características muito próximas às das grotescas do início do século xx como News Gothic (1909) de M. Fuller Benton e semelhante a muitas outras fontes que seguem o mesmo princípio de estrutura e design, como o próprio manual reconhece. A intenção de proporcio5 nar um campo de reconhecimento da marca nas comunicações em que a marca não está presente aparece na tentativa de auxiliar o usuário a identificar a fonte, propondo um painel com algumas características que

\section{BRITISH}

\section{How to recognise British Council Sans}

British Council Sans has been designed to our unique specification and is our mandatory typeface on all printed materials. Although it may look ways you can tell British Council Sans from other typefaces.

British Council Sans has been designed to be clean cut and easy to read. It has a large ' $x$ ' height (the height of lowercase letters, specifically $x$ ) which is designed to make it easy to read and also helps distinguish it from other typefaces. The example letters below show how you can easily recognise British Council Sans by comparing it to other typefaces.

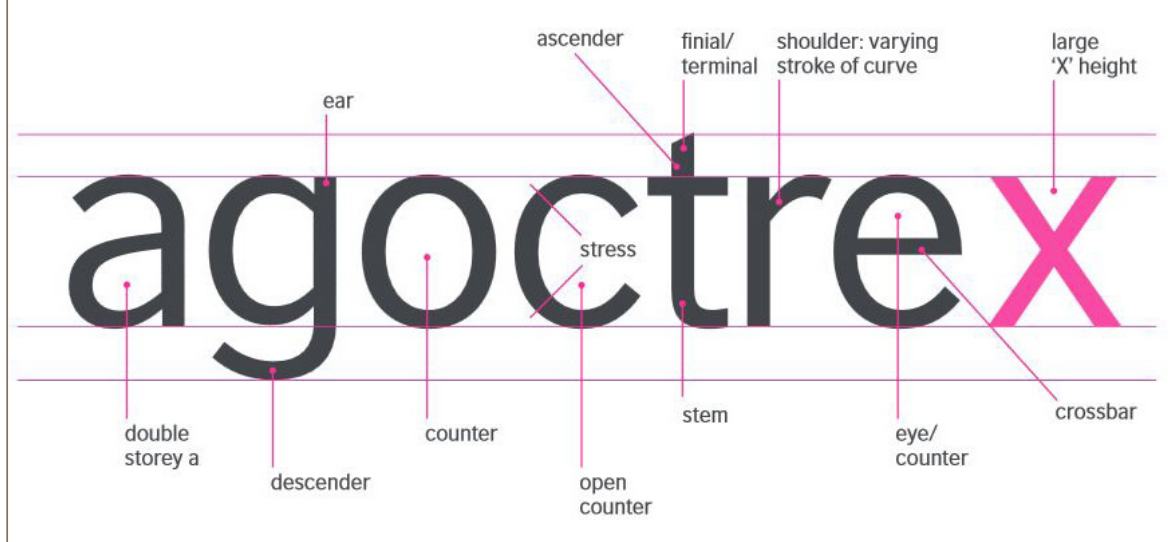

distinguem suas letras (FIGURA 021). Compara, por exemplo, os caracteres 'a, t. g, r. o, e, c. ق̈' (caractere árabe Qaf) da British Council Sans aos das fontes Century Gothic, Bliss, Helvetica, Arial e Verdana; e para cada letra comparada, são assinalados os detalhes que diferenciam e identificam a 35 fonte institucional.
FIGURA 021_Quadro demonstrativo das particularidades da fonte British Council Sans, auxiliando os usuários a diferenciá-la de outras fontes sem serifa. 
1.4.5 Governo Federal Alemão (Die Bundesregierung)__ Este manual, elaborado em 2010 e disponível on-line em arquivo digital na web, está dividido em duas partes: mídias impressas; e mídias on-line. A tipografia também é destacada juntamente com os principais elementos da marca. Segundo o texto introdutório do manual, a tipografia é caracterizada pela clareza, concisão e máxima legibilidade, permitindo uma fácil utilização em qualquer mídia. Atende os requisitos técnicos que a tornam portáveis entre diferentes plataformas (cross-media) e garante um aspecto moderno e contemporâneo ao governo federal alemão. A família é formad por dois estilos básicos: a BundesSerif; e a BundesSans (FIGURA 022 e 023), ambas nos estilos regular, medium e bold com seus respectivos itálicos.

\section{Search}

FIGURA 022_Fragmento do portal noticias do website do Governo Federal Alemão mostra o uso alternado das versões serifada e sem serifa em favor da hierarquia visual das informações.

JKRAINE CRISIS

Working together for peace

Chancellor Angela Merkel has called on Europe to present a united front. This is crucial in order to overcome the crisis in Ukraine and enforce the strength of the law, she said.

As fontes são usadas tanto em materiais impressos como no website. O conjunto é complementado pelas fontes Univers 57 Condensed, Arial Narrow e Times como opções alternativas para os casos em que a famí lia Bundes não esteja disponível. O projeto foi conduzido pelo escritório MetaDesign e a autoria das fontes é de Jürgen Huber e Martin Wenzel.

Como a comunicação governamental é centrada em mensagens textuais, o design corporativo precisa ter uma linguagem visual clara coesa. As fontes dão ao design uma aparência uniformizada, integrando-se à paleta de cores e a um design objetivo e flexível que é replicado em diversas mídias. Em entrevista cedida ao site Typografie.info ${ }^{13}$, os designers afirmam que tinham a premissa de criar um olhar contemporâneo, mais ágil e aberto. Atributos mais subjetivos como simpatia imponência e elegância também orientaram o projeto. Mais estilos deveriam compor a família (BundesSerif Web e BubesSans Web) para aten-

13 Typografie.info. http://www.typografie.info///page/artikel.htm/_/interviews//bundesserif-bundessans>

der as necessidades cross-media por isso o formato das fontes mudou de PostScript Type 1 para Open Type, prevendo a flexibilidade desse formato e reduções de custo com licenças. As versões serifada e sem serifa foram projetadas simultaneamente para que a coerência entre

o5 elas fosse assegurada. Enquanto a BundesSerif carrega os traços de tipos do século Xv com contraste médio eserifas triangulares que remetem à caligrafia, a BundesSans é uma fonte neo-grotesca que igualmente incorpora resquícios de um traçado caligráfico nas letras 'b, l', com aberturas amplas em 'a, c, e, s' e sem contraste significativo.

manual define também como as fontes devem ser usadas em peças gráficas estabelecendo regras precisas de tamanhos de página, corpos das letras, alinhamentos e posicionamento na grade básica. A fonte BundesSerif é preferencial para títulos e no corpo de textos longos. A BundesSans é usada em subtítulos, legendas, tabelas e infográficos.

15 Tratando-se de um órgão governamental, a família Bundes converge para a tradição tipográfica europeia e a contemporaneidade. $\mathrm{O}$ uso alternado da versão serifada com a sem serifas, associado a um plano de design racional e arejado, cria uma unidade visual equilibrada e unificada apropriada ao seu propósito (FIGURA 023).

4.6 Manuais do escritório Cauduro \& Martino Um dos escritórios de design pioneiros do Brasil, constituído pela dupla de arquitetos formados pela FAU-USP João Carlos Cauduro e Ludovico Martino, foi fundado em 1964 e desarticulado em 2014. Adeptos da linguagem construtiva moder-

nista, foram responsáveis pela criação de identidades de organizações bancárias, industriais e governamentais. Nos 14 manuais consultados ${ }^{14}$ fica evidente a predileção pela família Univers, seguida por Helvetica, Eutura e Times New Roman. A estrutura dos manuais segue um padrão que foi apenas modificado mediante as peculiaridades de cada empresa.

30 O alfabeto padrão, termo pelo qual estes manuais se referem, está agrupado juntamente com as especificações da marca e cores padrão, seguido pela aplicações da marca em materiais gráficos impressos e de sinalização. De todos os exemplares, destacam-se o manual e descritivo para o metrô de São Paulo pela natureza e protagonismo da tipografia dentro do sistema. 14 Em julho de 2014, o designer earquiteto paulistano Joäo Carlos Cauduro doou para o autor desta dissertação 14 cópias de Manuais de Identidade produzidos pela Cauduro/Martino, compreendendo o período de 1972 a 2001.
Deutschland

Mitgliedstaaten

DIE KANZLERIN

Energiepolitik

- 1029384756

$\rightarrow$ Anwenderinnen

Windows \& Mac

1029384756

Demokratisch

Grundgesetze

$\rightarrow$ Entscheidung

1029384756

Bundesregierung

Bitte beachten!

1029384756

DER BUNDESTAG

FIGURA 023_Amostra da tipografia Bundes Sans e Bundes Serif, ressalta a semelhança da estrutura básica entre os dois estilos. 
FIGURA 024_Redesenho da tipografia Univers Bold 693 executado pela Cauduro e Martino em 1972.
Apenas quatro anos após a formação do escritório, os designers foram convidados para planejar o programa visual do Metrô de São Paulo, um projeto que tramitou de 1967 a 1970. Além da famosa marca simbolizada pelas duas setas opostas, o escritório cuidou da criação do sistema de sinalização e orientação do fluxo de pessoas. Para formar a base de toda a comunicação, foram definidos pictogramas, um código cromático, mapas informativos e, particularmente, um alfabeto padrão para a composição de todas as mensagens verbais do sistema. Notadamente adeptos de uma paleta tipográfica essencial, adotaram o tipo Univers bold 693, um estilo da série de tipos móveis de metal, em caixa alta e baixa, depois de terem experimentado os tipos Helvetica, Folio e Transport. Segundo consta no detalhamento descritivo dos principais elementos e normas de organização do Sistema de Comunicação Visual do Metrô de São Paulo (1972), as

\section{ABCDEFGHI JKLMNOPQ RSTUVWXY \\ Z \\ !? ()}

abcdefghijk! mnopqrstuv

$$
\mathbf{W X Y Z} \text {, , : }
$$

razões que levaram à escolha da série Univers foram: (1) estéticas, devido à positiva variação das espessuras dos traços; (2) técnico-operacionais, pois as terminações das letras são todas verticais ou horizontais, o que permite maior precisão na produção e montagem das mensagens verbais; e (3) versatilidade: variedade de estilos, romano e itálico, pesos light, medium, bold e extra-bold, o que favorece a uniformidade das mensagens, fundamental para a imagem do sistema do metrô (CAUDURO, 1972, vol. 1:16).

Cauduro relatou que, na época, a aquisição do alfabeto Univers era problemática no país, sendo forçado a desenhar o peso bold manualmente a - partir da versão medium disponível em uma publicação (LONGO JR., 2007:54). A partir dessa referência, o peso bold foi ajustado (FIGURA 024). Comparando a Univers Bold 693 com a versão digital da Univers Bold 65 (Linotype ${ }^{\odot}$ ), a primeira é cerca de $3 \%$ mais pesada e as terminações são simplificadas, por exemplo, o remate curvo da parte inferior da haste do 'a' que na série $693 \mathrm{fo}$

eliminado (FIGURA 025). As letras foram desenhadas e fotografadas individualmente, gerando filmes em negativo, emoldurados como slides, em um processo similar ao das fotoletras ${ }^{15}$. A partir dessas matrizes fotográficas, as palavras eram

compostas e ampliadas em tamanhos definidos. As palavras, ou os signos nominativos, eram aplicados em suportes descritos como "faixas contínuas de informação, compostas por lâminas de

fórmica branca fosca que, durante sua produção e antes do acabamento final, recebiam as mensagens impressas em

silkscreen em um papel branco, sobre o qual se depositava a última camada de melanina permitindo a prensagem do conjunto sem deixar, contudo,

3o o calor oriundo do processo danificar as informações" (LONGO JR., 2007:56). Todos os textos do sistema de sinalização foram padronizados em quatro tamanhos padronizados para facilitar, acima de tudo, a produção e aplicação das letras, tomando como referência a altura da letra 'l' caixa alta (FIGURA 026). Os tamanhos são $15 \mathrm{~cm}, 10 \mathrm{~cm}, 5 \mathrm{~cm}$ e $3,5 \mathrm{~cm}$, considerando

15 Fotoletras: sistema de composição tipográfica a frio, que utiliza meios fotográficos, a partir de matrizes selecionadas manualmente, para gravar as letras em emulsão fotográica (filme ou papel) para aplicação em artes finais. 


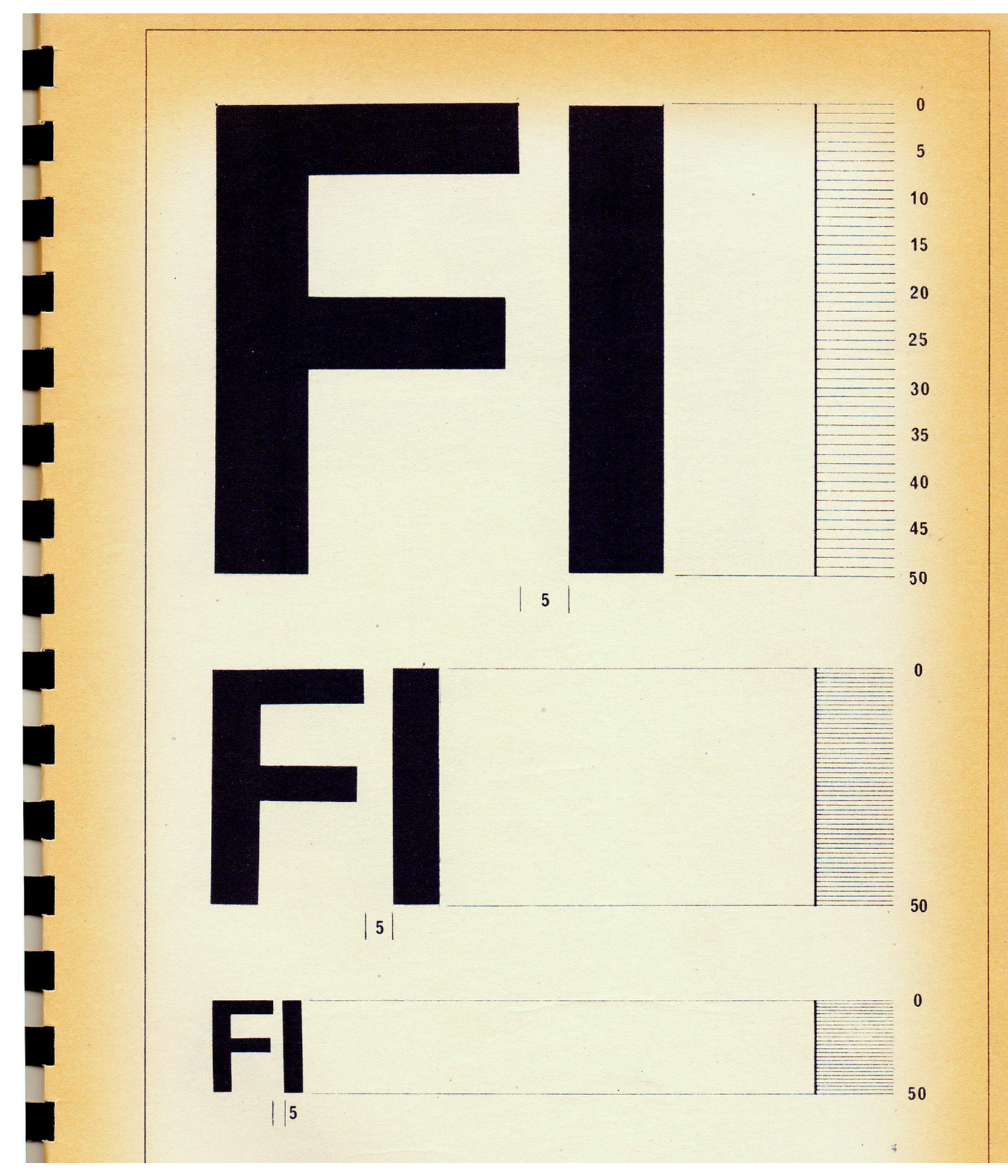

FIGURA 026_ A planificação do módulo de fracionamento métrico de 1/50 para definição de alturas padronizadas e espaçamentos. limite para leitura uma distância de 90 m, 60 m, 30 m e 21 m respectivamente Como as letras se comportam diferentemente em tamanhos distintos quando lidas a distâncias variáveis, um minucioso trabalho de ajuste do espaçamento

05 das letras foi realizado para garantir a correta leitura padronizar os critérios de montagem das mensagens verbais.

$O$ ajuste partiu de um pressuposto meramente visual intuitivo da percepção das formas e contraformas, ou seja, espaços brancos e pretos das letras (CAUDURO, 1972, Vol.1:18), Dessa análise, foi estabelecido um "módulo de espaçamento" correspondente a $1 / 50$ da altura do alfabeto. Definido esse módulo, Cauduro criou classes de espaçamentos para as formas retas com retas, formas retas com curvas, meias-curvas
Bilheterias

\section{Telefones}

\section{Telegramas}

\section{Sanitarios M}

tabela de valores de espaçamento incluem os parâmetros para a caixa alt caixa baixa, algarismos, pontuação, outros sinais de marcação e todas as possibilidades de combinações entre todos eles. O módulo também serve para determinar espaços entre palavras (FIGURA 027) e as relações entre as letras e os sinais direcionais e pictogramas Impressos em tamanho real de combinações de letras já espaçadas pelas normas estabelecidas foram analisados em situações efetivas para testes de funcionalidade e logibilidade (FIGURA 028).

Nesse extenso e completo manual, o fator mais importante não é apenas a escolha de uma tipografia de suposta neutralidade e objetividade. Toda a rígida estruturação do sistema informativo levou em consideração as necessidades, conteúdos e localização das informações, a aplicação em suportes padronizados,

tendo como objetivo principal comunica inequivocamente a um público extremamen diverso nas escalas social e cultural. 2TQVOX BA5B56 305474071R3R4R5R 36737681R8R9S1S $0556575354 S 5 S 6$ ¡9506676 S8S9T1T2 8393042 P3P4P5P ¿BOCOJ $1 \mathrm{~B} 12 \mathrm{~B} 23$
FIGURA 027_Especificação dos espaçamentos entre letras para métricos.

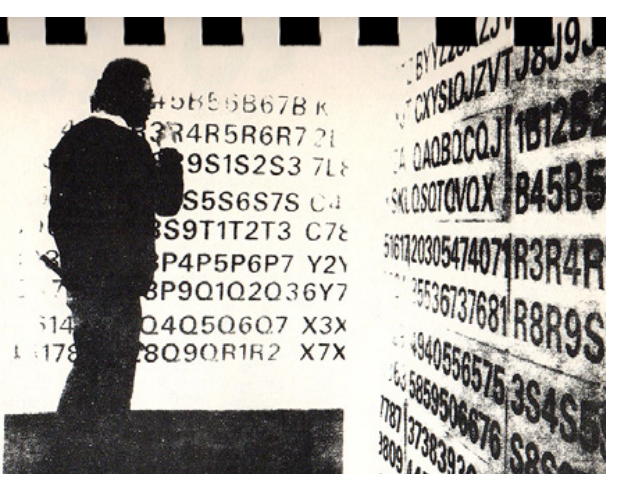

FIGURA 028_Testes de legibilidade do alfabeto em tamanho e si
ambiental real. 


\section{O CARÁTER DOS CARACTERES}

Entre as motivações que estimulam a produção de fontes proprietárias que oferecem exclusividade e dão controle total sobre o seu uso, as instituições também almejam que essas tipografias tenham um caráter único e consigam se integrar à sua identidade visual, personificando

10 seus valores e posicionamento na sociedade e no mercado em que atuam Esses tipos são projetados especificamente para alcançar todos esses propósitos e seu design pode incorporar traços expressivos que reflitam a identidade corporativa.

15 2.1 AS CONEXÕES COM O TEMPO E A NACIONALIDADE Aideia de que os desenho dos caracteres pode portar mensagens visuais não recente. As letras capitulares romanas, associadas ao império, nas letras inscritas sem serifa gregas, relacionadas à república, já apontavam para isso e o curso da história segue com as góticas germânicas Fraktur, os

20 tipos renascentistas italianos de Manutius e a francesa Garamond, depois as Bodoni e Didot (BRUMBERGER, 2003a:207). Para Lawrence Mirky (1998), a tipografia ocidental sempre esteve conectada com o momento cultural, religioso ou político de seu tempo, relacionando a história da tipografia com a teoria social do orgânico e a teoria espiritual do cristalino. Para ele, as

25 letras góticas alemãs são percebidas nos termos do orgânico e da natureza do "povo", em que a herança romântica dos tipos Fraktur é associada à ideia de infinito herdada dos Godos. Já o neoclassicismo francês e "artificial" dos tipos Didot está ligado ao ideal grego de finitude, cujas qualidades mais geométricas e luminosas se relacionam à ideia do cristalino (MIRSKY

30 1998:6). O autor ainda compara as formas orgânicas presentes na transição do Iluminismo para o Romantismo com a criatividade e mutabilidade da natureza humana. O tipógrafo Jan Tschichold (2001), no artigo The Principles of the New Typography (1928), em que trata da expressividade dos tipos, ressalta a relação entre momentos culturais e o design tipográfico

35 ao afirmar que as ideias e conceitos da forma são transferidos ao caráter dos diferentes tipos de letra, de acordo com cada período da história. Ele exemplifica: “Se Didot fez algo diferente de Fleischmann, foi porque os 
tempos haviam mudado, e não porque ele quisesse produzir algo 'especial', 'pessoal' ou 'único'. A concepção de como uma boa tipografia deve ser simplesmente havia mudado" (TSCHICHOLD, 2001:123— tradução minha $a^{16}$ ).

Essas mudanças se intensificaram nos séculos seguintes. $\mathrm{O}$ crescimento qualitativo e quantitativo dos tipos durante o período da Revolução Industrial do século XIX e início do século xx podem ser correlacionados tanto aos movimentos de expansão territorial de países europeus em busca de novos mercados, que colocaram a Europa em contato direto com outras culturas, como à multiplicidade de escolas e movimentos artísticos e literários que ocorriam simultaneamente (BRINGHURST, 2005:146), não esquecendo as novas descobertas e avanços científicos e tecnológicos. Para o autor, tais acontecimentos tiveram ressonância imediata no universo tipográfico. Um panorama bastante claro dessa diversidade é verificado, por exemplo, nos cartazes do período vitoriano inglês em que vários tipos de diferentes estilos e tamanhos coexistem em uma composição repleta e centralizada, refletindo o espírito da época, ou o zeitgeist ${ }^{17}$. Muitos desses cartazes podiam usar até nove tipos diferentes (FIGURA 029), e possivelmente até mais do que isso. Contudo, apesar da abundância de formas, a maioria dos tipos converge para uma linguagem dura, impositiva, informativa e direta. Bringhurst chama essa nova maneira de conceber o design dos tipos de "realismo tipográfico", em que as referências da escrita caligráfica culta é substituída pelos traços com espessura mais homogênea ou com modulação dos traços (contrastes) exagerados, serifas grossas e com pontas quadradas ou sem nenhuma serifa, construções excêntricas e adornadas, ignorando qualquer sinal de elegância e sofisticação (Ibid.:147).

A expressividade dos tipos contemporâneos reforça a tese de que a tipografia é reflexo de um tempo e de uma cultura no sentido mais amplo. De acordo com Ladislas Mandel (2006), a história da escrita deixa evidente que a postura do escriba, com seu gestual, atitude e espírito, conferia às formas das letras uma marca pessoal e da cultura à qual pertencia, delimitando um registro bastante específico. Ele se recusa a

"If Didot did something diferent from Fleischmann it was because times had changed not betise he wanted to produce something 'special', 'personal' ou 'unique'. The conception of what a good typeface should look like had simply changed" (TscHICHOLD, 2001,1233).

17 Zeitgeist: espííito de um período particular da história representado pelas ideias, crenças etc. do tempo (OXFORD, 1992:1058).

\section{GRFAT LIGT FAlimi, UPTON PYNE,}

ABOUT THREE AND A HALF MILFS FROM EXETER. 200 Devon Longwool Sheep and Lambs, 6 Rams, 24 Bullocks, 8 Cart Horses and Colts, 43 Pigs, Hay, Implements, Geese, Hard and Faggot Wood, \&cc.

\section{HUSSEY \& SON} ON TUESDAY, 15TH SEPTEMBER, 1891.

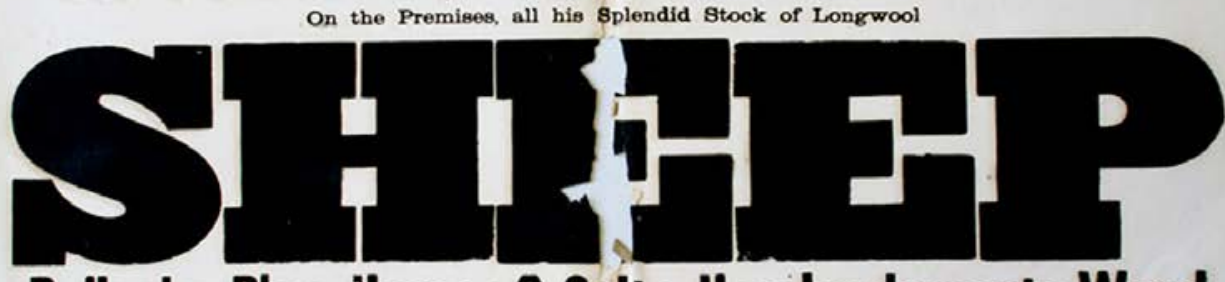

Bullocks, Pigs, Horses \& Colts, Hay, Implements, Wood,

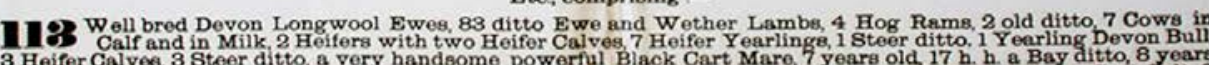

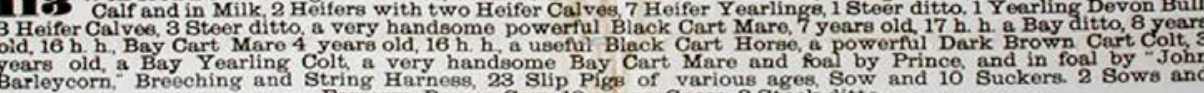
Six Ricks of well saved Clover and Meadow Hay made in 1889, 1890 and 1891, in all about 70 tons. IMPLEMENTS

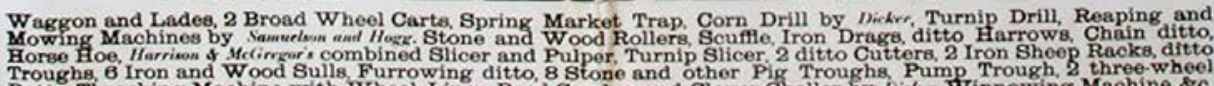
About 30 TONS of HARD WOOD in Lots, 2 Picks of FAGGOT WOOD.

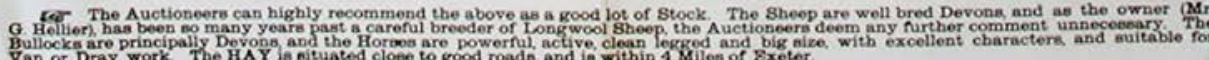

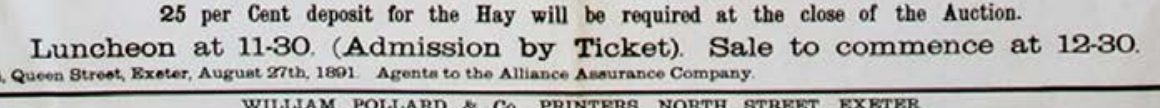

GURA 029_Cartaz de 1891 que divulga o leilão de uma fazenda. Peça da coleção do Centre for Ephemera Studies do Departamento de Tipografia e Design de Comunicação da Universidade de Reading, Inglaterra. 
aceitar, por exemplo, que a escrita cuneiforme dos sumérios tenha desenvolvido sua estrutura, baseada em cunhas triangulares, pela simples limitação tecnológica ou instrumental. Quando a produção de tipografias em escala industrial passa a difundir tipos locais em um universo mais amplo, as particularidades e sutilezas que o design dos tipos pode operar 05 ficam diluídas na comunicação de massa: "Atualmente assistimos a uma proliferação sem precedentes de escritas que não têm nenhuma ligação nem com as culturas, nem mesmo com as funções particulares do escrito, refletindo bem a confusão do mundo moderno" (MANDEL, 2006:18).

Tschichold (2001) aponta na mesma direção: “Todos os letreiramentos 10 (letterings), especialmente os tipos, são antes de tudo uma expressão de seu tempo, assim como todo homem é um símbolo de seu tempo" (TSCHICHOLD, 2001:122). Nos anos 1920, a Nova Tipografia pretendeu eliminar qualquer registro de nacionalidade, criando tipos mais racionalizados e livres de associações históricas ou culturais (BRUMBERGER, 2003a:207) e, apesar dos esforços em "esterilizar" o desenho das letras, esse racionalismo resultou em uma expressão própria e muito presente, e os designers signatários dessa visão aceitaram que os tipos têm personalidades (personas) distintas, e que nunca poderão perder seu impacto retórico (Ibid.).

\subsection{MEMÓRIA E A REAÇÃo EMOCIONAL Às FORMAS}

TIPOGRÁFICAS Em um sentido mais prático, porém muito mais subjetivo e impalpável, o aspecto visual de uma tipografia e o efeito de sua percepção criam uma resposta emocional no leitor. Essa relação tem ligações com a legibilidade e com os fatores internos e externos que atuam sobre ela, influências culturais e idiomáticas e outras condições ainda mais particulares de um grupo de indivíduos. Para Moen (2000:119), em uma época em que a informação é amplamente conduzida pelo texto e consequentemente, pela sua forma visual tipográfica, é importante que o leitor seja, de alguma forma, guiado através da imensa quantidade de 30 informação disponível e direcionada para ele. Portanto, a escolha das fontes deve obedecer a critérios de legibilidade, de sua imagem conotativa, sua credibilidade e estar conectada ao tipo de comportamento e repertório visual da comunidade à qual a mensagem é destinada. Mandel (2006:171) nos lembra que elementos expressivos e emocionais 35 fazem parte de cada traço das letras, sejam estas tipográficas ou manuscritas. Esses elementos integram uma linguagem que se sobrepõe ao o1 significado do texto, ambos percebidos e compreendidos pelo leitor. Para que a tipografia possa exercer seu potencial de expressão, é necessário ser mais "vista" do que "lida". Estudos sobre a memorização de anúncios publicitários têm direcionado suas atenções para a estreita relação entre

o5 as porções pictórica e a verbal, especialmente para o potencial das qualidades gráficas desse material verbal (CHILDERS e JASS, 2002:96), ou seja, as particularidades das formas tipográficas. Esse pensamento é compartilhado por Stöckl (2005) quando cita a palavra alemã schriftbild (typeface, tipografia) ou, a síntese de escrita + imagem, que simboliza a capacidade

dos leitores em abstrair a função linguística da escrita e focar em suas qualidades pictóricas, ignorando a simbologia das letras e percebendo o texto como uma superfície projetada (STÖCKL, 2005:206).

Peter Walker (2007:3) afirma que as palavras são codificadas de diferentes maneiras durante a leitura. A percepção e o reconhecimento das

15 formas tipográficas são processados pela conexão entre as estruturas elementares das letras, as chamadas estruturas subjacentes, e as informações guardadas na memória visual de longo prazo (MVLP). Durante o processo dessa conexão entre o estímulo visual e os códigos armazenados, experiências podem ser ativadas, que emergem ao nível consciente 20 (RÖGENER et al, 1995:14) gerando respostas emocionais ao estímulo, ou, no caso, às formas específicas e particulares das letras. Moen menciona o tipógrafo Will Burton, para quem a memória visual tem um poder maior de retenção e elaboração cognitiva dos sinais porque

25 Quando ouvimos uma mensagem ela é logo esquecida, mas aquela que vemos e lemos é mais permanente porque penetra na memória em mais de um nível e pode ser acessada por várias vezes. Isso explica a crescente importância da tipografia como uma ferramenta corporativa mundial - uma ferramenta que devemos melhorar constantemente, estudando-a e usando-a (BURTON apud MOEN, 2000:117 - tradução minha' ${ }^{18}$ )

18 "A message that we hear is soon forgotten, but the one that we see and read is more permanent because it penetrates memory on more than one level and can be referred to over and over again. This explains the steadily by studying it as we use it' (BURTON apud MOEN, 2000:117 
Moen (2000:126) entende que as experiências e o repertório cultural do designer e do leitor determinam aquilo que se apreende em um design tipográfico e, se os elementos expressivos dos tipos forem usados com precisão, atraem a atenção, criam modulações na voz do texto transformando meros "escaneadores" em leitores de fato. As avaliações e 05 subsequentes ações do designer, durante seu processo criativo e operacional passam, inevitavelmente, por momentos de absoluta subjetividade e podem estar sujeitas a emoções circunstanciais ou pura intuição. Rolf F. Rehe (1976:13) acredita que o texto impresso em um tipo "agradável" atrai mais o olhar do leitor do que outro impresso em um tipo "entediante" e pouco atrativo. Evocando o papel do tipógrafo como um comunicador de massas, o autor ressalta que a tipografia contribui para determinar a percepção, seleção e compreensão da mensagem, definindo se a mensagem será lida e como será lida (Ibid..15). Outro aspecto disso, segundo o tipógrafo e pesquisador holandês Gerrit Willem Ovink (1938) é o fato de esses sentimentos (agradar ou desagradar) influenciarem na percepção imediata, na força das associações e na qualidade da memorização do objeto. Do ponto e vista fisiológico quando somos expostos a letras, palavras ou textos inteiros, reagimos de maneira subconsciente aos menores estímulos visuais que o design dos 20 tipos nos apresentam, o que é diferente dos julgamentos que fazemos a respeito de beleza ou legibilidade (ovinK, 1938:127).

A grande variedade de formas, que a tipografia tem adquirido nas últimas décadas, é regida por códigos próprios baseados na combinação de seus elementos (serifas, peso, contraste, curvas, remates, ritmo, adornos) que são completamente independentes do conteúdo transmitido pelas mensagens (oviNK, 1938:127), mas que podem convergir para uma condição comum e integrada por meio do controle do designer. Algumas tipografias, como Times New Roman e Helvetica, produzem respostas mais impessoais por serem muito usadas para qualquer 30 propósito, ou também por serem relacionadas a certos temas, comportamentos ou produtos, como notícias, documentos administrativos e publicidade. Portanto, a particularização, no caso de uma tipografia corporativa, evita que uma mensagem grafada com tipos já existentes e usados com muita frequência não seja interpretada como um caráter de individualidade que, em muitos casos necessita ter. A exemplo do que ocorre com qualquer produto cultural, que, de ol algum modo, está sujeito ao "consumo", os fatores que influenciam a preferência por um ou outro estilo ainda são objetos de estudo. Uma possibilidade aponta para um "gosto comum", suscitado pela exposição constante a um determinado tipo de letra, que se torna parte

05 do repertório visual dos indivíduos, criando uma relação emocional. Portanto, um design tipográfico só pode ser avaliado em seu caráter de representatividade e de qualidade, se for analisado em uma perspectiva de longo prazo (LEONIDAs, et al. 2012:50), ou porque se consolidou ao se associar a um evento que obteve repercussão ou uma marca

1. forte, ou por capturar o espírito de seu tempo e terem sido usado repetidamente, tornando-se um paradigma para situações ou temas mais específicos.

\subsection{PESQUISAS SOBRE OS "VALORES EMOCIONAIS"}

15 “ATMOSFÉRICOS" DA TIPOGRAFIA As tentativas de estudos pesquisas para qualificar e quantificar as características emocionais do tipos partem de, principalmente, três métodos de testes que envolvem ao menos 100 entrevistados. De acordo com Rehe (2007: 56), são: classificação qualitativa, em que entrevistados confrontados com cerca de 10 tipos

20 diferentes fazem escolhas intuitivas sobre a adequação ou inadequação dos tipos dispostos em um mesmo design; apresentação de questionário em que diferentes aspectos expressivos dos tipos são testados, como o comportamento de leitura, a percepção do tipo, o conhecimento sobre o tipo, etc. Também uma amostra de tipos de letras pode ser apresentada

e as questão podem ser com que tipo de mensagem o entrevistado relacionaria o tipo de letra ou em que espécie de revista que gostaria de lê-lo; por diferencial semântico, um método que mede conotações emocionais, em que entrevistados escolhem atributos de uma lista de conceitos ou adjetivos opostos, como forte ou fraca, delicada ou rude, assim por dian-

30 te, e atribuem valores numéricos a eles. Os resultados são apresentados em tabelas de valores obtidos por análise estatística.

Os estudos e testes publicados a esse respeito abordaram o conceito de "valor atmosférico" (atmosphere-value ou feeling tone), "congenialidade", "alusão tipográfica" ou "personalidade tipográfica" dos tipos, termos que 35 se referem à capacidade de uma característica ou estilo tipográfico de conotar significados linguisticamente comunicados pelas palavras (LEWIS e WALKER, 1989:243). Para Ovink (1938:127), são as "propriedades 
FIGURA 030_Tabela referente à classificação da tipografia Bodoni Bold no experimento realizado por Poffenberger e Franken, em 1923. Curiosamente, este tipo foi julgado inapropriado para 'luxo', jóias' $e$ 'perfume', contrariando o que ocorre nos dias atuais. pelas quais os tipos provocam sensações no leitor". As primeiras pesquisas foram realizadas em 1920 por Anna Berliner que investigou o valor atmosférico de 18 letreiramentos associados á commodities, como peixe, porco e feijões, farinha de panquecas, geleia de laranja. Cada commodity recebeu um valor que mediu sua correlação com cada tipo de letra apresentado. Em 1923, Poffenberger e Franken (1923:315) determinaram a adequação de 29 tipografias frequentemente usadas em anúncios publicitários para cinco qualidades abstratas: custo baixo, dignidade, economia, luxo e força, também associadas a cinco commodities automóveis, material de construção, café, joias e perfume. Grupos de homens e mulheres foram submetidos separadamente ao teste para detectar a influência do gênero nas análises. Cada uma das 29 tipografias recebeu uma pontuação para cada elemento das duas categorias, de acordo com o grau de adequação, sendo o valor 1 para mais apropriada e 29 para menos apropriada (FIGURA 030).

\section{WHEN, IN THE COURSE OF HU:}

\section{B man events, it becomes necessary}

\section{for one people to dissolve $\$ 12345 \&$}

\section{Cheapness \\ Dignity \\ Economy \\ uxury \\ Strength}

$\begin{aligned} \text { B-Bodon } & \text { Bold } \\ 7 & \text { Automobıles } \\ 17 & \text { Buldıng Material } \\ 9 & \text { Coffee } \\ 16 & \text { Jewelry } \\ 9 & \text { Perfume }\end{aligned}$

6

Outros estudos, como o de R. C. Davis e H. J. Smith, em 1933, procuraram determinar o efeito no sentido do tom emocional (feeling tone) das variações das características mecânicas de um mesmo tipo, ou seja, as variações de peso (bold, light), condensação, expansão, itálicos e tamanho. Foram usados 13 tipos associados a 23 produtos e 24 valores emocionais. Ovink (1938:135-177) também empreendeu pesquisas sobre o assunto, aprofundando a questão na direção dos tipos usados em textos longos de livros. Em seus testes, textos genéricos compostos em 38 tipos diferentes foram apresentados aos participantes e lhes foi pedido para associarem a atmosfera dos textos a uma lista de adjetivos fornecida:
1. Francês, alemão inglês, americano, holandês, neutro:

2. Agradável, desagradável, neutro;

3. Legível, ilegível, neutro;

4. Elegante, deselegante, desajeitado, imponente, honrado, ruidoso, insolente, prático, romântico, enérgico, grosseiro, confiável, extravagante, arejado, espirituoso, delicado, cortês, ordinário, confortável moderno, antiquado e preciso.

Depois, os participantes escolhiam um título de livro (de uma lista fornecida) que combinasse melhor com cada texto.

Uma outra parte da avaliação, utilizou 48 tipos para títulos (display) e os participantes também deveriam escolher títulos de artigos que melhor anunciassem a tipografia em questão. Em outra fase de testes, três grupos de questões foram submetidas a 70 participantes: o primeiro, inquiria simplesmente sobre a legibilidade; o segundo relacionava 38 tipos apropriados para textos de livro que foram associados a oito temas literários:

1. Romance, aventura:

2. Técnicas modernas e arquitetura;

3. Estilo de vida rude de fazendeiros:

4. Tragédia clássica e imponente;

5. Sátira espirituosa;

6. Análise objetiva de problemas culturais

7. Relatórios práticos:

8. Poemas sensíveis e delicados;

Um teste complementar relacionou a adequação das mesmas 38 tipografias, acrescidas de outros 17 tipos para títulos, que deveriam ser associados a oito conceitos:
1. Vigor, força;
5. Precisão, delicadeza;
Economia, sobriedade;
6. Higiene, frescor;
3. Luxo, refinamento;
7. Confiabilidade, solidez
4. Distinção, dignidade;
8. Calidez, conforto 
Os tipos selecionados para o teste são muito distintos entre si, variando em serifados, sem serifa, tipos bold, regular e light, condensados e expandidos, tipos romanos, itálicos e estilo manuscritos. Para classificar as amostras, parâmetros descritivos foram atribuídos a cada tipografia. Usando como exemplo a mesma Bodoni dos testes de Poffenberger e Franken, o tipo foi considerado (OVINK, 1938:149. TABELA XVI), em primeiro lugar, (1) luxuoso, seguido por (2) preciso, (3) digno, (4) confortável, (5) higiênico, (6) econômico (7) forte e (8) confiável. Foi relacionado a temas (1) satíricos e poemas, (3) tragédia, (4) aventura, (5) relatórios práticos, (6) análises objetivas e estilo de vida fazendeiro e (8) técnicos (OVINK, 1938:146. TABELA XII).

Os resultados foram tratados em 14 tabelas e quadros descritivos. Entretanto, Ovink aponta a impossibilidade de extrair mais detalhes das informações obtidas. Reconhece e conclui preliminarmente que, para o público comum, os valores atmosféricos da tipografia não são tão distintos e constata que o layout da composição pode influenciar a percepção das qualidades de um tipo, tornando-o inadequado para situações não muito apropriadas. Por outro lado, os resultados demonstraram que qualidades específicas foram atribuídas como adequadas para ao menos uma tipografia e que a dimensão do peso das letras (light e bold) é responsável por significados emocionais dos tipos. Ovink finaliza aconselhando:

“Portanto, o tipógrafo, que não acertou no tipo especialmente adequado, não terá causado um prejuízo efetivo na transmissão do significado do texto, mas ele terá perdido a oportunidade de intensificar a força da impressão do texto em um grau considerável" (OVINK, 1938:177 - grifo meu, tradução minha $a^{19}$ ).

Em 1968, Albert J. Kastl e Irwin L. Child (1968), ampliaram os estudos anteriores reunindo nos testes as variações de estilos bold e light, tipos com formas mais angulares e mais arredondadas, estruturas mais 30 simples e outras mais adornadas, tipos serifados e sem serifa, que foram relacionados a oito grupos de sensações ou "humores" (moods). Informações importantes como contraste, presença de eixo e tipo de serifa, não foram incorporadas nos resultados. A conclusão dos testes demonstram,

19 "The typographer therefore, who did not hit upon the specially appropriate type, will not have done actual harm to the transmition of he meaning of the text, but he missed an opportunity to intensify the force of impression of the text in a considerable degree." (ovink, 1938:177).

o1 por exemplo, que tipos bold simples e sem ornamentos, estão relacionados a algo fúnebre, melancólico, pesado e trágico, enquanto tipos light, simples e mais curvilíneos são alegres, vivazes, sonhadores, graciosos e poéticos (FIGURA 031).

05 Um pouco mais recentes, as pesquisas de Veronica M. Hofman, de 1988 e Eva R. Brumberger, em 2003, abordaram os mesmos questionamentos: as conotações e os valores emocionais associados à tipografia, incluindo métodossemelhantes para aferição dos valores. Hofman avança na análise da eficiência de tipografias, associadas em estudos anteriores a certos

sentimentos e conotações, quando aplicadas a conteúdos relacionados a tais significados, reforçando essas mensagens para o leitor. Os conceitos para os testes foram apresentados aos participantes pelo método de diferencial semântico, em que pares bipolares de adjetivos ou antônimos representam significados opostos (HOFMAN, 1988:10) (FIGURA 032).

15 Cada par de conceitos recebe um valor na escala de 1 a 7 , indicando a intensidade de cada um. Por exemplo, o par quente/frio é composto por: (1) extremamente quente; (2) quente; (3) mais quente do que frio (4) neutro (5) mais frio do que quente; (6) frio (7) extremante frio.

Table 1

List of Antonym Attributes hard/soft

light/heavy

serious/humorous

expensive/cheap

pleasing/annoying

modern/old-fashione

energetic/relaxed interesting/boring

masculine/feminine

liberal/conservative

rugged/delicate

prominent/ordinary

trendy/traditional impulsive/restrained

active/passive

violent/peaceful

sentimental/unmoving

informative/frivolous

youthful/mature

romantic/dispassionate

mysterious/straight-forward
TABLE 3

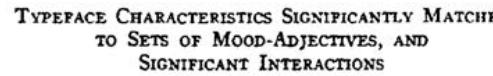

TyETrves, ANI
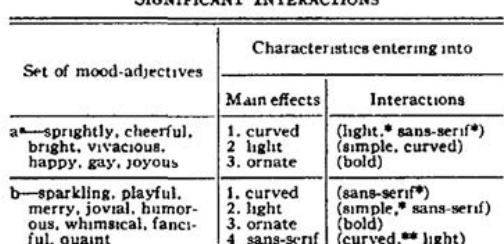

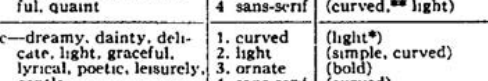

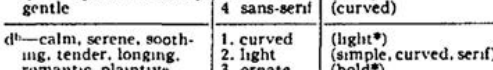



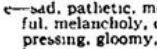



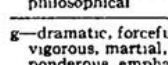

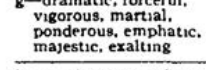

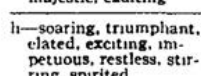

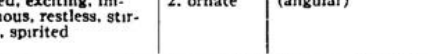

FIGURA 031_Tabela de conclusão dos testes de Kastl e Child com a relação entre as caracteristicas dos tipos em combinação com grupos de sensações, adjetivos e interações com variação de estilos.

FIGURA 032_Lista dos 22 pares de conceitos opostos usado nos testes de Veronica Hofman em 1988.
Um exemplo do resultado obtido foi a classificação da Garamond como "cara, tradicional, pacífica e madura" enquanto a Helvetica Bold fo considerada "rude, imóvel, direta/franca e imparcial" (Ibid.52). Entretanto, uma conclusão baseada no fato de a Garamond ser um tipo com design originado da escrita manual, com fortes características humanísticas 
não pode ser generalizada. Se compararmos duas versões da fonte (FIGURA 033), uma produzida pela type foundry Monotype $^{\oplus}$ e outra pela H. Berthold ${ }^{\oplus}$, é possível perceber uma sutil mudança em seu tom, nas

Garamond garamond

MONOTYPE

Garamond garamond BERTHOLD

FIGURA 033_Amostras da Garamond Monotype ${ }^{\circ}$, em cima, e da Garamond H. Berthold, em baixo, comparam as diferentes percep̧côes possiveis para as duas versões.

EIGURA 034_Escala de atributos da pesquisa de Eva R. Brumberger de 2003. Com valores de 1 a 7 para cada atributo. informações subjetivas que as formas transmitem e que influenciam a resposta emocional do leitor. Na primeira, as hastes nem sempre são paralelas, revelando a tensão no traçado caligráfico, e as formas curvas dos arcos, bojos e ganchos são mais fluídas e contínuas do que na segunda. Ainda, o contraste é bem maior e a itálica é mais inclinada e condensada. Conforme os parâmetros citados na lista de conceitos, a versão da Monotype parece ser mais liberal, ágil, rápida na escrita, assim como mais elegante e feminina. A versão da Berthold, tem uma postura mais estável entediada, madura, masculina. Evidentemente, essas observações passam pelo crivo do repertório pessoal de um designer e podem discordar da opinião de outro observador.

No estudo de Brumberger (2003:210), a escala de diferencial semântico, baseada em conceitos opostos, foi substituída por uma lista de atributos unidimensionais concentrada naqueles conotativos (FIGURA 034) excluindo os denotativos como "escura", "redonda", "angulosa", etc. Essa direção única dos conceitos, segundo a pesquisadora, evita distorções de compreensão e entendimento do que são, de fato, opostos. Uma oposição entre os conceitos "masculino" e "feminino" poderia ser interpretada de formas diferentes e influenciar o resultado.

\begin{tabular}{|lccccccc|}
\hline \multicolumn{10}{|c|}{ Not at all } & \multicolumn{9}{c|}{ Somewhat } & & Very \\
Cheap & 1 & 2 & 3 & 4 & 5 & 6 & 7 \\
Cold & 1 & 2 & 3 & 4 & 5 & 6 & 7 \\
Confident & 1 & 2 & 3 & 4 & 5 & 6 & 7 \\
Dignified & 1 & 2 & 3 & 4 & 5 & 6 & 7 \\
Elegant & 1 & 2 & 3 & 4 & 5 & 6 & 7 \\
Feminine & 1 & 2 & 3 & 4 & 5 & 6 & 7 \\
Formal & 1 & 2 & 3 & 4 & 5 & 6 & 7 \\
Friendly & 1 & 2 & 3 & 4 & 5 & 6 & 7 \\
Invitity & 1 & 2 & 3 & 4 & 5 & 6 & 7 \\
Loud & 1 & 2 & 3 & 4 & 5 & 6 & 7 \\
Masculine & 1 & 2 & 3 & 4 & 5 & 6 & 7 \\
Playful & 1 & 2 & 3 & 4 & 5 & 6 & 7 \\
Pretentious & 1 & 2 & 3 & 4 & 5 & 6 & 7 \\
Professional & 1 & 2 & 3 & 4 & 5 & 6 & 7 \\
Relaxed & 1 & 2 & 3 & 4 & 5 & 6 & 7 \\
Scholarly & 1 & 2 & 3 & 4 & 5 & 6 & 7 \\
Serious & 1 & 2 & 3 & 4 & 5 & 6 & 7 \\
Sloopy & 1 & 2 & 3 & 4 & 5 & 6 & 7 \\
Straightforward & 1 & 2 & 3 & 4 & 5 & 6 & 7 \\
Warm & 1 & 2 & 3 & 4 & 5 & 6 & 7 \\
\hline
\end{tabular}

D objetivo do estudo de Brumberger foi estabelecer uma personalidade para cada uma das 15 tipografias avaliadas, no contexto da palavra e em passagens de texto. Os dados obtidos nas entrevistas foram entabulados em softwares matemáticos para determinar coeficientes e

analisar variantes e correlações entre as tipografias. Apesar de identificar personalidades para os tipos avaliados, a pesquisa também revelou que a adequação dessas personalidades é determinada pela linguagem do texto, estilo da escrita, tema em que o texto está centrado e a audiência e propósito aos quais o texto é direcionado, ampliando muito as variantes para que se alcancem conclusões absolutas.

Em 2006, Chaparro, Fox e Shaikh (2006, s.n.) conduziram estudo baseado em testes com cerca de 1000 participantes, expostos a 20 tipografias (FIGURA 035), que analisaram as fontes sobres suas personalidades e a situação de uso mais apropriada (websites, documentos comerciais,

assuntos infantis e mensagens informais de cumprimentos). As fontes foram apresentadas aos participantes em quadros simples, com o alfabeto e sinais de pontuação sem diagramação específica. Para os testes de personalidade foi usado o método de diferencial semântico com 15 pares de adjetivos opostos, em uma escala de quatro pontos. Os resulta-

20 dos gerais compilados reuniram grupos de fontes que compartilham os mesmos traços de personalidades:

Fontes sem serifa: não se destacaram como um grupo, sendo classificadas como fontes para uso geral:

Fontes serifadas: uso em temas mais tradicionais: estável, prática, madura e formal;

Fontes manuscritas ou fantasia: uso em temas criativos e alegres; ovem, feliz, criativa, rebelde, feminina, descontraída, e amigável;

Fontes display "modernas": para temas assertivos e ousados:

masculina, assertiva, rude, triste e grosseira;

Fontes monoespaçadas: temas simples; desinteressante,

sem graça, sem imaginação e previsível.

Outra compilação listou os 30 adjetivos e as três fontes que mais foram relacionadas a cada um. As conclusões desse teste não surpreendem. Fontes sem serifa por exemplo, são preferidas em ambientes digitais, como website e revistas online, e não são apontadas para temas infantis, que
Cambria Constantia Corbel

Candara Calibri Consolas Times New Roman Arial

Verdana

Comic Sans

Century Gothic Courier New

Impact

gigi

Kristen

Rage Pratic

Georgia

Monotype Corsiva

FIGURA 035_As 20 tipografias usadas nos testes de Chaparro Fox e Shaikh, em 2006, realizados online. A maioria é de fontes nativas de sistemas operacionais ou web safe fonts. 




mostram preferência por tipos fantasia, decorados ou manuscritos. A serifada Times New Roman foi mais indicada para textos em websites e para documentos administrativos comerciais, vinculada aos atributos de estabilidade, previsibilidade, educação, maturidade, formalidade e praticidade. As fontes mais bold e condensadas receberam pontuação nos atributos de rigidez, aspereza tristeza, pouco atraente, masculina e grosseira (CHAPARRO, FOX e SHAIKH, 2006, S.n.) (FIGURA 036).

As associações revelam, aparentemente, dois lados: uma impressão é que os participantes relacionaram as fontes de acordo com as situações em que fontes similares são usadas no dia a dia e lhes são familiares nessas ocorrências, como a Times New Roman, chegando a conclusões previsíveis outra atitude, observada nas avaliações distintas para fontes com propostas formais mais próximas, como Cambria e Constantia, foram associações conotativas e metafóricas com base no aspecto das formas das letras.

Nas pesquisas e testes estudados, as tipografias foram selecionadas de modo diversificado, mesclando tipos para textos com tipos para títulos, provavelmente para que os participantes

FGURA 036_As 20 fontes dit categorias de adjetivo

afgrstGQR dos testes pudessem identificar claramente as diferenças entre elas e direcionassem seu julgamento para aspectos mais abrangentes de cada tipo. Porém, sutilezas de desenho dos traços em letras muito semelhanafgrstGOR tes, como Helvetica, Univers e Arial (FIGURA 037), por exemplo, não foram afgrstGQR nerbal dos participantes. De acordo com Rehe (2007: 57), os leitores hormais não con listintas e verbalizá-las. Porém, são capazes de rut


(alto), Univers (meio) e Arial (em

baixo). Todas as fortes se enquadram um sentimento indefinido de que há algo de "errado" ou "diferente" no
design, como perceber a mudança na tipografia de seu jornal habitual que antes era composta em Baskerville e agora está em Goudy.
2.4 A FACE DOS TIPOS E SUAS CONOTAÇÕES_ As duas propriedades mais fundamentais de uma tipografia são a funcionalidade e a expressão, ou as conotações que suas formas sugerem. De acordo com Moen (2000), quando um texto é lido, o primeiro contato é com a o5 composição tipográfica, o tipo de letra, seu tamanho, peso, cor, sua disposição no espaço da página, e compreende-se sua mensagem literal Em um segundo momento, baseado no próprio repertório cultural e emocional, o leitor percebe se o tipo está adequado ao design geral e se este reflete ou potencializa o conteúdo do texto - então compreendemos a mensagem conotativa (MOEN, 2000:125).

A funcionalidade reside em representar eficientemente o texto e seu significado. Questões de legibilidade, conforto visual para leitura (leiturabilidade), bom rendimento no espaço e flexibilidade de estilos para a composição, são qualidades que muitas tipografias têm, das mais clássicas

15 às mais contemporâneas, mas isso não garante a eficiência na condução da mensagem. Além da legibilidade óptica, a aparência da tipografia desencadeia sentimentos no leitor, podendo criar um impacto positivo ou negativo (HOCHULI, 2008:54). Esse é um segundo nível de atributos, mais subjetivo e menos mensurável. São valores expressivos intrínsecos 20 decorrentes da maneira como o tipo é utilizado e de seu aspecto como estilo, diferenciação e personalidade. Hochuli afirma: "Parece ser uma evidência pragmática que, além de sua função primária e essencial de atuar como um meio visual de transporte para a linguagem a tipografia também é capaz de comunicar uma atmosfera" (HOCHULI

2008:54 - grifo meu, tradução minha ${ }^{20}$ ). Para Lewis e Walker (1989:243) existem dois modos pelos quais a tipografia pode transmitir suas qualidades conotativas. Um, é associá-la consistentemente à um contexto em particular. Outro, mais duradouro e memorizável, é pela capacidade perceptiva gerada pela padronização visual de suas formas. Um tipo em bold, observado isoladamente, pode conotar espessura e volume, ou, dependendo do ambiente e do contexto em que o tipo estiver correlacionado, pode conotar, então, peso, densidade, gravidade (FIGURA 038).

O designer de tipos Gerry Leonidas (2012:50) considera esses valores expressivos da tipografia o ponto menos tangível da tipografia, que também

20 "This seems to be pragmatic evidence to show that, over and above their primary and essential task of acting as a visual means of transport for language, typefaces are also able to communicate a tmosphere (носниLl, 2008:54).
Navio de maratul

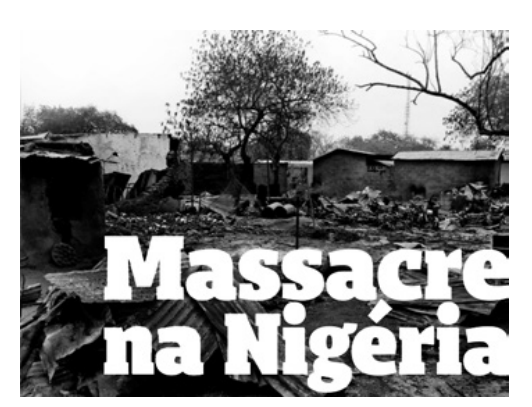

FIGURA 038_ A mesma tipografia apresentada em duas situaçōes distintas, proporcionam diferentes percepçōes. 
é um dos mais instigantes para os designers. Esses dois domínios são articulados para criar a relação entre produzir palavras como mensagem e a consequente transmissão dos valores de suas formas visíveis. No mesmo sentido, Stöckl (2005:205) afirma que não existe um discurso sem qualidades vocais e entonação, do mesmo modo que não há um texto impresso ou escrito "sem qualidades (tipo)gráficas", usando a metáfora do corpo e roupa para designar a funcionalidade e a expressão visual dos tipos. O tipógrafo alemão Erik Skpiekermann (2011:43) faz analogia semelhante ao dizer que, em muitos casos, as letras devem traduzir visualmente fatos lógicos e tabelas numéricas ou têm de "vestir" as palavras com aparências mais "agradáveis", mais "confortáveis" ou simplesmente mais "atraentes".

A pesquisadora e consultora em tipografia Beatrice Warde (1956), é mais conhecida por defender rigorosamente uma tipografia que não interfira na interface entre o leitor e a mensagem do texto, pregando a "transparência" ou "invisibilidade" dos tipos. O "olho mental" que absorve a informação deve focar através dos tipos, e não neles (WARDE, 1956:16). Para ela, um tipo ruim é aquele que, por causa de algum exagero desmedido no seu design ou um excesso de "cor", se interpõe no caminho da "imagem mental" que o texto deve transmitir. Contudo, quando discorre sobre as escolhas tipográficas, reconhece que os tipos têm outras qualidades 2 expressivas além da boa legibilidade:

O tipo, voz da página impressa, pode ser legível e desinteressante, ou legível e fascinante, de acordo com seu design e tratamento. [...] Componha uma página no tipo Fournier e a confronte com outra composta em Caslon e outra em Plantin, e será como se você estivesse ouvindo três pessoas diferentes proferindo o mesmo discurso cada uma com uma pronúncia impecável e clara, e cada uma o fará por meio de uma personalidade diferente (WARDE, 1956:137-138 tradução minha' $a^{21}$

Certamente, a ênfase de toda a sua argumentação é direcionada para a legibilidade dos tipos, mas, quando se remete ao "timbre da voz" de o1 um tipo, ela entra na questão do enorme potencial expressivo das sutilezas que o design da tipografia pode ter e, de alguma maneira, influenciar o "humor" e a percepção do leitor. A autora enfatiza essa questão ao afirmar que a melhor parte da sabedoria tipográfica reside no estudo de

05 suas conotações e a adequação de suas formas ao conteúdo (Ibid.:145), e fala do interesse pelas "roupas" que "vestem" as palavras, usando a metáfora que muitos tipógrafos atuais utilizam para justificar uma tipografia personalizada, assim como Stöckl e Spikermann, citados anteriormente e o designer Matthew Carter sobre a sua fonte Walker (capítulo 4, 4.5)

- Compreendendo o assunto sob um ponto de vista mais empírico, Warde afirma que termos tecnicamente indefensáveis usados para descrever tipografias, como "romântica", “fria”, "insensível", "alegre”, pertencem aos domínios da mente subconsciente (Ibid.) e, portanto, passiveis de ocorrer muitas interpretações.

15 O caráter conotativo das descrições a que Warde se refere são representações mentais formadas pela importação de signos daquilo que Barthes (1977:49) e van Leeuwen (2005:139) chamam de "domínios", para dentro de outros domínios em que nunca foram usados antes. Tais domínios podem ser um período histórico, uma cultura em particular ou

20 grupos específicos (profissão, grupo social, etc.). Van Leeuwen demonstra que o caráter conotativo da tipografia é um recurso importante para a formação de significados. $\mathrm{O}$ autor explica esse trânsito de signos entre os domínios que determinam conotações usando como exemplo a fonte Foundry Fabriek do designer holandês Wim Crouwel (FIGURA 039).

\section{ABC:DIEF=(j|HIJIKI_MN

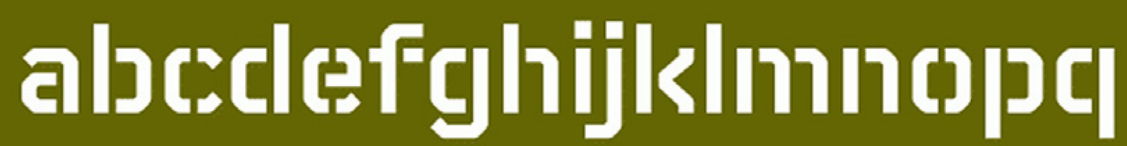 rstuvwxyz:1.2341567\%}

FIGURA 039_Tipografia Foundry Fabriek Bold, do designer de tipos holandês Wim Crouwel, de 2012, disponivel nos pesos light, regular médium, bolb e extra-bold. o tratamento descontínuo dado às hastes remetem aos processos de fabricação industrial em que partes são reunidas para formar um todo. A grade ortogonal usada para a construção das letras e o aspecto estêncil 
criado pela separação das hastes lembram também as inscrições rudimentares usadas para marcar embalagens e caixas de despacho da produção. O próprio designer sugere a aplicação da tipografia em blocos de concreto ou recortada a laser. Segundo van Leeuwen, é possível que as pessoas, ao verem um texto escrito com a fonte, façam o mesmo tipo de associação, pois a maioria delas já esteve em contato com formas similares nas mesmas condições relacionadas à indústria (VAN LEEUWEN, 2005 4:139).

Considerando o que foi exposto até aqui, pode-se afirmar que qualtem uma estrutura formal própria e com seus atributos individuais. Isso não quer dizer todas tenham uma personalidade forte ou destacada. Nos casos em que o tipo de letra tem características muito marcantes, com conotações claras como o exemplo citado, o caráter dos tipos é mais facilmente apreendido. Mas muitas letras se enquadram nas categorias "inexpressiva", "apática" ou "neutra" e aqui, neutralidade é um atributo ativo que exerce influência efetiva na percepção, ou seja, é um valor em si e não a ausência de algo. Existem tipos que não podem ser compreendidos apenas pelas bases da conotação, como as tipografias desenhadas para fins de leitura longa (livros, jornais etc.) ou outras que não ostentam a menor extravagância estética e que não indicam objetivamente uma origem determinada. Nesses casos, a metáfora é outra ferramenta semiótica que pode oferecer significado ou, mais especificamente, o "potencial metafórico de determinados aspectos das formas das letras" (Ibid.1140). A interpretação desses significados se torna ainda mais relativa, pois é resultado de sensações sujeitas a inúmeras variantes que influenciam tal julgamento, como o repertório cultural, predisposições, humor, preconceitos e outros. Em relação às formas tipográficas (FIGURA 040),

As fontes podem, por exemplo, ser angulosas, como no caso da Agency $F B$, ou arredondadas, como a Century Gothic, e ess 'arredondamento' imediatamente se presta como uma metáfora para 'organicidade', 'naturalidade', 'feminilidade' e outros conceitos correlacionados. As ascendentes podem ser mais longas do que as descendentes, como na Poor Richard, e isso pode, por exemplo, transmitir a ideia de 'almejar coisas maiores', E assim por diante (Van Leeuwen, 2005:140 — grifos do autor, tradução minha222). quer tipografia possui algum apelo emocional ou caráter subjetivo, pois

Esse exemplo envolve estruturas bastante distintas que facilitam, um pouco, as relações mencionadas pelo autor. Entretanto, essas associações metafóricas se tornam ainda mais sensíveis quando as formas das letras não possuem, aparentemente, muita distinção, como no exemplo anterior das Garamonds (FIGURA 033). Nesses casos, as interpretações emocionais se tornam ainda mais pessoais, sujeitas às idiossincrasias do indivíduo.

Isso leva à reflexão sobre o efeito real que as tipografias customizadas exercem na construção de uma identidade visual coesa e coerente. A similaridade entre as formas das letras, em tipografias atuais, pode ser tão exacerbada que o designer de tipos precisa atentar a muitos detalhes, em uma ou outra letra, para torná-la única e adequada ao discurso institucional. Se observadas por esse ponto de vista, as diferenças entre as fontes Fs Millbank (FontSmith), Petrobras Sans (Dalton Maag) e Parisin

(Typofonderie), as duas últimas estudadas em profundidade no capítulo 4, chegam a ser muitíssimo pequenas (FIGURA 041). As letras 'G' e 't' têm diferenças mais evidentes no tratamento do pescoço do 'G' e no cume do ' $t$ '. As proporções são parecidas, destacando a condensação maior da Petrobras Sans. A letra 'a' é um ponto de grande convergência do aspecto 20 do design, os remates dos ganchos e a maneira que o bojo se junta à haste é diferente nas três fontes. Esses pequenos detalhes podem interferir na percepção da fonte em seus

22 "Fonts can, for instance, be angular, in the case of Agency $\mathrm{FB}$ or rounded, as in readily lends itself as a metaphor for organicness' 'naturalness', femininity' and other related concepts. Ascenders can contextos, alterando o ritmo e a textura que um conjunto maior de letras produz, o que, pela perspectiva apresentada por van Leeuwen, proporciona relações metafóricas diferentes.

afgrstGQR

FIGURA 041_Comparação entre FIGURA 041_Comparação entre
caracteres-chave da FS Millbank (alto), Petrobras Sans (meio) $e$ Parisine (em baixo). Apesar das sutis diferenças, especialmente entre $a$ Millbank e Petrobras Sans,as fontes
possuem percepções diferentes em possuem percepções diferentes em
seus contextos.

\section{Agency FB Century Gothic Poor Richard}

FIGURA 040 No alto, a fonte Agency FB de David Berlow, 1995 um redesign do tipo criado por Morris Fuller Benton em 1933: ao centro, a Century Gothic de Benton, 1892; e embaixo, a Poor Richard de Paul Hickson baseada en um design de 1919. 


\section{TIPOGRAFIA CORPORATIVA PERSONALIZADA}

3.1 DEFINIÇÕES_ A prática do design tipográfico pode apontar para duas direções bastante claras: aquela praticada por razões individuais do designer, movido por desígnios criativos pessoais que podem ou não se tornar um produto comercial; e outra conduzida profissionalmente a

10 partir de uma solicitação formal com requisitos formais, conceituais e técnicos definidos.

A definição de uma tipografia customizada e seu intrínseco apelo de sustentação à identidade visual é comum a muitos designers e type foundries. Entre elas, a apresentada por Jonathan Hoefler (Hoefler \& Co.),

15 dirigindo-se ao seu potencial cliente, resume o discurso desse segmento e ressalta o potencial expressivo de tipografia customizada e seus benefícios econômicos:

Vemos palavras antes de lê-las. Uma tipografia define o tom daquilo que comunica e molda as expectativas dos leitores desde o primeiro olhar. É a parte de sua identidade com a qual as pessoas mais irão interagir e uma ferramenta que todos os seus designers usarão diariamente. A tipografia correta pode definir uma identidade, ajudando a lançar novas marcas e revigorar as já estabelecidas. Tipografias podem resolver problemas mensuráveis auxiliando na comunicação em novas mídias, funcionar em novas restriçōes, expressar novos tipos de informação e alcançar novos mercados. O tipo certo será a parte mais eficaz do seu programa de design e o investimento design mais acessível que você pode fazer (HOEFLER, 2014 - tradução minha ${ }^{23}$. 
A palavra customizar24, recentemente incluída nos dicionários, é o1 uma adaptação do inglês custom (cliente, usuário) e de to customize significando personalizar, ajustar ao interesse e gosto do usuário, construir adaptar ou alterar com o intuito de atender especificações individuais. Popularmente, a palavra está associada a adaptações e personalizações of executadas em produtos ou serviços, como a customização de roupas, por exemplo. Foi incorporada ao vocabulário técnico nacional para designar uma tipografia feita sob encomenda, ou seja, existe a figura de um contratante que solicita um projeto de design tipográfico para atender exigências próprias, sejam de ordem técnica, estética ou identitária. O termo se aplica tanto para tipografias criadas desde o início, a partir de desenhos ou esboços manuais ou digitais (from scratch), como também para alterações no design ou na estrutura do software da fonte. Outras expressões inglesas também usadas são bespoke (feita especialmente para uma pessoa em particular) e taylor made, como o alfaiate que corta uma roupa sob medida e a ajusta ao corpo do cliente, com todas as suas possíveis imperfeições. Portanto, muitas das tipografias já criadas se enquadram nessa definição, pois de alguma maneira foram concebidas para se ajustar ou atender uma determinada finalidade. Ainda assim podem ser de uso exclusivo de uma instituição ou não. Essencialmente, diferem-se das tipografias produzidas por uma demanda de expressão puramente pessoal ou, ainda, daquelas que perderam a condição de exclusividade e foram incorporadas aos catálogos de venda de varejo. Nesse contexto, existe atualmente uma enorme quantidade de opções disponíveis em catálogos comerciais das empresas fundidoras de tipos digitais, as type foundries ou font foundries, como FontShop ${ }^{\oplus}$, Linotype ${ }^{\circ}$ Monotype $^{\oplus}$, AgfaType ${ }^{\oplus}$, URW ${ }^{\oplus}$, Veer ${ }^{\oplus}$, entre tantas outras. Fabricantes de softwares com Microsoft ${ }^{\oplus}$ e Apple ${ }^{\oplus}$, por exemplo, encomendaram fontes para uso em seus sistemas operacionais conforme rígidas especificações técnicas relacionadas à legibilidade em telas e não são de exclusivas dessas empresas. Alguns designers de tipos não possuem muitas fontes para venda no varejo e dedicam-se prioritariamente a projetos customizados

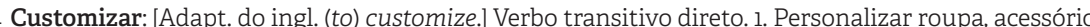
etc, para ajustá-los a o interesse ou ao gosto do usuário (Dicionário Aurélio): Customizar: verbo transitivo direto. Rubrica: informática. Regionalismo: Brasil, palavra a evitar, por personalizar (Dicionário Houaisss). Customize: verb [T] uk (UK usually customise) to make or change something according to the buyer's or user's needs (Cambridge Dictionar . o1 para clientes diretos que estimulam a criação de soluções singulares. Outra modalidade muito comum ao longo da história recente são as revitalizações de tipos clássicos (revivals), como ocorreu com a Garamond, para citar um caso, que oferece versões para diversas type foundries e

05 versões personalizadas para uso corporativo, como a Apple Garamond (1990), desenhada pelo designer de tipos Tony Stan para a ITC ${ }^{\odot}$ (International Typographic Corporation), uma fonte $80 \%$ mais condensada e mais leve que outras variações da fonte disponíveis comercialmente.

A demanda por fontes customizadas se justifica pela capacidade en

r. se alinharem totalmente com a linguagem gráfica da marca e da comunicação da instituição, sobretudo pela imensa oferta atual de fontes de níveis de qualidade variáveis. O amplo acesso aos meios digitais de desenho e geração de tipografias digitais resultou na democratização da produção de fontes sem precedentes na história. Há algumas décadas,

15 um projeto tipográfico envolvia uma grande equipe de profissionais e sua execução exigia tempo considerável, elevando os custos, os riscos e as responsabilidades que o produto final impunha. Com a produção centrada em um único indivíduo e com baixo grau de investimento tecnológico pelo designer, considerável parcela dessa produção é gerada

20 sem muito rigor crítico, apuro técnico ou propositivo em originalidade. Como observa o designer de tipos holandês Erik van Blokland em artigo escrito por Peter Bil'ak (2011) que indaga sobre a conveniência de tanta produção: “se uma tipografia que já existe pode fazer o trabalho, não há razão alguma para fazer uma nova”. Por outro lado, a avidez por novos

designs é sustentada pela demanda inconsciente do leitor por novidade mesmo que isso contrarie às vezes, o sentimento de conforto e hábito que tipos mais familiares exercem sobre eles. Como observa o designer de tipos e professor holandês Gerard Unger: Uma das razoes para a demanda por novas fontes é que as mais antigas e confiáveis são vistas com tanta frequência e são tão

familiares que perderam qualquer grau de novidade que um dia já tiveram, por conta disso, elas não conseguem mais nos surpreender (UNGER, 2007:116 - tradução minha'25). 25 "One of the reasons for the demand for new fonts is that the old faithfuls have been seen so offen and (I) can no longer surprise" (UNGER 2007:116). 


\subsection{OS PRIMEIROS TIPOS CRIADOS PARA PROPÓSITOS}

ESPECÍFICOS_A produção de tipografias para uso exclusivo de instituiç̃os corporativas é um conceito relativamente recente, mas a encomenda de tipos móveis para impressão para satisfazer demandas particulares remontam ao século xvil com o trabalho de cunho científico, desenvolvido por Jacques Jaugeon de 1693 à 1702 para o Commité Bignon da Académie des Sciences, o tipo Romain du Roi (ver capítulo 1). Mesmo assumindo que esse tipo foi construído sob a ótica filosófica racionalista do Iluminismo, algumas dimensões de seu processo e propósito caracterizam uma personalização e um uso reservado daquela tipografia. A partir desse período, outros tipos foram produzidos para executar tarefas específicas para livros, jornais e cartazes, sendo esse último demandante de uma grande produção de tipos carregados de expressividade e impacto visual ou "o exagero lúdico de uma série de atributos formais" (DIXON, 2012:G51) e responsável pela expansão de tipos para uso em tamanhos grandes (display, ornamentais e decorativos). As restrições impostas pelo formato e distribuição dos textos justificados em colunas estreitas, com espaços de entrelinhas apertados eram, e ainda são, desafios complexos para os designers de tipos em manter eficiência e economia em termos de legibilidade e conforto sem sacrificar a consistência visual 2 da página. Na área editorial, tipografias dedicadas a jornais e diários já eram produzidas no século XviII, quando o tipógrafo holandês Johann Michael Fleischmann (1701-1768), contemporâneo de Pierre Simon Fournier e John Baskerville e um virtuoso entalhador de tipos (punchcutter) extremamente pequenos, produziu a sua Galjart Courant-Letter para a Enschedé de Haarlem, Holanda. Em 1745, Fleischmann elaborou um tipo de oito pontos de tamanho para uso na impressão de jornais, "um dos primeiros para aquele propósito", segundo observou o designer de tipos inglês Matthew Carter quando realizou a sua fonte Fenway (1956) inspirada nesse modelo (MIDDENDORP, 2004, p.28)

Em 1894, outro tipo foi criado para atender um único projeto editorial, a Century Roman para revista de mesmo nome, a Century Magazine. O tipógrafo norte-americano Linn Boyd Benton, também inventor do dispositivo pantográfico para corte de matrizes tipográficas, trabalhou em colaboração com o editor Theodore L. De Vinne na concepção daquilo que "provavelmente é o primeiro tipo desenhado para um propósito específico" (LAWSON, 1990, p.281), respondendo às exigências de legibili- dade e questões técnicas de impressão vigentes. Não satisfeito com as opções disponíveis, derivações da Caslon que deixavam a página com um aspecto acinzentado, propuseram uma altura-de-x mais alta, engrossaram as hastes mais finas presentes nos tipos romanos modernos

reforçaram as serifas, para se livrar daquilo que consideravam o ponto crítico das tipografias da época. Cientes dos benefícios da economia de espaço em publicações extensas, as proporções da Century Roman (FIGURA 042) foram ajustadas para serem condensadas, resultando em uma página mais "negra", densa na carga de preto. Uma versão mais

estendida, a Century Broad-Face foi desenvolvida para casos em que a economia de espaço não era necessária (DE VINNE, 1914:376-377). Em 1917 o trabalho foi ampliado em pesos e itálicos pelo seu filho, Morris Fuller Benton, incluindo a nova Century Schoolbook, uma opção para materiais educativos e de alfabetização (LOXLEY, 2004:71-73). Na mesma propo-

sição, o também norte-americano Stanley Morison desenhou a onipresente Times New Roman (1932), a nova tipografia para o jornal britânico The Times, substituindo um tipo romano moderno do século XIX, com proposta de atualizar o design e também adaptá-la aos requisitos mecânicos da indústria de impressão.

20 Para a type foundry norte-americana Monotype a sua primeira tipografia customizada foi o tipo Veronese, em 1911, uma solicitação da editora J. M. Dent \& Sons Ltd., utilizada em uma edição limitada de poemas de Lorenzo de Medici, impressa pela

Ballantyne Press em 1912. Veronese é um tipo serifado, no estilo veneziano, inspirado em uma releitura William Morris dos tipos romanos old style de Nicolas Jenson do século XV (FIGURA 043).

Ainda no século Xx, a tipografia moderna pensada estritamente para

jornais surge com o Grupo da Legibilidade ${ }^{26}$, uma série de tipos clássicos redesenhados pela fundidora norte-americana Mergenthaler Lynotype Company entre os anos 1920 e 1930 para se adequarem às tecnologias de impressão vigentes, com foco principal na legibilidade e no bom desempenho com papéis, tintas e maquinários de impressão diversos (FRANCHI, 2013:116).

26 Legibility Group, série de tipografias produzidas pela Mergenthaler Linotype, otimizados para máxima leitura, especialmente para jornais. Era composto pelos tipos: Ionic No 5 (1925), Excelsior (1931), Opticon (1936), Paragon (1936) and Corona (1941).
THE CENTURY MAGAZINE

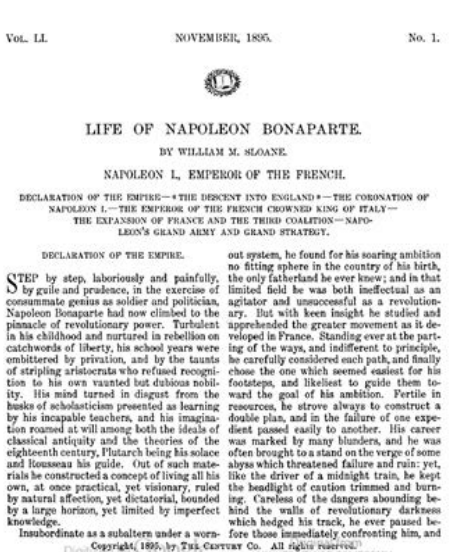

FIGURA 042_Página The Century Magazine, usando pela primeira vez a tipografia Century Roman, design de Theodore L. De Vinne e Linn Boyd Benton, 1895

\section{THE BOOK PAG} AUTHOR OF "THE CATALOGUE," "THE

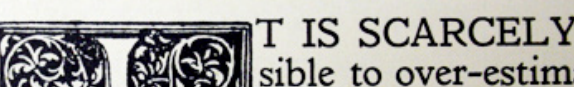
sible to over-estim importance of the a
ance, or presentm
the printed page

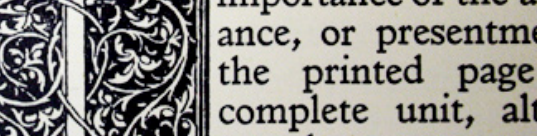
2) even by many expe

FIGURA 043_Monotype Veronese composta em corpo 12 Monotype Recorder, 1914. 
Desde a Century e a Times New Roman, muitos tipos foram projetados exclusivamente para jornais, um setor exigente que demanda um produção constante de tipografias próprias. Por se tratar de um produto essencialmente formado por textos e cuja elaboração tem crescido na qualidade do design e na complexidade de recursos técnicos, os tipos necessitam acompanhar e responder às imposições dessa conjuntura. Legibilidade, espaços e entrelinhamentos, hierarquia intrincada de informações, profusão de cores, fotografias e infográficos, adaptação aos softwares de produção e a velocidade de impressão, por exemplo, desafiam continuamente o máximo desempenho de uma fonte. Muitas das fontes criadas em função de seu uso em editoriais extensos, atualmente, não são de uso exclusivo e podem estar disponíveis para venda em catálogos de type foundries como a Miller (Matthew Carter, 1997), a família Thesis (Lucas de Groot, 1994-1996). Almeria, Coranto (Gerard Unger 2000) Gulliver (idem, 1993), para citar apenas alguns exemplos. Outras, como a Le Monde (Francoise Porchez, 1994) e a Guardian (C. Schwartz e P. Barnes, 2004-2005) foram empregadas com exclusividade por anos e depois disponibilizadas para venda. Já o jornal brasileiro Folha de S. Paulo e revista de notícias alemã Der Spiegel, por exemplo, mantêm suas fontes proprietárias Folha Serif ${ }^{27}, 1994$ (FIGURA 044) e Spiegel, de 1996, desde suas implantações na identidade das publicações, ambas desenvolvidas pelo designer de tipos holandês Lucas de Groot (Lucas Fonts/Font Fabric).

\section{Graça só foi alertada por ex-gerente sobre desvios este ano, diz Petrobras}

\section{Comunicado da estatal sai quatro dias após vir a público a informação de que uma}

- Planalto faz sondagens para substituir Graça Foster $\quad$ " Denunciante for punida por economizar RS 34,2 mi

Quando uma marcajá nasce com status de ícone, a tipografia é uma aliada vital para suportar essa força visual. Quando o designer gráfico norte-americano Lou Dorfsman assumiu, em 1954, a direção criativa de marketinge promoçãodarededetelevisão CBS ${ }^{28}$ (Columbia Broadcasting

27 Folha serif: tipografia desenvolvida por Lucas de Groot em parceria de Erik Spiekermann, para o projeto de redesign do jornal Folha de S. Paulo em 1994

28 CBS: o "olho pictografico", marca criada por William Golden para a CBS Television, em 1951, simboliza
System) recebeu a tarefa de dar continuidade ao trabalho de seu antecessor, o também designer William Golden, criador do famoso símbolo do "olho", em 1951 (FIGURA 045), juntamente com o artista gráfico Kurt Weiss (HELLER, 2008). Para dar apoio ampliar a repercussão visual que a marca icônica alcançou, em 1962 Dorfsman dirigiu o redesenho do

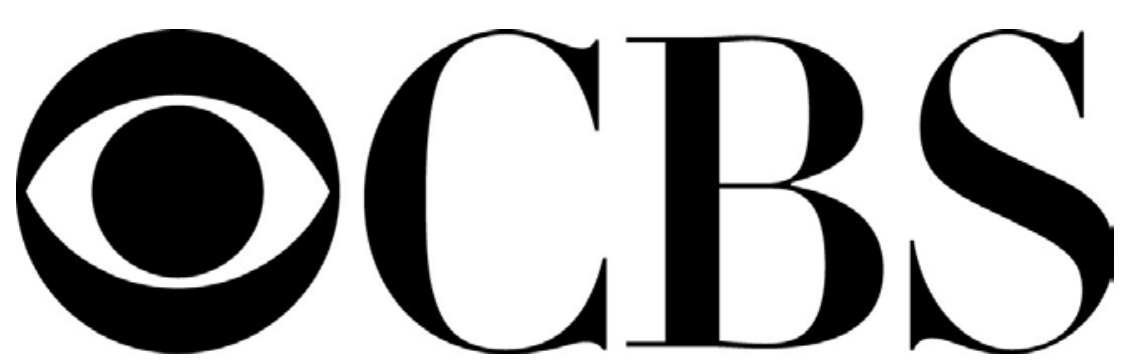
tipo Didot que já era usado em algumas instâncias da comunicação da emissora, com a ajuda do designer de tipos Freeman Craw, a que chamou de CBS Didot: uma versão apenas em maiúsculas, levemente mais condensada que a normal, cujos contrastes são levados ao extremo e caracteres ganham desenhos próprios como a cauda do ' $Q$ ', a espinha e barra mais sinuosa do ' 2 ' e uma transição do contrast das curvas mais abrupta, deixando a parte interna do 'O', por exemplo, menos arqueada (FIGURA 046). Apesar do contraste extremo entre hastes grossas e finas e da aparência clássica das letras, o que dificultava - seu uso em tamanhos muito pequenos, tornou-se a tipografia oficial da emissora por mais de uma década e era empregada em todo o material gráfico corporativo, desde a papelaria, sinalização interna e externa, dos elevadores até os guardanapos, inclusive os números dos relógios instalados nos escritórios (FIGURA 047). Empregada sistematicamente em ambientes, suportes e objetos muito diversos, adquiri propriedades de identificar a marca CBS de forma mais sutil, espalhad nas mensagens textuais, acompanhando e preservando a força do símbolo. Em 1970, os designers Tom Carnase e Herb Lubalin desenharam uma versão atualizada da CBS Didot para fotocomposição chamada de

ITC Didi, à qual foram adicionadas as minúsculas e demais caracteres, e digitalizada em 2013 pelo designer Jason Walcott para a type foundry CounterPoint sob o nome Domani (FONTS.COM, 2014).

No Brasil dos anos 1980, o designer uruguaio Eduardo Bacigalupo então diretor de criação da SAO - uma divisão dedicada ao design gráfico da agência de publicidade DPZ, desenvolveu dois projetos tipográficos de uso exclusivo. $O$ primeiro foi para a empresa paulista de aviação VASP, uma tipografia criada a partir do logotipo da empresa, uma
FIGURA 045_Marca de William Golden para a CBS Television. O olho das imagens de vídeo

abedefghijkl mnop(qrstur WXYZABCD EFGII.JKL MVOPQRS TUVWXYZ d.!'?\$12345 67890

FIGURA 046_CBS Didot, desenhada por Freeman Craw em 1966 é uma tipogarfia baseada nas tês letras do logotipo criado por W. Golden.



FIGURA 047_ A tipografia CBD Didot empregada desde mostradores de téa sinalização externa. pictográfico que simboliza o poder 
prática já comum em projetos de identidade corporativa dos Estados Unidos e da Europa (MELLO e COIMBRA, 2011:527). A tipografia (FIGURA 048a), digitalizada pela designer Fernanda Martins, mantém todas as características do logotipo como a ausência da barra na letra 'A' e a ligação das letras 'AS', incluindo várias ligaturas com uma possível influência do tipo Avant Garde do americano Herbert Lubalin. Com o mesmo intuito, a tipografia para a multinacional Bardahl foi amplamente utilizada na linha de embalagens dos produtos automotivos (FIGURA 048b).

FIGURA 048 a_A esquerda, a tipografia criada para a VASP, em 1986, pelo designer Eduardo Bacigalupo.

FIGURA 048 b_A direita, $a$ tipografia para a Bardhal, em 1988

PAPMALIOID A: $D$ D $=$ सि CNOPOTH


(12345:78:0)
3.3 EXCLUSIVIDADE OU PRATICIDADE No momento de defini uma tipografia corporativa, há basicamente dois procedimentos a considerar: a escolha por uma fonte digital disponibilizada comercial- 20 mente em catálogos; e por aquelas projetadas exclusivamente para atender as condições particulares de cada caso. As fontes de catálogo não podem ser simplesmente compradas como um bem qualquer, mas n verdade adquire-se uma permissão para sua utilização, as licenças de uso, por tempo indeterminado. Estando disponíveis para qualquer usuário, dependem fortemente de outros fatores para se integrar a um sIV com os mesmos vigor e importância das cores corporativas e da própria marca. Uma solução possível é solicitar ao designer ou distribuidora uma versão personalizada de uma fonte de seu catálogo. Uma tipografia muito popular como a Helvetica, por exemplo, pode ganhar uma nova versão, com condensação ou inclinação singulares e até a inclusão de caracteres especiais (inexistentes na fonte original). Essa versão passa, então, a ser de uso exclusivo do contratante, não podendo ser comercializada para o público. Isso atende parcialmente o propósito de distinção da tipografia institucional.

Em razão de seu design único e original, as fontes personalizadas ou customizadas (termo usado doravante) têm um potencial maior para construírem uma identidade integrada com toda a comunicação, pois são empregadas exclusivamente por aquela instituição e ganham potencial de reconhecimento mesmo quando a marca ou outro elemento da identidade não estão presentes. Além dessa premissa, outras perspecti-

o5 vas dão sentido a essa prática e não devem ser ignoradas:

Quando uma identidade corporativa é desenvolvida, as decisōes tipográficas sempre ficam subordinadas a outras decisões que acontecem em diversos níveis. Pelo fato de estar incorporada a um todo maior e ser um elemento constituinte da imagem da organização, a tipografia necessita de um cuidado muito maior As fontes são tecnicamente flexíveis e preparadas para uso internacional? Os custos de licenciamento para todos os computadores da organização foram levados em conta? Quando o cliente é muito grande, o escritório de design pode propor a elaboração de uma família de fontes customizadas para reduzir custos de licenciamento (MIDDENDORP, 2012:32 - tradução minha29).

Um fator que reforça a função de um único tom de voz tipográfico 20 é a expansão tecnológica dos meios de comunicação. Até meados da década de 2000, a tipografia era projetada primariamente para os meios impressos e aplicações em meios digitais eram secundárias. Atualmente, a prioridade tem, de forma gradativa, tomado outra direção, com designs tipográficos priorizados para os meios digitais, telas de dispo-

sitivos eletrônicos e tipos em movimento. As questões de projeto têm se voltado para que tipo de tela a fonte deverá ser usada, um laptop doméstico, uma TV normal ou Full HD, um celular comum ou um dispositivo com resolução de tela de última geração. Portanto um alinhamento do design e da constituição técnica de uma fonte corporativa com 3o os diversos meios em que deverá funcionar tem sido condição decisiva para uma eficiente manutenção da identidade visual e reconhecimento da marca.

"When developing aco that take place on many different levels Precisely hecause the typography will be embedded in alore whole and will be constituent of the organization's image, it needs extra care Are the fonts technically flexible and equipped for international use? Has the cost of a group license for all the organization's computers been taken into account? When the client is huge, the design agency may propose to have a custom font Family designed to save costs on licensing" (MIIDENDDRP, 2012:32). 
Outro aspecto que influi na escolha por uma ou outra opção na composição de um siv é a questão econômica e legal. Enquanto uma tipografia desenvolvida exclusivamente para a instituição tem um custo variàvel, que depende da experiência e prestígio do designer ou da type foundry, da complexidade do projeto e da quantidade de estilos e requisitos técnicos. as fontes de catálogos comerciais precisam ser adquiridas em quantidades de licenças às vezes muito altas para suprir a demanda de toda a estrutura da organização, o que impacta diretamente os custos de implementação da fonte. Se a organização ampliar seu porte ou planejar uma expansão geográfica, mais licenças devem ser adquiridas e no caso de a fonte se requisitada também em websites, algo desejável porque reforça a tipografia como identidade, mais licenças ou fontes projetadas unicamente para esse ambiente devem ser providenciadas, elevando ainda mais os custos. A cessão dos direitos autorais (copyright) pode ser totalmente transferida ao cliente ou feita parcialmente, por um período determinado em contrato, após o qual os direitos da fonte retornam ao designer, como no caso da fonte Walker de Matthew Carter (capítulo 4, 4.6), ou passa a incorporar o catálogo comercial para vendas ao varejo, como aconteceu com as famílias Parisine (capítulo 4, 4.2) e Guardian (capítulo 4, 4.3). Algumas type foundries disponibilizam licenças em número ilimitado de usuários e dispositivos em que a fonte pode ser instalada (Corporate Licences ou Multiple-User Licence), mas o custo, mais alto, é calculado para cada estilo da fonte e pode inviabilizar o investimento.

Uma opção mais viável economicamente é customizar uma tipogra-

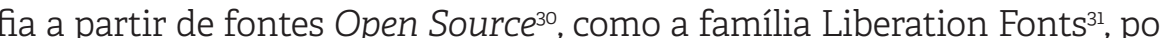
exemplo. A Universidade de Brasília reformulou sua identidade visual em 2008. A estratégia escolhida para cumprir todas as exigências de estrutura da universidade e do orçamento disponível foi utilizar uma fonte de uso livre. O designer brasileiro Gustavo Ferreira tomou como ponto de partid a fonte livre Liberation Sans por sua qualidade técnica e similaridade com as famílias tipográficas usadas anteriormente. Além disso, os parâmetros métricos de espaçamento desta fonte são os mesmos de fontes de sistemas

Open Source fonts fo modificadas, distribúdas. A liberdade de uso é assegurada por licenças de uso livre como a GP

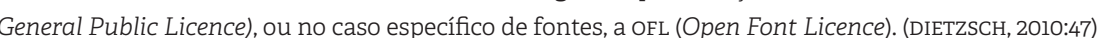
31 Liberation Fonts: uma familia de fontes livres Open Source True Type (TTF) composta dos estilos Liberation Sans, Liberation Serif e Liberation Mono (monoespaçada).

\section{Liberation Sans BbCcJjQqTt158\& BbCcJjQqTt158\&}

Arial

operacionais como Arial (FIGURA 049), Times New Roman e Courier New, o que a torna extremamente compatível com softwares do pacote MS Office muito utilizado pelos departamentos administrativos. A tipografia customizada para a UnB (FIGURA 050) têm a versão UnB Pro, com modificações significativas em alguns caracteres e geração de uma gama maior de estilos de pesos; e a UnB Office, praticamente idêntica à Liberation Sans com a adição de alguns caracteres especiais (DIETZSCH, 2010:48).

Soma-se a isso o fato de essas fontes estarem disponíveis a qualquer usuário que pode obtê-las em catálogos comerciais, o que é intensificado quando a escolha recai nas fontes padronizadas de sistemas operacionais (system fonts ou web safe fonts), que, nesse caso, não têm um custo direto. Muitas das fontes incorporadas em sistemas operacionais são designs optimizados para um melhor desempenho em telas de computador em detrimento de seu aspecto quando são impressas, o que não é apropriado para usos mais diversificados. Contudo, uma fonte customizada de pro-

o priedade da instituição que a encomendou pode ser rapidamente ajustada e incrementada, o que não ocorre de modo tão fácil com fontes de catálogo. No caso do projeto de uma revista semanal de variedades ou de moda, por exemplo, a tipografia pode acompanhar as constantes mudanças editoriais e temáticas da publicação, alterando ou criando versões da mesma fonte usada como base. Caracteres não alfabéticos como ornamentos, pictogramas (dingbats), caracteres alternativos ou ligaturas, podem ser adicionados a custos acessíveis.
FIGURA 049_Comparação dos espaçamentos entre a fonte Liberation Sans a Arial da Monotype ${ }^{\circ}$

Universidade DE BRASÍLIA Universidade DE BRASÍLIA Universidade DE BRASÍLIA Universidade DE BRASÍLIA Universidade DE BRASÍLIA Universidade DE BRASÍLIA

FIGURA 050_A família de fontes UnB Pro, de 2008, customizada partir da Liberation Sans. 
A type foundry TypeTogether publicou um pequeno manual sobre o1 FIGURA 051_Tabela que mostra os letreiramentos, uso de fontes e tipografia customizadas em que apresenta quatro pontos a considerar no investimento de uma fonte corporativa: o propósito de uso, requerimentos técnicos, considerações estéticase orçamento/licenciamento.

um quadro comparativo (FIGURA 051) com a relação de custo entre fontes de revenda (catálogo) e fontes customizadas. Nele, serviços e produtos da empresa estão dispostos em relação ao investimento necessário e o os grau de intervenção ou originalidade da fonte (TYPETOGETHER, 2014, s.n.).

\section{RETAIL FONTS}

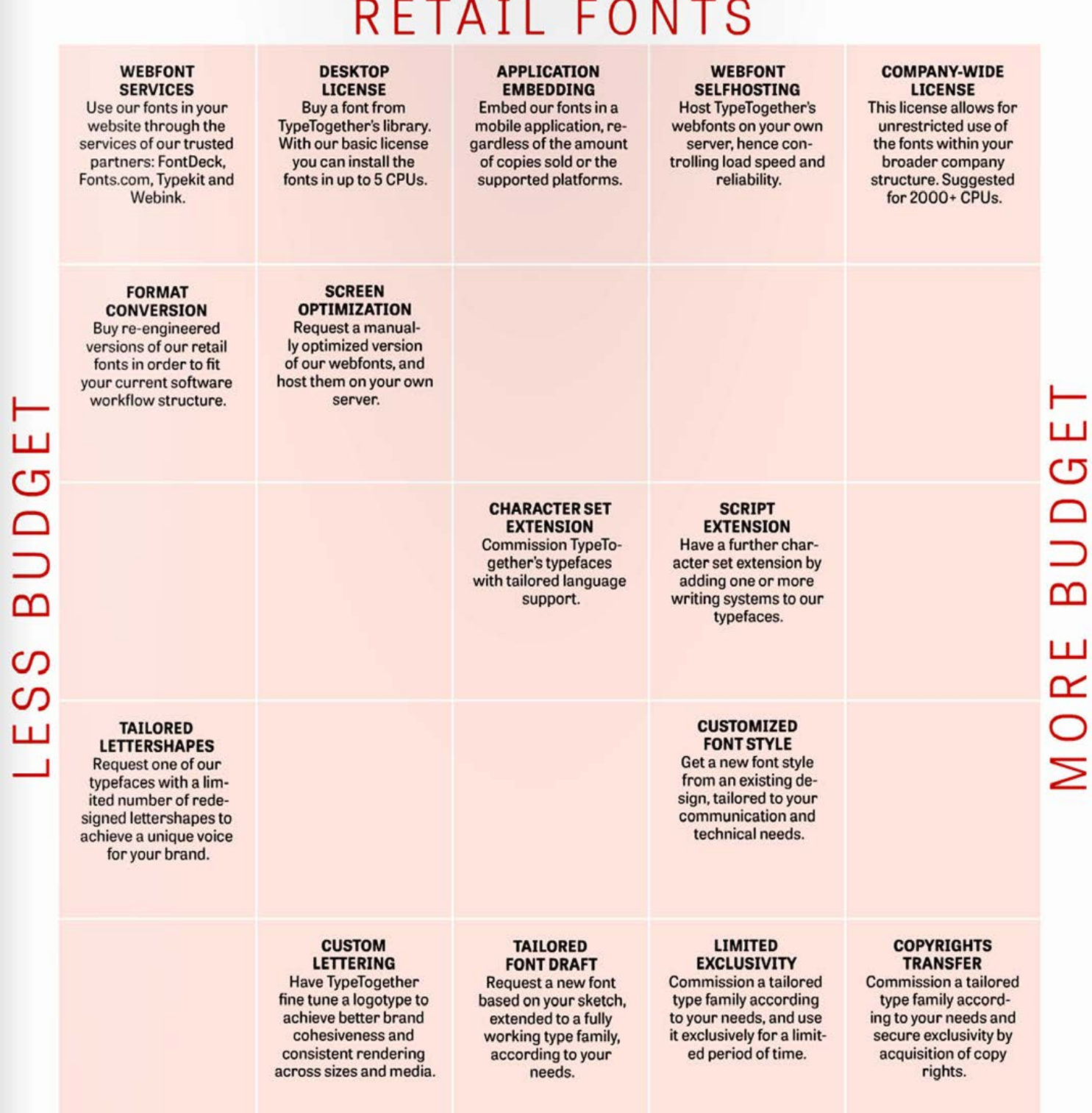

TAILORED FONTS

\section{o1 3.4 DESIGN TIPOGRÁFICO ORIGINAL E ALTERAÇÃO DE FONTE}

EXISTENTE_Paraser considerada uma tipografia customizada original pressupõe-se que ela se trata de um design original projetado a partir esboços preliminares manuais ou digitais. Explora proposições formais

o5 diferentes, que abordam os requisitos referidos no briefing, até chegar ao resultado final. Sua finalidade principal é se alinhar ao discurso corporativo do modo mais direto, dando coesão a todo o sistema de identidade da marca. Em um meio saturado de informações, predominantemente visuais, distinguir a voz de todos os interlocutores é cada vez mais difícil,

10 entretanto, por mais tênue que seja tal distinção, ela pode ser percebida e a voz se faz distinta das demais.

Uma das importantes contribuições que a adoção de uma tipografia institucional personalizada e exclusiva pode trazer, sobretudo para grandes organizações é a mudança na cultura de como esta se apresenta visualmen-

15 te na comunicação textual. Em muitos casos ocorre uma dispersão no uso de fontes diferentes e a introdução de uma tipografia única, que representa os princípios da identidade, agrega caráter a toda informação com seu público externo e a produção documental interna da empresa.

Antes reservada a grandes corporações com condições econômicas

20 para investir em um projeto tipográfico customizado, este, nos dias atuais, é praticamente acessível a instituições de qualquer porte ou até mesmo por indivíduos. Geralmente, o designer de tipos trabalha vinculado a um escritório de design ou empresa de comunicação responsável ou diretamente com o departamento de marketing da instituição. A tipo-

grafia corporativa customizada é uma modalidade com muitas variantes de complexidade e de volume de tempo e trabalho empregado, pois depende de fatores como número de caracteres necessários, desenvolvimento de caracteres especiais, correções óticas para telas de dispositivos digitais (hinting ${ }^{32}$ ), desenvolvimento de tecnologias Open Type ${ }^{33}$ específi-

3o cas e suporte a múltiplos idiomas. Portanto, não convém estimar valores. Ademais, por questões éticas do mercado, esta pesquisa não abor-

32 Hinting: instruçōes matemáticas aplicadas aos vetores de cada caractere de uma fonte, para o tos média resolução em corpos muito pequenos, o que evita distorç̄es indesejadas dos tipos.

3533 OpenTypee (OTF) é um formato de arquivo de fonte multiplataforma, desenvolvido em 1997, como uma extensão do formato True Type Font da Apple (TTF). Suporta até 65.535 glifos, o que permite a inclusão
de diversos idiomas e conjuntos de glifos especiais como versaletes, algarismos minúsculos, fraçōes de diversos idiomase conjuntos de gif 
da noções de custo financeiro real, estratégias de comercialização ou de prospeç̧ão de projetos, focando exclusivamente nos procedimentos, objetivos e condução do design das fontes.

A customização não se aplica apenas aos casos em que um aspecto diferente no desenho das letras é necessário. Alcançar personalidade não é a única prerrogativa de uma fonte customizada. Legibilidade, consistência formal e técnica, flexibilidade e sobretudo, a correta adequação aos princípios da identidade visual são fatores importantes considerar. É apropriado ter um tratamento individualizado nos quesitos funcionais, como espaçamentos ajustados ao uso, nível ideal de legibilidade, visualização (rendering) aprimorada para telas de dispositivos eletrônicos, conjuntos de caracteres especiais (features) para atender ao ajuste fino dos textos, adaptados a cada caso.

Para que o valor desse elemento fundamental da identidade seja compreendido e assimilado como um código visual que reforça a marca é conveniente que a nova fonte seja apresentada para todos os usuários diretos, apresentando sua motivação, características e recomendações de uso e a necessidade de sua adoção generalizada. A inclusão imediat nos Manuais de Identidade Visual ou nos Brand Books colabora para a sedimentação da nova linguagem gráfica.

\section{abcdefgh123 GJKMQRS\& *”}

3.4.1 FF Meta _ Um bom exemplo de uma fonte corporativa customizada é FF Meta (FIGURA 052), que poderia ter sido uma fonte corporativa exclusiva, mas foi abandonada nas últimas etapas do processo. Contudo, tornou-se uma referência em seu tempo e em sua categoria. Além disso, demonstra como um design tipográfico original pode ser constituído sem apresentar uma solução demasiadamente impactante ou nova, mas de extrema funcionalidade e adequada ao seu propósito.
Em fevereiro de 1985 os correios da Alemanha Ocidental, Deutsche Bundespost, contrataram o escritório de design berlinense Sedley Place Design para reformular sua identidade corporativa. Nesse período, as opções tipográficas mais aceitas se resumiam à Helvetica e Univers ou, se 5 necessário um tipo serifado, usava-se a Times New Roman. A popularidade da Helvetica e da Times se dava por razões culturais e principalmente pela alta disponibilidade dos tipos nos sistemas operacionais. Entre as avaliações iniciais, ficou evidente que a Helvetica não cumpria a função de diferenciar a empresa das inúmeras outras que também usavam a mesma fonte, "o resultado é o caos visual ao invés de uma tipografia servir como um denominador comum para todas as comunicações corporativas" (MIDDENDORP; SPIEKERMANN, 2006:20). Como os correios utilizam materiais com tipos em tamanhos muito pequenos compostos em espaçamento entrelinhas muito apertado, impressos em

papéis de qualidade bastante variada e com tintas diferentes também, a Helvetica não era uma boa opção, pois não foi projetada para isso. Apoiados na viabilidade de digitalizar desenhos de letras e obter uma fonte digital, o Bundespost concordou com os designers da Sedley Place em iniciar o projeto de uma fonte customizada, um projeto que foi confiado ao escri20 tório Meta Design e dirigido pelo designer Erik Spiekermann.

De acordo com Middendorp e Spiekermann (2006:21), as instruções iniciais davam conta de que, antes dos fatores estéticos, a fonte deveria suportar difíceis condições de uso. Deveria ser muito legível, especialmente em corpos pequenos; suportar boa leitura em extensos volumes de texto; ser neutra, ou seja, fugir de modismos ou nostalgias; esta disponível em todos os sistemas de composição a um baixo custo; economizar espaço na composição; ter dois pesos claramente distinguiveis ser distinta e inequívoca; e tecnicamente atualizada.

Para definir os conceitos gerais que a fonte deveria ter, Spiekermann e sua equipe empregaram nos primeiros esboços (FIGURA 053) um método mais analítico do que empírico. Pesquisaram seis famílias tipográficas observando pontos de convergência e de divergência entre elas. Foram observadas as proporções elementares da altura-de-x, ascendentes, descendentes, versais e algarismos, espessura das hastes, largura média e uma atenção especial foi dada às formas mais críticas de caracteres semelhantes que se confundem e ao balanceamento espacial das formas e contraformas (FIGURA 054). Dessa análise concluíram que o design $\mathrm{mnm}$ FIGURA 053 Esboço original feito por Erik Spiekermann, em 1985, o qual estuda as proporções básicas da letra minúscula a partir da letra ' $\mathrm{n}$ '.

\section{asshb}

FIGURA 054_Esboço original feito por Spiekermann, em 1985 estuda as contraformas do 'a, $h, b$ ' para optimização das letras em tamanhos muito pequenos. 
deveria envolver, entre outros pontos, os seguintes: ser uma tipografia o sem serifas, caso contrário causaria um choque muito forte na cultura conservadora da empresa; ter uma proporção mais estreita, mas não uma versão condensada de uma fonte existente; as hastes principais deveriam ser grossas o suficiente para suportar impressões em superfícies grosseiras, como papéis reciclados, por exemplo; os caracteres deveriam ter certa individualidade para evitar ambiguidades, mas sem exageros; altura-de-x maior; algarismos deveriam ser claramente distintos entre si e um pouco mais baixos que as maiúsculas; curvas deveriam equilibrar a tensão entre linhas externas mais suaves e linhas internas mais 'quadradas' para incrementar a clareza e legibilidade (Ibid.:22). Os autores concordaram que esse resultado estava em sintonia com as recomendações do briefing ${ }^{34}$ e apontava na direção de um design austero funcional, bem como levemente humanista e sensível. Após os esboços darem forma às letras e serem digitalizados como uma fonte digital pelo aplicativo Ikarus ${ }^{\oplus 35}$, a tipografia foi batizada de PT55. Para fornecer uma diversidade suficiente para as necessidades hierárquicas nos textos, três estilos foram desenhados: regular, regular italic e bold. Os pesos regular bold foram desenhados manualmente e o itálico, gerado por interpolação ${ }^{36}$. Em seguida, foi necessário criar um peso intermediário para um melhor desempenho em sistemas de sinalização, letreiramento arquitetônico, veículos e aplicações em títulos grandes. Ainda, muitos sinais especiais como pictogramas, símbolos e inclusive o próprio logotipo do Deutsche Bundespost, poderiam ser incluídos no software da fonte, eliminando a necessidade de reproduções fotográficas para aplicação 25 em artes finais.

Finalizada, a PT55 foi testada em materiais gráficos do novo projeto gráfico desenvolvido pela Sedley Place. O resultado foi uma fonte cujo grau de condensação permitia boa economia de espaço na página e uma excelente qualidade de impressão em corpos pequenos, além de 30

34 Briefing: conjunto de informaçōes dadas a alguém antes de fazer algo, ou a reunião em que isso contece. Information that is given to someone just before they do something, or a meeting where this Therus um marco da

em 1974 pelo Dr Peter Karow Já permitígorafia, ú um programa para desenhar e gerar tipos digitais criado pela indústria tipográfica até o final dos anos 1980 (BAINES HASLAN, 2002:114)

36 Interpolaçăo: método utilizado para gerar pesos intermediários entre dois valores básicos, após o qual as fontes produzidas automaticamente são aperfeiçoadas manualmente (LUCAS FonTs, S.D.P.
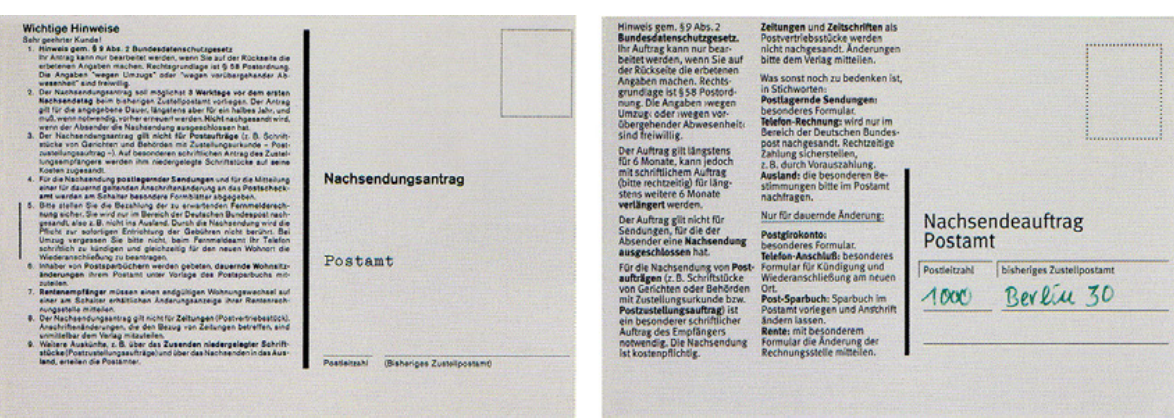

contribuir com um caráter próprio e evidente, como pode ser visto na simulação em um cartão postal (FIGURA 055).

O departamento de publicidade do Bundespost, que havia sinalizado pela execução do projeto tipográfico, queria implementá-la de imediato, mas, inesperadamente, a administração da empresa abortou a ideia de assumir uma tipografia corporativa exclusiva, alegando que

isso "causaria desconforto" entre seus usuários e manteve a Helvetica, com todas suas variantes e problemas de aplicação. Em 1991 a tipografia, então rebatizada como Meta Bleifrei, foi adotada por Spiekermann como a tipografia corporativa de seu próprio escritório, a Meta Design. Incorporou-se ao catálogo da type foundry FontFont como FF Meta, a

20 primeira fonte sem serifas projetada para comunicações corporativas, com vendas tão expressivas que foi considerada a 'Helvetica dos anos 1990" (SPIERKERMANN, 2011:67).

3.4.2 Nokia Sans e Nokia Serif_ Do mesmo designer, vieram outras

fontes corporativas como a Bosch, de 2005 e a família Nokia, em 2002 Tipografia composta por 12 fontes que variavam em proporção, peso e na estrutura serifada e sem serifas. Sua premissa fundamental é a legibilidade. A família foi pensada para funcionar tanto em ambientes gráficos como em dispositivos com telas muito pequenas e de baixa resolução e

30 manter o reconhecimento do design mesmo em 8 pixels de tamanho. Ao ligar um aparelho de celular e, mesmo que o logotipo Nokia logo desapareça, os ícones e a tipografia dos textos cumprem a função de manter a marca presente. Apesar de cada série de tipos sans, sans wide, sans condensed, sans title e serif ter sido desenhada para atender a aplica-

35 ções específicas como títulos, textos longos corporativos e publicitários, dispositivos de baixa resolução, embalagens etc todas compartilham das mesmas características e mantêm uma imagem forte do conjunto
FIGURA 055_Cartões postais antes, à esquerda, e depois, à direitc. apesar do conteúdo dos dois exemplares serem diferentes, o que dificulta uma comparação mais exa de rendimento, é evidente o bom desempenho da PT55 (Meta) na nova proposta gráfica para impressos. 


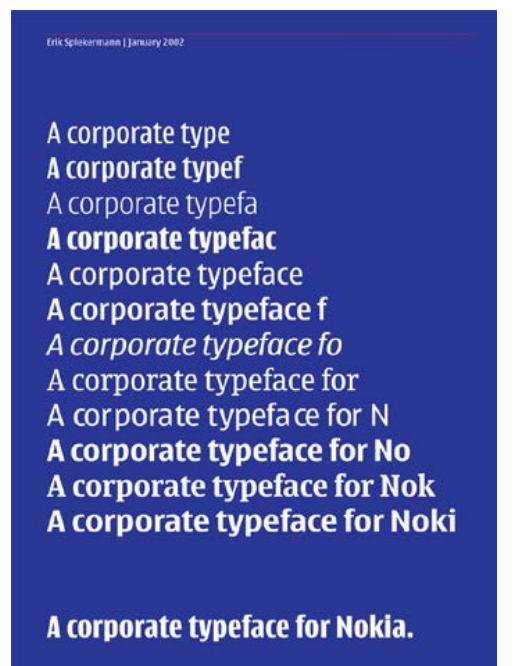

todas as versões podem ser usadas na mesma linha ou parágrafos de textos, fortalecendo a linguagem visual da empresa (FIGURA 056). Para atender ao melhor desempenho em tamanhos muito pequenos, as hastes e curvas são ligeiramente contrastadas e a altura-de-x é muito alta. Se comparada com outras tipografias usadas até então, no mesmo tamanho óptico, a fonte Nokia é predominantemente condensada e ocupa menos espaço na composição das publicações, o que, segundo o designer representa uma economia de 12\% (SPIEKERMANN, 2002:4). Em entrevista à revista japonesa PingMag, Spiekermann relata a abordagem do design pensado para otimizar a legibilidade:

Bem, como em todas as letras, o importante é você realmente não desenhar a parte preta das formas, mas a branca: o espaço no seu interior e o espaço ao redor. Isso é muito importante. Se você aplicar isso às fontes para tela, você pode fazer uma fonte realmente legível. (...) nós lemos contraste, lemos ritmo, negros e brancos, o de dentro e o de fora, 0 topo e a base das formas (PINGMAG, 2005, s.n. - tradução minha $\left.{ }^{37}\right)$.

\section{response rate of 77 percent, wide opinion survey of all Nokia employees. This is}

ndividualmente, os caracteres exploram contraformas abertas, com as curvaturas abertas bastante planas como no 'a, c, e, g, s', as incisões angulares no 'a, d, n, p, r' auxiliam a distinção das formas e a ausência de espora no ' b', o que os diferencia claramente de outras formas e lhes dá personalidade. Mesmo na versão serifada, a legibilidade é garantida por serifas curtas, levemente triangulares e sem junção curva (FIGURA 057).

the space insidid it and the spacce around it. That is very important. If you apply that to screenfonts, you can make a really legible screenfont" (PINGMAG, 2005)
3.4.3 Audi Type Na a celebração dos 100 anos da fabricante de automóveis Audi, o escritório Meta Design foi selecionado para renovar a identidade visual e incumbiu os designers holandeses Paul van der Laan, da Type Invaders e Pieter van Rosmalen, da Caketype, de desenhar uma nova tipografia corporativa para a montadora. Antes, era usada uma versão modificada da Univers Extended, a então chamada Aud Sans (FIGURA 058) introduzida pela própria Meta Design em 1997 que

\section{Audi Sport Audi Sport}

FIGURA 058_Comparação entre a fontes a Audy Sans e a Audi Type (embaixo), que atribui ganho em

não era usada no logotipo (FIGURA 059). Apesar de o design ter sido construído a partir do zero, o novo projeto preocupou-se em preserva alguma semelhança com base estrutural da tipografia anterior, como a largura dos caracteres (proporção), espacejamento (métrica) e peso (cor do texto), mantendo os aspectos subjetivos de dinamismo, sofisticação e alta performance. Sobre isso, os arquivos das fontes, distribuídos gratuitamente, têm uma inusitada descrição no campo reservado a avisos: “[...] esta família tipográfica representa autoconfiança, dinamismo e estilo, combinados à atenção meticulosa ao detalhe" ${ }^{{ }^{38}}$. As versões normal e bold são ligeiramente mais pesadas e as ascendentes descendentes são um pouco mais longas, o que atribui certa robustez e melhora o desempenho e legibilidade em corpos pequenos. As aberturas são mais amplas como no 'a, c, e, g, s', as contraformas de 'b, d, g, p, q' são diferentes do 'o' o que garante melhor diferenciação. Os caracteres mais marcantes são ' $\mathrm{l}$ ', com o detalhe curvo no terminal inferior, o 'M' com o vértice mais curto, o 'I' com serifas e o 'G' sem a barra e sem apoio. A nova família tipográfica lançada em 2009, a Audi Type, participa ativamente

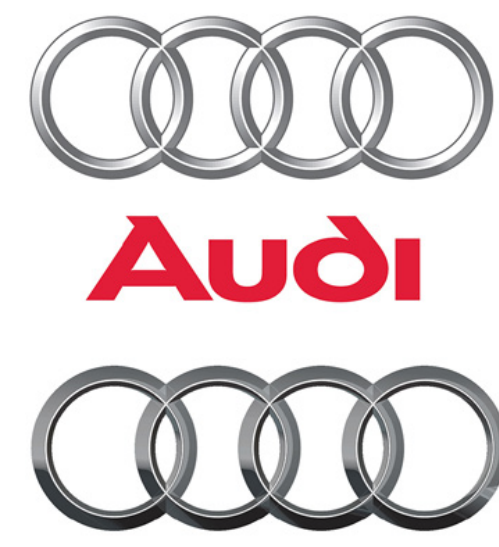

Audi

FIGURA 059_A marca da Audi de 1987 em cima, não utilizava a tipografia Audi Sans. Com o novo design de 2009, embaixo, o logotipo da marca, menor, recebe a fonte corporativa Audi Type. 
AUDI type normal

ACEGKMORSVXYabcdefghjklorstuvy AUDI type italic

ACEGKMORSVXYabcdefghjklorstuvy

da arquitetura da marca ao relacionar de modo intuitivo e lógico todas as subsidiárias e bases de negócio espalhadas pelo mundo com a marca Audi. ACEGKMORSVXYabcdefghjklorstuvy É composta de oito estilos - Audi Type Extended AUDI type bold italic

E composta de oito estilos - Audi Type Extended
Bold, Audi Type Extended Normal, Audy Type Bold e Audi Type Normal, com seus respectivos ACEGKMORSVXYabcdefghjklorstuvy AUDI type extended normal ACEGKMORSVXYabcdefghjklorstuvy AUDI type extended italic itálicos (FIGURA 060). Versões completas para os idiomas cirílico e grego foram acrescentadas em seguida. Além da incorporação da nova fonte ao logotipo (FIGURA 059), a família é utilizada em todo ACEGKMORSVXYabcdefghjklorstuvy AUDI type extended bold logotipo (FGURA 059), a familia é utilizada em todo ACEGKMORSVXYabcdefghjklorstuvy o material de comunicação, desde brochuras AUDI type extended bold italic anúncios publicitários até os painéis digitais de ACEGKMORSVXYabcdefghjklorstuvy bordo dos automóveis.

FiguRA 060 Familia Audy Type composta de quatro pesos com respectivas itálicas.

3.4.4 ČD Fedra_Uma tipografia pode ser alterada em diferentes níveis, para se adequar a alguma necessidade do design corporativo ou se diferenciar da fonte original comercializada no mercado. As modificações podem ser muito sutis ou alterar de forma mais significativa o design da fonte, ajustando esta em seu peso, eixo, inclinação, serifas, proporção (condensação ou expansão) ou na correção na estrutura de algumas letras. A principal questão envolvida nas modificações reside na aproximação do design das letras com os valores visuais da marca ou logotipo. Porém, há uma questão legal de propriedade intelectual do design. Designers frequentemente elaboram logotipos alterando as formas vetorizadas de uma determinada fonte, o que é válido. O que não é permitido é que essas letras sejam posteriormente convertidas em uma nova tipografia exceto se houver o consentimento comprovado do autor ou proprietário dos direitos da fonte que deu origem ao design modificado. Portanto, esta modalidade é processada em fontes do catálogo da própria type foundry, gerando uma nova fonte e licenças de uso apropriadas, ou em outras fontes do mercado mediante autorização para isso, sem comprometer nenhum valor ético ou violação de direitos autorais. Situação muito comum que, acima de tudo, economiza tempo investimento, é quando a instituição seleciona uma fonte do catálogo de uma type foundry e, a partir dela, são feitas intervenções que se adequam aos requisitos da marca. Um exemplo dessa mudança sutil no design pode ser observado na versão da fonte Fedra Sans para a

\section{REKLAMNÍ MAGAZİN ČESKȲCH DRAH}

companhia ferroviária tcheca České dráhy. O redesign da identidade da empresa foi conduzido em 2009 pelo Studio Najbrt, que solicitou ao designer de tipos holandês Peter Bil'ak uma versão de sua fonte Fedra (FIGURA 061). Nesta, apenas foi acrescentada uma serifa slab no topo esquerdo de algumas maiúsculas, como no 'B, D, E, F, P, R', para criar alguma particularidade no alfabeto institucional da companhia.

3.4.5 Xerox Sans Outro caso semelhante foi o da fonte Xerox San para a Xerox Corporation, desenvolvida pelos designers da inglesa Fontsmith. Em 2007, após quase 40 anos, a empresa passou por uma reformulação geral de sua marca a cargo da agência nova-iorquina

5 Interbrand, o que incluía uma tipografia corporativa exclusiva (FIGURA 062). Na fase inicial, tratou-se de testar algumas fontes do catálogo da Fontsmith com os principais atributos que representavam o novo direcionamento da marca Xerox, como a fonte Fs Albert (FIGURA 063) cujas proporções e curvaturas de características mais humanas se 20 aproximavam do logotipo. Ela foi reformulada para criar um caráter único e carregar mais claramente as noções da marca. Alguns caracteres foram muito sutilmente modificados, como o terminal inferior curvado

\section{Charismatic Warm Friendly Elegant Sensitive Vibrant Robust Flexible Dependable}

do 'l' para ganhar a singularidade desejada e versões condensadas completas da família e versaletes também foram acrescentados. Devido à projeção global da empresa, complementações idiomáticas foram feitas 5 para cirílico, grego e todos os idiomas europeus, alcançando 90 línguas diferentes (FONTSMITH, s.d.).
FIGURA 063 Tipografia FS Albert associada a atributos emocionais da marca Xerox. 
FIGURA 064_Página dojornal modificada a partir da fonte Abril Text da type foundry TypeTogether, em 2013.

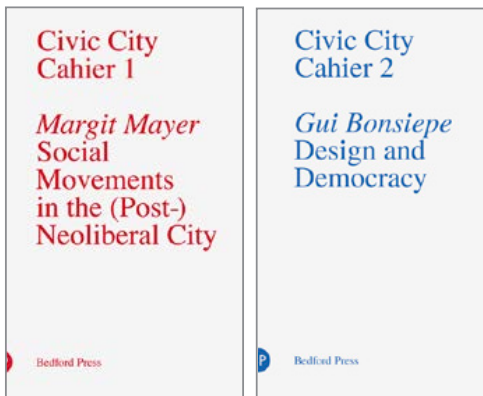

FIGURA 065_Capas da $1^{a}$ edição de Setembro de zo10 e da $2^{a}$ edição da revista Civic City Cahier com a fonte Times Roman.
3.4.6 Almería_Outro exemplo de tipografia modificada é o projeto para o novo design do jornal espanhol La Voz de Almería, conduzido em 2013 pelo escritório de consultoria Cases | Associates, comandado pela diretora de arte Violeta Valle. A tipografia Almería foi desenvolvida para os títulos pela type foundry espanhola Typetogether, com os designers Veronika Burian e JoséScaglione. Almería foi baseada na fonte Abril Text cujo design por sua vez, foi baseado em uma releitura do estilo clássico das Didone

\section{Treinta madres
se unen por una
educación para
sus hijos distinta}

e nos tipos romanos escoceses de serifas quadradas do século xIX e que foi refinada e ajustada para os títulos e subtítulos do jornal, além de pequenas alterações no contraste e proporções para alcançar a cor e textura ideais (TYPETOGETHER, s.d). Os remates das letras 'a, c, f, r, j, y' são pronunciados e os tratamentos dados às curvas nas itálicas são fluídos e muito característicos, o que confere ao periódico uma atmosfera de tradição e densidade de conteúdo associada a detalhes mais descontraídos aplicados nas curvas e remates (FIGURA 064).

3.4.7 Axe Times_Uma tipografia criada a partir de uma modificação de um clássico da tipografia, a Times New Roman, foi realizada para séri de publicações Civic City Cahier. A coleção da editora londrina Bedford Press aborda temas relacionados ao design, com textos produzidos por autores convidados, com o objetivo de gerar material para discussões críticas sobre o papel social do design. Sua primeira edição em setembro de 2010 traz na capa uma composição monocromática direta, simples, e totalmente tipográfica, composta pela fonte Times Roman da Linotype (FIGURA 065). Esse design é mantido, ao menos, pelas próximas cinco edições que se diferenciam pela cor e pequenas e sucessivas modificações na tipografia. A segunda edição da revista já traz as primeiras e suti modificações na Times New Roman cuja intervenção mais evidente o pingo do 'i', ligeiramente ampliado e transformado em um losango.

Cinco escritórios de design alemães colaboraram com o projeto: Studio Görlich, Milieu Grotesque, Last Minute Panic, Laqshmi Manolete Pellegrin e Studio Tobias Becker. Este último desenvolveu uma versão muito diferente da referência original, a Axe Times, composta de quatro estilos: regular, italic, bold (FIGURA 066) e bold italic. No design, as diagonais do ' $w$ ' se cruzam e o cume das diagonais internas do ' $W$ ' mais baixo; a barra do 'A' é dobrada, ao estilo das inscrições da Europa cristã do século viI. A terceira edição efetiva outra alteração mais estrutural nas hastes, abrindo algumas conexões nas letras 'a, e, d, b, p, q, k P, R' por exemplo, criando um efeito estêncil nas formas (FIGURA 067).

Na quarta edição, as intervenções chegam a um ponto máximo com transformação das serifas transicionais da Times New Roman em serifas lapidares (triangulares) nas hastes e de remates de aspecto serifado inclinado substituindo as gotas originais. $O$ ' $M$ ' apresenta hastes laterais bastante inclinadas, aproximando-se da Capitalis Monumentalis 20 romanas (FIGURA 068).

$O$ resultado transparece certa inconsistência no design geral das letras: as serifas não estão equalizadas e são mais pesadas que a própria haste; os remates das curvas não seguem a mesma agudez das serifas. A edição seguinte retorna ao estágio anterior da fonte (usada na

terceira edição), mas acrescenta uma ligatura não usual no 'wy'. A sexta edição utiliza novamente a Axe Times com outras pequenas variações, como a barra no ' $z$ ' itálico e o ' $\&$ ' mais curvilíneo. Esse exemplo retrata um projeto que começou como uma simples modificação que foi, por sucessivos processos de elaboração, transformando-se em uma tipografia bastante diferente da referência inicial.

Por princípio, as alterações de fontes envolvem intervenções muito pequenas no desenho das letras com a finalidade de criar alguma personalização, como a ČD Fedra. Há casos, porém, em que essas operações quase ultrapassam o limite da preservação do design original e podem

se tornar uma fonte bem diferente, aproximando-se de um design original, como no caso da Axe Times. De modo geral, uma tipografia alterada ou simplesmente ajustada é uma situação mais adequada para
Axe Times Regular Axe Times Italic Axe Times Bold Axe Times Italic

FIGURA 066_ Tipografia Axe Times em suas versões regular $e$ bold com seus itálicos.

\section{ABCDEFGHIJ KLMNOPQRS TUVWXYZ} abcdefghijklmn opqrstuvw x yz 0123456789 !? $(. ;: ;) \backslash / \bullet \ldots$, , $\# \ll »+\& \mathbb{I} \S ¥ \$$

FIGURA 067 Alfabeto da tipografia Axe Times Regular.

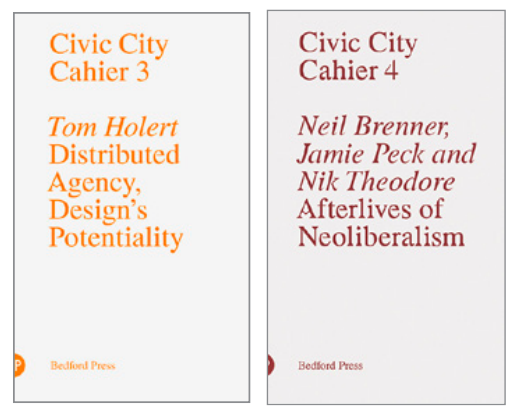

FIGURA 068 Capas da $3^{a} e 4^{a}$ edição da revista com a fonte Axe Times, última apresenta serifas lapidares. 
instituições que necessitam de uma fonte minimamente personalizada, o1 em um prazo de tempo muito curto e a custos mais baixos, pois estas aproveitam um design já estruturado e tecnicamente ajustado.

3.5 CUSTOMIZAÇÃO, MODIFICAÇÃO E COMPLEMENTAÇÃO

\section{A ferta de projetos corporativos oferecidos pelas type foundries, abran-} gem desde a concepção, projeto e implantação de tipografias exclusivas e ajustadas a um uso determinado, até a consultoria em assuntos como licenciamento, legislação, distribuição e questões técnicas específicas. As fontes customizadas não seguem uma nomenclatura ou classificação comum ou padronizada para designar tal atividade. Observando como as grandes e médias empresas de design de tipos digitais se referem aos respectivos portfólios de serviços (TypeTogether, Dalton Maag Hoefler \& Co., Monotype, Linotype, LucasFonts, FontSmith) quando se apresentam, nota-se a preocupação em simplificar o vocabulário para facilitar a compreensão do público sem, contudo, deixar de mostrar variado painel de opções e a abrangência de serviços que o designer pode oferecer

Mesmo se tratando de projetos executados sob uma demanda espe- 20 cífica e agrupados sob o termo genérico de Custom Fonts, de modo geral, separam a tarefa em duas modalidades principais: a customização de fato, ou seja, tipografias criadas a partir de desenhos totalmente originais, e modificação, que compreende a alteração de algum aspecto formal ou técnico na estrutura atual de uma fonte, como as possibilidades de alteração de fontes relatadas anteriormente. Essa divisão se justifica, pois se considerarmos uma fonte tipográfica como um software, qualquer alteração em seu conteúdo será tomada como uma modificação.

Reunindo as opções apresentadas nos descritivos online das atividades de type foundries, a segunda categoria foi dividida em uma terceira, complementação, porque, apesar de não envolver totalmente um novo design, também não trata apenas de modificar uma fonte já existente, pois agrega novos conjuntos de caracteres ou versões inteiras de estilos que não faziam parte da fonte e que exigem um trabalho criativo maior do designer. Em vista disso, e ressalvando o sentido genérico do termo 35 'customização', propõe-se classificar o assunto em três categorias:

\section{CUSTOMIZAÇÃO}

Criação de fontes originais para uso (inicialmente) exclusivo.

. Fonte customizada original (from scratch, bespoke, taylor made)

5 Um design completamente novo criado pelo designer de tipos ou type foundry. Concebida e desenhada a partir de premissas elaboradas para atender demandas da comunicação visual ou de ordem identitária de uma instituição, em que a originalidade e exclusividade são fatores significativos. Normalmente, é ampliada para uma família tipográfica,

- com vários estilos (pesos, itálicos, proporções etc.) e usada como tipografia institucional que dá sustentação à marca ou adquire a própria função de "marcar". Os direitos de uso exclusivo podem ser por tempo limitado ou ilimitado, variando seu custo final.

15 b. Fontes customizadas de logotipo

Desenvolvimento de tipografia digital, com caracteres completos, a partir do design das letras que compõem o logotipo da instituição. Considera-se que o logotipo seja composto por letras cujo design tenha alguma personalização.

\section{c. Fontes a partir de esboço de alfabeto fornecido}

Digitalização e geração de fonte tipográfica completa a partir de desenhos manuais ou esboços digitais (layouts) de alfabetos cuja quantidade de informação e de caracteres desenhados varia. Esta modalidade é, geralmente, solicitada por designers e artistas gráficos não especializados em tipografia ou por escritórios de design que recomendam em seus projetos uma tipografia exclusiva por meio de um esboço das letras que, posteriormente, são finalizadas por um designer de tipos. São comuns alterações no design fornecido e complementa3o ç̃̃es do projeto original com mais caracteres e outros estilos. 


\section{MODIFICAÇÃO}

Alteração, redesenho, adaptação ou correção de fontes já existentes.

\section{d. Fontes modificadas ou adaptadas}

Uma fonte distribuída comercialmente é alterada ou ajustada em dife- 05 rentesníveis de profundidade, mas mantendosempreseuaspectogeral. Porém, levam-se em conta todas as regras de licenciamento comercial da fonte para preservar os devidos direitos de propriedade intelectual.

e. Revitalização ou reinterpretação de tipos históricos (Revivals) Tipos ou fontes historicamente relevantes e bem-sucedidos são redesenhados para se adaptarem a novos suportes e restrições técnicas ou simplesmente, por questões estéticas. O mesmo pode ser feito para tipos antigos impressos ou letras desenhadas manualmente que não foram digitalizados e convertidos em fontes.

\section{f. Correção de parâmetros métricos}

Os alinhamentos, espaço de entrelinhas, espaçamentos entre letras e espaçamentos entre pares de letras (kerning) são revisados e adaptados ao propósito de uso. Por exemplo, uma tipografia usada 2 em projetos de sinalização deve ter seu espaçamento ajustado para a distância de leitura ideal e tamanho das letras, ou letras para títulos que precisam ter seus espaçamento reduzido.

\section{g. Conversão de Formato}

Fontes antigas (True Type Font, Type 1, Post Script, Multiple Master, Bitmapped, F3, Intellifont, etc. ) são convertidas e adaptadas a formatos mais modernos e multiplataformas como o Open Type Forma (OTF) ou formatos para web como Web Open Font Format (WOFF) Embedded OpenType (EOT)

\section{h. Optimização para Telas - Hinting}

Para melhor visualização em telas de dispositivos eletrônicos (TV, monitor de computador, celulares, jogos eletrônicos, telões e telas LED de rolagem, etc.), a programação da fonte que traduz as informações dos vetores em pixels, é ajustada para um desempenho melhorado em telas especialmente aquelas de baixa resolução.

\section{COMPLEMENTAÇÃO}

Acréscimo de caracteres, grupos de caracteres ou

estilos inteiros de fontes existentes.

\section{i. Extensão de Caracteres}

Fontes com conjuntos limitados de caracteres são complementadas com sinais diacríticos, sinais de marcação, pontuação, sinais monetários, sinais de indicação (setas, bullets, bordas), sinais iconográficos (dingbats), etc. Criação de conjuntos de caracteres especiais integrados à fonte original para uso em Open Type, como ligaturas (ligatures), versaletes (small caps), algarismos não alinhados (old style) e tabulares, ornamentações (swashes), frações e sinais monetários capitulares para títulos (titling), incluindo a codificação para Open Type.

\section{5 j. Extensão Linguística}

O conjunto de caracteres de uma fonte Open Type existente é ampliado para suportar diferentes idiomas como os dos países da Europa Central, além do cirílico, grego, coreano, chinês, árabe, hebraico etc.;

\section{0 k. Extensão da Família}

Desenvolvimento de novos estilos como pesos (bold, light, extralight, semi-bold, etc.), Itálicos, proporções (condensado, expandido, ultracondensado, etc.).

\section{Inclusão de caractere com logotipo e símbolo}

Geração de fonte com os caracteres que compõem o logotipo para que ao digitar o nome da instituição e aplicar a fonte, o logotipo seja gerado imediatamente, preservando as características da marca e o espaçamento entreletras. $O$ desenho do símbolo da marca também pode ser so incorporado à fonte como um caractere alternativo.

Cabe citar que nem sempre os projetos tipográficos são inteiramente identificados por uma ou outra forma. Os itens das três categorias podem ocorrer simultaneamente, acumulando ações que tanto modificam a

35 fonte como também a complementam ou o projeto pode começar como uma modificação e se transformar em um projeto original, com resquícios da fonte modificada. 
3.6 AVALIAÇÕES PRELIMINARES AO PROJETO_ Quando uma instituição determina novas diretrizes em sua comunicação que afetam ou redirecionam o posicionamento de sua identidade, deflagra uma sequência de ações que exigirão também a reestruturação completa do design. Nesta etapa de elaboração da mensagem essencial da marca, alguns conceitos são elencados para orientar o encaminhamento das propostas do novo design. Palavras-chave ou sínteses conceituais que servem de referência para um tema, são muito comuns na composição de briefings para nortear suscintamente o trabalho do designer, o qual precisa estar atento também a outras questões prévias que consolidam os objetivos primários. De acordo com a avaliação prévia que Jorge Frascara (2006:69) recomenda em relação a projetos de comunicação e design gráfico, e com os procedimentos específicos adotados por designers de tipos (HENESTROSA, MESEGUER e SCAGLIONE, 2012:11-13), uma lista de questionamentos deve ser considerada juntamente com os pontos colocados pelo briefing:

\section{Questionamentos preliminares}

a. Contexto interno: ainda que os conceitos-chave da nova proposição devam ser tomados como premissas, o projeto precisa ser coerente com a marca (brand) e pode refletir valores mais históricos ou tradicionais que assegurem alguma continuidade à identidade da instituição; observância da memória gráfica e outras referências relevantes.

b. Contexto do uso aplicado: $O$ designer deve analisar os suportes materiais ou digitais nos quais a fonte será mais frequentemente utilizada e as condições de leitura. Situações exemplares são as aplicação em materiais de sinalização, impressão em papéis específicos para jornais, livros e revistas, uso em telas de grandes dimensões ou com resolução 30 muito baixa.

c. Contexto do público alvo: na grande maioria dos casos, uma tipografia deve ser abrangente e poder comunicar facilmente com diversos tipos de usuário/leitores. Os níveis de legibilidade, visibilidade ou leiturabilidade ${ }^{39}$, variedade de idiomas que a fonte deve suportar estão diretamente relacionados a esse ponto.

d. Contexto do usuário: o projeto deve contemplar a prática e as exigências daqueles que utilizarão as fontes com mais frequência. Peculiaridades estéticas ou técnicas podem ser projetadas especificamente para tipos de usuários diferentes. Normalmente, três grupos distintos serão usuários da fonte exclusiva, dois diretos e um indireto. Os usuários diretos são os funcionários administrativos e a equipe de 10 designers e profissionais de comunicação. Usuários indiretos são os fornecedores de materiais gráficos ou digitais que necessitam manipular arquivos gerados pelos usuários diretos.

e. Personalização: há algum elemento/caractere que pode ou precisa personalizar o design da fonte de maneira mais enfática e clara? Além dessa possibilidade, a tecnologia Open Type permite inserir caracteres especiais ou alternativos e modificar o comportamento da fonte ao escrever.

20 f. Suporte idiomático: se a atuação da instituição apontar para outras regiões culturais além daquela à qual pertence, séries completas de alfabetos de diferentes idiomas devem fazer parte do conjunto de caracteres da fonte, muitas desses, envolvendo complexos sistemas de escrita.

g. Flexibilidade de Estilos: avaliar a necessidade de variedade de estilos como tipos serifados, semiserifados e sem serifas; bold, black, semibold itálicos; condensações e expansões; versaletes e algarismos minúsculos (OSF), etc.

h. Recursos Técnicos: dependendo da finalidade principal da tipografia, certos parâmetros formais e técnicos já podem ser definidos como o peso das letras, proporção, ligaturas, grupos de caracteres especiais e outros recursos mais específicos.

39 Leiturabilidade: neologismo proposto para traduzir o termo inglês readbility, refere-se ao grau de conforto visual da tipografia na leitura, especialmente em textos longos; "A capacidade de uma determinada fonte de dar forma a um texto sem requerer esforço adicional do leitor" (EARIAS, 2002:26-28. 
i. Planejamento de Implantação: requer a avaliação da quantidade e diversidade dos dispositivos nos quais a fonte deverá ser instalada. Em ambientes de produção mais complexos, como uma grande editoria de jornais, a implantação precisa ser testada em todas as instâncias e pode ser conduzida de modo gradual garantindo total compatibilidade com os sistemas de produção. Se a fonte contiver recursos especiais (Open Type Features ${ }^{40}$ ou outros), alguma instrução de uso para os usuários deve estar prevista. Nesta etapa, deve-se atentar para que a fonte desempenhe seu papel de maneira uniforme e fluida nos vários ambientes gráficos e digitais.

j. Distribuição: se for necessário que os usuários da fonte a acessem a distância (por download), procedimentos de segurança precisam ser programados para evitar que a fonte seja disseminada indevidamente.

Um projeto tipográfico voltado para a construção de uma identidade não pode se resumir a uma abordagem meramente funcionalista preocupada apenas em atender demandas técnicas como legibilidade ou variações de estilo, por exemplo. O processo deve envolver questionamentos sobre as propriedades da identidade, níveis de diferencia- 20 ção necessários, a história da instituição e seu contexto na sociedade. As identidades visuais pretendem criar uma situação de continuidade e reconhecimento de suas mensagens, e a tipografia pode multiplicar a eficiência nessas ações. Uma tipografia corporativa só alcançará seu objetivo de perdurar se combinar a consistência técnica, as aspirações do cliente e o histórico cultural da instituição.

Open Type Features ou orf: dentro da capacidade de uma fonte acomodar 65.535 caracteres, as fontes de padrāo Open Type (1997) podem incorporar, em um mesmo arquivo, vários idiomas e caracteres programaçăo que fornecem ao usuário a a cesso integrado a certos refinamentos tipográficos - como versaletes, caracteres alternativo, ornamentos, bordas, fraçōes e outras, - sem alterar a fonte ou interromper a codificação de texto subjacente.

\subsection{PROCEDIMENTOS GERAIS DE DESENVOLVIMENTO DE}

UMA FONTE CUSTOMIZADA_Um projeto tipográfico baseado en proposições comissionadas, não autorais, recebem premissas conceituais e técnicas estipuladas pelo seu contratante e isso é traduzido nas

o5 formas das letras. Considerando a diversidade de projetos, distribuídos em diferentes níveis de profundidade e extensão, os meios e processos empregados pelos designers de tipos são relativamente semelhantes. Baseando-se em apresentações disponíveis nos websites e nos catálogos de diversas type foundries, além das informações obtidas com designers

10 de tipos, brasileiros e internacionais, identificam-se algumas variantes que modificam o encadeamento das ações envolvidas no projeto, mas nada que altere substancialmente a lógica da criação e da produção. Os projetos iniciam com a observância dos requisitos e atributos que a fonte deve ter, indicados pela própria instituição ou pela sua equipe de

15 marketing ou design responsável. Esta etapa pode ser muito específica ou consideravelmente genérica. Como bem exemplifica o designer gráfi co e tipográfico mexicano Cristóbal Henestrosa:

No início é o conceito. Pode ser uma proposição tão simples como: 'quero uma família de texto para compor livros', ou uma mais específica: 'quero uma família de texto para compor livros sobre história do México, particularmente em latim, espanhol e náuatle'. A isso pode-se somar definiçōes sobre o público-alvo, sobre como os livros serão diferenciados em relação a outros similares no mercado, sobre o que essa família que oferecerá que não pode ser encontrado em outros lugares, etc (HENESTROSA, MESEGUER e SCAGLIONE, 2012:15).

3.7.1 0 briefing_As diretrizes criativas e colocações de ordem operacionais e técnicas, também podem revelar indicações que sirvam de ponto 3o de partida para pesquisas e coleta de informações passíveis de incorporação ao projeto. No caso de um projeto subordinado a uma nova identidade corporativa, todas as etapas estão constantemente referenciadas à conceituação da marca e aos seus atributos. Não são raras, nos briefings, alusões a estruturas arquitetônicas, aspectos paisagísticos locais 35 ou outros fatores culturais que são importantes no processo intuitivo da criação de certas formas, como ocorreu na tipografia desenvolvida pela type foundry Dalton Maag para os Jogos Olímpicos do Rio de Janeiro 
FIGURA 069_Os conceitos-chave ea tipografia para as olimpíadas Dalton Maag, em 2012. Rio 2016, realizada pela type foundry

\section{Diversidade Espúnito Harmônica Olimpico Energia Natureza Contagiante Transformação}

2016, por exemplo. Os conceitos paixão e transformação guiaram o todo o projeto gráfico, desde a criação da marca, na tentativa de representar a índole festiva e calorosa do brasileiro e a força do esporte como agente transformador social (FIGURA 069).

Tomando como referência as letras do logotipo, criado pelo escritório carioca Tátil Design em 2010 e sob coordenação do designer Fabio Lopez a equipe brasileira da Dalton Maag, formada por Fábio Haag e Fernado Caro, criou as formas das letras do alfabeto tomando emprestadas as curvas do grafismo que compõe as calçadas nas ruas do bairro de Copacabana. Os contornos típicos dos morros cariocas, as linhas do horizonte local ou o próprio movimento de atletas durante suas práticas esportivas estão representados no design da tipografia pelos traços contínuos e irregulares, pelo aspecto curvilíneo das hastes e remates, pela a ausência de serifa e pela postura cambaleante das letras, que dão uma conotação de informalidade e movimento quase dançante às palavras (FIGURA 070).
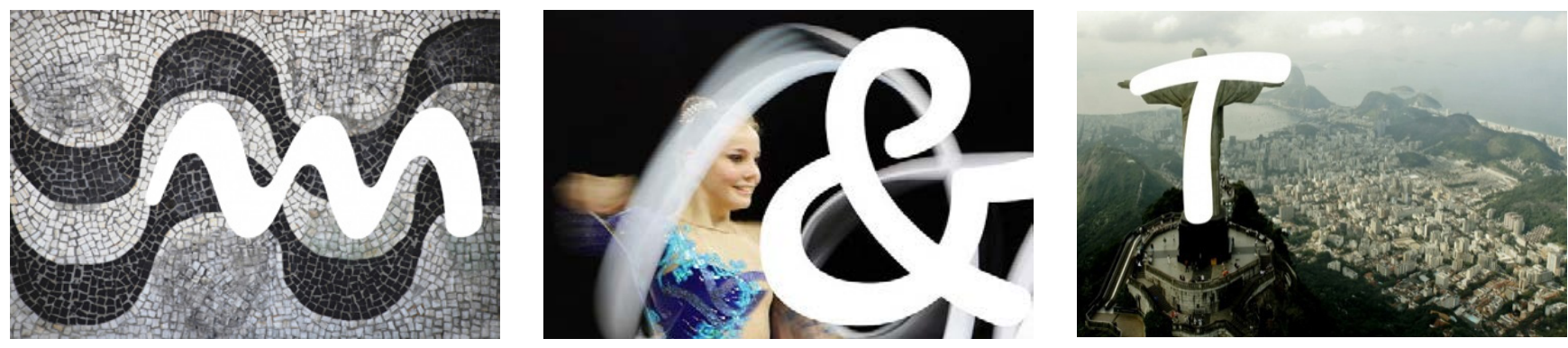

FIGURA 070_O grafismo urbano e paisagens da cidade inspiraram as

formas da tipografia.

Após a apresentação do briefing ou até mesmo durante esse contato com o cliente, o designer já imagina como deve ser o design em questões formais genéricas e a personalidade que responderá aos quesitos apresen-tados. Evidentemente, esse momento não é guiado pela intuição aleatória ou por insights inexplicáveis. A memória, que acumula o repertório gráfico, referências históricas em livros, exemplares impressos ou inscri- ções, age como desencadeador criativo que embasará muitas decisões no design. O designer Gerard Unger aponta que uma ideia deve estar nitidamente formada em sua mente logo no início do processo:

Uma cor pode atrair você. "Cor" é uma parte curiosa da terminologia tipográfica: aqui não tem nada a ver com a cor no sentido usual. Em vez disso, ela descreve o tom geral de preto que um texto impresso parece ter - a impressão geral, se preferir. Esse é o resultado da média visual de formas arrojadas, leves ou pesadas, formas espaçosas. Você pode decidir por formas amplas e arredondadas ou escolher outra direção e optar por letras mais estreitas. A atmosfera que você deseja criar pode guiá-lo: extrovertida ou sóbria, e assim por diante (UNGER, 2007:109).

15 3.7.2 Esboços_O primeiro movimento prático é realizar desenhos, geralmente manuais, que traçam rapidamente as características elementare que o projeto pode ter. O modo, intensidade e variedade como esses esboços acontecem, obviamente variam de acordo com o designer e com o tipo de projeto. Mas é comum começar por poucas letras cujas formas desenca20 deiam a construção de todo o alfabeto, letras maiúsculas, minúsculas e, talvez alguns algarismos, que contenham as formas estruturais ou características morfológicas básicas que poderão ser replicadas nas outras letras. Excetuando casos muito específicos, letras de peso normal regular ou medium de letras romanas (em pé, upright, não inclinadas) são

25 tomadas como ponto de partida. Matthew Carter, quase sempre inicia seu trabalho esboçando as letras ' $h$, o' diretamente no computador, o que o faz com muito cuidado, já que qualquer decisão errada nesse momento será multiplicada nas outras letras. Em seguida, desenha ' $p$, d' pois incluem elementos das duas letras anteriores que geram um terceiro, o bojo e suas 3o conexões com a haste. Segundo relato de Carter:

[...] existem decisões absolutamente fundamentais que você deve tomar nas formas destas letras que controlam o desenho de muitas outras letras da fonte. Em outras palavras, há informaçōes nesses poucos caracteres com as quais você pode extrapolar então, usá-las e reutilizá-las para formar outras letras do sistema (HOFFMAN, 1999:118) 
O 'v' é a próxima letra por envolver diagonais. Deve-se trabalhar um conjunto de seis ou sete letras até ter segurança em seguir adiant e começar a testar combinações como 'ac, ab, an, ao' e assim por diante. Sempre realizando provas impressas para manter e aferir a coerência formal do conjunto. Nas maiúsculas, além do 'H, O' o 'R' é uma letra importante porque engloba três estruturas básicas: haste vertical, haste diagonal e curvas. (WILKINSON, 2005:56)

Segundo o designer de tipos José Scaglione (2012), o método mais popular e regularmente empregado, apesar de ainda insuficiente, é começar pelas letras 'n, o', minúsculas, pois a partir de suas formas já é possível visualizar a cor tipográfica, proporções horizontais, contraste e eixo de modulação. O mesmo procedimento é adotado pelo designer Adrian Frutiger, com prioridade para a letra 'o'. Scaglioni ainda lembra que em quaisquer sistemas de escrita, muitas letras do alfabeto podem ser reunidas em grupos de similaridades formais cujas formas derivam de algumas poucas e que, sejam quais forem as letras desenhadas, já devem conter seus respectivos espaçamentos (HENESTROSA, MESEGUER e SCAGLIONE 2012:59). Outros caracteres esteticamente expressivos e designados como o "DNA" da tipografia como os 'a, g, Q' podem ser os protagonistas na formulação inicial do design, seguidos dos caracteres mais básicos.

Para o designer de tipos Jean F. Porchez (2014), após o questionamento do briefing e a verificação das possiviveis abordagens para atendê-lo, alguns caracteres básicos devem ser desenvolvidos e as minúsculas representam um estágio crítico. No caso de uma tipografia que deve dar apoio a uma identidade visual, esses caracteres são aqueles presentes no logotipo da marca. Para os projetos menos dependentes do logotipo, o designer contraria o processo mais aceito de começar pela dupla ' $n$, o'. Para ele, a forma da letra 'o' não é uma premissa, representando uma síntese das outras formas, e é a última a ser desenhada. O 'o' é impregnado pelo sentido que todas as curvas têm, e não o contrário. Curiosamente, inicia os desenhos com a letra ' $i$ ' para determinar o peso e serifas. Depois segue para o 'n' e 'p', e, na sequência, os 'a, e, f, g, t' que possuem as formas básica para todo o resto. Para as maiúsculas, apesar de não serem caracteres de muita personalidade, o 'H' e 'I' são os primeiros. A partir desses, definemse o peso e proporções em relação às minúsculas. O estilo das maiúsculas é delineado pelos 'E, G, R' que resolvem praticamente todas as situações de remates curvos, verticais, horizontais e diagonais (PORCHEZ, 2014:86). o1 As letras ou palavras básicas mais comuns, que servem de referência para a proposição inicial do design tipográfico, são as seguintes:

n, o- H, O: o conjunto mais elementar contém hastes verticais e horizontais, curvas completas e curva com reta (n); definem o peso (regular, mais leve ou mais pesada), as proporções (mais condensada ou mais expandida), o contraste (modulação entre traços grossos e finos), o eixo das curvas fechadas (inclinado, vertical ou ausente) o centro óptico (barra mediana do H). Normalmente, esse é apenas o estágio mais inicial, seguindo imediatamente para esquemas mais amplos;

n, o, v, + a - H, O, V: correspondência com as formas geométricas mais básicas: verticais, curvas, diagonais; define o peso, proporções,

contraste e centro óptico (H); o 'a' é acrescentado pela carga expressiva que atribui ao alfabeto; (HENESTROSA, MESEGUER e SCAGLIONE, 2012:70);

a, b, o, s - H, A, B, O, S: além do que foi citado no esquema anterior, adicionam-se a definição da altura-de-x (minúscula) e das ascendentes e descendentes, os bojos de 'B, b' e a complexidade da postura e fluidez das espinhas dos 'S, s'; esse conjunto já permite explorar o ritmo de palavras que simulam, por exemplo, o português: "sob os nabos na banana o osso ano sabana as nossos babosas aos sons no asnona o osso ano banana a abana os nossos bonos..."

dhesion - ADHESION: além do citado nos esquemas anteriores inclui outra letra complexa como o 'e' e o pingo do 'i'; por ser uma palavra completa, permite controlar o ritmo das formas e contraformas e avaliar o espaçamento dos caracteres encadeados em uma palavra:

Handgloves - HANDGLOVES: igual aos esquemas anteriores, agrega outros caracteres-chave: 'G, V, g, v";

hamburgefontsiv - HAMBQGURKS: igual aos esquemas anteriores, acrescenta outros caracteres importantes para a personalidade do alfabeto como os ' $\mathrm{M}, \mathrm{R}, \mathrm{K}, \mathrm{Q}, \mathrm{f}, \mathrm{t}$ ' 
Outros caracteres relevantes para o idioma principal e sinais não alfabéticos podem ser incorporados aos esquemas por conterem estruturas importantes para a personalidade da fonte na conjuntura da identidade visual, como os algarismos '2, 3, 5, 8' e sinais de pontuação e marcação como os '?, \&, *, vírgula'.

Em linhas gerais, após esta etapa, a qual inclui estudos de pesos outras variações, seguem-se as etapas de digitalização completa dos caracteres, ajustes métricos de espaçamento e procedimentos técnicos de ajustes finais, como demonstrados nos fluxos de desenvolvimento apresentados a seguir. Em todas as etapas, desde as primeiras letras que são digitalizadas no computador, provas impressas são consideradas fundamentais para avaliações de design, equilíbrio de formas e contraformas e, nos estágios mais finais, avaliações de funcionalidade e rendimento. Gerard Unger revelou durante suas aulas que sempre trabalha com uma impressora laser posicionada aos seus pés, imprimindo uma prova a cada passo importante no desenho de uma letra. No mesmo sentido, Matthew Carter relatou em entrevista aquilo que sempre aconselha aos seus alunos:

A única razão pela qual você trabalha em um computador é porque você não pode trabalhar diretamente em uma impressora. 0 computador apenas está lá para controlar a impressora. A verdadeira ferramenta é a impressora com 600 dpi's [...] Você precisa pensar por meio da impressora, não pelo computador (HOFFMAN, 1999:89 tradução minha $a^{41}$.

Esse procedimento, comum entre os designers mais experientes, demonstra uma prática que remonta aos primórdios da confecção de tipos móveis quando o tipógrafo, ao entalhar os punções de metal que gerariam as matrizes para a produção dos tipos de chumbo, realizava constantemente provas impressas passando os tipos sobre a fumaça negra de uma vela e imprimindo-os manualmente sobre um cartão procedimento conhecido como smoke proofs (SMEIJERS, 1996:98).

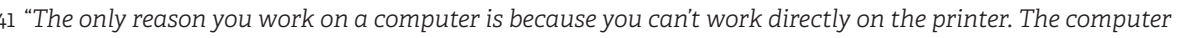
is only there to drive the printer. The real tool is the printer with 600 dots to the inch, (that beautiful printer sitting up there on the table is what you are really working with. You've got to think through the printer, no through the computer" "(HOFFMAN, 1999::99).
O momento seguinte compreende a apresentação das opções para cliente. As ideias são selecionadas e reduzidas às mais essenciais para corresponder ao briefing. Segundo o designer de tipos Jean F. Porchez

- as discussões sobre o projeto apresentado passam por questões mais genéricas e conceituais, não se atendo a detalhes específicos, ou seja, "ou o cliente aprova o design ou o rejeita" (PORCHEZ, 2014: 84). Nos estágios mais avançados do projeto, é raro o cliente rejeitar um ou outro caractere pois a atenção está voltada para a totalidade do design.

3.7.3 Fluxo do desenvolvimento de projeto (workflow)__ o conteúdo do briefing permite ao designer delinear o escopo ampliado que 0 projeto deve contemplar, procedendo, então, às questões preliminares citadas anteriormente. Independentemente do porte da type foundry ou

20 da envergadura do projeto, a aplicação de uma metodologia sistematizada é um fator crucial para transformar uma ideia abstrata em uma fonte digital consistente, pois organiza a administração de todas as etapas necessárias para o trabalho, previne a redundância de operações, evita erros e sistematiza as decisões de design.

Observados como exemplos, os procedimentos das type foundries Dalton Maag ${ }^{42}$, Inglaterra, TypeTogether (HENESTROSA, MESEGUER SCAGLione, 2012:60), República Tcheca, e a DooType ${ }^{43}$, Brasil, refletem o fluxo do desenvolvimento de fontes customizadas ou que obedecem a algum propósito de uso específico. Nas três empresas, de portes 30 diferentes, nota-se alguma coincidência na divisão e conteúdos das etapas, com pequenas variações e diferentes terminologias Enquanto as duas primeiras organizam o fluxo de desenvolvimento em quatro etapas, a última se concentra nas três primeiras etapas, encaminhando a outros profissionais serviços muito especializados:

42 Informaç̧oes pessoais obtidas em entrevista por Hangout, concedida em II de Dezembro de 20.4 43 Informaçōes pessoais obtidas em entrevista por Skype, concedida em 24 de Dezembro de 2014. 


\section{DALTON MAAG 44}

a. Idealização (Ideation)

b. Conceitualização do Design (Design Concept)

c. Refinamento do Conceito (Concept Refinement)

d. Execução (Execution)

Fontes customizadas: BMW, Toyota, Vodafone, Nokia Pure Tesco, Boticário, Intel, Olimpíadas Rio 2016

\section{TYPETOGETHER 45}

a. Etapa Projetual (Projectual)

b. Etapa de Design (Diseño)

c. Etapa de Produção (Producción)

d. Etapa de Pós-Produção (Posproducción)

Fontes customizadas: Adelle e Adelle Sans, para o Clarín (2014), Abril para La Voz de Almería (2013), Bree Perú (2011), Bodoni Stencil para a Levi's (2012).

\section{DOOTYPE ${ }^{46}$}

. Caminhos de Design (Pré-Projeto)

b. Design Completo

c. Revisão Técnica

Fontes customizadas: Unimed Sans, Unimed Serif e

Unimed Slab (2013) e Veja Serif (2013).

3.7.3.1 Fluxo de trabalho da Dalton Maag_ O processo foi registrado em entrevista ${ }^{47}$ concedida pela equipe brasileira de desenvolvedores Fábio Haag e Fernando Caro, com base no projeto da Petrobras Sans (detalhado no capítulo $4,4.5$ ) e reflete um procedimento padronizado da Dalton Maag.

4 Dalton Maag fundada em 1991 Londres pelo tipógrafo suís Bruno Maag wwwddlton agcon COna tualmente com equipe de desiners no Bral the

45 TypeTogether fundada em 2006 . República Theca, pela designer Tcheca Veronika Burian e pelo ww.type-together.com.

DooType. fundada em 2008, Brasil, pelo designer brasileiro Edulison Wesster Coan. http://dootype.com.br. 47 Entrevista via internet (Hangout), concedida em 11 de Dezembro de 2014 (ANEXO II). ideias das características que a fonte pode ou deve ter. Tais ideias são testadas, inicialmente, em um número limitado de caracteres que podem variar de sete a nove. Exploram-se os conceitos deterempresa de comunicação e design, articulando formas e proporções que atendam os conceitos-chave e os atributos da marca. Esta fase pode gerar desde pouquíssimas opções até mais de 40, como foi verificado no caso da fonte Petrobras Sans (42 opções diferentes com poucos caracteres). O objetivo é testar as possibilidades ao máximo, internamente. Neste momento, uma revisão e seleção das ideias mais promissoras e adequadas reduz o número de opções para que o processo seja encaminhado com mais objetividade. Em um segundo momento, as opções selecio15 nadas seguem para uma nova triagem, que pode ser conduzida pelo escritório de design ou agência de publicidade responsáve ou pela própria direção da instituição contratante. O resultado desta seleção é expandido para mais alguns caracteres e geradas provas de volume de texto, ritmo e cor da mancha. É comum a agência/escritório solicitar versões de tais fontes para testes em layouts, assim como os designers dos tipos também solicitarem layouts para aplicar as ideias em ambiente contextualizado e verificar a pertinência das opções.

25 Conceituação do Design (Design Concept): aqui, as opções finalistas, que podem ser uma única, duas ou três, são ampliadas para um conjunto maior de caracteres, abrangendo maiúsculas e minúsculas, caracteres de pontuação e alguns algarismos. Todos os parâmetros formais da fonte são cobertos por esses caracteres: altura-de- $x$, tensão das curvas, espinhas (curvaturas sinuosas como no 's, g, 2'), remates, diagonais, bojos, conexões curva-haste, sinais diacríticos etc., que são testados em palavras em tamanho de título e em textos. Novos testes contextualizados em layouts, preferencialmente utilizando os modelos do novo projeto gráfico (quando houver). Nesta etapa, estudos de pesos são desenvolvidos e grande variedade de gradações pode ser elaborada utilizando pesos extremos (light e bold) para gerar pesos intermediários por interpolação. 
Refinamento do Design (Design Refinement): todo o trabalho gerado na etapa anterior é submetido à avalição dos responsáveis diretos pelo projeto, normalmente a própria direção de comunicação da instituição, podendo sugerir alterações em algum ponto do projeto. Esta etapa é decisiva para um alinhamento final de todos os conceitos do design da fonte, o que inclui o painel de pesos e itálicos, o conjunto de caracteres necessários, se a fonte precisará de atenção especia para o desempenho em telas e suporte para outros idiomas.

Execução (Execution): trata-se da implementação dos pontos formu- 10 lados pelas etapas anteriores, não ocorrendo mais nenhum ajuste ou redirecionamento de ordem conceitual ou estruturalda fonte. Executa-se, então, a fonte de fato para todo o mapa de caracteres incluindo os idiomas previstos. Esta etapa é reservada para todo o trabalho de engenharia das fontes, ou seja, ajustes e controles técnicos como o hinting, aplicado para todos os caracteres de cada versão e para diversos corpos de tamanho, a validação da fonte que compreende pequenos processos de engenharia que utilizam programas acessórios específicos (ferramentas proprietárias Dalton Maag) e editores avançados de edição de fontes para conferir a 20 funcionalidade da fonte em certos aplicativos gráficos, como na assinatura digital para o $\mathrm{MS}$ Office ${ }^{\circ}$, por exemplo.

3.7.3.2 Fluxo de trabalho da TypeTogether Este processo foi baseado no esquema de fluxo e ordem de trabalho para a produção da fonte Adelle em sua versão romana que, apesar de não ser exclusiva, foi projetada especialmente para uso editorial em jornais e revistas. Segundo José Scaglione, tarefas individuais para cada etapa variam de acordo com cada projeto, mas devem se desdobrar de forma subsequente para não ocorrerem sobreposições ou deslocamentos indesejáveis de tarefas (HENESTROSA, MESEGUER e SCAGLIONE, 2012:62).
Etapa Projetual: abrange a compreensão geral do projeto da fonte desde a conceituação do design da família tipográfica, de sua função e do planejamento necessário para sua produção e conclusão. Nesta etapa, iniciam-se os primeiros esboços que estudam as alternativas de design. Neste caso da fonte Adelle, as letras iniciais foram a, $\mathrm{d}$, e, n, o' pois, além dos elementares ' $\mathrm{n}$, o', contemplam formas importantes como ascendentes, altura-de-x e bojo (d) e caracteres expressivamente importantes $(\mathbf{a}, \mathbf{e})$ e indicam as primeiras letras do nome da fonte, o que é válido como teste visual.

tapa de Design: uma vez definido o design das estruturas básicas, realiza-se o desenho de outras letras para formar o núcleo do mapa de caracteres, aplicando as formas-chave para as letras do mesmo grupo formal. É nesta etapa que se desenvolve o maior trabalho do desenho criativo, projetando os caracteres maiúsculos e minúsculos, caracteres não alfabéticos, algarismos, diacríticos, signos monetários, pontuação, espaçamentos e o controle da fluidez de todas as linhas vetoriais. Definido esse conjunto de letras, pode-se então, projetar os pesos extremos, light e extra-bold, para ancorar as versões que servirão de base para interpolação de outros pesos.

tapa de Produção: a partir desse ponto, o trabalho se torna mais mecânico' e acelerado, isto é, o designer ocupa-se mais de tarefas operacionais do que criativas. Antes de proceder à geração de pesos intermediários, conjuntos de caracteres derivados como, versaletes, algarismos minúsculos (Old Style Figures) algarismos sobrescritos e subscritos, frações e outros são constituídos digitalmente e depois acertados. Após a totalização de todos os glifos ${ }^{48}$ que compõem fonte e suas definitivas aprovações, geram-se os pesos intermediários so por interpolação e outros projetados por extrapolação, que também necessitam de um significativo volume de revisões e correções.

48 Glifo: em tipografia digital é um termo usado em distinção a caractere. Éa representação gráfica de um caractere de uma fonte; por exemplo: a letra a' a' pode ter dois ou mais glifos para representá-la, ou os caracteres 'f' e' $"$ '" podem ter representados por um único glifo' 'fi' (sMEIJERS, 2003:62). 
Etapa de Pós-Produção: antes de a família tipográfica estar pronta e liberada para o uso, deve passar por uma sequência de processos ratificação de funcionalidade, especialmente necessário para famílias compostas de muitos estilos. Os valores de kerning das versões criadas também devem ser interpolados para otimizar a produção, confecção de cabeçalhos de arquivos ${ }^{49}$, revisão das funções open type e, quando necessário, programação de hinting.

3.7.3.3 Fluxo de trabalho da Doo Type__ O registro do fluxo de trabalho da type foundry brasileira foi realizado por entrevista ${ }^{50}$ concedida pelo designer de tipos Eduilson W. Coan. O relato demonstra o processo usado para a criação da família de fontes Unimed. Uma empresa de pequeno porte, a Doo Type, é basicamente centrada em seu designe e conduz a produção de fontes corporativas de forma semelhante às de grande porte, centralizando várias etapas e terceirizando procedimentos muito específicos. Diferentemente dos dois fluxos anteriores, esse está divido em três partes:

Pré-Projeto de Design: fase de exploração conceitual de caminhos possíveis para o desenho básico das letras, a partir de desenhos 20 manuais. O ponto inicial são letras romanas, geralmente 'a, g' por se tratarem de caracteres-chave que determinam expressão do alfabeto e os básicos 'n, o' para definir as proporções horizontais do conjunto, peso, contraste, eixo de modulação etc. Em seguida, outros caracteres são agregados para determinar outros parâmetros como 25 altura-de-x, ascendentes e descendentes. Vetorização do grupo de caracteres para testes de desempenho em corpos diferente, ritmo de espaçamento, funcionalidade em corpos pequenos. Provas impressas são produzidas constantemente para avaliação da qualidade do desenho. Correções em diversos níveis ocorrem nesta etapa antes de 3 serem submetidas à avaliação final.
Design Completo: uma vez aprovada, a versão é ampliada para todo o mapa de caracteres necessários, e novos ajustes e correções permeiam esta parte do processo. Se o projeto previr mais pesos, os extremos light e bold são desenhados manualmente ou gerados 05 digitalmente e corrigidos. Novas provas impressas avaliam a relação de pesos entre o light-regular-bold.

Revisão Técnica: definição final dos parâmetros métricos de espaçamento e kerning, revisão dos caracteres acentuados. Interpolação para geração de versões com pesos intermediários. Se a aplicação de hinting mais aprofundado for exigida, esse trabalho é executado por profissionais especializados terceirizados. Caso contrário, o hinting automático dos softwares de geração de fontes é empregado. Nesta última etapa, provas impressas para avaliação e correção de espaçamentos e kernings são intensificadas.

De acordo com o relato dos designers Fabio Haag e Fernado Caro da Dalton Maag (ANEXo II), toda a sequência de produção de uma fonte customizada é naturalmente marcada por um contato mais atento às 20 questões de marketing e das diretrizes da marca, que parte de um nível máximo desde o inicio do projeto e, gradualmente, segue um percurso de autonomia à medida que as instâncias de produção mais técnicas se aproximam. Quando o conceito do design é aprovado e aplicado a todo o conjunto de caracteres, os designers assumem que o corpo do projeto

25 está definido e este avança para as variações de estilo e design de caracteres de outros idiomas. As avaliações críticas do contratante, nesse momento, praticamente se encerram, ficando limitadas ao acompanhamento e observações pontuais.

O quadro apresentado na página seguinte, procura reunir e combinar so as principais etapas e itens processados para a elaboração de uma tipografia customizada, baseando-se nos três procedimentos relatados anteriormente. Nele, as etapas estão descritas em suas características básicas, seguidas pelo detalhamento dos itens trabalhados. A frequência e tipo de investigação utilizando provas impressas estão pontuadas em 35 cada etapa, assim como a sinalização da participação efetiva do cliente durante o processo. 


\begin{tabular}{|c|c|c|c|c|c|}
\hline ETAPA & 1. BRIEFING & 2. CONCEPÇÃO & 3. DESIGN & 4. PRODUÇÃO & 5.IMPL \\
\hline DESCRIÇĀO & $\begin{array}{l}\text { INSTRUÇŌES } \\
\text { CONCEITUAIS } \\
\text { PRELIMINARES }\end{array}$ & $\begin{array}{l}\text { DESENHOS } \\
\text { EXPLORATORIOS } \\
\text { DE OCCOEES DE } \\
\text { DESIGN }\end{array}$ & \begin{tabular}{|l|} 
APLICAÇĀO DO \\
DESINN A UM \\
CONJUNTO MAIOR \\
DE CARACTERES E \\
ESTUDOS DE PESOS
\end{tabular} & $\begin{array}{l}\text { DESIGN COMPLETO } \\
\text { DO MAPA DE } \\
\text { CARACTERES E } \\
\text { PARAMETRIZAÇĀO } \\
\text { MÉTRICA }\end{array}$ & \begin{tabular}{|l} 
REVISĀO \\
EEFETIV/ \\
FUNCION
\end{tabular} \\
\hline \multirow[t]{3}{*}{$\begin{array}{c}\text { PRINCIPAIS } \\
\text { ITENS } \\
\text { TRABALHADOS }\end{array}$} & $\begin{array}{l}\text { - Imputs } \\
\text { - Diretrizes } \\
\text { criativas } \\
\text { - Conceitos-chave, } \\
\text { - Características } \\
\text { expressivas; } \\
\text { - Características } \\
\text { técnicas; } \\
\text { - Previsão de } \\
\text { Custos. }\end{array}$ & 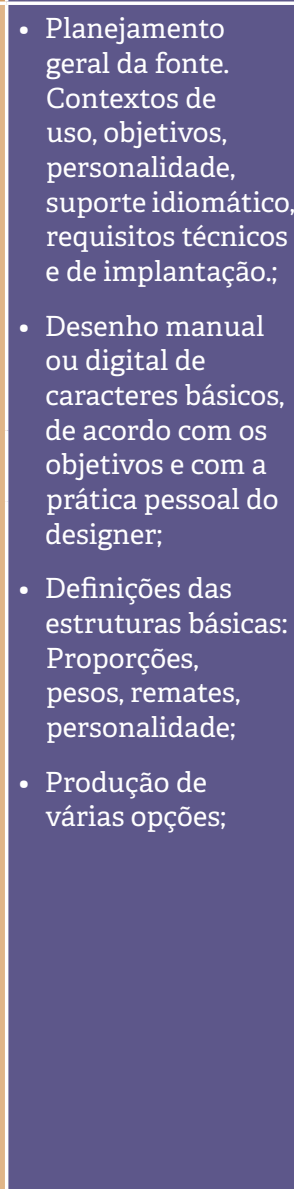 & \begin{tabular}{|l}
\multicolumn{1}{|c}{ DEFINIÇĀo } \\
- Desenho de \\
itálicos:; \\
- Design de \\
extremos de peso: \\
light - bold, ou \\
extra-bold - extra \\
light; \\
- Revisão/Correção \\
prévia de curvas \\
vetoriais.
\end{tabular} & $\begin{array}{l}\text { - Geracacão dos } \\
\text { caracteres } \\
\text { derivados como } \\
\text { versaletes, } \\
\text { algarismos } \\
\text { minúsculos } \\
\text { (old style figures) } \\
\text { e Tabulares, } \\
\text { algarismos } \\
\text { sobrescritos e } \\
\text { subscritos, fraçōes; } \\
\text { - Geração } \\
\text { de versōes } \\
\text { interpoladas e/ou } \\
\text { extrapoladas; } \\
\text { - Parâmetros } \\
\text { métricos, kerning; } \\
\text { - Extensão do } \\
\text { design final } \\
\text { para o mapa } \\
\text { de caracteres, } \\
\text { incluindo idiomas } \\
\text { do leste europeu } \\
\text { ou outro idioma } \\
\text { necessário; } \\
\text { - Programação de } \\
\text { open type features; }\end{array}$ &  \\
\hline & $\begin{array}{l}\text { PESQUISA/ } \\
\text { REFERÊNCIAS }\end{array}$ & $\begin{array}{c}\text { TESTES } \\
\text { IMPRESSOS }\end{array}$ & $\begin{array}{c}\text { TESTES } \\
\text { IMPRESSOS }\end{array}$ & $\begin{array}{c}\text { TESTES } \\
\text { IMPRESSOS }\end{array}$ & $\begin{array}{c}\text { TESTES } \\
\text { IMPRESSOS }\end{array}$ \\
\hline & $\begin{array}{l}\text { - Levantamento de } \\
\text { tipografias que } \\
\text { se aproximam do } \\
\text { design desejado; } \\
\text { - Pesquisa } \\
\text { de outras } \\
\text { referencias } \\
\text { visuais; }\end{array}$ & $\begin{array}{l}\text { - Avaliação da } \\
\text { qualidade do } \\
\text { design; } \\
\text { - Avaliação da } \\
\text { relação forma e } \\
\text { contraforma; } \\
\text { - Avaliação de ritmo } \\
\text { e cor tipográfica. }\end{array}$ & $\begin{array}{l}\text { - Avaliação de } \\
\text { conformidade do } \\
\text { design entre todos } \\
\text { os caracteres; } \\
\text { - Avaliação da } \\
\text { relação de pesos } \\
\text { light, regular e } \\
\text { bold; } \\
\text { - Testes de redução } \\
\text { e legibilidade. }\end{array}$ & $\begin{array}{l}\text { - Avaliação de } \\
\text { uniformidade de } \\
\text { espacamamentos } \\
\text { entreletras e pares } \\
\text { de kerning; } \\
\text { - Avaliação de } \\
\text { mancha de } \\
\text { textos em corpos } \\
\text { pequenos. }\end{array}$ & $\begin{array}{l}\text { Testes gerais } \\
\text { no ambiente } \\
\text { corporativo. } \\
\text { - Testes da fonte } \\
\text { em telas de } \\
\text { dispositivos } \\
\text { eletrônicos. }\end{array}$ \\
\hline DO CLIENTE & 10000 & 0000 & 00000 & 00000 & 0000 \\
\hline
\end{tabular}

\section{ㄴ. FONTES PERSONALIZADAS EM SISTEMAS DE IDENTIDADE VISUAL}

Para conhecer alguns parâmetros pelos quais uma tipografia constrói um repertório expressivo alinhado à identidade visual, este capítulo descreve e analisa seis projetos tipográficos customizados, observando

perfil e histórico da instituição, os requisitos elaborados no briefing que definiu as diretrizes para o novo projeto tipográfico, o processo de desenvolvimento das fontes e as referências consideradas para o projeto, as características expressivas da fonte, uma análise sintética dos atributos formais dos caracteres e o impacto da nova tipografia no material gráfico 5 da comunicação da instituição.

O propósito principal destes estudos é conhecer a variedade de abordagens no processo de criação e de soluções para um problema em comum: dar forma tipográica a ideias e conceitos abstratos, atribuindo às formas traços de personalidade, resultando em um design tipográfico 2o exclusivo e original.

Os critérios para a escolhas das seis tipografias estudadas buscaram diversificar os propósitos e ambientes de uso das fontes, porém as premissas eram que as fontes fossem apropriadas para leitura em texto, títulos ou sinalização, ou seja, não tivessem características aparentes muito fortes

25 ou muito evidentes, algo típico nas tipografias decorativas, fantasia e manuscritas; e que desempenhassem um papel fundamental para determinar ou reforçar a identidade visual da instituição. Esses critérios também obedeceram a alguns parâmetros de ordem prática: os projetos deveriam ter sido realizados e efetivamente implantados a partir do anos 1990 por

30 type foundries internacionais e nacionais, e fosse possível consultar o histórico do projeto por meio de entrevistas, bibliografia, apresentações em congressos e/ou observações no local em que as fontes são usadas. As fontes são a Rijksmuseum, de 2012, para o Museu Nacional em Amsterdam; a Parisine, de 1996, para o sistema de transportes parisiense; a famí-

35 lia Guardian para o jornal inglês The Guardian; a Yale, de 2004, para a universidade de Yale; a Walker, de 1995, para o Walker Art Center; e a Petrobras Sans, de 2012, para a estatal petrolífera brasileira. 


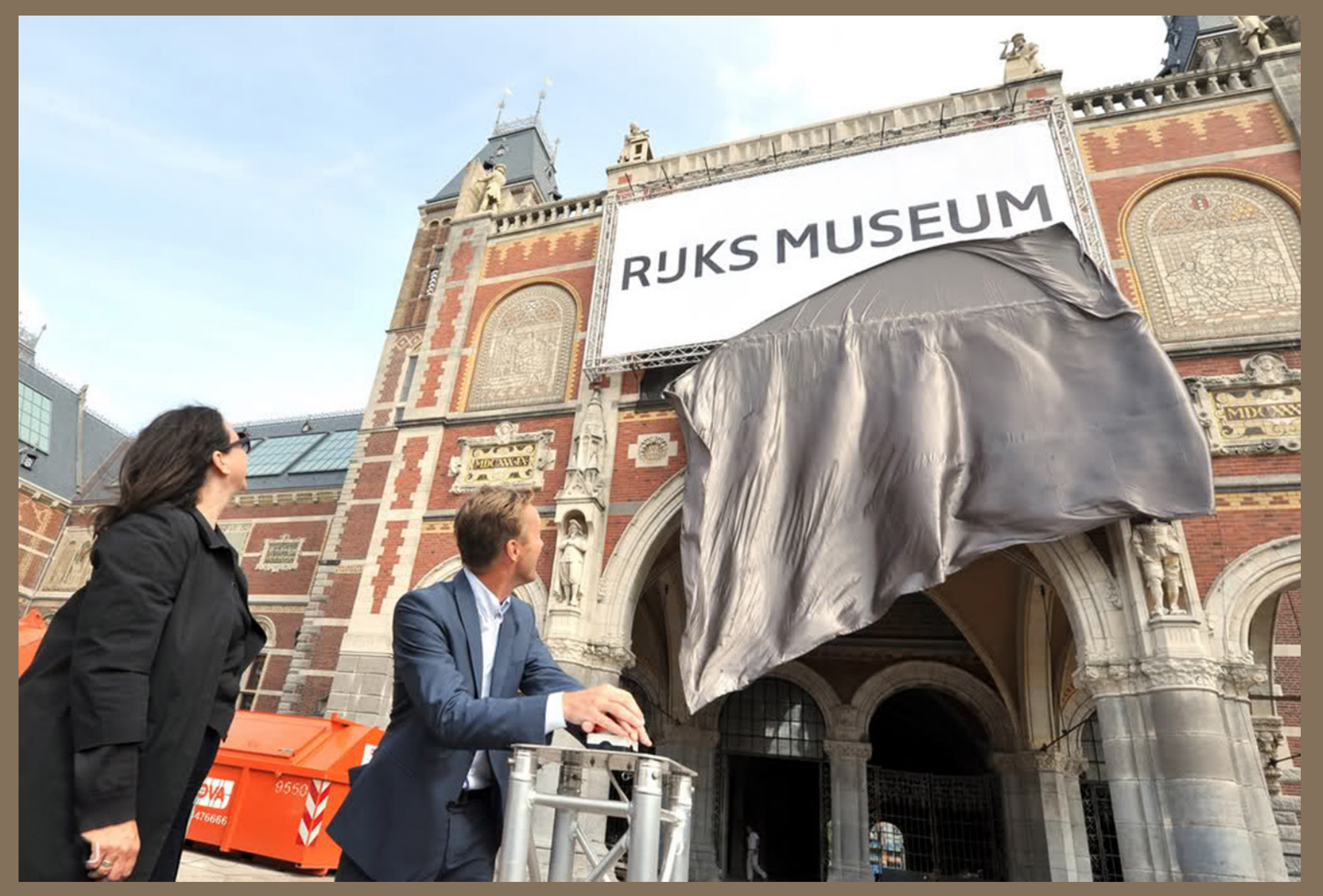

FIGURA 071_A designer Irma Boom acompanha a reinauguração do

diretor do museu Wim Pijbes. a1 4.1 RIJKSMUSEUM, 2012 Para celebrar a reabertura do principal museu nacional da Holanda, o Rijksmuseum (Museu do Estado), um novo projeto gráfico reformulou a identidade visual da instituição inalterada desde 1980 (FIGURA 071). O novo projeto não se ocupou somente em criar

05 outro novo padrão gráfico, mas buscou também incorporar e amplia aspectos da nacionalidade holandesa. As decisões para formar as bases dos elementos tipográficos do logotipo, os padrões cromáticos e, especialmente na família tipográfica Riksmuseum, consideraram ingredientes do gosto holandês e reforçaram questões idiomáticas na tipografia.

4.1.1 O Dutch Style: a identidade holandesa As particularidades históricas e geográficas e a população diminuta do país sempre puseram em cheque as questões culturais da Holanda, sob o risco de diluir suas peculiaridades através das fronteiras muito próximas de outros países.

15 Jan Middendorp (2004:9-10) lembra que apesar do eterno dilema entre o país estar inserido no contexto mundial, especialmente o europeu, e preservar as próprias características como nação, os holandeses conseguiram criar e impor seus valores, produzindo gerações de artistas e designers que influenciaram a produção cultural europeia. A preocupação em 20 compreender e proteger esse patrimônio intangível, que vai além do próprio idioma e da produção artística, é assunto de que muitas nações instintivamente se ocupam. $\mathrm{O}$ autor cita o designer de tipos alemão Erik Spiekermann, que considera a Holanda o país com a maior concentração relativa de designers de tipos no mundo e o que o impacto mundial da

25 produção vinda desses designers afeta continuamente a comunidade tipográfica global. Pragmatismo, individualismo e perfeccionismo são características que predominam no perfil desses profissionais que têm se destacado pela contribuição de novos padrões da emergente tecnologia tipográfica digital (MIDDENDORP, 2004:10). Para o tipógrafo Gerard Unger

30 (2007), um dos mais importantes designers de tipos atuantes do país, o design de uma tipografia reflete o caráter e a personalidade de quem a cria, refletindo sua educação e os valores da sociedade na qual viveu. No entanto, a tradição do design holandês de produzir tipos utilitários e funcionais também deu espaço para a criação de algumas "experiências

exóticas" como ZwartVet (1990) de Max Kisman Cocum (1998) de Evert Bloemsma e Twin Weird (2003) de Erik van Bokland e Just van Rossum (UNGER, 2007:104).

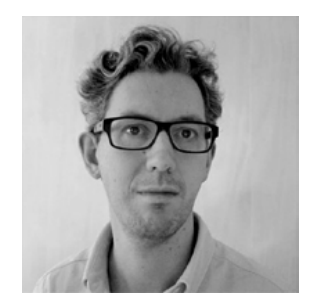

Paul van der Laan

Designer de tipos holandês nascid em 1972, trabalhou como designer gráfico e web designer na empresa $5 \mathrm{D}$, na The Enschedé Font Foundry (TEFF). Cursou a pós-graduacão em Tipografia Design de Tipos na Royal Academy of Art (KABK) em Den Haag (Haia), formando-se em 2000. No mesmo ano, fundou o estúdio tipográfico independente Type-Invaders com foco em tipografias customizadas. Ainda em no ano 200o, foi premiado com a medalha de prata na Competiçăo Internacional de Design de Tipos da inotype com a fonte Rezident. Desde 2003 e professor tutor na KABK no curso em que se graduou. Em 2008 fundou a type foundry Bold Monday juntamen com o designer de tipos Pieter van Rosmalen, concentrando a comercialização de suas fontes (MIDDENDORP, 2004:283-284) Suas principais fontes incluem Rezident (Linotype), , Lex (Type Invaders) Chalet Comprimé (House Industries) FF Kievit Pro (FontFont, em parceria com Mike Abbink, Resar (Yype Invaders e as customizadas para clientes como Universale Rijksmusum An, NBC 
Apesar do ecletismo cultural contemporâneo, em que um estilo deixa de ter um contorno nítido, há momentos em que certos padrões são reconhecíveis e circunscritos a um cenário comum. Na tentativa de relacionar uma característica física da paisagem local ao design e formas das letras, como suas terras baixas e céus frios, Middendorp (2004) descreve a tipografia que, para Gerard Unger representa a melhor tradição da tipografia holandesa:

Unger tem escrito que a tipografia reflete a horizontalidade da paisagem holandesa: 'Hollander é um dos meus projetos que refletem o inevitável

\section{Hollander Regular}

horizonte holandês. As partes planas das curvas são alongadas, a

suavidade resultante desses arcos combinam com as amplas serifa que colaboram para as letras se ligarem visualmente e criar palavras e linhas. (MIDDENDORP, 2004:168 - tradução minha $a^{50}$ ).

\section{ABCDEFGHIJKLMNO PQRSTUVWXYZÀÅÉ}

Em uma rápida análise, mais racional, podeconcluir que essa percepção é subjetiva demais, fugindo de qualquer parâmetro minimamente abcdefghijklmnOpq observar a influência que o extenso plano da as artes e ciências, moldando um espírito mais rstuvWXyzààé̂̃õ 1234567890 como exemplo, as suas fontes Swift e Demos, igualmente têm forte fluência horizontal, como nas partes curvas mais planas de 'a, c, e, $\mathbf{n}, \mathbf{s}$ ' que favorecem a leiturabilidade em textos mais longos. Hollander (FIGURA 072)

FIGURA 072_Amostras da fonte Hollander de Gerard Unger, 1983 inspirada no trabalho dos cortadores de tipos holandeses do séc. XVII como Christoffel van Dijcke Dirk Voskens. uma fonte que recupera as proporções e a atmosfera dos tipos holandeses do século xvi de tipógrafos de Utrecht, Leiden e Amsterdam como Hendrik van den Keere, Cristoffel van Dijk, Miklós (Nicholas) Kis e Dirk Voskens (MIDDENDORP, 2004:168; DIXON, 2012:G45), com seu eixo humanístico inclinado à esquerda, suas alturas-de-x altas, abertura amplas e aspecto robusto. $\mathrm{O}$ designer de tipos holandês Peter Bilak of my designs to reffect the inescapabble Dutch horizon. The horizontal part of the curves are stretched, the resultant gentle archés combining with the large serifs to assist the letters in joining visually to make words and lines (MIDDENDDRP, 2004:168).
(2004) sugere que observadores externos a determinada cultura podem identificar com mais clareza as características formais dos tipos pertinentes a ela. O designer lembra a afirmação de Gerard Unger em seu artigo Dutch landscape with letters:

O caráter nacional é 0 único componente necessário para o

reconhecimento do estilo do design tipográfico. Os principais elementos do estilo não são apenas os produtos do país, região ou cidade em que por acaso vive o designer, mas também são moldados pelas suas próprias qualidades pessoais e da época em que ele trabalha (BIL'AK, 2004 n. - tradução minha ${ }^{51}$.

4.1.2 A Identidade Visual do Rijksmuseum_ O Museu é formado por coleções de obras diretamente relacionadas à arte e cultura holandesa 5 contemplando 900 anos de história, especialmente por obras da Era Dourada Holandesa, período que abrange o século xviI, marcado por uma grande prosperidade política, econômica e cultural daquele país (HAUSER, 1982: 599-619). Fazem parte de seu acervo importantes obras de Rembrandt (Ronda Noturna), Johannes Vermeer (a Leiteira) e Frans Hals

20 (O Bebedor Alegre). Foi fundado na cidade de Haia, em 1800, e transferido oito anos depois, para a capital Amsterdam. Em 1885 passou a funcionar no edifício atual projetado pelo arquiteto holandês Pierre Cuypers. Tem uma arquitetura eclética que segue o estilo corrente na cidade velha e mistura elementos do estilo gótico e renascentista. No ano de 2000, foi

fechado para uma reestruturação completa. A reabertura em abril de 2013. foi acompanhada de uma reformulação de sua identidade visual conduzida pela designer Irma Boom, mais conhecida por seu trabalh no design editorial que já trabalhava para o museu havia dez anos e que foi responsável pelo redesenho do logotipo e por todas as publicações e pela sinalização interna e externa (RIJKSMUSEM, 2014, s.n.).

Ciente da importância dos três elementos fundamentais de uma Cidade a designer definiu, além da nova marca uma paleta cromática extraída da obra do pintor barroco Johannes Vermeer, Het Melkmeisje

51 "The national character is only one of the components needed for a recognizable style of type design.
The chief elements of style are the product not merely of the country, region or city in which the designer happens to live, they are also molded by his own personal qualities and the age in which he works" (BIIAK,2004, s....). 


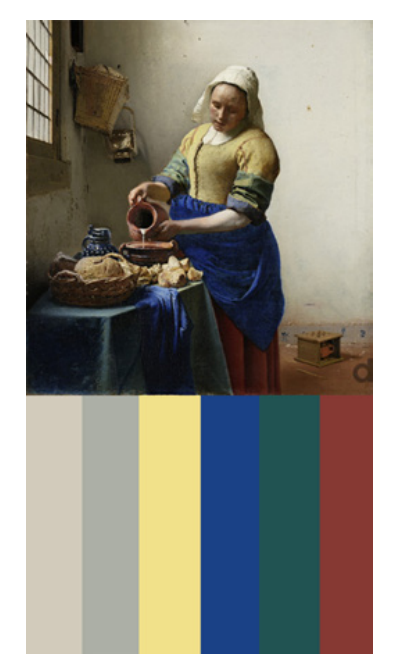

(1660), uma das obras que constituem o DNA do museu (FIGURA 073). $O$ conjunto de elementos da nova identidade foi completado por uma fonte tipográfica exclusiva, chamada Rijksmuseum, que está presente no logotipo de forma pura e privilegiada.

Ao redesenhar o logotipo, Boom foi direto ao ponto na reafirmação da identidade de seu país ao incluir um caractere típico do seu idioma. Para o detentor de um acervo de alta importância nacional e cuja visitação é majoritariamente composta por pessoas de outros países a designer partiu do pressuposto que “[...] o Rijksmuseum é um museu nacional com forte apelo internacional, o design deve ser limpo e forte para ancorar o museu no presente" (comunicação em palestra, ATyPI 2013, Amsterdam, 2013). O logotipo anterior foi criado em 1980 pelo Studio Dumbar em um período em que Irma Boom já trabalhava ali como estagiária. É uma composição que combina uma fonte sem serifa e uma serifada. A palavra 'RIJks' é grafada em News Gothic Condensed (Linotype ${ }^{\circ}$ ) e 'MUSEUM' está em negativo, ocupando uma tarja preta grafada em Baskerville maiúsculas, um tipo serifado transicional; palavra 'amsterdam' é grafada na mesma News Gothic Condensed em minúsculas (FIGURA 074). O conjunto reflete um design austero direto que se opunha ao experimentalismo típico dos anos 1980. A

\section{R I J K S MUSEU M

a $m$ s t e r d a m

RA 074_Logotipo do
museu criado pelo Studio Dumbar em 1980.

particularidade desse logotipo é o espelhamento da primeira letra ' $M$ ' e da segunda letra 'U' da palavra 'MUSEUM', invertendo a sequência do contraste das hastes. Essa inversão aparentemente não agrega nenhum significado específico e, de certo modo, cria um ruído visual que interfere na leiturabilidade da palavra.

Para acompanhar aquela identidade visual, foi empregada a tipografia DTL Documenta e DTL Documenta Sans, de autoria do designer tipográfico holandês Frank E. Blokland, palestrante sênior na Royal Academy of Arts em Den Haag (Haia) desde 1987 e professor na Plantin Society, Antuérpia, desde 1995. Blokland dirige a The Dutch Type Library, uma type foundry dedicada à produção e distribuição de fontes digitais de origem holandesa e flamenga (FIGURA 075). A fonte DTL Documenta foi iniciada em 1986 e disponibilizada como fonte Post 05 Script em 1993, sob a intensão de ser forte, contemporânea e reconhecível em qualquer situação de uso, de textos à sinalização, um design reconhecido em seus requisitos como uma fonte de texto robusta e aberta. Segue a tradição tipográfica renascentista holandesa, com altura-de-x alta, tem um contraste médio-forte e serifas assimétricas que revelam o traçado caligráfico. Apesar de usada por muitos anos como a fonte corporativa do museu, também era usada por outras instituições por se tratar de uma fonte comercializada no catálogo da DTL (DUTCH TYPE LIBRAY, 2014, s.n.).

\section{RIKS MUSEUM RUKS MUSEUM}

25 4.1.3 O novo logotipo A opção para o logotipo desenhada por Irma Boom em 2012, primeiramente, elimina qualquer elemento além da palavra. Não há símbolos, linhas ou planos de cor como retângulos ou círculos (FIGURA 076), portanto a tipografia desempenha um papel de extrema importância. Seguindo as ideias sustentadas por seu

compatriota e designer de tipos Gerrit Noordzij, para quem a palavra é a unidade e a condição para aquilo que chamamos de leitura (NOORDZIJ, 2013:47), a palavra em sua expressão mais direta e equilibrada ganha força máxima na nova marca - a palavra é uma imagem. O logotipo apresenta apenas a palavra 'RIJKS MUSEUM' grafada em letras pretas maiúsculas sobre fundo branco, em sua versão preferencial. Um ponto de discórdia entre a designer e os responsáveis pelo projeto no museu recaiu sobre a separação da palavra RIJKS (Estado) da palavra MUSEum (Museu), cuja
FIGURA 076_Logotipo criado por Irma Boom em 2012, na versão em psitivo e em negativo, utiliza a fonte de Paul van der Laan e ressalta o

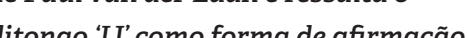
identidade holandesa. 
FIGURA 077_O ditongo 'IJ'em sua forma espaçada normal e sua forma ligada, caractere tipico do idioma holandess. A ligatura fica ais perculiar nas maiúsculas, enquanto as minusculas são apenas espaçadas mais apertadas. grafia correta é considerada sem o espaço e há uma forte vigilância a respeito disso no meio acadêmico local. Na verdade, trata-se de uma referência inserida por Boom, pois o museu é localmente conhecido apenas por Rijks. Como explica a própria designer em entrevista a Gabrielle Kennedy: “Eu nunca antecipei essa reação. Imaginei que todos os comentários seriam sobre o 'IJ'. [...] É um logotipo. Sou uma designer e tenho liberdade artística para interpretar essas coisas... é simplesmente uma imagem" (KENNEDY, 2012, s.n. - tradução minha ${ }^{52}$ ).

Segundo relatou Boom na palestra apresentada no congresso da AtypI de 2013, em Amsterdam5 ${ }^{53}$ esse espaço entre as duas palavras também seria útil para compor submarcas como RIJKS COLLECTIVE, RIJKS EVENT, RIJKS OPENING, e assim por diante. Por se tratar de uma instituição muito tradicional, mas que se mantém atenta aos rumos da arte contemporânea ao agregar algumas peças icônicas do século XX, as opções tipográficas deveriam cumprir funções básicas de sinalização em vários tamanhos e, acima de tudo, serem clássicas, não muito avant garde, mas, ainda assim, bem desenhadas e com espírito moderno. Essa abordagem foi influenciada pela experiência do novo design realizado pelo museu Stedelijk, especializado em arte moderna, cuja identidade visual de 2012 é arrojada e também alicerçada na tipografia.


O foco do logotipo Rijksmuseum recai sobre a grafia do ditongo IJ'54 que fortalece o caráter holandês ao mesmo tempo em que preserva uma particularidade da tipografia holandesa. Apesar de formado por uma vogal de fato e uma consoante, é considerado um ditongo pelo som

2 "I never anticipated this reaction," Boom adds. "I thought all the talk would be about the IJ". (...)

"It is a logol" Boom asserts. "I am a designer and I have artistic freedom to interpret these things.

it is simply an image." (KENNEDY, 2012).

33 Disponivel em http://www.atypi.org/type-typography/the-new-riiksmuseum-identity-and-typeface family-1. Acesso em: 04jan. 2015

54 IJ: em holandês, a combinação de "î" com "i" constitui uma vogal, que soa mais ou menos como um 'ei' ij Máquinas de escrever antigas tinham uma tecla diferente para a letra IJ. Hoje em dia, digitam-se as duas letras separadamente, (I' depois 'J'). http://www.dutchgrammar.com do fonema ( $\varepsilon \boldsymbol{i}$ ou $\boldsymbol{e} i$ ) e por se tratar de uma pronúncia alongada do 'i pode ser grafado separadamente ou formando uma ligatura: no caso de maiúsculas, o 'I' é reduzido em sua altura ocupando o espaço deixado pela forma aberta do 'J', logo acima de seu gancho (FIGURA 077), nas

05 minúsculas, a ligatura pode ocorrer por um terminal curvo do 'i' ligado ao 'j' (FIGURA 078). Trata-se de um caractere típico holandês e remete imediatamente a essa cultura. Foi, portanto, um ponto indiscutível para designer na composição do logotipo a incorporação do caractere em sua forma ligada. Contudo, não deixa de lado a preocupação com a pronúncia

- desse ditongo por indivíduos de línguas nativas muito diferentes, que, por outro lado, é uma vantagem: ao se deparar com a grafia, surge a curiosidade em compreendê-la e tentar pronunciá-la corretamente, chamando a atenção para uma singularidade nacional. Boom observou que antes de chegar ao resultado final, algumas ideias passaram por sublinhar a primeira palavra e substituir o ditongo por imagens que remetiam ao universo figurativo turístico da cidade, do emblemático sinal X XX X5 a estrela da marca de cervejas Heineken até coroas, setas e corações (FIGURAS 079 e 080). Na verdade, eram especulações em torno



5 O símbolo xx x refére-se às trêse cruzes de Santo André, um pescador que viveu no século I ICC. e oi crucificado em uma cruz em forma de X. Remonta ao ano 1505 quando a cidade era povoada por pescadores, de modo que o brasão de armas foi estabelecido como o símbolo para a própria cidade também tremulou como bandeira em todos os navios registrados em Amsterdam.
FIGURA 080_Prova dos estudos feitos por Boom experimentando maneiras variadas para destacar

Bergeijk Bergeijk

FIGURA 078_Comparação ditongo sem ligatura e com ligatura, criando uma forma semelhante ao ' $y$ '.

RIJKS MUSEUM

RIJKS MUSEUM

RIJKS MUSEUM

RUKS MUSEUM

R'JKS MUSEUM na fonte DIN Miettlschriftm, para a ligadura 'IJ', na tentativa de cria uma imagem coesa da palavra.
FIGURA 079_Prova com estudos, 
de uma marca que poderia assumir variações, conforme as situações de uso e foram apenas estudos para testar as possibilidades de trabalhar com a ausência das duas letras. Muitas tentativas de configuração desse caractere foram realizadas pela designer. A proporção exata entre os dois caracteres deveria ser alcançada para criar equilíbrio com as outras letras e ao mesmo tempo criar um foco de atenção.

4.1.4 A tipografia Rijksmuseum__ $O$ planejamento para a fonte tipográfica que acompanharia a identidade visual e de importância vital no sistema recebeu o mesmo cuidado que foi dado às questões de identidade, assim, um designer de tipos holandês deveria ser encarregado da tarefa. O designer Paul van der Laan da type foundry holandesa Bold Monday foi convidado por Irma Boom, em 2011, para executar o projeto tipográfico. Diga-se vital porque toda a identidade do museu está fortemente fundada na palavra e no texto, desde o novo logotipo, em toda a sinalização até nas pequenas etiquetas que identificam todas as obras do Museu.

Nos primeiros esboços que Boom realizou a fonte selecionada foi a DIN Mittelschrift (FIGURA 081). A escolha já apontava a direção que a tipografia deveria tomar: hastes sem contraste (ou mínimo), proporções mais retangulares e topo das curvas mais plano, suavemente condensada e altura-de-x alta. Mas a DIN é uma fonte originalmente não holandesa portanto não correspondia à questão fundamental da identidade nacional que deveria estar consistentemente envolvida em todos os aspectos da comunicação.

Com a chegada de van der Laan ao projeto, a opção de base passou a ser uma fonte já existente, Panno Text, de autoria dele e do designer de tipos Pieter van Rosmalen, de 2008-2010. Essa versão é uma adaptação da Panno Sign, uma fonte clara e robusta criada para romanizar os nomes na sinalização de ruas da Coreia do Sul. Sua característica condensada veio da necessidade de economizar espaço disputado com outros textos em coreano e chinês, exigindo ainda contraformas abertas e legíveis. A altura-de-x é muito alta, favorecendo as minúsculas, as quinas das hastes são arredondadas e o contraste é muito baixo, tornando-a robusta e adequada à sinalização. Panno Text (FIGURA 082), como uma extensão da versão Sign, foi optimizada para textos mais longos. O contraste foi ligeiramente aumentado, o espaçamento e contraformas totalmente
Oväder slog till mot hårdrockfestival
29 hours is a year on OGLE-TR-56b

duży nag tówek

papa arriva al don orione

Mann beißt Hund

\section{Two One-Legged Inmates Skip Jail}

inacreditável

Iljuni salvaw Bahar

"La methode est dé

penguin arrested while peeing

Ciudad Juárez $\rightarrow$ Malmö $\rightarrow$ Santa Domingo

Den Haag 23

Nuenen - Eindhoven - Jipsingboermussel

Hamburg 506

Zuidoostbeemster $•$ Nijmegen • Groningen

Boquerón 72 ע

såne - Maastricht - Kĩesomyslovẽ - Huy

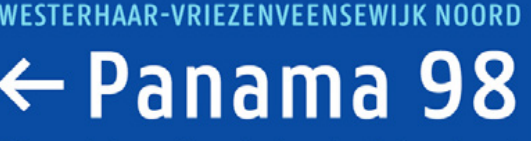

FIGURA 082_Amostras da fonte Panno Text (à esquerda) e da Panno Sign (à direita), de Pietr van Rosmalen 2008-2010, da type foundry Bold Monday, que serviu de base para

redimensionados e as hastes têm quinas retas, tornando-a própria para usos editoriais e para identidades visuais. A família é composta por 12 estilos (do light ao bold, com itálicas); suporta 40 idiomas e apresenta OpenType Features como frações, ligaturas, caracteres alternativos e 20 numerais sobrescritos e subescritos (BOLD MONDAY, 2014, s.n.)

Segundo Boom e van der Laan expuseram na conferência AtypI 2013, as questões enfrentadas na criação do logotipo tiveram desdobramentos no design da fonte. Alguns caracteres não agradaram a designer que precisava manter a força expressiva do nome, especialmente a letra 'S

25 cuja espinha muito inclinada transparecia muita suavidade ou fraqueza, pois, juntamente com o ditongo 'IJ' o 'S', era um dos os pilares de força do logotipo. $\mathrm{O}$ ditongo 'IJ' igualmente apresentou problemas, pois se assemelhava demasiadamente à letra 'U' (FIGURA 083). A fonte Panno Text também era sutilmente mais estreita do

que Boom necessitava, uma premissa importante da nova identidade. O ditongo é uma questão de distinção para os holandeses. $O$ emprego da ligatura não é constante por dificultar a leitura das palavras por estrangeiros, sendo substituído pela grafia separada. A reafirmação dessa

5 característica era um ponto indiscutível e deveria ser tratado com clareza. O projeto evoluiu em definitivo para uma nova e exclusiva fonte. Curiosamente, as proporções

\section{RUKS MUSEUM}

FIGURA $083 \_$A tentativa de aplica a fonte Panno Text no logotipo criou um ruído visual na ligatura ' $J$ ' assemelhando-se à letra ' $U$ '. 


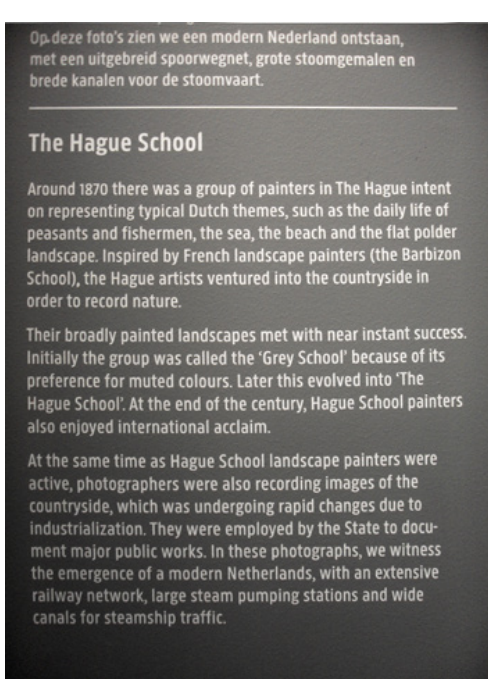

FIGURA 084_A necessidade de uma tipografia com condensą̧ão ideal sejustifica pela predominancia de muito reduzidos como nas etiquetas

de identificação das obras expostas.

das letras foram resultado de uma restrição imposta pela sinalização: as etiquetas que acompanham as obras preveem uma quantidade de informações muito variável, chegando a conter muitas linhas de texto em corpos 12-14 (FIGURA 084). A nova fonte precisava ser condensada 0 suficiente para atender a essa situação, assim como manter uma boa visualização em títulos maiores e na própria sinalização interna e externa. A preocupação com a leitura em ângulos muito abertos foi o limite para a definição da largura média dos caracteres.

Os aprimoramentos começaram pelo ' $\mathrm{J}$ ' do ditongo que recebeu um tratamento mais abrupto no final de seu gancho, menos curvo, permitindo uma assimetria e uma melhor legibilidade. A espinha do ' $\mathrm{S}$ recebeu curvas menos inclinadas, conferindo-lhe a força maior que Boom desejava. As conexões entre as curvas dos bojos e as hastes verticais foram suavizadas, tornando as contraformas completamente curvas (veja a letra 'b'). A letra 'g' foi redesenhada para o tipo de dois andares e as incisões de letras como 'a, b, n, u' receberam um corte diagonal incrementando a contraforma. A contraforma das letras com bojo é um ponto de grande diferenciação entre a Panno Text e a Rijksmuseum. Na Panno, as curva se conectam com as hastes retas de forma abrupta, criando uma quina na parte interna e, na Rijksmuseum, essa junção é mais suave, gerando uma contraforma mais ovalada (FIGURA 085).

\section{RUKS MUSEUM}

FIGURA 085_ No alto, revisão das formas e proporção das letras para - logotipo. Abaixo, a conparação Rijksmuseum Label e Text.



As proporções, peso e altura-de-x foram ajustadas para um bom desempenho em tamanhos grandes e para textos pequenos. Um detalhe agregado para proporcionar um reconhecimento mais particular foi um pequeno corte angular no topo das hastes ascendentes das minúsculas, 05 "para criar um ponto de ênfase e de diferenciação em relação à Panno", segundo van der Laan (FIGURA 086). A customização foi reforçada com programações OpenType para automatizar algumas operações automáticas de geração de textos, como a substituição do sinal 'hífen' pelo sinal 'travessãon', conjunto de algarismos alinhados com as minúsculase - versaletes (small caps) automáticos para a geração das etiquetas de obras.



Indagado a respeito do potencial identificador da fonte Rijksmuseum e se essa atendeu a algum pressuposto anterior, o designer comentou:

20 [...] o museu é uma instituição icônica e visitado mensalmente por milhares de pessoas que, além das obras, também mantém contato com a tipografia [...] a identidade está para ser construída a partir da exposição desse público com o design (Paul van der Laan, comunicação em palestra, Atypl 2013, Amsterdam, 2013)

Evidentemente, algumas questões nacionais já estão enraizadas no design de modo natural, visto que os holandeses tradicionalmente são preocupados com isso. Nesse caso, a motivação principal foi agregar um valor tipográfico à identidade de um dos museus mais importantes 30 daquele país na expectativa de que o reconhecimento desses valores ocorra pela via contrária, do espectador para a instituição. interna do museu, demonstra os letras 'u, m, a r' o corte diagonal no topo das ascendentes ' $l, t, d$ '. 
4.1.4.1 Principais aspectos anatômicos A família Rijksmuseum é uma tipografia sem serifa, com origem nos modelos neogrotescos de caráter industrial, para uso em títulos, textos curtos e sinalização. É composta por três versões: 1. A versão usada no logotipo (FIGURA 087) projetado apenas em letras maiúsculas e com proporções mais amplas; 2. Rijksmuseum Text, usada em impressos e materiais gerais de comunicação como folhetos, materiais de merchandising e na sinalização em alto relevo (FIGURA 088), formada por quatro estilos: Rijksmuseum Text normal, Rijksmuseum Text italic, Rijksmuseum Text bold e Rijksmuseum Text bold italic (FIGURA 089); e Rijksmuseum Label, uma versão mais condensada, apropriada ao grande volume de textos dos espaços exíguos das etiquetas e também usada nas sinalizações de tamanhos grandes e nas inscrições de baixo relevo nas paredes do saguão central, em quatro estilos: Rijksmuseum Label Medium, Rijksmuseum Label Medium Italic, Rijksmuseum Label Semi-Bold e Rijksmuseum Label Semi-Bold Italic (FIGURA 090).

\section{RIKS MUSEUM LOGOTYPE FONT ABCDEFGHIJKLMNO PQRSTUVWXIYZ 0123456789 \\ /[('\&.!?’)]। \\ da Bijksmostra do logotipo em sua versãoúnica.}

Rijksmuseum Normal ABCDEFGHIJKLMN OPQRSTUVWXIYZ abcdefghijkImnopqrs tuvwxyz Rijksmuseum Italic ABCDEFGHIJ KLMNOPQRSTUVWXIJYZ abcdefghijkImno pqrstuvwxyz Rijksmuseum Bold ABCDE FGHIJKLMNOPQRSTUVWXIYZ abcdefg hijkImnopqrstuvwxyz Rijksmuseum Bo IdItalic ABCDEFGHIJKLMNOPQRSTUVWX JYZ abcdefghijkImnopqrstuvwxyZ

FIGUPA 089 Amostra da família tipográfica Rijksmuseum Text em suas variaçốes de peso e itálicas.

Rijksmuseum Label Medium ABCDEFGHIJKL MNOPQRSTUVWXIJYZ abcdefghijkImnopqrstu vwxyz Rijksmuseum Label Medium Italic $A B C$ DEFGHIJKLMNOPQRSTUVWXIYY abcdefghijkI mnopqrstuvwxyz Rijksmuseum Label SemiB old ABCDEFGHIJKLMNOPQRSTUVWXUYZ abc defghijkImnopqrstuvwxyz Rijksmuseum La bel SemiBold Italic ABCDEFGHIJKLMNOPQR STUVWXIYZ abcdefghijkImnopqrstuvwXyZ
FIGURA 090_Amostra da família tipográfica Rijksmuseum Label em
suas variações de peso e itálicas. 


\section{ABCDEFGHIJKMN abcdefghijkimno}

FIGURA 091

Rijksmuseum Text Bold

destacada nas partes

mais importantes dos

caracteres chave.

Seguindo a estrutura descritiva proposta por Catherine Dixon (2008 2011), os atributos formais da Rijksmuseum Text são:

Construção contínua dos traços;

Formas curvas são mais redondas, levemente retangulares (como no 'o')

e as curvas abertas são francamente planas (como no 'a, c, s')

Hastes são verticais, paralelas retas com remates das quinas retos, posição da linha média (como no 'B, E, H') visualmente simétrica;

Proporção geral é semicondensada, com maiúsculas em proporções

regulares, altura-de-x alta e ascendentes mais altas que as maiúsculas;

Modelagem observa-se ausência de eixo inclinado, um contraste

(variação de espessura das hastes) mínimo com transição gradual;

Caracteres-chave:

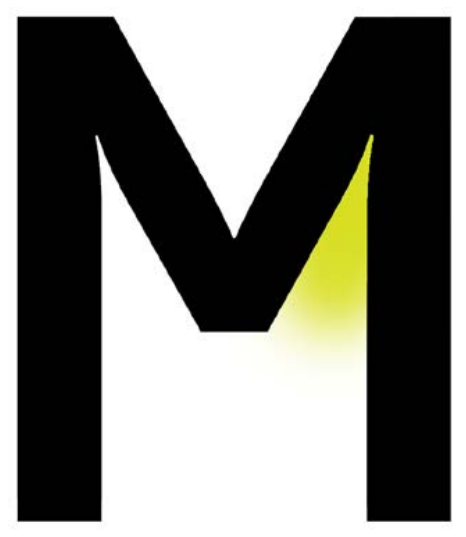

a, duplo andar com bojo circular nas romanas e um andar nas itálicas; e, com barra horizontal nas romanas e bojo curvo nas itálicas; g, com duplo andar e laço fechado nas romanas e um andar e gancho descendente aberto nas itálicas:

$\mathbf{b}, \mathbf{d}, \mathbf{h}, \mathbf{l}, \mathbf{k}, \mathbf{t}$, corte inclinado no topo esquerdo das ascendentes:

$\mathbf{k}, \mathbf{K}$, com conexão do braço e perna simples e quase tangencial;

G, com pescoço reto em quina, sem espora e barra curta e elevada;

$\mathbf{M}$, com vértice bastante elevado:

$\mathbf{N}, \mathbf{M}, \mathbf{V}, \mathbf{W}$, fendas (inktraps) na junção de hastes muito apertadas (FIGURA 092);

FIGURA 092_Detalhe da fenda para areas muito justas (viritha), prevenindo o acumulo de tinta na impressão.
Q, com cauda ondulada na horizontal e terminada para cima:

$\mathbf{R}$, perna reta e diagonal;

S, s, com ligeira inclinação para a direita.

\section{OPORSTUVWXIY pqrstuvwXyz \&'}

4.1.5 A família Rijksmuseum aplicada na identidade visual O museu ocupa um edifício histórico, em uma região que compartilha com outros importantes museus de Amsterdam como o Museu Van Gogh e o Stedelijk Museum, área frequentada por uma considerável quantidade de visitantes de todo o mundo que, obrigatoriamente, entram em contato com a identidade visual do Rijksmuseum. O que se observa é um planejamento gráfico essencialmente guiado pelo texto e, por consequência, pela tipografia. Nas áreas internas da entrada a sinalização é generosa com o tamanho das letras, permitindo um contato muito próximo com alguns detalhes da tipografia (FIGURA 20 093). Além do contato menos impactante, mas muito mais frequente e espalhado por cada seção do museu pontuado pelas etiquetas das obras, os itens de merchandising e souvenires (FIGURA 094) disponíveis nas lojas tratam de apresentar o logotipo do modo mais simples e direto, livre de qualquer outro elemento que possa desviar a atenção, a não ser para as letras. Na homepage do museu, o logotipo é ampliado ao máximo, sendo necessário rolar a imagem para vê-lo por inteiro. A tipografia Rijksmuseum é utilizada em todos os títulos, subtítulos, legendas e textos do site (FIGURA 095).
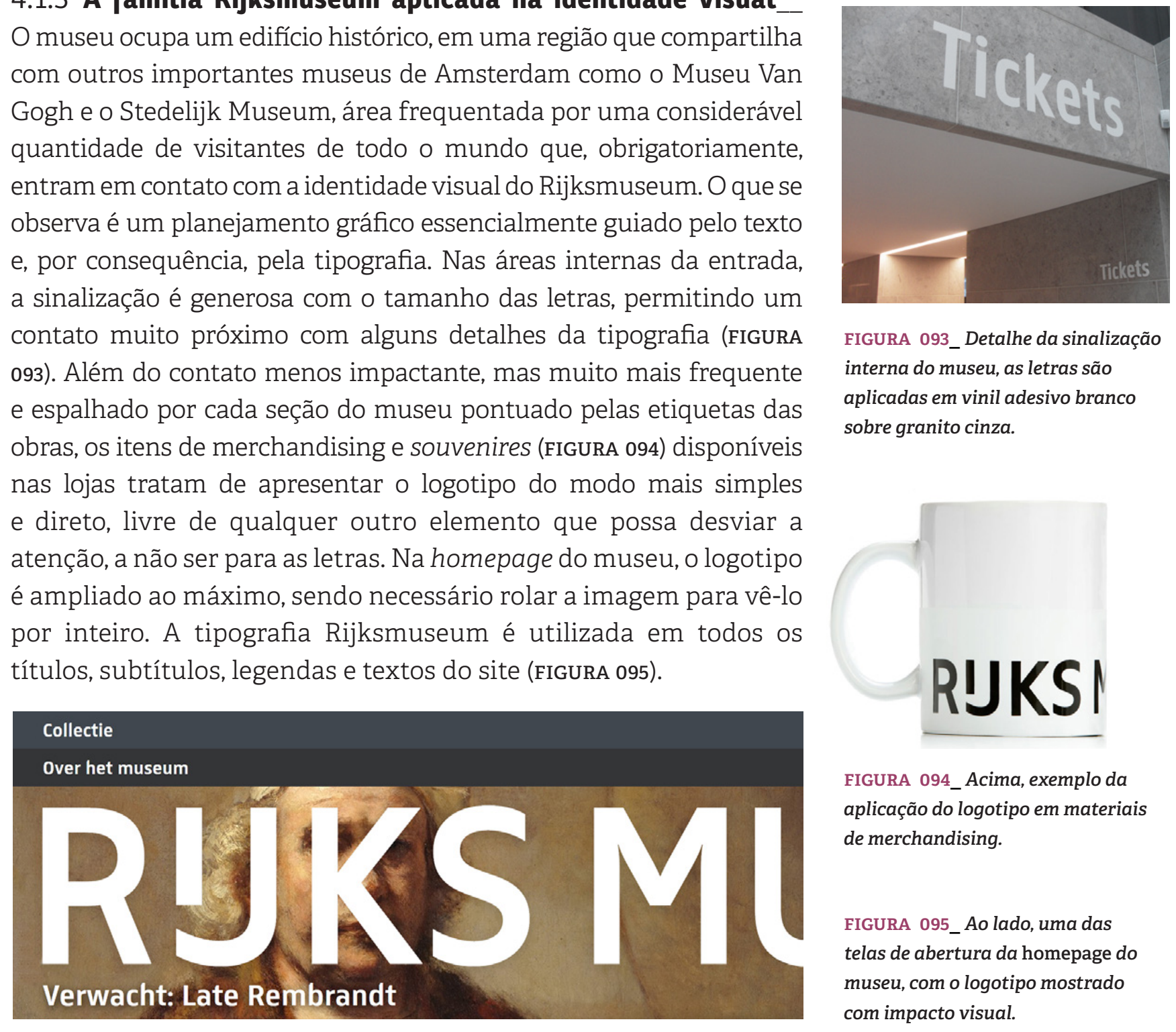

FIGURA 093_Detalhe da sinalização interna do museu, as letras são aplicadas em vinil adesivo branco sobre granito cinza.



FIGURA 094_Acima, exemplo da aplicação do logotipo em materiais de merchandising.

FIGURA 095_Aolado, uma das telas de abertura da homepage do museu, com o logotipo mostrado com impacto visual. 


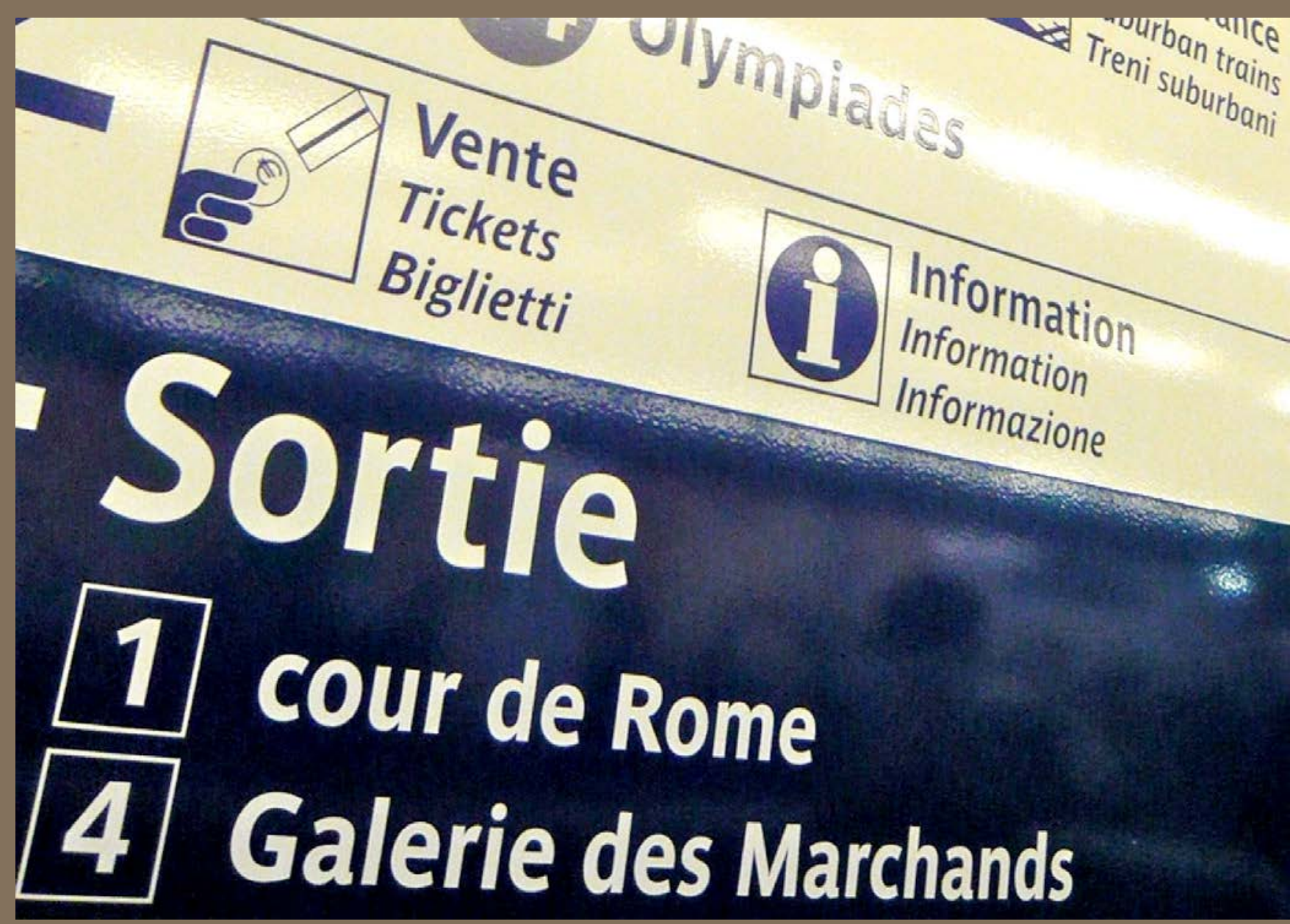

com a fonte Parisin
42 PARISINE, 1996 Da mesma maneira que o jornal parisiense Le Monde se sentiu incomodado por utilizar uma tipografia de caráter anglosaxão e preferiu desenvolver uma família própria, o sistema transportes público de Paris decidiu que era o momento de dar para a sua comunicação

textual um tom menos "suíço" e mais identificado com a cultura francesa (RAULT, 2014:14). Em 1995, a Régie Autonome des Transports Parisiens, a RATP ${ }^{56}$, contratou o designer francês de tipos Jean-François Porchez para criar uma tipografia corporativa que, a princípio, se resumiria a apenas redesenhar uma versão da fonte que o sistema já utilizava. Mas por força do ímpeto nacionalista e das referências mais "latinas" do designer (ZAPATERRA, 1999:33), o projeto se transformou em algo completamente novo e desvinculado da rigidez e austeridade dos tipos sem serifa usados desde os anos 1960

4.2.1 A ratp e a necessidade de uma única tipografia $O$ sistema de transportes da cidade de Paris no pós-guerra foi criado em 1948 partir da fusão de companhias de transporte privado que abrangiam os sistemas de onibus, trens, bondes e metrô (FIGURA 097). Desde então, instituição controla um sistema formado por 14 linhas de metrô, duas 20 linhas expressas regionais de trens (RER), seis linhas de bondes, uma rede com cerca de 350 linhas de onibus e outros serviços de mobilidade urbana como teleféricos e linhas de transportes diretos (RATP, 2015). No início da década de 1990, a instituição começou um processo de modernização dos equipamentos e instalações de suas redes, incluindo a uniformização de todo o sistema de sinalização e informação (RAULT, 2014:22).

Ao longo dos anos 1980, o tradicional uso de maiúsculas para grafar os textos parecia estar exaurido na questão de legibilidade, um fator que influenciou o projeto de Adrian Frutiger para a sinalização do aeroporto parisiense Roissy Charles de Gaule (1970-1975), em que o

o designer rejeitou o uso de letras sem serifas maiúsculas alongadas pela perda da boa legibilidade causada pela similaridade das formas centrais (contraformas) das letras (PORCHEZ, 2004 s.n.). Nesse projeto de Frutiger para o aeroporto, as minúsculas foram incorporadas com o objetivo de aprimorar a legibilidade. Na sinalização da RATP, a tipografia utilizad

56 A ratp possui participaçăo na construção e operaçăo da linha 4 do Metro paulistano. metrôde Par_sinalização interna do metrô de Paris com tipografia sem serifa, grotesca e semicondensada.
Cerca de 1950. 


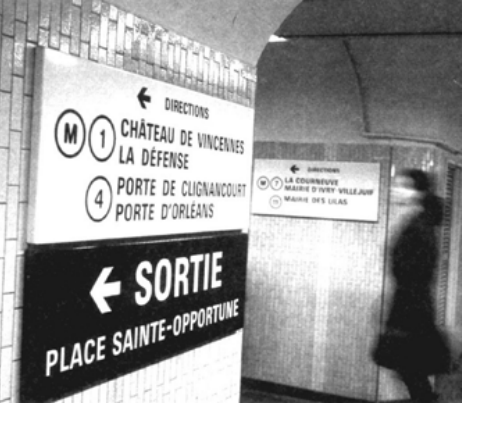

FIGURA 098_ Sinalização interna do metrô de Paris com a tipografia Univers, de A. Frutiger, adaptada ao

ALPHABET MÉTRO

ABCDEFGHIJKLMNOPOR

STUVWXYZ LA LT TT

Â É È Ê Ç Ü

.'-_-

1234567890 AOÛT 1973

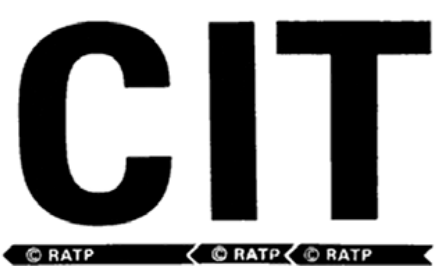

EIGURA 099_Amostra do alfabeto Métro de Adrian Frutiger, 1973. pelo sistema até 1995 estava diluída em ao menos quatro tipos de letras diferentes: um tipo sem serifa de Albert Boton (1970) composto apenas de maiúsculas e projetada para a sinalização do sistema de trens (RER) a Métro (1973) de Adrian Frutiger, também apenas em maiúsculas (FIGURA 098 e FIGURA 099) para uso na sinalização do metrô, a inglesa Gill Sans (1928/31), usada em peças gráficas de comunicação e a suíça Neue Helvetica, usada nos sitema de sinalização da rede de onibus. Essa diversidade pode ser explicada pela origem da companhia, formada por sistemas independentes com suas identidades individuais, e pela própria tradição das letras grotescas, sem serifa, herdadas do século XIX e com os letreiros em estilo Art Nouveau e Art Déco da virada para o século xx. Porchez lembra que quando Frutiger foi encarregado da Métro, ele havia ressaltado a importância da adequação do design da tipografia ao histórico da cidade:

É o charme especial do Metrô de Paris que sua estética não é carimbada com um estilo uniforme. Formas de expressão de cem anos, como os belos portais Art Nouveau estão, ainda presentes em muitos casos. Essa variedade deve ser preservada o melhor possível, como um enriquecimento do cenário. A união de elementos tipográficos em uma nova ordem harmoniosa era uma tarefa que exigiu um certo grau de restrição, algo natural para a criação de novas formas (PORCHEZ, 2004, s.n. - tradução minha57).

A RAPT opera um sistema de transporte urbano "multimodal", com possibilidades de interconexão entre diferentes modos de transporte, portanto, a linguagem gráfica precisava ser única para que o usuário compreendesse melhor suas opções de trânsito entre diferentes meios. Em 1994, a instituição iniciou um processo de reformulação e uniformização de toda a sua sinalização. Consequentemente, surgiu a necessidade de adotar uma tipografia única que, além de realizar esse papel de conexão visual, alcançasse melhores níveis de legibilidade e de rendimento do

"It is the special charm of the Paris Métro that its applied desthetics are not stamped with a uniform style. Forms of expression of the past hundred years, such as the beautiful Art Nouveau portals, are in many cases still present. This variety should be preserved as well as possible, as an enrichment of the scene. The joining together of typographical elements into a new harmonious order was a task requiring a certain degree of restraint so far as the creation of new forms was concerned" (PORCHEz, 2004, s.n.). texto (PORCHEz 2004 Sn). A deliberaç̃̃o inical da diretoria foi de que apenas uma tipografia que já estivesse sendo utilizada, deveria se adotada. Pela ampla disponibilidade nos sistemas de computadores da época, a Neue Helvetica foi a opção mais óbvia. David Rault (2014:24) cita o5 que aquilo que poderia ser uma vantagem, se verificou um problema. Por se tratar de um tipo já "massificado" pelo uso generalizado por décadas, a Neue Helvetica poderia ser ingenuamente confundida e substituida por outras opções muito semelhantes como, Arial ou Helvética, tipos disponíveis gratuitamente nos sistemas operacionais. Como o sistema de

comunicação é executado por muitos usuários e fornecedores de materia gráfico, a consistência tipográfica poderia novamente se perder. Somado a isso, Porchez (2004, s.n.) acrescenta que a grande variedade de opções de estilos da Neue Helvetica, prejudicava o sucesso da implementação do sistema de identidade visual, possibilitando pequenas variações que

5 afetaria negativamente um projeto de unificação da tipografia.

Os designers responsáveis pelo novo projeto gráfico identificaram que a Neue Helvetica é um tipo muito largo para algumas composições, um fator crítico em certos tipos de sinais com textos

zo ou palavras longas em pouco espaço (RAULT, 2014:24). O idioma francês, possui nomes de logradouros curtos como Nantes, e outros bem mais extensos como Chaussée d'Antin La Fayette, por exemplo (FIGURA 100). Como a fonte já era

usada nos sistema visual para a rede de onibus, uma alternativa foi solicitar para type foundries como Linotype $^{\oplus}$ e Agfa ${ }^{\oplus}$ uma versão única da fonte Neue Helvetica condensada em $10 \%$. Na verdade, a instituição planejava distribuir fonte para seus fornecedores o que violaria os direitos intelectuais de

o propriedade. Aliada a essa questão legal, a falta de contraste na identidade, proporcionada por uma fonte tão amplamente comercializada e usada, começou a direcionar todo o projeto para a criação de uma tipografia personalizada e exclusiva, o que traria, entre muitos benefícios a certeza da distribuição e uso de uma fonte de maneira invariável, generalizada, de acordo com a legislação e a custos mais viáveis.

Zapaterra (1999) cita que Porchez alegou que "a RATP precisava controlar as fontes utilizadas pelos subcontratados que trabalhavam 
para ela, afim de criar um estilo uniforme" (ZAPATERRA, 1999:32 — tradução minha ${ }^{58}$. Martine Turner diretora da Agfa Paris, mais preocupada com a demanda criativa do projeto do que com questões comerciais, chamou J.F. Porchez acreditando que a solução deveria vir de um designer nativo.

4.2.2 Parisine: de uma simples adaptaçãoà uma familia tipográfica original_Porchez começou a trabalhar em março de 1995 propondo uma versão alternativa genuína da Neue Helvética (RAULT, 2014:24). O conceito partiu das mesmas proporções da Helvetica, seguindo a condensação desejada, mas que preservasse ou até aumentasse a legibilidade, por meio de contraformas mais abertas e curvaturas mais amplas. Uma referência inevitável foi a tipografia desenvolvida por Frutiger para o aeroporto Roissy Charles de Gaule (ZAPATERRA, 1999:33), que se tornaria mais tarde a icônica Frutiger, cuja eficiência na legibilidade já havia sido testada. Repetindo a experiência que praticou no projeto para o jornal Le Monde, Porchez vetorizou algumas letras, compôs o nome de duas estações com letras brancas sobre fundo escuro, e as comparou com a Helvética. Como a fonte seria usada inicialmente para sinalização, testes de visualização foram realizados com provas impressas no tamanho A4, afixadas na parede e com luz reduzida para simular o ambiente interno 20 do metrô ou a noite em um ponto de onibus. O resultado positivo entusiasmou a equipe de designers e a fonte, batizada de Parisine, pode

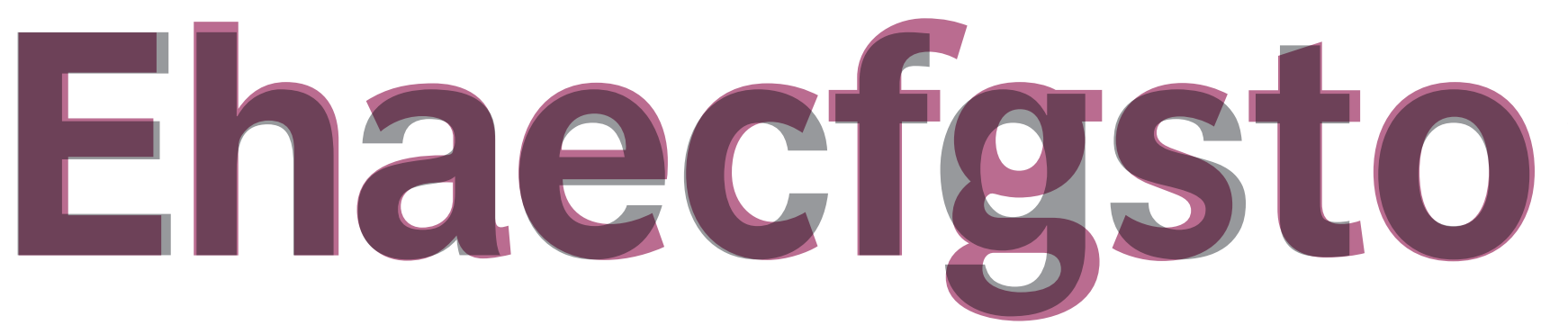

FIGURA 101_A Parisine Bold (rosa) comparada à Neue Helvetica 75 Bold condensada en $10 \%$ (cinza) mostra as di mais legivel e humanizada.

niciar, de fato, seu desenvolvimento (PORCHEZ, 2004, s.n.). Para alcançar os objetivos, os remates curvos de 'a, c, e, f, s, t' foram aplanados (FIGURA 101). abrindo o espaço branco das letras e realçados; o gancho do ' $\mathrm{f}$ ' o remate curvo do ' $t$ ' forma alongados para recuperar a legibilidade na proporção mais condensada; o contraste entre hastes verticais e horizontais foi incrementado: a altura-de-x cresceu e as ascendentes ficaram mais altas que as capitulares; e a letra ' $\mathrm{g}$ ' foi desenhada com dois andares, baseada no design de Edward Johnston para o metrô de Londres (1916), cuja forma única se distingue dos caracteres 'b, d, p, q' 05 que, por sua vez, também são sutilmente diferentes entre sí. Essas intervenções, aparentemente simples, seguem os princípios básicos da legibilidade que, segundo o tipógrafo britânico Eric Gill (GILL, 1988:43), os caracteres devem se diferenciar um dos outros assim como a proporção de preto e branco das letras (forma e contraforma), considerando que relação entre coerência formal das estruturas básicas e a diferenciação de caracteres demanda um equilíbrio muito delicado. Nesse sentido as aberturas e contraformas mais espaçosas foram importantes para recuperar as perdas com a condensação, especialmente no peso bold. O cuidadoso tratamento dado à parte superior das letras minúsculas 15 também está relacionado com a legibilidade. Pesquisadores como o oftalmologista Louis É. Javal, Gerrit W. Ovink (1938:76-78) e O. Messme (SPENCER, 1969:14) já haviam compreendido a importância das formas das ascendentes e do topo das letras para o reconhecimento dos caracteres e para a boa leitura de palavras. Essas três referências tipográficas, Neue 20 Helvetica, Frutiger e Gill Sans, contribuíram para a formação conceitual e estrutural da Parisine (FIGURA 102). Dessa última, veio a abordagem mais humanista para os traços, uma tentativa de unir a elegância dos tipos romanos com a solidez dos tipos sem serifa do início do século xx. Como o próprio designer definiria sua meta: “[...] eu criaria uma tipografia

25 que mesclaria a qualidade da Helvética condensada com a humanidade da Gill Sans!" (ZAPATERRA, 1999:33 - tradução minha $a^{59}$ ), numa busca pela boa postura e eficiência da primeira associada ao espírito mais amigável, curvas mais suaves e legibilidade da segunda.

Os pesos bold e bold italic foram os primeiros a serem desenhados, pois se adequavam melhor à sinalização (Ibid.:37). A versão bold se destina aos textos em francês, suas maiúsculas seguem as proporções das capitulares romanas e são ligeiramente mais largas e mais pesadas que as minúsculas, almejando uma melhor "imagem” da palavra. A versão bold italic é reservada para traduções e informações para estrangeiros, 59 "I told them that I woula create a typeface which mixed the quality of Helvetica condensed with the humanity of Gill Sans!' (ZAAATERRA, 1999:33).

\section{Parisine Parisine Parisine Parisine}

FIGURA 102_As três referência Neue Helvetica (1), Frutiger (2) Gill Sans (3). 


\section{aefno aefno}

FIGURA 103_Comparação entre caracteres da Parisine Regular e de design que contribuem para o ritmo cursivo da itálica.

normalmente em inglês. Para criar um aspecto mais cursivo, a bold italic foi desenhada um pouco mais estreita e mais leve que a bold romana. Diferentemente de uma simples inclinação das romanas, o que reduziria a distinção entre os dois estilos, a versão itálica segue os padrões tradicionais de independência formal entre romanas e itálicas, que pode ser observado nos caracteres 'a, e' e nas junções mais agressivas entre curvas e hastes. O problema do 'a', de um único andar, se parecer muito com o 'o', foi minimizado com um reforço no remate curvo inferior mais saliente (FIGURA 103). Nas itálicas clássicas, a letra 'f' recebe uma descendente curva para valorizar o ritmo cursivo em textos corridos. Porém, na Parisine Italic essa solução não ficaria adequada para os tamanhos maiores. A fonte também possui, além das ligaturas padronizadas (standard) que solucionam conflitos e sobreposições de partes das letras, outras ligaturas discricionais, aquelas criadas por motivação ornamental ou histórica, que não são usadas na sinalização e reservadas apenas para outros materiais de comunicação (FIGURA 104).

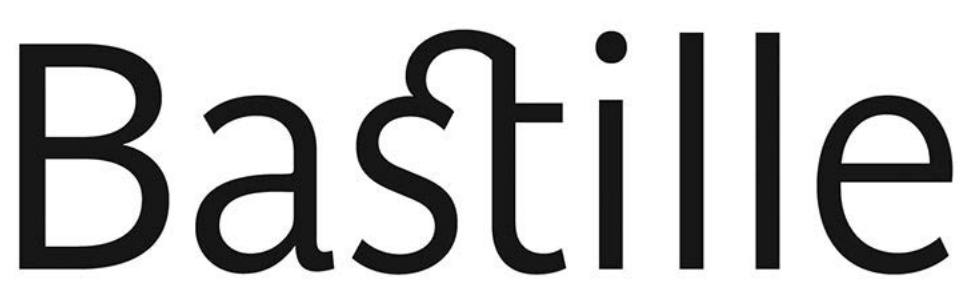

FIGURA 104_Ligatura discricional da Parisine, não

Enquanto o design da Parisine Bold e Bold Italic já estava na fase final, os designers da RATP as testaram na cartografia e em outros materiais de informação, em corpos muito pequenos. Como essas peças ainda eram compostas com a fonte Helvetica cujo resultado não era satisfatório, logo surgiu a necessidade de criar uma versão mais leve, mais legível compatível para essas situações. Prevendo um uso mais amplo da Parisine para todos os materiais de comunicação e considerando-a um elemento importante no projeto da identidade global da instituição Porchez propôs ampliar a família para três subfamílias: Parisine Clair Parisine e Parisine Sombre, cada uma composta da série básica de pesos regular, itálico, bold e bold itálico, totalizando 12 fontes. Distribuídas dess a forma, as fontes poderiam funcionar corretamente quando nomeadas nos sistemas operacionais Mac/OS e Windows. Os pesos mais extremos foram necessários para auxiliar o contraste nos textos aplicados nos mapas, por exemplo. A família ficou pronta para uso em 1999 (FIGURA 105).
PARISINE, parisine clair regular PARISINE, parisine clair regular Italic PARISINE, parisine clair bold PARISINE, parisine clair bold Italic PARISINE, parisine regular PARISINE, parisine regular Italic PARISINE, parisine bold PARISINE, parisine bold Italic PARISINE, parisine sombre PARISINE, parisine sombre italic PARISINE, parisine sombre bold PARISINE, parisine sombre bold italic

Posteriormente, outras duas versões intermediárias foram incluídas, a Parisine Gris e a Parisine Gris Bold, homogeneizando a grade de pesos e elevando o número total para 18 fontes. Essa família tipográfica atendia a quase todas as demandas gráficas mais imediatas da RATP, como a sinalização das estações do metrô, ônibus (FIGURA 106), trens bondes, além de materiais gráficos diversos, como cartografia (FIGURA 107), cartazes e comunicação publicitária.
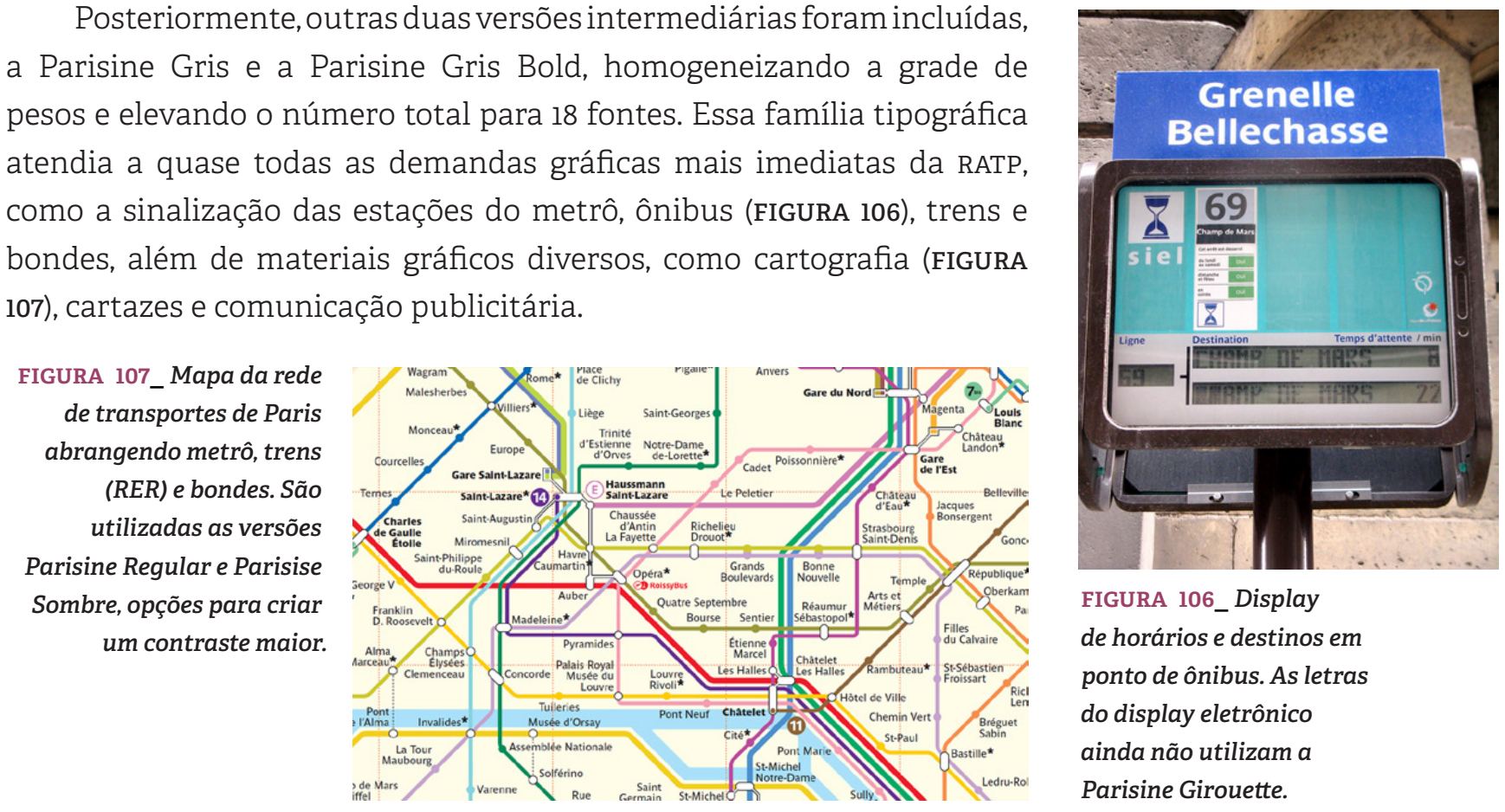
aabcddeeffgghiijk kllmnopqqrrsstuu vwwXxyyzzAABCD EEFGGHIJ]KKLM MNOPQQRRSTUU VWWXYYZ\&E0011 22334455677899\$ $\$ \$ \notin £ £ € € ¥ ¥ f f[@ ? !\}$ §gण), . Bfififlflfffll

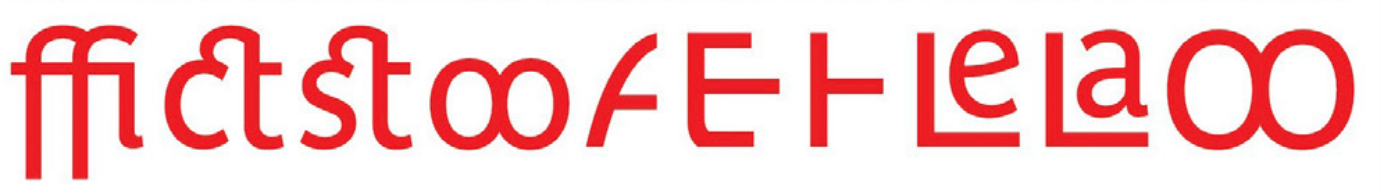

4.2.2.1 Parisine Plus_Logo que a tipografia Parisine chegou às suas formas definitivas, Porchez desenvolveu um projeto pessoal paralelo baseado na Parisine. A Parisine Plus não faz parte do pacote de fontes usadas pela RATP, ao menos diretamente. $\mathrm{O}$ designer relata, em texto de sua type foundry, que se interessou pelas possibilidades formais mais ousadas que a Parisine oferecia, mas que não seriam viáveis para uma sinalização. Esse design é um contraponto à funcionalidade que a Parisine necessita ter e aplica a liberdade criativa em caracteres cujo desenho clássico foi subvertido, conforme Porchez descreve. A versão Plus oferece muitas ligaturas e formas estranhas que geralmente são encontradas em tipos serifados que expressam alguma conotação mais histórica (TYPOFONDERIE, 2015, s.n.). Entre as muitas formas inusitadas, se destacam as diagonais encurvadas do 'A, K, Y', um gancho vertical prolongado no pescoço do ' $G$ ', uma barra no topo do 'J', uma quina na parte direita do 'U', 'e' com barra encurvada, 'f' com descendente (mais comum em tipos itálicos) e ' $\mathbf{x}$ ' formado por dois arcos. Na versão OpenType, mais recente, foram adicionadas várias ligaturas e caracteres alternativos para as versões romanas com fortes características caligráficas, como o 'a, e, q, l, s' (FIGURA 108).

Parisine Office Regular Parisine Office Italic Parisine Office Bold Parisine Office Bold Italic

4.2.2. Parisine Office Mesmo com a Parisine finalizada e em uso, cerca de 15.000 postos da instituição ainda utilizavam a fonte Gill Sans para compor comunicações internas. Em 2005 Porchez foi novamente contratado para elaborar uma variação da Parisine, agora focada para documentos administrativos e aplicações em grandes volumes de texto. Para se ajustar ao seu propósito, a Parisine Office (FIGURA 109) possui 
as aberturas ligeiramente mais fechadas e suas proporções e métricas o se aproximam às da Gill Sans para evitar um impacto negativo na substituição da fonte que já estava em uso, aumentando ou reduzindo muito o volume de textos em documentos padronizados. As principais diferenças em relação à Parisine são: uma altura-de-x mais baixa, salientando as ascendentes, remates curvos no 'd, k, l, p, r, u', 'J' com descendente, perna do ' $\mathrm{R}$ ' com rápida curvatura na junção da haste e letra ' $U$ ' com quina no lado direito, uma reminiscência da versão Plus. Atualmente, mais detalhes formais e ligaturas da Plus foram incorporados à família Parisine Office que é comercializada para venda.

4.2.2.3 Parisine Girouette_ O último aporte para a família Parisine foi um design de 2012 que permitiu incluir a identidade tipográfica nos displays eletrônicos dos ônibus e sinais luminosos externos dos pontos de embarque (FIGURA 110). Esses painéis são confeccionados por fabricantes terceirizados que não possuem muitas preocupações com legibilidade, muito menos em preservar a identidade visual. Os painéis, compostos por luzes de LEDS, criam uma grade luminosa de pontos redondos. A difícil questão era adaptar o design da Parisine em um dispositivo com altas restrições, com baixíssima resolução, espaço 20 muito limitado, impossibilidade de ajustes finos do design, kerning e

\section{Porte d'orléans \\ 57 Pl Saint Georges \\ 72 Chatelet-Halles \\ 258 issu Val-de-Seine/Meudonis

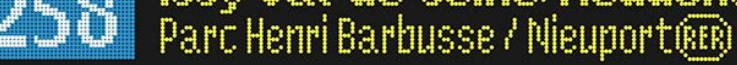 196 Issy Val-de-Seine}

outras condicionantes técnicas. Uma importante decisão foi trabalhar com o texto estático sem o movimento deslizante característico que prejudica muito a leitura. Partindo de um

05 diagrama modularizado, três tipografias foram idealizadas. A Parisine Girouette Frontale, é uma versão para as informações principais na frente dos veículos, tem sua altura-deconsideravelmente aumentada e é bastante

condensadaparapermitirumaproveitamento máximo do comprimento da linha de texto. Sua estrutura é baseada em 19 "pixels" (LEDS) de altura, da base à ascendente, por 3 pixels de peso das hastes verticais. Possui outras duas

5 versões secundárias, a Parisine Girouette Latérale, com a metade da altura da Frontale e usada para informações nas laterais dos ônibus. A opção bold é usada para indicar o destino final do trajeto (10 pixels de altura e 2

20 pixels nas hastes), enquanto a opção regular/ light (10 pixels de altura por 1 pixel nas hastes) indica as paradas intermediárias (FIGURA 111).

A limitação da grade de LEDS, obviamente, impede que qualquer sutileza do design da Parisine possa ser transferida para esse sistema.

A Girouette (cata-vento, em francês) é um alfabeto mais condensado com espaçamentos uniformes que se esforça em manter alguma relação com a fonte original, como as capitulares mais baixas que as ascendentes. Comparando com o as letras usadas anteriormente (FIGURA 112), a Parisin Girouette Frontale está mais preocupada em aumentar a legibilidade

30 em condições luminosas diurnas e noturnas, com maior conforto visual para o usuário.

\section{$\mathrm{RT} \mathrm{T}$} Docteur" Rouk
FIGURA 111_Amostra com as três 
4.2.3 Principais aspectos anatômicos da parisine_ A família Parisine é formada por quatro versões: Parisine (Standard), projetada para sinalização; Plus, idealizada para conter detalhes estilísticos mais livres; Parisine Office, projetada para uso administrativo e textos longos: e Parisine Girouette, projetada para aplicação em displays eletrônicos de LED. Tomando a versão Parisine Bold como referência, seu design é de um tipo sem serifa, com origem nos modelos neogrotescos (Helvética) tipos sem serifa humanistas (Gill Sans).

\section{ABCDEFGHIJKLMN abcdefghijklmnopq}

Os atributos formais da Parisine Bold (FIGURA 113) são:

Construção contínua dos traços;

Formas curvas contínuas são redondas, como no 'o' e as curvas abertas

são arrematadas com curvatura mais plana, como no 'a, e, c, f'

Hastes são verticais, paralelas retas, predominantemente sem remates das extremidades, com terminal curvo na letra 'a'. A posição da linha

média visualmente simétrica com leve tendência para a parte superior, como no 'B, E. F, H',

Terminais da hastes são retos e ortogonais e nas curvas possuem inclinação, como no 'C, G, e, S, s). Pingo das letras 'i, j' são circulares: Proporção é ligeiramente condensada, com as maiúsculas seguindo proporções regulares; a altura-de-x é alta com ascendentes mais altas que as maiúsculas;

Modelagem observa-se ausência de eixo inclinado, um pequeno

contraste com transição gradual

\section{OPQRSTUVWXYZ rstuvwXyz\&”@235}

Caracteres-Chave:

FIGURA 113_Parisine Bold destacada nas partes mais importantes dos caracteres chave.

a, gancho com curvatura plana, remate inclinado que remete à pena de bico chato conexão superior do bojo com a haste é abrupta e remate inferior curvo ;

$\mathbf{c}, \mathbf{e}, \mathbf{f}, \mathbf{r}, \mathbf{t}$, curvas planas, sendo ' $\mathbf{f}, \mathbf{t}$ ' com terminações mais longas; 0

15 remate das pontas são inclinados, assim como nos algarismos ' $\mathbf{2}, \mathbf{3}, \mathbf{5}$ '; $\mathbf{g}$, duplo andar, espinha horizontal e orelha retangular, horizontal e curta; $\mathbf{j}$, gancho curto e 'J' com gancho igualmente curto e alinhado pela base; t, cume chanfrado;

C, remates retos com inclinações opostas:

$\mathbf{K}$, assim como no ' $\mathbf{k}$ ', com junção dupla;

$\mathbf{M}$, com hastes laterais inclinadas;

Q, cauda reta, curta e inclinada à direita:

R, perna reta, diagonal e longa, seguindo a proporção das capitulares romanas:

', aspas e vírgula curvas;

@, composto pela letra 'a' em seu glifo de dois andares, como

representado na minúscula e anel circular sem contraste; 
4.2.4 O sistema de transportes identificado pela tipografia Parisine é tão ou mais legível que a Helvetica. Seu design com curva mais fluídas, suaves e suas estruturas menos "construídas", atribuem um caráter menos técnico e menos austero. Parisine se distancia da

Philosophie rigidez do design da Helvetica, é mais humanizada, não no sentido humanístico renascentista que se refere mais ao traçado caligráfico, Das pelo tratamento sensível que dá aos traços e aos remates. Suas formas seguem mais os movimentos da escrita e são suficientemente formas seguem mais os movimentos da escrita e são suficientemente aproxima mais do espírito tipográfico francês. Exemplo disso pode ser notado se compararmos as diferentes soluções para um mesmo conceito, encontrados no tipo alemão Walbaum (cerca de 1800) e na francesa Didot (1784), em que podemos perceber a construção robusta e precisa da primeira contra a sensibilidade, equilíbrio e fluidez da Didot (FIGURA 114). A diferença no aspecto ou na sensação de "peso" das formas entre a Parisine e Helvetica pode ser notada em simulações nas placas de sinalização. A Helvética desempenha a função informa com precisão, mas se torna frágil quando as pequenas aberturas das letras prejudicam a legibilidade e tem um aspecto mais impositivo. A Parisine, igualmente precisa, cria espaços de texto mais arejados por 20 causa das formas mais abertas das letras, tornando-a mais receptiv (FIGURA 115).

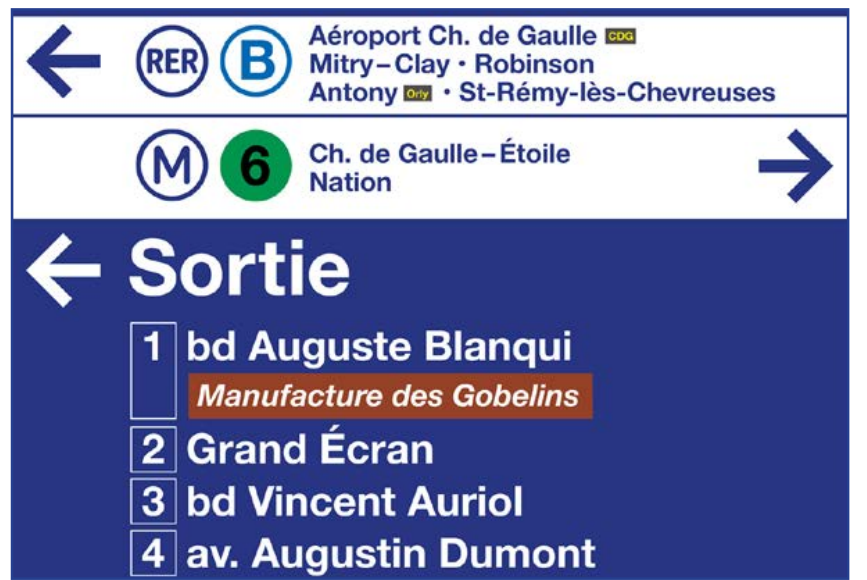

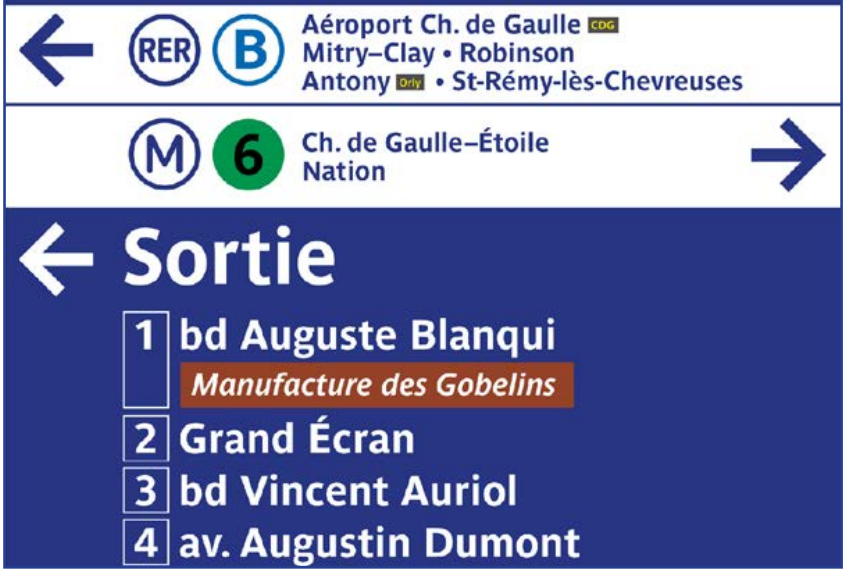

IGURA 115_Sinalização genérica composta em Neue Helvetiva (a esquerda) e a mesma placa composta em Parisine Bold (à direita) demonstra uma melhor economia de espaço, um ganho na legibilidade e no aspecto mais suave das letras.
FIGURA 116_Página de Relatório Anual da RATP, design do escritório Havas www utiliza a Havas www, utiliza a os textos.



Se a família tipográfica Parisine fosse implantada apenas na sinalização de placas e avisos do sistema de transportes de Paris, já teria causado um impacto considerável no cotidiano visual e na memóri

do usuário. Ouando a tipografia ocupa todas as instâncias em que a palavra e o texto são os únicos pontos de contado entre a instituição e seus usuários (FIGURAS 116 e 117), esta torna-se o principal elemento de identificação e de localização das pessoas dentro do sistema de transportes da cidade. Conforme aponta Rault (2014:28), do mesmo

3o modo que a comunicação visual do sistema de metrô de Londres marcado em seu histórico pelas tipografias de Edward Johnston e Eric Gill, se tornou parte da identidade londrina, a Parisine começa a construir a mesma imagem no imaginário do cidadão francês e dos turistas que vistam a cidade.

Atualmente, a família Parisine não é mais de uso exclusivo da RATP, sendo comercializada pelas type foundries Typofonderie e Zecraft de Jean François Porchez.
Espace

Pimprenelle

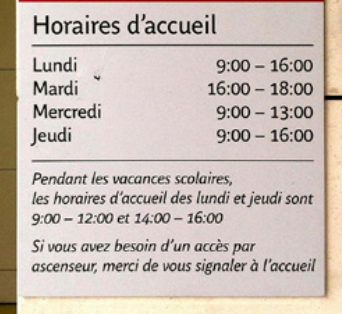

FIGURA 117_Placa de sinalização de horários do sistema de transportes RATP. 


\section{HSBC files}

The arms dealers, diamond smugglers, corrupt businessmen and drugs-runners. All clients of the bank

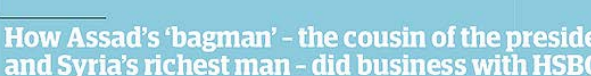
๑reges 45

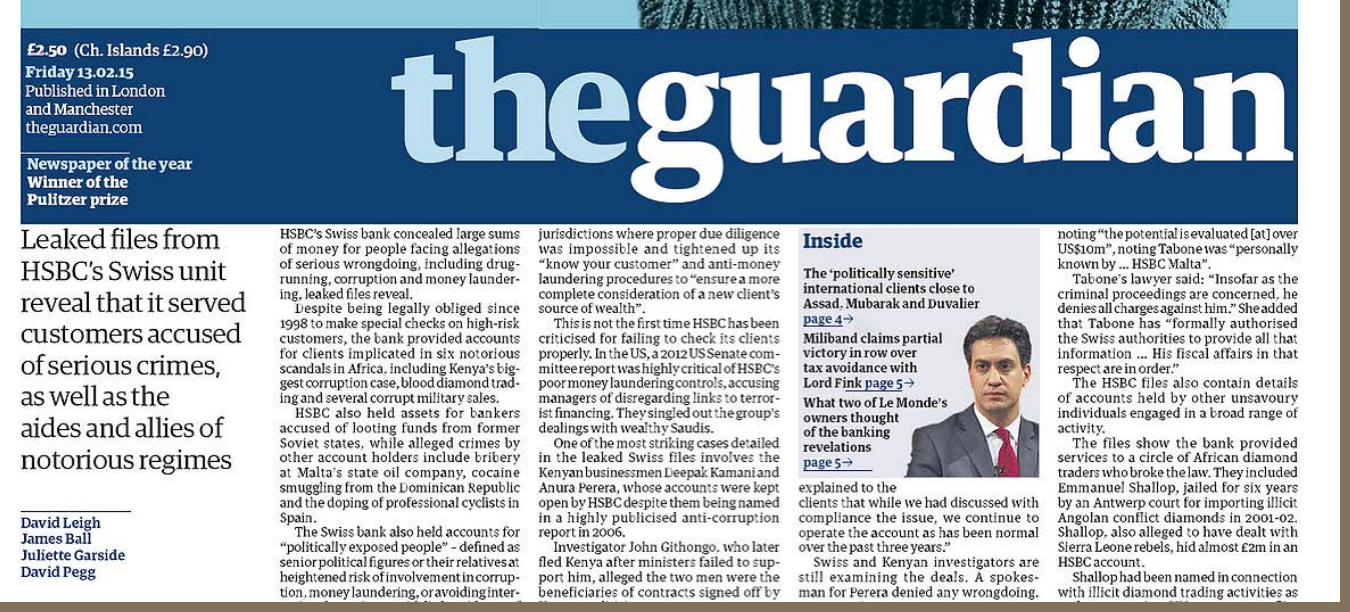

FIGURA 118_Capa do Guardian de 13 de fevereiro de 2015.
4.3 GUARDIAN EGYPTIAN E GUARDIAN SANS, 2005 o designer gráfico britânico Paul Barnes, juntamente com o designer de tipos norte-americano Christian Schwartz foram contratados pelo então diretor de criação do jornal The Guardian, Mark Porter, para a criação

05 de uma nova e exclusiva família tipográfica para o jornal: a Guardian Egyptian. Porter, que já havia trabalhado com Barnes nas revistas News Week, Esquire, Dimensions e Colors, foi responsável pelo novo design do jornal The Guardian e conduziu a introdução definitiva de cores a delicada transição do formato tradicional do jornal para o tamanho berliner - um formato de dimensão intermediária entre o tabloide o tamanho convencional de jornais, ou seja, em torno de $470 \mathrm{~mm} \times 315$ $\mathrm{mm}$ dobrado, formato que traz benefícios econômicos, de conforto de manuseio em espaços pequenos e aspecto de flexibilidade e inovação Apenas essa pequena modificação já seria o suficiente para a necessidade

15 de uma reformulação da composição tipográfica: a compactação dos espaços e diminuição da largura das colunas exige uma tipografia adequada e mais eficiente. Independentemente disso, a tipografi também poderia refletir mais enfaticamente o espirito da mudança. Some-se a isso a urgência em adaptar o jornal às mídias digitais de

20 pequeno formato como tablets e celulares, este último com redução do impacto das imagens e predominância da presença do texto. Segundo comentário de Porter em 2005:

Sempre tivemos a perspectiva comercial do que o jornal precisava ser, mas isso sempre estava equilibrado com o valor jornalístico que o jornal necessitava ter. Se todos estão gritando cada vez mais alto, a única maneira de você ser ouvido é falar em um tom de voz normal - ou até mesmo sussurrar (GUARDIAN, 2009, s.n. — tradução minha ${ }^{6}$ ).

30 4.3.1 A evolução do design do jornal até $\mathbf{1 9 8 8}$ _ o periódico Manchester Guardian foi fundado em 1821 por John Edward Taylor, publicado semanalmente até 1836 e diariamente, a partir de então. Editado em quatro páginas solidamente ancoradas em seis colunas de texto intercaladas por pequenas ilustrações, ganhou reconhecimento

35

60 "We had, at all times, the commercial idea of what the paper needed to be but that was always balanced with the journalistic value of what the paper needed to be. If everyone else is shouting louder and louder, the
only way you can be heard is by talking in a normal tone of voice - or even whispering" (GUARDIAN, 2009, s...).

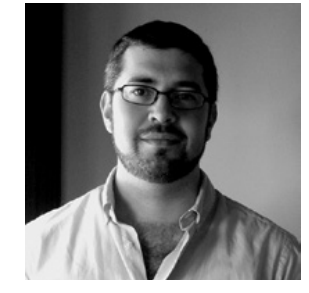

Christian Schwartz

Nascido em 1977, é graduado em Design de Comunicação, estagiou como designer de tipos no escritório Meta Design de Berlim e trabalhou na type foundry Fon Bureau em 2000. Desenhou fontes para a Emigré, FontShop, House Industries e Font Bureau. Foi premiado no Type Directors Club de Nova York e no Cooper Hewitt National Design Museum. Recebeu o prêmio Charles Peignot - Atyp en 2007. No mesmo ano, fundou a type foundry Commercial Type em parceria tinpera

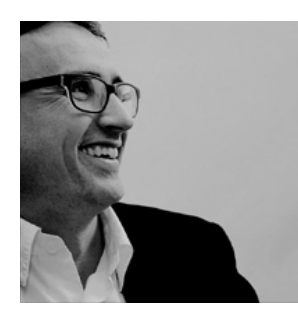

Paul Barnes

Nascido em 1970, é especializado em design gráfico editorial tipografia design de tipos e letreiramentos. Trabalhou com o designer Roger Black nos redesigns da revista Newsweek, Esquire e Foreign Affairs. Atualmente trabalha em Londres, em projetos de identidade visual para Givenchy e para bandas de música pop. É consultor da The Sunday Times Magazine, Wallpaper Harper's Bazaar e The Guardian, no qual desenvolveu a família tipográfica Guardian Egyptian. Criou as tipografias Publico, Dala Floda, Brunel e Marian (COMMERCIAL TYPE, s.d. 


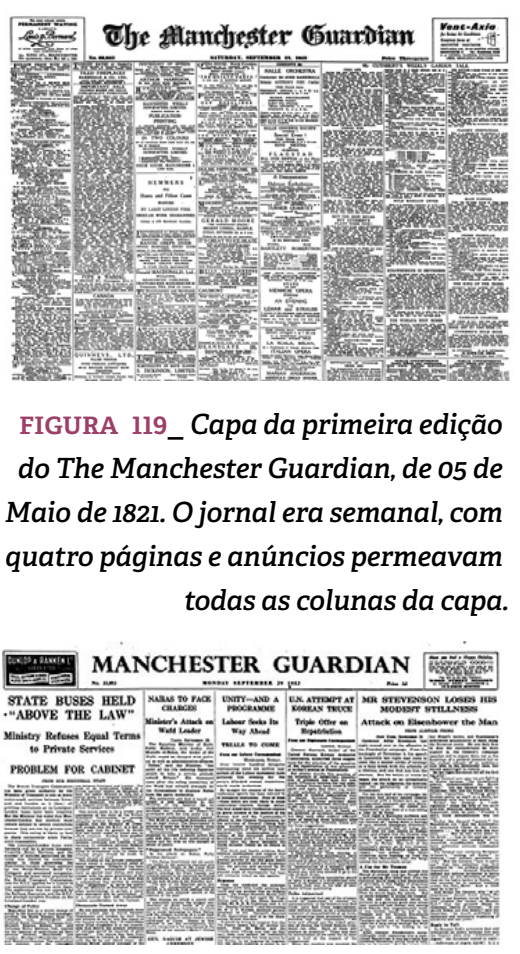

FIGURA 120_Em Setembro de 19520 editor Wadsworth remove os anúncios e mantém apenas notícias na capa.

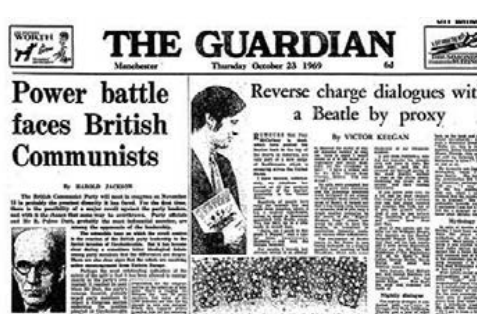

FIGURA 121_Exemplar de 1969 cujo nome assume definitivamente a forma atual de The Guardian.

FIGURA 122_Capa da edição de 2 de Fevereiro de 1988 inaugura o novo design de David Hillman que causou, inicialmente, alguma controvérsia, mas foi logo assimilado e elevado a modelo a ser seguido. Apesar das mudançase melhorias na tipografia, o design das matérias era carregado e denso. internacional no final do século XIX (FIGURA 119). Em 1886, ilustrações maiores foram introduzidas no miolo do jornal, seguidas pelas fotografias 22 anos depois. Em 1952, o título do jornal perde a palavra "The" (FIGURA 120) e, em 1969, é a vez de a palavra "Manchester" sair, em nome da distribuição nacional que o jornal assumia (FIGURA 121). Em 1986, o concorrente The Independent havia modernizado o próprio design e atraído leitores do Guardian. Nessa época, o design era composto por sete colunas de texto além de uma oitava coluna que, por vezes, desempenhava funções distintas (como "olhos", chamadas e destaques).

No ano seguinte, o jornal tentou reaver sua posição com um novo logotipo e tipografia. O requisito para essa demanda, segundo o editor assistente Michael McNay, era o jornal parecer "moderno, inovador, engajado" (GUARDIAN, 2005, s.n.).

O projeto gráfico, encomendado ao designer e tipógrafo do escritório Pentagram David Hillman, foi norteado por um briefing de poucas palavras: "queremos parecer modernos, informativos e comprometidos" (GUARDIAN, 1987, s.n.), e sua primeira edição foi publicada em 12 de fevereiro de 1988 (FIGURA 122). Segundo Rick Poynor (2005) o novo visual do jornal proposto por Hillman representou uma mudança radical, apesar de no início, muitos leitores expressarem descontentamento. Para ele, esse design "exalava autoridade ao mesmo tempo em que aparentava frescor, e era contemporâneo e acessível" (POYNOR, 2005, s.n.). A mudança mais evidente foi realizada no logotipo: em contraponto à tipografia serifada em um peso médio, toda em maiúsculas e centralizada no topo da página das edições anteriores, a nova proposta trazia o nome alinhado à direta e

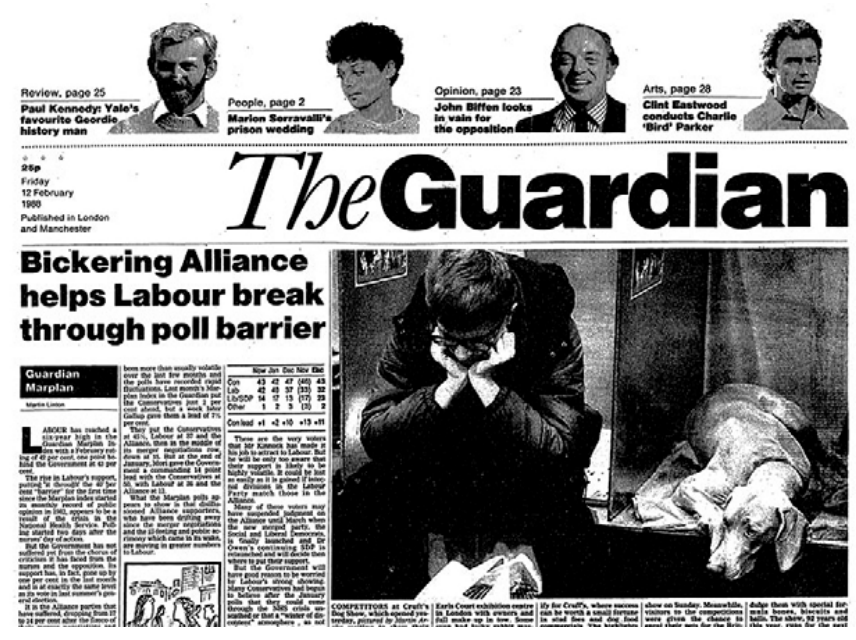

\section{The Guardian}

THE GUARDIAN
Monday May 301988

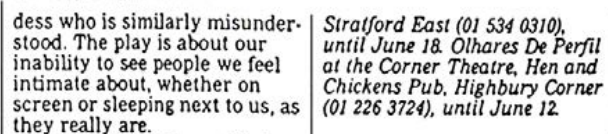
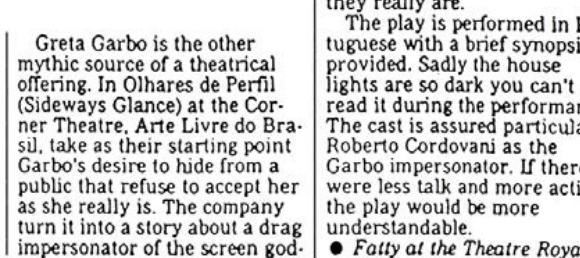

FIGURA 123_Logotipo criado por David Hill the Guardian grafado com duas tipografias diferentes, criandoritmo

abaixo de uma testeira com pequenas chamadas. A tipografia era composta por dois tipos em maiúsculas e minúsculas, diferentes e contrastantes: a palavra "The" em Monotype Garamond Italic e a palavra "Guardian" em

Neue Helvetica Black (FIGURA 123), sem espaço entre as duas palavras, criando um logotipo mais dinâmico e contemporâneo que inspira design de todo o resto do jornal. A distinção do novo logotipo fica evidente quando contraposto aos jornais concorrentes (FIGURA 124). $O$ design das páginas do jornal contava com uma nova grade de diagramação que permitia um espaço um pouco maior abaixo dos títulos e subtítulos. Os títulos, subtítulos, capitulares e demais conteúdos de destaque foram diagramados com a família Neue

Helvetica em variações de peso; uma linha acima de cada título reforça sua hierarquia e guia o leitor pela massa de informações; o texto, distribuído por oito colunas separadas por uma fina linha vertical, era composto pelo tipo serifado News Miller (Matthew

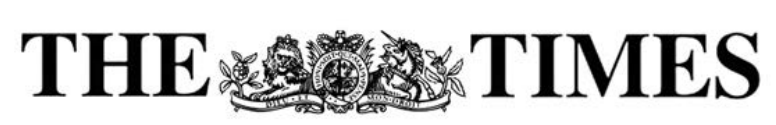

\section{THE $X$}

INDEPENDENT

The Daily Telegraph

\section{The Guardian}

30 Carter) cuja largura levemente condensada acomodava uma quantidad confortável de palavras por linha, adaptando-se à estreitas colunas e não interferindo demasiadamente no conforto de leitura. Alinhamentos e quebras mais agressivas em títulos também lhe atribuíram um aspecto mais jovial e dinâmico. Mas apesar da surpreendente inovação do logotipo e da nova paleta tipográfica, o design geral ainda permanecia carregado, pouco arejado, além de totalmente monocromático, não se diferenciando muito da versão anterior (FIGURA 122).
FIGURA 124_Comparação dos logotipos do The Guradian de 1988 com seus concorrentes diretos: The Times, no alto, The Independent $e$ The Daily Telegraph, todos em uso no mesmo período. 
FIGURA 125_Capa da edição de 12 de Setembro de 2005 que inaugurou o novo projeto gráfico e $a$ introdução da tipografia Guardian Egyptian. Uma barra com o resumo das principais noticias aparece acima do logotipo. Em um quadro no canto inferior direito, os editores celebram o novo formato berliner: "Maior nem sempreé melhor".

4.3.2 0 novo projeto gráfico de 2005_ A primeira edição do Guardian com o novo design foi publicada em 12 de setembro de 2005 (FIGURA 125), segunda-feira. Poynor (2005) menciona que a executivachefe do Guardian Media Group, Carolyn McCall, considerou a edição um momento histórico para o jornal. Ficaria imediatamente aparente aos leitores que a forma e a relação destes com os conteúdos de notícias habituais haviam mudado. A mudança para o formato berliner veio pela saturação do mercado jornalístico inglês e da própria ligação do leitor com o manuseio físico do papel. O desafio era manter a credibilidade conseguir atrair o público que gradualmente migrava para a leitura online.

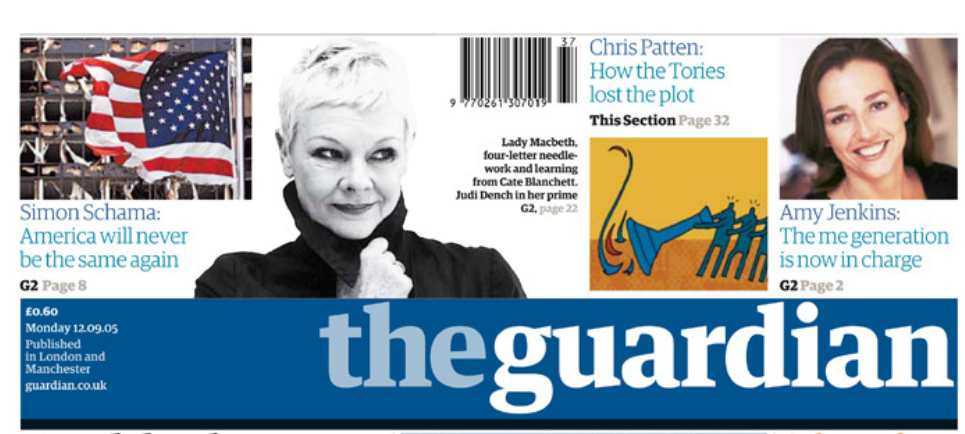

Backlash over Blair's school revolution
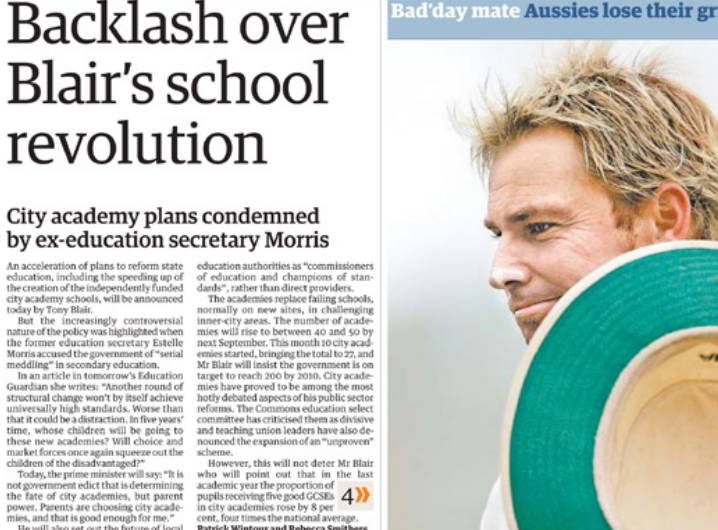

UK link to terror snatches
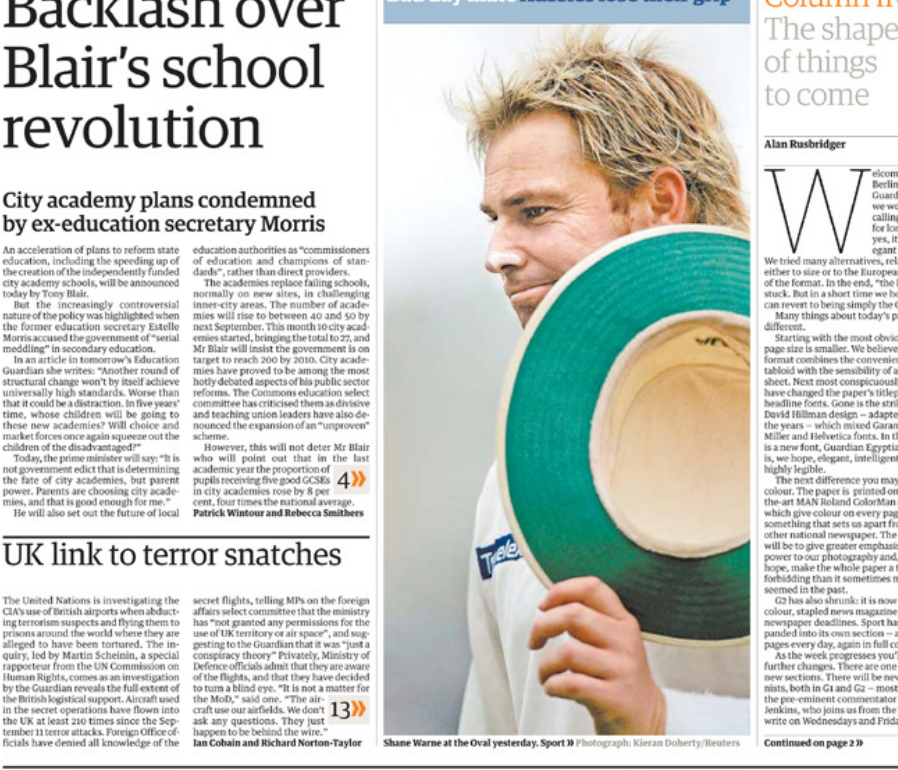

Tambem seus concorrentes The Independent e The Times já haviam migrado em 2003 para esse formato, não deixando muitas alternativas, senão acompanhar aquele mercado editorial (POYNOR, 2005, s.n.).

O novo projeto de Mark Porter resultou no primeiro jornal de grande circulação em formato berliner a ser impresso totalmente em quatro cores. Uma preocupação fundamental era tornar o design mais leve, sem deteriorar 20 a impressão de consistência de seu conteúdo jornalístico. A malha gráfica (grid) foi ajustada para cinco colunas de texto com largura de $53 \mathrm{~mm}$ e calha de $5 \mathrm{~mm}$ entre elas; o corpo do texto é composto em 8 pontos com entrelinhas de 9.5 pontos e o alinhamento do texto nas colunas é variante: as matérias gerais são justificadas, comentários e opiniões alinhadas à esquerda. $O$ espaço abaixo dos títulos subtítulos (linhas-finas) aumentou e grandes áreas de espaços vazios foram incluídas, favorecendo a clareza do design geral que impulsionam o leitor ao texto. Imagens e fotografias coloridas foram definitivamente incorporadas, ganhando grandes dimensões e alternando sutilmente com imagens em preto e branco.
O plano original era apenas adaptar o design do jornal para o novo formato, remodelando o design da tipografias em uso. Entretanto o tipógrafo Roger Black lembra que Mark Porter entendeu que uma transformação maior seria necessária para criar uma mudança mais 5 marcante e para enfrentar os projetos concorrentes, especialmente no ambiente da web:

o Guardian tinha entrado no jogo da internet muito bem. Neville Brody desenhou um website brilhante, o Guardian Unlimited. No entanto, isso não foi o suficiente. Porter queria uma mudança tipográfica completa para sinalizar o valor e a relevância do jornal com a mesma força que o design de Hillman tinha alcançado nos anos 1980 (BLACK, 2006, s.n. tradução minha ${ }^{(1)}$.

No decorrer do projeto, surgiu a demanda por uma nova e exclusiva família tipográfica, necessária tanto para se distanciar da combinação muito imitada da Helvetica Bold e News Miller como para oferecer uma maior variedade de estilos e consolidar a aparência mais tranquila e moderna do novo formato (BRANIGAN, 2005, s.n.).

20 A parte superior da primeira página também recebeu um tratamento mais atualizado e atraente. O logotipo de certo modo manteve a inovação instaurada por Hillman, aplicada na fonte Guardian Egyptian Text Black, em azul-claro para a palavra "The" e branco para "Guardian" sobre fundo azul escuro. Ancora-se na parte superior por uma barra com resumos de

25 notícias com informações que variam em cada edição, podendo conte nomes de articuladores e jornalistas ou chamadas para as matérias de maior destaque. Na parte inferior da página, abaixo do logotipo, a área é reservada para a introdução de matérias e imagens maiores. Na edição que circula aos sábados e domingos, acima do logotipo, uma grande área

reservada para chamadas de assuntos de maior visibilidade, tem apelo visual mais exacerbado (FIGURA 126).

Em edições mais recentes, o logotipo passou a ser aplicado em dois tons de azul sobre fundo branco, com a barra de resumos e chamadas logo abaixo, aumentando ainda mais o aspecto geral de leveza do design,

61 "The Guardian had played the Internet game very well. Neville Brody designed a brilliant website, Guardian Unlimited. Yet, that was not enough. Porter wanted a complete typographical change, to signal the paper's currency and relevance just as strongly as the Hillman design had done in the '80s'" (BLACK, 2006, s.d.).

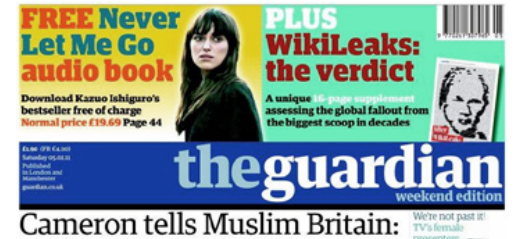

Cameron tells Muslim Britain

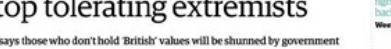

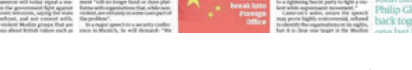

FIGURA 126_Cabeçalho da edição de fim de semana mantém a faixa as chamadas acima. 


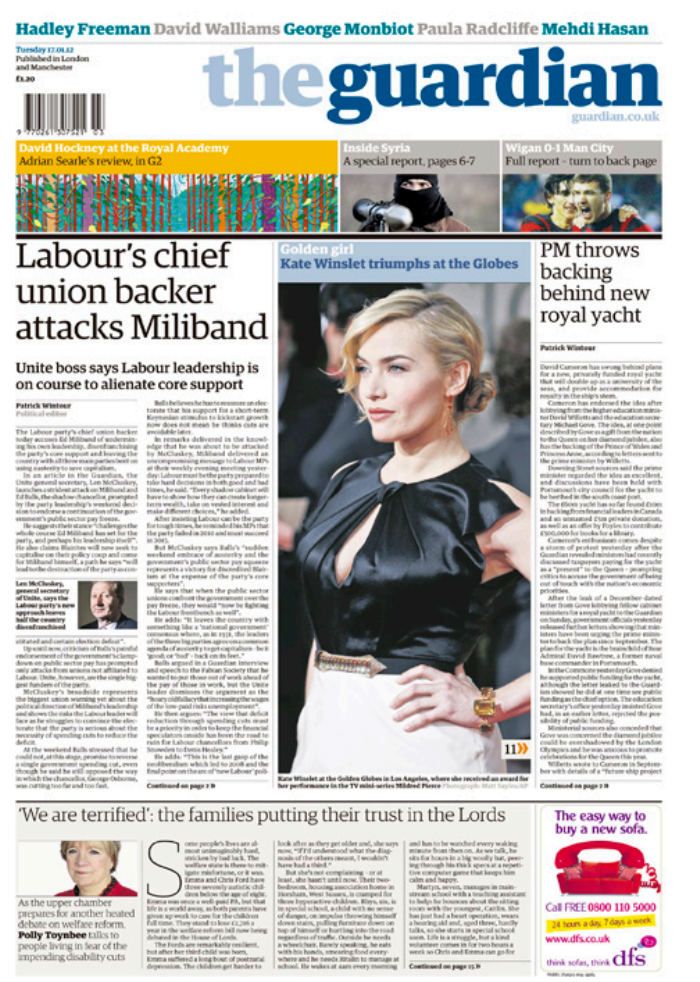

m detrimento do impacto visual da área superior (FIGURA 127). Se por um lado a redução do tamanho do jornal associada ao design totalmente colorido, mais limpo e arejado permiti maior criatividade, de outro ponto de vista desviou o aspecto tradicional com sua linguagem visual própria, aproximando-o do aspecto de uma revista e sua conotação de leitura mais ligeira e descomprometida (FIGURA 128).

4.3.3 As decisões conceituais para a nova tipografia O processo para a criação de uma tipografia customizada para - Guardian revela-se meticuloso e de múltiplas etapas para chegar à família tipográfica final, permeando modificações de fontes existentes e experimentações inusitadas até um design completamente novo. No final do ano de 2002, Porter e Barnes discutiram sobre como a nova tipografia deveria ser. Francesco Franchi (2013) aponta que Barnes imaginou duas possibilidades: ou as mudanças deveriam ser mínimas, como realizar versões customizadas da Neue Helvetica e Miller para funcionarem

FIGURA 127_Capa da edição de 17 de Janeiro de 2012. Oequilibrio entre imagens e massa de texto é auxiliado pelos espaços brancos abaixo dos titulos. A barra com resumo das noticias está posicionada abaixo do logotipo, que já aparece em letras azuis sobre branco.

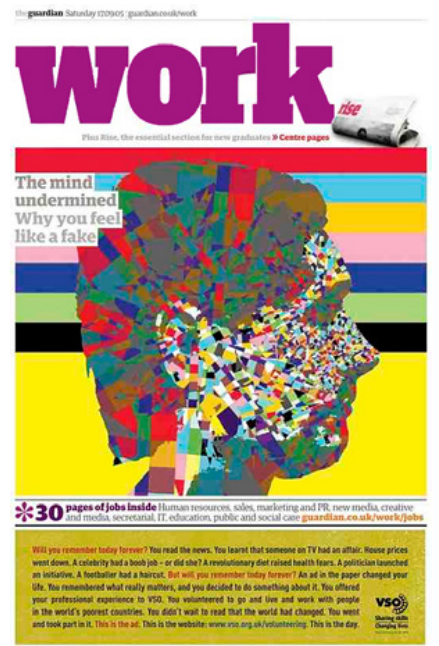
melhor juntas, ou, então, haveria uma mudança mais radical. O designer entendia que a Neue Helvetica (Linotype ${ }^{\oplus}$ ) não se adaptava confortavelmente aos títulos: a versão bold era muito expandida e não respondia bem ao ajuste de espaçamentos (tracking) mais apertado. Alguns pares de letras ficavam apertados demais, o que prejudicava a textura da linha (FRANCHI, 2013:108).

Barnes e Porter estavam impressionados pelo sucesso do projeto gráfico da revista Wallpaper que usou extensivamente tipos sem serifa. Portanto, o ponto de partida foi trabalhar em uma tipografia com essa característica, realizando uma adaptação da Neue Helvetica em vez de uma mudança total. Barnes considerou oportuno realizar um estudo dos tipos de metal original de 1957 e, a partir dessa referência, criar um design adaptado para o Guardian. Como a ideia era criar uma opção à Helvetica, Barnes convidou o designer baseado em Nova York, Christian Schwartz para se juntar à equipe por conta de sua experiência no design de tipos sem serifa. Iniciaram o projeto de uma versão renovada da Neue

IGURA 128 Capa do suplernento Work, de 17 de Setembro de

2005, com design de Mark Porter, demonstra a flexibilidade do

ovojeto grafico e o potencial expressivo da tipografic

Haas Grotesk (Ibid.). Na virada de 2003 para 2004, Schwartz desenvolveu um esboço completo dessa proposta, a Guardian Grot (FIGURA 129), com até seis pesos e versões itálicas com toques mais cursivos, como um 'a' de um único andar e um ' $\mathrm{f}$ ' com descendente.

Nesse momento, a ideia de criar uma fonte serifada customizada e proprietária, de caráter único e com necessidades particulares em mente, começou a ganhar corpo. Antes, pesquisaram algumas fontes serifadas disponíveis comercialmente ou em fase de finalização que pudessem se aplicar ao conjunto, ideia que foi logo abandonada por não se encaixar em todos os requisitos. $O$ passo seguinte foi desenvolver um fonte serifada, elegante o suficiente para acompanhar a Guardian Grot, o que conservava a dupla de tipos com e sem serifa. Barnes partiu da fonte Gulliver (Gerard Unger, 1993) e apresentou algumas possibilidades de design para testes em algumas letras apenas (hamburgefonstiv) com serifas mais ousadas e outras mais clássicas (FIGURA 130). Schwartz também acrescentou algumas sugestões de caráter mais histórico, como os terminais circulares das curvas abertas (Ibid.).

\section{Hamburgefonsti Hamburgefonsti Hamburgefonstiv Hamburgefonsti Hamburgefonsti}

\section{gestalt gestalt}

FIGURA 129_Comparação entre a Nene Helvetica gs Black e a Neue Haas Grotesk Black, base para o design da Guardian Grot de Christian Schwartz, mostram condensaçāo maior mais adequada aos títulos.

FIGURA 130 Esboços de algumas letras, explorando possiveis tipos de serifas e remates A primeira, ao alto éa versão que seria chamada de Stockholm considerada promissora mas ainda um pouco frágil. 
EIGURA 131_Amostra da tipografia Haçienda, desenhada por Paul Barnes, Christian Schwartz. Após ser descartada do projeto do The Guardian, foi rebatizada de Publico, para o jornal português

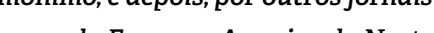

A opção mais promissora, inicialmente chamada de Stockholm e depois renomeada para Haçienda (FIGURA 131), foi desenvolvida em meados de 2004 com a intenção de ser "robusta, elegante e séria" (FRANCHI, 2013:109). Outra premissa importante era que a versão para textos longos deveria corresponder às métricas da fonte Miller, evitando desarranjos na composição já estabelecida. Haçienda foi trabalhada em diversos pesos e itálicos, com formas equilibradas e legíveis, mas apesar disso, não se encaixou na evolução do novo projeto gráfico que pedia uma 2 tipografia "menos austera e mais moderna". Suas proporções de alturade-x, ascendentes e descendentes, foram planejadas para combinar com a Guardian Grot, assim poderiam ser usadas misturadas e manterem a textura da massa do texto (Ibid.). Em palestra na conferência anual da AtypI de 2006, em Lisboa, Schwartz sinalizou a insatisfação com os rumos do projeto afirmando que "Em agosto de 2004, ocorreu a todos nós que algo não estava certo. A Helvetica estava muito relacionada ao velho Guardian e parecia faltar alguma coisa à fonte Haçienda" (Christian Schwartz, comunicação em palestra, ATypI 2006, Lisboa, 2006 - tradução minha ${ }^{62}$ ). Nessa ocasião, nenhum parâmetro mais concreto 30 foi exposto para justificar tal percepção, denotando uma atitude totalmente intuitiva, comum à prática do design. Em entrevista para a coluna Creative Characters, do site MyFonts, Schwartz revela o impasse no design e o desejo de guinar em outra direção:

62 "But in August 2004, it occured to us all something wasn't right. The Helvetica seemed to be too much of the old Guardian and the Haçienda seemed to be missing something" (Christian Schwartz, comunicação en palestra, ATypI 2006, Lisboa, 2006).
Paul Barnes e eu gastamos várias semanas em vão, tentando chegar aos esboços para a Guardian, até que paramos de pensar no modo obstinado de como queríamos que ela parecesse e começamos a focar mais no que ela precisava fazer - a afirmação de Mark Porter de que as páginas precisavam ser "modernas e austeras" desviou nossa atenção das infinitas variaçōes de formas serifadas e remates circulares, e nos deu

algo para continuar trabalhando (SCHWARTZCo, s.d. - tradução minhabi3).

Conforme o projeto gráfico de Porter se desenvolvia, ficava evident - que a articulação das duas famílias, Guardian Grot e Haçienda, não er mais convincente como um jogo confortável entre serifas e sem serifa, a ideia foi descartada. Insatisfeitos com esse resultado e determinados a explorar outro caminho para chegar a um tipo sem serifa plausível, os designers buscaram na tipografia do século xIX uma possível solução. A

15 jornalista Tania Branigan (2005), do Guardian, descreve o depoimento de Barnes em que ele cogitou voltar atrás e fazer um tipo egipciano ${ }^{64}$ e então retirar as serifas para compreender como deveria ser o tipo sem serifa. Depois, em acordo com Porter, decidiram torná-la novamente um tipo serifado, mais potente, uma versão intermediária entre as serifadas e as 20 sem serifa. Em outras palavras, é a "quadratura do círculo" como Porter esperava, unindo tradição e modernidade. "É limpa, sem ser impessoal", disse Schwartz (BRANIGAN, 2005, s.n.).

A dupla passou a trabalhar em um novo design de tipos sem serifa partindo de uma interessante experimentação de Paul Barnes:

baseado no pressuposto de que as primeiras tipografias sem serifa eram na verdade, tipos egipcianos com serifas quadradas que foram simplesmente removidas, Barnes tomou a Haçienda, transformou-a em uma egipciana, com suas serifas grossas, retangulares e diminuindo contraste das hastes, e depois eliminou as serifas. $O$ resultado foi a base

63 "Paul Barnes and I spent several fruitless weeks coming up with sketches for the Guardian until we stopped thinking so hard about how we wanted it to look, and started to focus on what it needed to dovariations of serif shapes and ball terminals, and gave us something to work towards" (SCHwaArzz 2007).

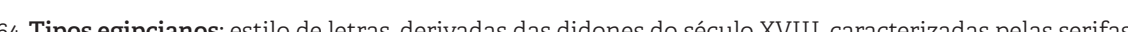

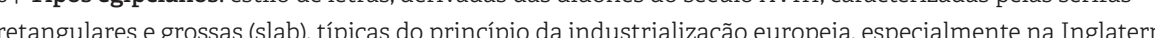
do século XIX (cf. Glossário Visual). Também conhecidas como 'mecanicistas' ou Egyptians. Segundo Alexander Lawson (1990:311), egipciano é o nome que foi dado às serifas retangulares devido ao crescente interesse pelo Egito, após a Batalha do Nilo (1798) vencida por Napoleăo, cujos saques lotaram museus franceses com artefatos historicos e exóticos daquele país. 
para desenvolver uma família tipografia que comportaria desde um tipo serifado para textos pequenos e para títulos até uma versão sem serifa coerente (FIGURA 132). Seguindo com o relato de Franchi (2013:110), a ideia era criar uma forma naturalmente compatível com as serifas, inserindo o design das egipcianas como um "elo perdido", uma ligação coerente para a forma ideal das sans, mas não para ser usada de fato. Mas o que foi projetado para ser apenas uma ponte de ligação para uma outra ideia tornou-se o foco principal: "Bingo! A egipciana parecia ter algo que era único; ela podia ser tão delicada como um tipo serifado e tão robusta como um tipo sem serifa" (Christian Schwartz, comunicação em palestra, ATypI 2006, Lisboa, 2006 - tradução minha ${ }^{65}$ ). De acordo com Schwartz

\section{Hamburgefonstivd} Hamburgefonstivd

\section{Hamburgefontsivd Hamburgefonstivd Hamburgefonstivd}

em texto de seu site, as fontes de referência para esse novo design foram os tipos egipcianos, de serifas grossas, típicos do período vitoriano que acompanharam a Revolução Industrial na Inglaterra de meados do século XIX em especial aqueles fundidos pela type foundry Figgins, para as romanas, e da type foundry Hugh Hughes, para as itálicas. O objetivo era combinar a tradição dos tipos ingleses com serifas quadradas com o estilo formal mais contemporâneo (scHWARTZCo, s.d.). Os designers perceberam que, do mesmo modo que a Helvetica desempenhou um papel forte nos projeto anteriores, essa nova tipografia poderia se tornar uma referência importante da identidade e da própria marca do The Guardian (FRANCHI, 2013: 110).

65 "Bingol! The Egyptian seemed to have something that was unique, it could be as delicate as a serif and as bold as a sans" "Christian Schwartz comunicaç̃o em palestra ATypt 2006 L Lisboa
4.3.4 Guardian Egyptian e Guardian Sans Para romper os laços com a fonte Haçienda, o projeto do tipo serifado foi nomeado provisoriamente como Porter Egyptian e Porter Sans (Ibid.)

o5 em uma clara intenção de conquistar a simpatia do exigente diretor de design (Figura 133). O briefing inicial foi revisado e agora a família deveria ser baseada em oito pesos para a versão serifada e nove pesos para a sem serifa, incluindo as respectivas itálicas. O desenvolvimento dos pesos partiram da versão regular (a mais usada nos textos corridos) , então, extrapolada para os pesos extremos, mais light e mais bold, ao contrário da prática mais comum de realizar primeiro os pesos mais

extremos e, depois, obter os pesos intermediário por interpolação. A definição da cor que as versões bold ou semibold deveriam ter, diversas variações de peso e espaçamento quase imperceptíveis (grades)

foram realizadas e testes impressos ajudaram a equilibrar e distribuir

o conjunto de pesos, evitando aquelas decisões fundadas apenas na intuição (FRANCHI, 2013: 111).

4.3.4.1 Guardian Egyptian_Nesta versão, em que a presença de serifas poderia criar uma sensação mais severa e grave, os tipos mantêm um aspecto claro e franco devido às aberturas generosas, como em 'a, c, e, $\mathbf{k}$

s. v, C. K, P, G' apontando na direção de uma estrutura tipográfica sem serifas (reforçada pelo baixo contraste) e revela uma nítida influência do estilo holandês (c.f. no capítulo 4.1.1). Evidentemente, trata-se de uma interpretação subjetiva desse aspecto, mas que pode ser respaldada tecnicamente pelas decisões formais adotadas durante o processo de

30 criação da fonte citadas anteriormente. Por sugestão de Mark Porter as itálicas deveriam seguir uma personalidade própria, diferentemente das itálicas cujas formas são subordinadas às romanas, agregando textura e alguma particularidade, uma vez que não se misturariam com as romanas e seriam usadas em destaques e alguns títulos. Como a Guardian Egyptian é inspirada em letras do século XIX, a intenção fo observar as itálicas do tipógrafo renascentista francês Robert Granjon "vestidas" como uma Egyptian (Ibid.:110) 
Guardian Egyptian Headline Hairline Guardian Egyptian Headline Hairline Italic Guardian Egyptian Headline Thin Guardian Egyptian Headline Thin Italic Guardian Egyptian Headline Light Guardian Egyptian Headline Light Italic Guardian Egyptian Headline Regular Guardian Egyptian Headline Regular Italic Guardian Egyptian Headline Medium Guardian Egyptian Headline Medium Italic Guardian Egyptian Headline Semibold Guardian Egyptian Headline Semibold Italic Guardian Egyptian Headline Bold Guardian Egyptian Headline Bold Italic Guardian Egyptian Headline Black Guardian Egyptian Headline Black Italic

Guardian Egyptian Text Regular Guardian Egyptian Text Regular Italic Guardian Egyptian Text Medium Guardian Egyptian Text Medium Italic Guardian Egyptian Text Bold Guardian Egyptian Text Bold Italic Guardian Egyptian Text Black
Conforme o projeto tipográfico caminhava para uma definição Guardian Egyptian criava o corpo central no novo projeto gráfico do jornal aplicada em todos os títulos. Para isso, um amplo estudo de variações pesos foi realizado: hairline, thin, light, regular, medium, semibold, bold,

black, todos com suas respectivas itálicas, totalizando 16 fontes. A versão Egyptian foi separada em duas versões, uma para títulos e outra para textos longos: a Guardian Egyptian Headline (FIGURA 134), e a Guardian Egyptian Text (FIGURA 135). As principais diferenças da versão Headline para a versão Text são: ausência de serifas verticais no topo do 'a, $\mathbf{f}$, deixando a fonte com características de texto mais adequadas; o cume do ' $t$ ' é levemente inclinado; a junção do braço e perna dos 'k, K' são separadas: o bojo do 'P' é aberto na parte inferior, detalhes visíveis em

\section{KPQHlafk KPQHlafk

tamanhos maiores mas inconvenientes em corpos menores: e cauda

do 'Q' ligeiramente mais curta e mais inclinada. Também a altura-de-x

20 é mais alta e a diferença das ascendentes para as maiúsculas é menor (FIGURA 136). As itálicas da versão Headline têm uma inclinação de cerca

de $16^{\circ}$, contra $12^{\circ}$ da versão Text, são mais condensadas

e apresentam alguns remates mais angulosos, como no topo nas minúsculas; e outros mais fechados, como no

remate do 'h' (FIGURA 137). A proporção é mais próxima à das versões romanas e traz remates mais curvados, ou serifas de transição, que permitem uma fluência maior nos textos corridos. Essas pequenas diferenças tornam a fonte dos títulos mais limpa e com textura mais

suave, e criam um aspecto mais moderno e de leitura mais fluída. Na versão Text, os recursos OpenType foram ampliados, como algarismos não alinhados ${ }^{66}$ (old style figures) e uma gama maior de ligaturas, frações e

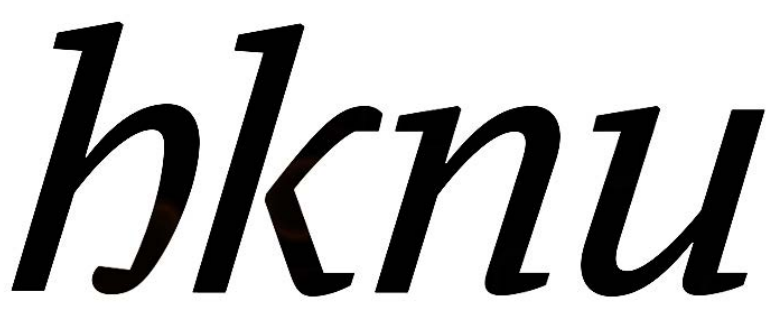
$h k n u$

FIGURA 137_ As itálicas da versão He dline (em cima) são mais condensadas do que a versão Text e, acompanhando as romanas, possuem alguns detalhes estilisticos como a curvatura da haste final do ' $h$ ', por exemplo. 


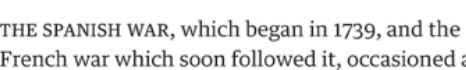
French war which soon followed it, occasioned
further increase of the debt, which, on the 31 sts December 1748 , after the war had been conclud
by the treaty of Aix-la-Chapelle, amounted to Ł78,2933,313. The most profound peace, of 17 years
continuance, had taken no more than $\varepsilon 8,328,354,17$ from it. A war, of less than nine years continua
added $331,338,689$ to oit. (Refer to Postlethwaites History of the Public Revenue.). During the admin-
istration of Mr. Pelham, the interest of the public reased, and some part of the public debt ws war, the funded debt of Great Britian oumounted

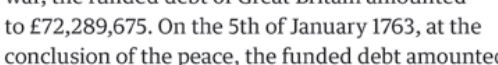

FIGURA 138_Guardian Egyptian Text aplicada ao texto: variaç̃es de estilo atribuem textura e hierarquia visual.

IGURA 139_As três versões da Guardian Sans: Text Headline e Agate. Sutilezas no design e nas proporçōes adaptam as fontes para várís (n) caracteres sobrescritos e subscritos e conjunto de caracteres versaletes, por exemplo, características apropriadas para a composição de textos com refinamentos hierárquicos mais complexos. Para permitir uma mudança de cor no texto sem alterar a diagramação, na versão Text os pesos regular e medium tem o mesmo ajuste de espaçamento (ou métric duplexed), não causando alterações no comprimento de linha quando mudanças de peso em palavras ou no texto inteiro são efetuadas, um recurso muito útil e tipograficamente refinado (FIGURA 138).

4.3.4.2 Guardian Sans_Seu design acompanha as fontes serifadas e foi projetada para títulos, subtítulos, legendas, textos longos e principalmente para tabelas, mapas e infográficos. Também foi dividida em três versões: uma para leitura em textos longos, a Guardian Sans Text; outra para títulos maiores, a Guardian Sans Headline; e uma terceira adequada para tamanhos muito reduzidos, a Guardian Agate (FIGURA 139).

\section{Guardian Sans Text Guardian Sans Headline Guardian Agate Sans}

3.43Guardian Sans Headline_Mantém o mesmo design da estrutura das Egyptian. As proporções holandesas e as amplas aberturas também estão presentes nessa versão, e sua métrica de espaçamento é quase idêntica à da Guardian Egyptian Headlines. Mais pertinente às tipografias sans serif o contraste é reduzido a quase nulo, a altura-de-x ainda é alt e as terminações das curvas soltas são ligeiramente afiladas. Essa versão combina perfeitamente com a versão serifada sem chamar atenção indevida para seu estilo e é apropriada para os títulos das revistas do jornal. Schwartz comenta que o processo para se chegar ao design do tipo sem serifa aproximou o resultado de outros tipos clássicos:

Nós a desenhamos usando exatamente os mesmos métodos que as antigas type foundries usavam para fazer seus tipos sem serifa - acabou ficando com um aspecto muito holandês, com uma pitada de Johnston. E por mais que não quiséssemos que não se parecesse com a Gill Sans, essa influência aconteceu aqui e ali" (sCHWARTZCo, s.d. — tradução minha ${ }^{67}$ ).

A maior contribuição incluída nessa versão é a extensão das variantes de condensações projetadas: normal, narrow, condensed e extr condensed, cada uma com nove opcões de pesos, do hairline ao ultra black com suas respectivas itálicas, totalizando 72 estilos diferentes

(FIGURA 140). Essa ampliação de larguras também aumenta as aplicações práticas para outras situações, como sinalização, cartazes e o desig de documentos corporativos. Além de criar um contraponto ideal para as versões serifadas, a ausência de serifas, historicamente, cria um ambiente mais descontraído e apropriado para certos assuntos ou "um voz perfeita para tabloides", como enfatiza o texto de apresentação comercial da fonte (SCHWARTZCO, s.d.).

4.3.4.4 Guardian Sans Text_ Esta versão foi desenvolvida para os textos especiais aplicados em barras laterais, capitulares ou qualquer texto em espaços limitados. Embora pouco utilizada no design do jornal nessa situação, a versão tem proporções mais condensadas, as curva são ligeiramente achatadas e se adaptam melhor a essa situação, o que é mais bem percebido nas curvas do 'o' por exemplo. Para ser mais legivel, o 'l' ganhou um remate curvo que ajuda na distinção entre o 'I' maiúsculo e o número um (FIGURA 141).

4.3.4.5 Guardian Agate Sans_ Para uso em tamanhos ainda menores, como editoriais financeiros, resultados esportivos, infográficos legendas, esta versão foi projetada para desempenhar suas funções em condições de impressão

muito desfavoráveis, como tamanhos abaixo de seis pontos impressos sobre papéis de baixa ou média calandragem, ou seja, uma superfície não

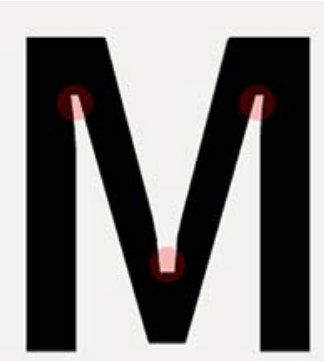

muito lisa. Partes de letras muito fechadas ou obstruídas, que podem comprometer a legibilidade, tiveram seus espaços brancos redesenhados

para criar a ilusão de correção em tamanhos muito pequenos. Essas compensações visuais a tornam inadequada para tamanhos maiores, de desenho. As compensações foram realizadas por fendas (inktraps), no mesmo estilo da fonte Bell Centennial de M. Carter (FIGURA 142), abertas em áreas em que as hastes se cruzam, criando uma aglomeração visual das formas como nas dobras verticais (ou, virilhas) das hastes de ' $\mathrm{V}$, X W, A, M, N'; na intersecção das barras com as hastes no 't' e 'f'; ou nas
Southampton Southampton Southampton Southampton FIGURA 140_Variaçôes de peso Headline oferecem flexibilidade de uso na composição de títulos.

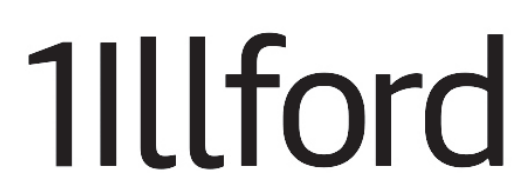
FIGURA 141_ Guardian Sans Text, projetada para textos pequenos, possui ajuste no design do 't' para maior diferenciação.

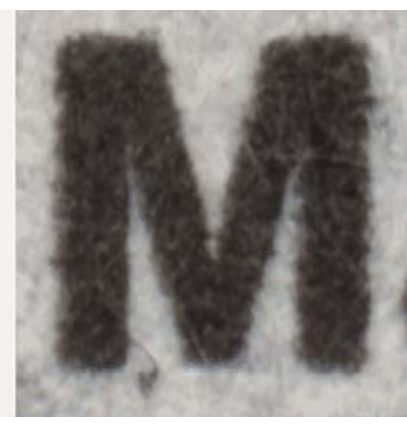

FIGURA 142_Detalhe da letras ' $M$ ' da Bell Centennial, de Matthew Carter 1976, com realce para as fendas que evitam o acumulo de tinta na impressio especialmente em corpos pequenose em papéis de baixa qualidade. Á direita o efeito da mesma letra impressa em corpo 6 pt. 
AGtrd

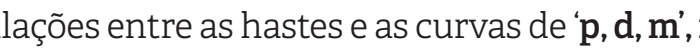
(FIGURA 143). A fonte é composta por dois pesos, regular e bold com itálicas, cada uma com quatro graduações tonais (grades), incrementos para um ajuste do peso de acordo com seu tamanho e cor do fundo sobre o qual é aplicado. visual na Guardian Agate Sans,

4.3.4.5 Principais aspectos anatômicos gerais da família Guardian__ A com fendas inseridas nos cruzamentos

de hastes. fonte que originou a família, definitivamente batizada como Guardian Egyptian, é um tipo serifado, com influências dos tipos vernaculares ingleses, especialmente os tipos conhecidos como egipcianos.

\section{ABCEGHJKMN} abcdefghijklmn

Os atributos formais da Guardian Egyptian Headline (FIGURA 144) são:

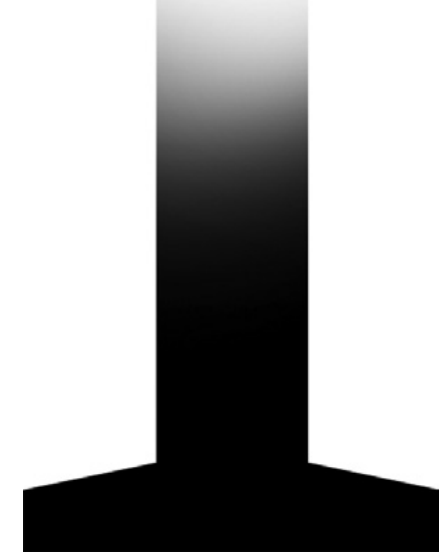

Construção contínua dos traços:

Formas curvas contínuas são mais retangulares, como no 'o'

berturas planas, como no 'a, c, s':

Hastes são verticais, paralelas retas e os remates das quinas são retos

e a posição da linha média, como no 'B, E, H' é visualmente simétrica: Terminais são serifas lapidares médias, simétricas, com cantos retos

base plana, sem junção (abruptas), levemente inclinadas (wedged

serifs) na parte superior e com espessura compatível com o contraste

o que confere aos tipos uma abordagem heterogênea clássica e

FIGURA 145_Detalhe da serifa da Guardian Egyptian Headline: un combinaçāo de serifa quadrada com serifa lapidar. contemporânea, afastando-se das soluções originais dos tipos de serifas retangulares (FIGURA 145). As serifas que arrematam as curvas e as hastes horizontais são ligeiramente inclinadas para fora;
Proporção é semicondensada, variando de acordo com as versões, maiúsculas com largura regulares, altura-de-x alta e ascendentes mais altas que as maiúsculas. A proporção das curvas mais "retangulares" têm alguma influência do estilo holandês. Essa influência fica evidente se compararmos a Guardian com a fonte Swift do holandês Gerard Unger, uma tipografia também projetada para jornais (FIGURA 146); Modelagem observa-se eixo racional (vertical), um contraste (variação de espessura das hastes) médio para a versão Egyptian com transição gradual e mínimo para as versões Sans;

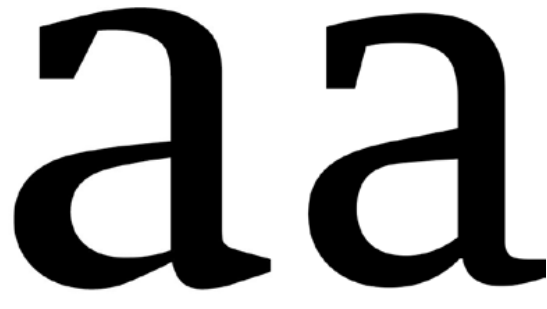

FIGURA 146_A semelhança entre a fonte Swift. à esquerda e a Guardia Egyptian Text, à direita. A segunda. tem menos contraste e remates mais afinados mas semelhantes nas proporcões e aberturas.
Caracteres-chave:

a, de duplo andar, ligeiramente condensada, guarda uma tênue ligação com traços humanísticos observados na articulação do bojo do 'a' e na barra do 'e'

a, c, e, f, y, os remates das partes curvas (ganchos) são adelgados

e mais horizontais;

g, de duplo andar, com orelha plana em forma de cunha e

laço ligeiramente inclinado;

t cume com sutil inclinação do lado esquerdo e barra com corte inclinado;

C, E, F, L, com serifas verticais inclinadas;

G, pescoço reto e sem espora de apoio

$\mathbf{K}, \mathbf{k}$, junção das hastes abertas, sem se tocar, assim como o bojo do ' $\mathbf{P}$ '
FIGURA 144_Guardian Egyptian Headline Regular destacada nas partes mais importantes dos caracteres-chave. 
$\mathbf{M}$, vértice ligeiramente suspenso, não é alinhado pela linha de base; Q, cauda em forma de cunha ligeiramente inclinada à direita, formada a partir da curva;

$\mathbf{R}$, perna reta e inclinada;

$\mathbf{X}$, haste diagonal mais fina, não é contínua.

4.3.5 A família tipográfica utilizada além das páginas do jornal Conforme descreveu Franchi (2013:113), ao longo do ano de 2005, a família tipográfica consistia de cerca de 200 fontes, das quais apenas $25 \%$ foram efetivamente utilizadas no jornal. Enquanto o veículo principal utiliza uma gama bem controlada de fontes, as revistas, suplementos e outras editorias utilizam quase todas as opções. A família tipográfica Guardian foi construída a partir de um único conceito e explorada em suas mais diversas variações, permitindo que o projeto gráfico do jornal e de toda a comunicação gráfica apoiasse fortemente suas composições na tipografia. Em algumas situações, a marca é usada de forma compactada, por meio de uma única letra ' $\mathrm{g}$ ' sobre um quadrado azul (FIGURA 147). Como a instituição é representada essencialmente pelo texto, a tipografia Guardian irradia os valores visuais do Guardian por todos os suportes de comunicação, incluindo sinalização, celulares, tablets e websites (FIGURAS 148), 20 colocando o leitor em contato constante com a marca.

FIGURA 147_Forma compacta do logotipo The Guardian, utilizada em sites de redes sociais, sintetiza seus valores institucionais pela tipografia e pela cor.

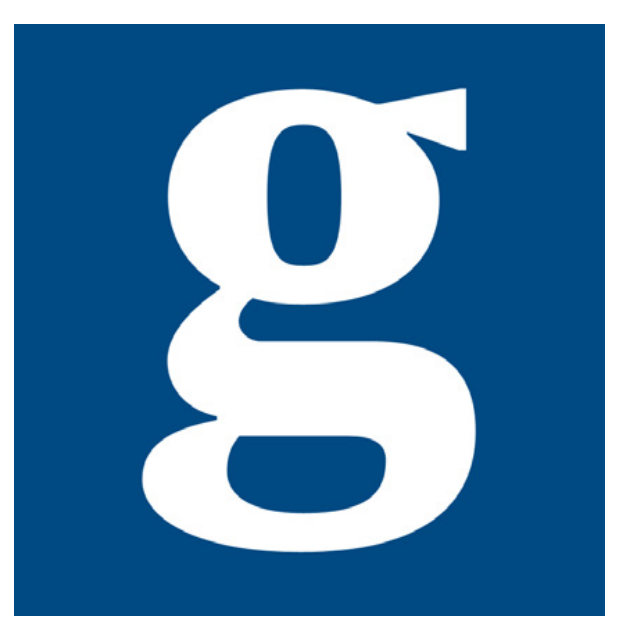

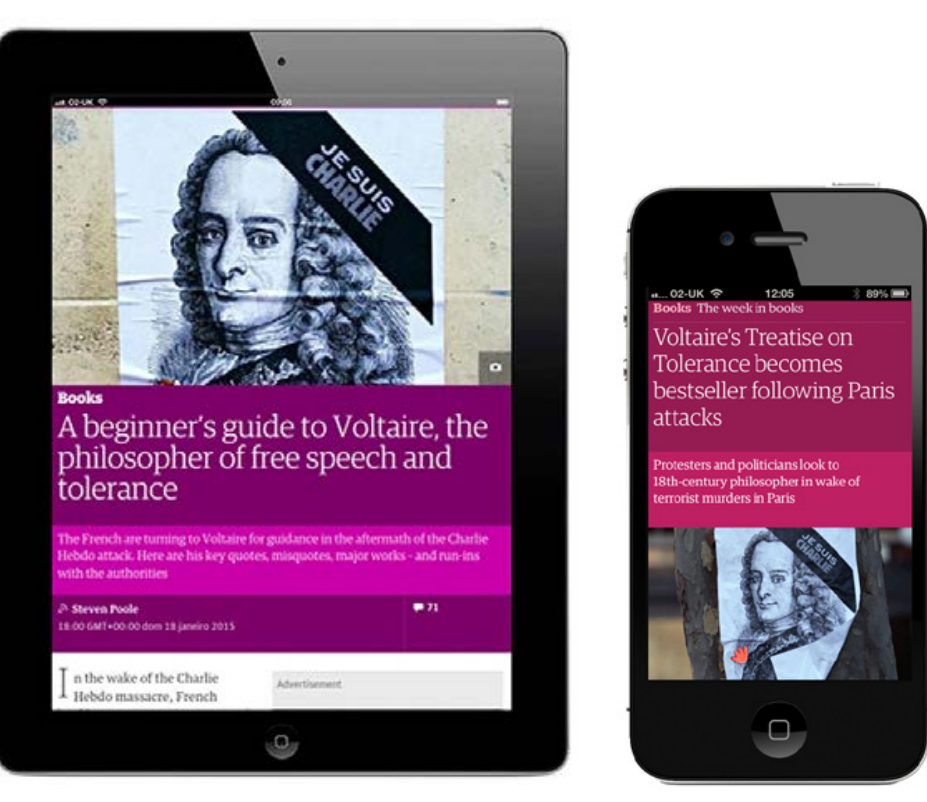

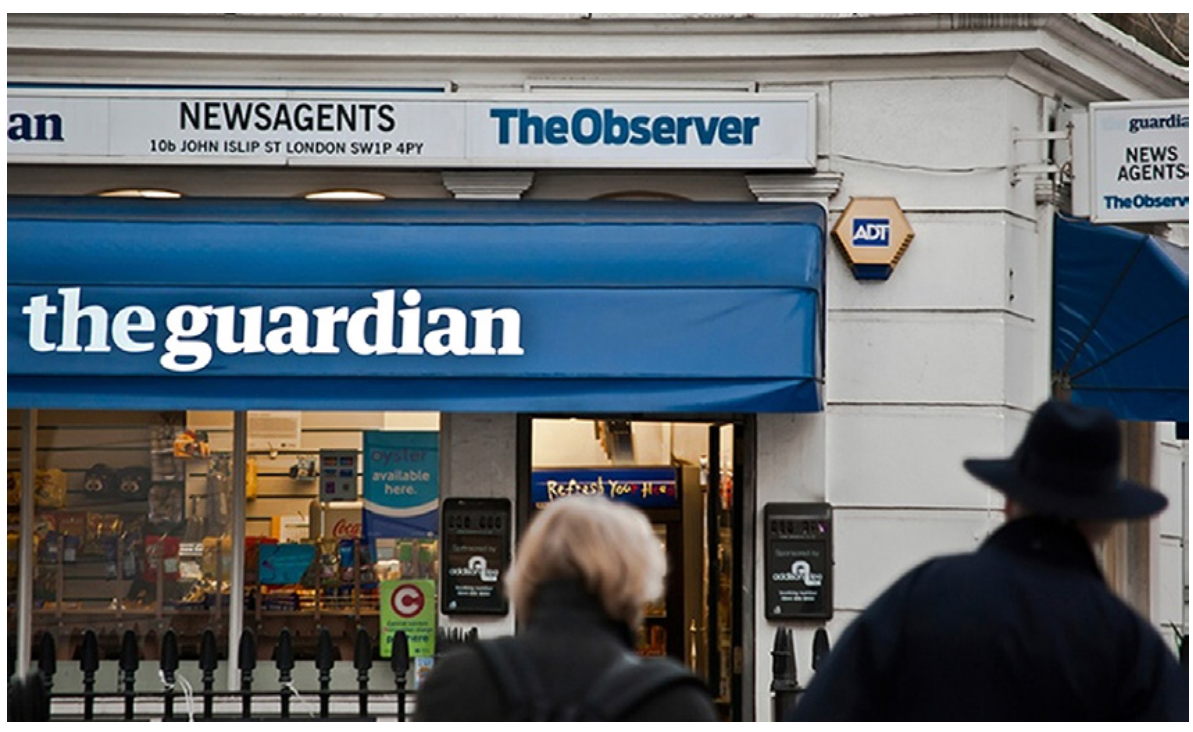

FIGURAS 148_A presença constante e consistente da tipografia Guardian Egyptian em todos os suportes de comunicação, desde a sinalização até o s dispositivos eletrônicos. 


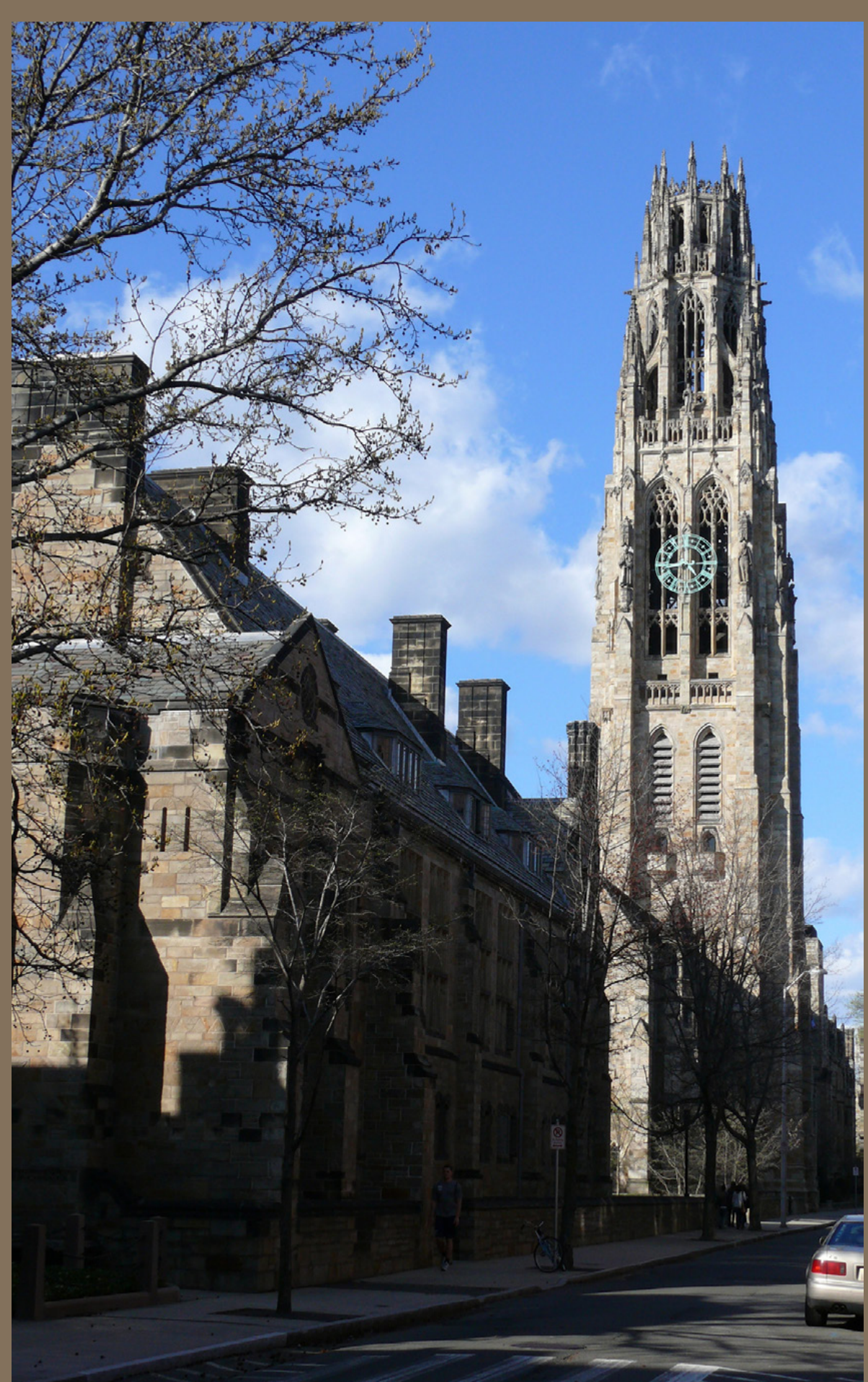

FIGURA 149_Vista do campus da Universidade de Yale e a emblemática Hakness Tower.
4.4 YALE, 2004_A fonte Yale, desenhada pelo designer Matthew Carter em 2004 para a Universidade de Yale (FIGURA 149), é um design inspirado na tipografia conhecidas como aldinas ${ }^{68}$ e que remontam ao final do século xv. O histórico gráfico da universidade está representado pela tipografia 05 com características desses tipos desde sua origem (FIGURA 150) e que, no século $\mathrm{xx}$, seria representado pelo tipo Bembo. A fonte Yale recupera a força dos originais que perderam algumas características no decorre dos processos de mecanização e digitalização dos tipos mais clássicos e reafirma a tradição de refinamento tipográfico da instituição. A nova tipografia foi implantada em todas os departamentos da universidade desde os documentos acadêmicos até a sinalização do campus, que foi efetivamente estruturada. A incorporação mais importante da fonte aconteceu na própria marca. Além do brasão tradicional que representa a institução, a marca criada por Paul Rand em 1985 (FIGURA 151) para a

15 Yale University Press é típica do estilo desenvolvido pelo designer e, segundo o depoimento que Drew Henderson obteve do impressor oficia da universidade, John Gambell, “Muita gente não gostou dele. [...] Muitos a consideravam um tanto assimétrica, não tradicional e um pouco difícil de decodificar" (HENDERSON, 2009, s.n. - tradução minha ${ }^{69}$ ). A tipografia 20 de Carter foi integrada ao logotipo em 2009, juntamente com a cor azul institucional (FIGURA 152), inspirada na cor dos uniformes tradicionais de períodos passados. $\mathrm{O}$ designer é conhecido, entre muitos projetos tipográficos já realizados, pela renovação e reinterpretação de modelos tipográficos históricos como os tipos Big Caslon, baseado na Caslon Old

Face; Galliard, baseada nos tipos de Robert Granjon; a Miller, inspirada nas romanas escocesas (Scotch Romans); Bell Centennial, um redesign da Bell Gothic; e muitas outras. Portanto, sua indicação para a tarefa certamente observou seu inegável currículo.

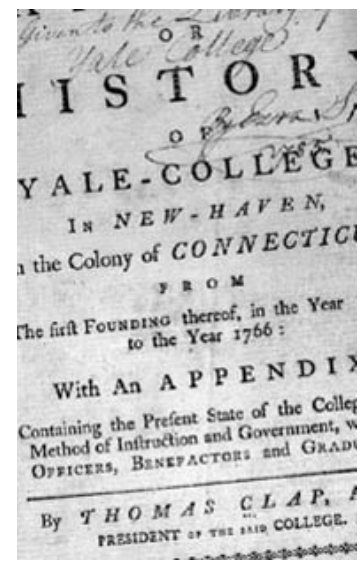

FIGURA 150 Os Anais da história da Faculdade de Yale em New Haven, de 1766 , impresso com um tipo aldino que seria utilizado como a tipograffa corporativa pelos próximos anos.

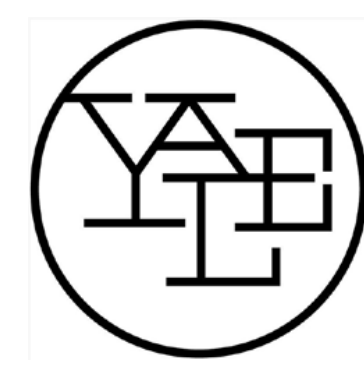

FIGURA 151_Logotipo origina desenhado por Paul Rand em 1985 para a Yale University Press. As quatro letras são entrelaçadas pelas serifas e, apesar de criarem uma forma única e compacta, também causaram lentidão na percep̧̧ão da palavra.

\section{Yale University}

FIGURA 152_Logotipo com a nova tipografia criada por Matthew Carter em 2004

68 Aldino: tipos que se assemelham em estilo e construçãa aos produzidos pelo editor Aldus Manutiuse pelo tipógrafo Francesco Griffo para a casa editorial veneziana de Manutius, entre $1494 \mathrm{e} 1511$ (BRINGHURST, 2005:352) 69 "A lot of people didn't like it," Gambell said. "A lot of people found it kind of asymmetrical and untraditional and kind of a little bit hard to decode" (HENDERSON, 2009, s.n. 
4.4.1 Griffo, Bembo e Yale_A origen da Universidade de Yale remonta ao ano 1640 quando clérigos coloniais procuraram estabelecer uma escola na cidade de New Haven, no estado norte-americano de Connecticut, com a missão de promover e manter os valores tradicionais da educação liberal europeia. Em 1718, a cidade conseguiu o direito de fundar a escola que foi nomeada como Yale College. Nos dois séculos seguintes, a instituição ganharia seu status com o estabelecimento dos cursos de graduação e de cursos profissionais. A universidade, que desde sua fundação se inspirou nos modelos de Oxford e Cambridge, é formada por três principais componentes acadêmicos: o programa de graduação da Yale College, o Graduate School of Arts and Sciences e um grupo de Escolas Profissionais. Completam a estrutura museus, galerias, bibliotecas e centros de programas de estudos. Atualmente abriga cerca de 11.000 estudantes de 109 países (YALE UNIVERSITY, s.d./a).

Conforme artigo de Brandon Jackson (2012,s.n.), Yale tem uma relação muito próxima com a tipografia. Desde sua fundação, sempre optou pelos tipos aldinos (venetian oldstyle), pois se trata de uma instituição muito tradicional. Uma das instituições da universidade é a Beinecke Rare Book \& Manuscript Library, uma biblioteca que abriga em sua coleção livros raros e manuscritos literários para pesquisa dos alunos e que, além de exibir uma cópia da famosa bíblia de 42 linhas de Gutenberg, guarda uma cópia de De Aetna, uma publicação emblemática impressa com tipos que se tornariam uma referência para as tipografias de modelo romano. Esse tipo foi desenvolvido por volta de 1495 pelo editor e impressor veneziano Teobaldo Manucci, mais conhecido pelo nome em sua versão latinizada - Aldus Manutius -, com a colaboração efetiva do gravador de tipos Francesco Griffo. Foi utilizado pela primeira vez no livro De Aetno de 1496 (FIGURA 153) do jovem cardeal Pietro Bembo (LAWson, 1990:77). um tipo serifado, idealizado para textos longos, classificado como aldino ou old style, com forte influência do traçado caligráfico. Nesse período, Veneza era um polo irradiador da cultura europeia, especialmente na produção de tipos móveis para impressão. Por ter sido amplamente distribuída por toda a Europa, a publicação influenciou o desenho dos tipos renascentistas que sucederiam, como os tipos do francês Claude Garamond (Ibid.:82). Manutius e Griffo também se tornariam memoráveis ao produzirem os primeiros tipos cursivos ou itálicos da história (1499-1501) para confecção de livros de bolso (BRINGHURST, 2005:139; DODD, 2006:25).
Séculos mais tarde, no ano de 1929, o tipógrafo inglês Stanley Morison da type foundry norte-americana Lanston Monotype Corporation, conduziu o projeto de recuperação do design do tipo usado em De Aetna, baseado em tipos móveis originais de Griffo e em espécimes impressos de qualidade

o5 precária (MEEGS; MCKELVEY, 2000:52), atualizando seu design para o século XX e para as condições técnicas dos dispositivos de processamento de fontes tipográficas (typesetters) vigentes (LAWSON, 1990:74). O resultado foi a tipografia Bembo, batizada com o nome do cardeal e foi utilizada por muitos anos pela Universidade de Yale como sua fonte primária (FIGURA 154) apesar de não ser uma prática constante e regrada. As versões mecanizadas e digitalizadas da Bembo, produzidas posteriormente pela própria Monotype $^{\oplus}$ (FIGURA 155) e Adobe ${ }^{\oplus}$, se adaptaram às exigências de um mercado mais amplo e perderam as particularidades e o vigor da referência original dos tipos aldinos de De Aetna (JACKSON, 2012, s.n.).

4.4.2 A tipografiaYale_Apesar de a tipografia Bembo prevalecer nas publicações, não havia uma normatização de seu uso como instrumento da identidade visual até o novo projeto de sinalização de 2002 começar a ser implantado. A sinalização dos prédios do campus ainda permanecia 20 entalhada em pedra nas paredes dos edifícios do campus em pesados tipos góticos (blackletters) ou outra letra de espírito medieval que combinasse com a arquitetura gótica vitoriana (HALLMUNDUR, 2009) ou ainda, um tipo que atribuísse algum ar sóbrio e solene.

Além do fato de a arquitetura do campus passar pelos estilos colonia

da nova Inglaterra e o gótico vitoriano, há periódicas intervenções que trazem seus ambientes para linhas mais contemporâneas. Exemplo disso é o interior da Biblioteca Beinecke (FIGURA 156). Em 1996, a diretoria

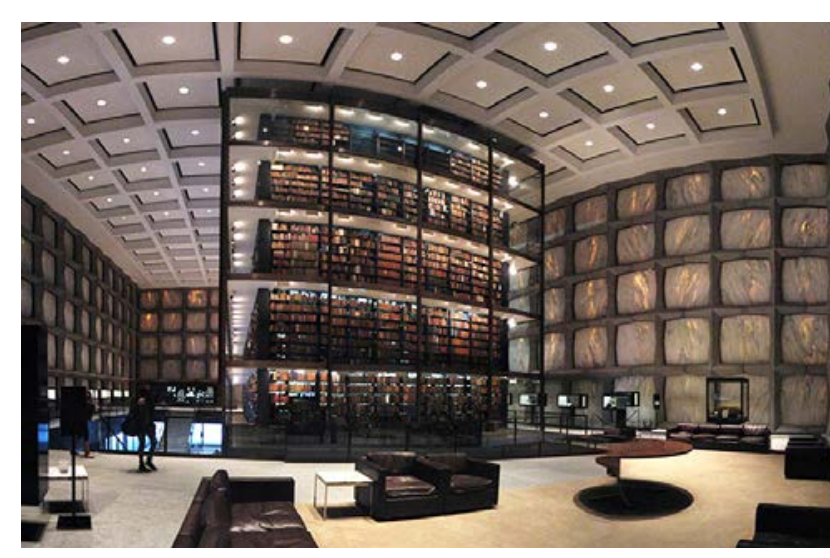

FIGURA 156_Interior da Biblioteca Beinecke, Universidade de Yale. 
da universidade já havia detectado problemas com a sinalização dos o1 edifícios e iniciou o processo para sua reformulação. Dois anos depois, um estímulo para uma reformulação da identidade visual geral da universidade veio com o trabalho de reestruturação do planejamento urbano do campus, cujo relatório realizado pela empresa de arquitetura Cooper, Robertson \& Partners identificou os problemas na sinalização ineficiente, muito incompleta e nada convidativa (NEEDHAM, 2008, s.n.). A direção da universidade aprovou em 2002 o projeto de um novo sistema de sinalização exterior que contou com a colaboração de representantes de diversas áreas da comunidade de Yale. O objetivo era proporcionar uma identificação uniforme dos prédios, eliminando a variedade de sinais pré-existentes, regularizando o design, os materiais e mensagens (YALE UNIVERSITY, 2014:07-09).

IGURA 157 Apresentação da tipografia Yale no tipografia Yale no website da universidade. a Yale Street e outra para uso geral em impressos, que seria mais tarde subdividida em duas versões destinadas a usuários diferentes, a Yale Design e Yale Administrative.
- A demanda mais urgente era pela tipografia para ser aplicada na sinalização, de acordo com as deficiências apontadas no relatório de 2000, que deveria essencialmente uniformizar a linguagem visual das placas de identificação dos prédios e outros sinais indicativos. Embora a

o5 escolha dessa versão para ser a primeira a ser projetada tenha ocorrido por motivos operacionais da universidade, também foi favorecida pela reabilitação de aspectos importantes do design original de Griffo, pois a fonte para a sinalização necessitava ser mais robusta e sólida nos detalhes, assim como nos tipos em De Aetna. Entretanto, Carter deixa claro que

tipografia Bembo Monotype ${ }^{\oplus}$ não esteve envolvida no processo (ANEXO I ${ }^{\text {T) }}$, mas não teve dúvidas ao começar o projeto indo diretamente às origens do design desse tipo, uma vez que a universidade tinha uma referência incontestável do desenho e do espírito originais que se queria recuperar.

Ciente de que a nova sinalização seria padronizada com letras maiús15 culas brancas sobre placas esmaltadas azuis, Carter percebeu a necessidade de observar as maiúsculas com mais atenção e estabelecer uma boa relação com as minúsculas. Em entrevista concedida a Paul Shaw (2011, s.n.), o designer relata que,

20 As placas, fossem elas soltas ou afixadas nas paredes, me lembraram inscrições, e isso me levou a pensar sobe as origens inscricionais das capitulares romanas e o eterno problema de conciliar maiúsculas com letras minúsculas. Para mim, o momento em que ocorre a primeira síntese verdadeira foi nos tipos usados em De Aetna. Por sua vez, isso me levou à Biblioteca Beinecke onde me debrucei sobre uma cópia do livro e seus tipos - na minha opinião, 0

arquétipo do tipo romano (SHAW, 2011, s.n. - tradução minha ${ }^{72}$.

$30 \quad$ O principal cuidado de Matthew Carter foi recuperar as sutilezas do design original dos tipos de Francesco Griffo que, no livro De Aetna, estão

"Bembo was not involved, except that it had been used by the University at an earlier date and therefore

estanding or attached to walls, reminded me of inscriptions, and this led me to

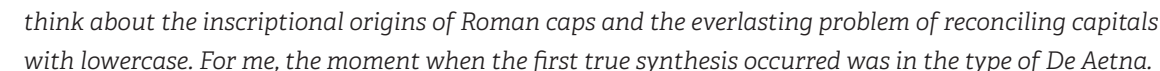
This led me in turn to the Beinecke Library to pore over their copyy of the book and its typee-the archetype of Roman type for me" (sAaw, 2011, s.n.). 
compostos em corpo $16 \mathrm{pt} \mathrm{e,} \mathrm{ao} \mathrm{mesmo} \mathrm{tempo,} \mathrm{criar} \mathrm{uma} \mathrm{tipografia} \mathrm{que}$ transmitisse um espírito de dignidade, conectada com seu tempo e com o ambiente em que seria usada, ou seja, o design deveria estar embasado em conceitos de tradição, solidez, integridade formal e estar associado ao público majoritariamente jovem frequentador da universidade e aos usuários esporádicos do campus. Na entrevista cedida a Paul Needhan (2008) para o jornal da universidade Yale Daily News, Carter afirmou: “A tipografia tem de ser usada em contextos muito variados, [...]. Portanto ela não pode ser muito excêntrica ou histórica demais. Mas também necessita ter um caráter único"73 $\mathrm{O}$ equilíbrio entre essas questões é sempre colocado à prova e é difícil de se alcançar ou de se constatar claramente. Na grande maioria dos casos, a percepção de atributos subjetivos, supostamente presentes nas formas e aspecto geral das letras, acontece por vias igualmente subjetivas, de natureza idiossincrática intuitiva. Uma questão que invariavelmente ocorre nesse tipo de projeto é se o espírito da instituição está realmente incorporado à tipografia. Ao designer, coube a tomada de algumas decisões mais fundamentais, como a de dar ao design das letras um aspecto imponente e afirmativo, mas sem perder certa leveza. Tais decisões podem ser notadas, por exemplo, na cauda da letra ' $Q$ ', longa e suavemente curva ou nos remates caligráficos de algumas curvas. Outra opção, por vezes empregada por designers, é a de referenciar algum aspecto físico do local, arquitetônico, paisagístico ou geográfico, alternativa que foi ironicamente refutada por Carter na mesma entrevista: "Vocês realmente queriam que a letra ' 1 parecesse com a Harkness Tower?" 74 (NEEDHAM, 2008, s.n.). A torre citad é uma edificação emblemática da universidade construída no estilo conhecido como Gótico Colegial, uma revisão arquitetônica adaptada do gótico inglês vitoriano (FIGURA 149).

Comparada com a fonte Bembo Monotype ${ }^{\oplus}$. Yale tem uma personalidade própria e uma regularidade de formas que um olhar mais atento pode perceber. Diferenças significativas podem ser notadas em grande parte das letras. Na fonte Yale, Carter estrutura as proporções sutilmente mais condensadas e restaura um peso mais robusto para as hastes. Elimina um detalhe típico dos tipos humanísticos venezianos como a

73 "The typeface has to be used in a great many contexts, from student papers to official publicentif)

(INEDHAM, 2008, s. . .

74 "Would you really want the lowercasel to look like Harkness Tower?" (bid.). saliência no bojo do 'e' mas acrescenta outras, como os remates caligráficos no 'a', aberturas amplas em c, e' e saliências pronunciadas na parte direita das ascendentes minúsculas em ' b, d, h, k, l'. Recupera e reforça a curvatura da haste direita do ' $h$ ', típica da versão original de Griffo e da versão da Bembo Roman Monotype ${ }^{\odot}$ e remodela o ápice achatado do 'A' com ligeiras saliências para os lados (FIGURA 159).

4.4.2.1. Yale Street_É a versão projetada apenas em romana, sem itálico, e em um único peso (FIGURA 160). Para obter uma leitura ideal de média a longa distâncias, recorre a espaçamentos maiores daqueles usados para impressão. É composta por letras

BGJKQW BGJKQW

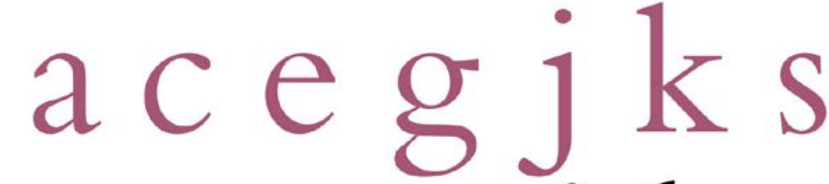
ace g j ks disponíveis em estilo alinhado (pelas maiúsculas) e não alinhado (old style figures). As proporções são mais condensadas para favorecer o ganho de espaço para as composições mais limitadas em tamanho para compensar o espaçamento entreletras maior. Em contrapartida, as contraformas são mais amplas e a altura-de-x, mais alta. Segundo Carter FIGURA 159_Caracteres da Yale Design Regular (em preto) comparados à Bembo Roman da Monotype $/(\mathrm{cinza})$. Ainda que as caracteristicas de uma estejam mantidas na outra, notam-se detalhes importantes

ABCDEFGHIJKLMNOPQR STUVWXYZ \&1234567890 abcdefghijklmnopqrstuvw xyz RA fl fi ff 1234567890

cuja tendência maior é que sejam vistos à distância, em condições de FIGURA 160_Tipografia Yale Street, iluminação muito variáveis e sob ângulos diversos, portanto estão a primeira versão projetada,é indicada

sempre no limite do que o olho humano pode captar (HALLMUNDUR, para leitura longas distâncias, ideal 2009, s.n.). Por isso, a espessura das hastes foi ajustada para serem mais pesadas do que uma fonte regular ou medium. Considerando que serão 
prioritariamente aplicadas na cor branca sobre fundos esmaltados azuis um ajuste óptico é necessário para manter a percepção ideal das letras. 4.4.2.2 Yale Design é uma das versões para impressão destinadas preferencialmente ao usuário mais especializado, caso dos designers gráficos, que produzem materiais de comunicação de natureza promocional, mais duradouros e voltados ao público externo como folhetos, programas, cartazes, catálogos, livros, relatórios anuais e websites insti-

\title{
ABCDEFGHIJKLMNOPQRS TUVWXY\&flfi,.:0123456789 abcdefghijklmnopqrstuvwxyz
} (ABOVE GEORGE W.PIERSON)

\author{
FIGURA 161_Yale Design, versão
} indicada para impressose para websites

que tenham significância institucionale

promocional.

tucionais. Portanto, é a tipografia que será mais exigida pelo programa de identidade visual. Suas características formais seguem a Yale Street, mas a espessura das hastes é um pouco mais leve, pois foi projetada para impressão em diversos tamanhos, desde títulos até textos miúdos. É composta por quatro versões, Yale Design Roman (FIGURA 161), Yale Design Bold e suas respectivas itálicas (FIGURA 162).

\section{ABCDEFGHIJKLMNOPRST} UWYabcdefghiklmnoprstuvwxyz

IGURA 162_Yale Design Italic, cujas minúsculas não têm serifas, da mesma forma como ocorre nas maiúsculas ou na versão Roman

Nas itálicas, as minúsculas destacam as caracteristicas mais particulares. As evidências de traçado caligráfico das letras cursivas estão presentes em todas as letras, notadamente na modulação da curva do 'a', e em uma pequena quina na contraforma do 'e' (olho). Os remates das curvas de ' c, f, $\mathbf{k}, \mathbf{r}, \mathbf{s}, \mathbf{v}, \mathbf{x}$ ' acompanham os mesmos da versão romana, que remete à pena de ponta chata. A serifa inclinada está presente apenas

no topo das ascendentes, no restante das letras, a terminação das hastes é formada por remates transitivos, como na letra 'n', por exemplo. Yale design tem recursos mais sofisticados de composição como as ligaturas 'ff, ffi, ffl, fi, fl' acessíveis por combinação do teclado do computador

(não é um recurso OpenType), travessões eme e ene com espaçamentos já definidos. Por estar disponível apenas nos formatos Type 1 e True Type, não há muitas opções estilísticas para caracteres ou conjuntos de caracteres especiais. Por isso, Yale Design tem apenas algarismos não alinhados, pois se referem a composições tipográficas de maior qualidade e, se for necessário usar algarismos alinhados, deve-se recorrer à Yale Administrative. O mesmo vale para o conjunto de caracteres em versalete (small caps), mas estes devem ser compostos usando uma fonte à parte, recomendada apenas para impressão, a Yale Small Capitals (FIGURA 163) cuja altura das maiúsculas é um pouco superior à altura-de-x.

4.4.2.3 Yale Administrative é recomendada para o pessoal administrativo interno da universidade que produz materiais de cunho informativo, como memorandos, relatórios, cartas, ordens de serviç̧o, etc. Também é indicada para textos que deverão ser convertidos diretamente para a linguagem HTML da web. Da mesma forma, é composta por quatro - versões, Yale Administrative Roman (FIGURA 164), Yale Administrative Bold e suas respectivas itálicas. Praticamente idêntica à Yale Design, apenas dois caracteres diferem: a letra 'Q' com a cauda mais curta e a letra 'f' com gancho também mais curto para prevenir

colisões com asletras ao lado oque evitaanecessidade de usar ligaturas. Os algarismos nesta versão são alinhados e

tabulares, estilo mais adequado para a composição de tabelas.

\section{ABCDEFGHIJ} KLMNOPQRS TUVWXYZ\& abcdefghijklmn opqrstuvwxyz 1234567890
ABCDEFGHIJ KLMNOPQR STUVWXYZ ABCDEFGHIJ KLMNOPQRS

TUVWXYZ\&

1234567890

FIGURA 163_Yale Small Capitals, uma com a Yale Design.

ABCDEFGHIJ KLMNOPQRS

TUVWXYZE abcdefghijklmn opqrstuvwxyz 1234567890

FIGURA 164_Yale Administrative, projetada para materiais internos de natureza administrativa, nas versões Roman e Roman Italic. 
4.4.2.4 Principais aspectos anatômicos da família Yale_O design básico da tipografia Yale é um tipo serifado, com maiúsculas derivadas do modelo das inscrições romanas e minúsculas baseadas na caligrafia não cursiva dos renascentistas italianos. Projetada inicialmente para uso em sinalização com versões seguintes para uso em impressos e web.

\section{ABCEGHIJKLMN abcdefghijklmnop}

HGURA 165_ Yale Design Roman, destacada nas partes mais importantes dos caracteres-chave.
Os atributos formais da Yale Design Roman (FIGURA 165) são:

Construção contínua dos traços, com evidências diretas da pena caligráfica de bico chato:

Eormas curvas contínuas são mais circulares, como no 'o', e as curvas abertas são arrematadas com curvatura descendente, como no 'a, c, f $\mathrm{f}$ ' Hastes são verticais, paralelas retas e remates das extremidades com serifas planas nas maiúsculas e na parte inferior das minúsculas e inclinadas no topo das minúsculas. A posição da linha média visualmente simétrica com sutis variações de altura no 'B, E, H, P, R'; Terminais são serifas próximas do tipo transicional, simétricas, cantos retos e base plana, com junção predominantemente curva, com pequena quebra (FIGURA 166). As serifas que arrematam as curvas hastes horizontais são inclinadas para fora, como no 'C, E, S, T, s, z' Proporção geral é normal, com as maiúsculas seguindo as proporções das capitulares romanas e as minúsculas sutilmente condensadas, a altura-de-x é média e ascendentes bem mais altas que as maiúsculas; Modelagem observam-se o eixo humanístico (inclinado à esquerda) e contraste alto com transição gradual.

\section{OPQRSTUWXY qrstuvwxyz\&flfi}

Caracteres-Chave:

a, com remate caligráfico que remete à pena de bico chato, e quina na parte superior do bojo;

b, sem espora no apoio e curvatura na parte inferior do miolo;

c, e f, r, remate caligráfico como no 'a'

g, de duplo andar, quina no início da espinha, orelha reta e horizontal; $\mathbf{h}$, com haste final curvada e ascendente com espora à direita, como no

b, d, l, e no topo do ' $\mathbf{j}$ ';

t, com cume triangular:

A, com saliências bilaterais no cume;

B, com bojo inferior não coincidente com o superior;

J, gancho com curvatura curta e descendente;

$\mathbf{K}$, assim como no ' $\mathbf{k}$ ', as hastes diagonais (braço e perna) não tocam a haste vertical;

M com hastes laterais inclinadas:

Q, com eixo humanístico, como no 'O' e cauda longa, com curvatura suave ascendente;

$\mathbf{R}$, perna diagonal, reta e longa que origina do bojo;

S, com postura ligeiramente inclinada à direita, característica dos tipos humanísticos.

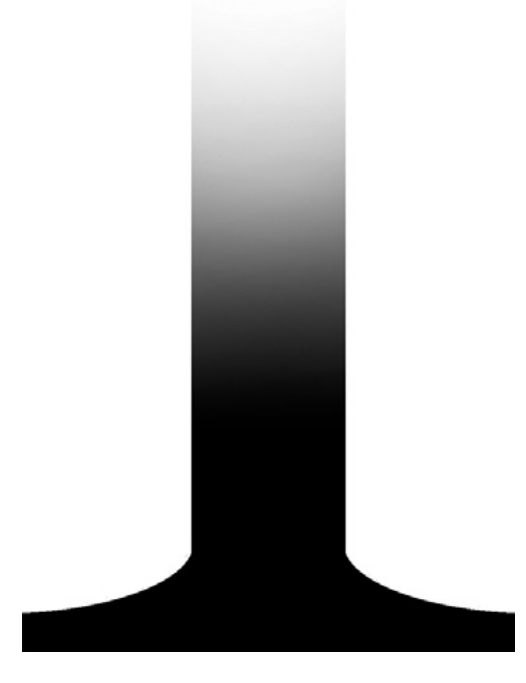

FIGURA 166_Detalhe da serifa da Yale Design Roman, onde se nota a "quebra" na calvatura da 
4.4.1 A identidade visual de Yale baseada na tipografia_Como já apresentado, a universidade conta com o Office of the University Printer, um departamento dedicado à produção e a manutenção da identidade visual da instituição. Seu diretor, o impressor da universidade John Gambell, acompanha e supervisiona a produção dos materiais editoriais e gráficos, impressos e digitais de maior relevância e visibilidade contando para isso com uma equipe de designers e editores no departamento. Gambell projetou a nova comunicação visual e normatizou o uso da fonte Yale, da sinalização do campus aos impressos mais corriqueiros para todos os departamentos da universidade, antes livres para usar tipografias de suas preferências. A identidade está apoiada nos três elementos essenciais do sistema (YALE UNIVERSITY, s.d./b): logotipo (puramente tipográfico) e seu sistema de marcas secundárias, cor e tipografia (FIGURA 167).

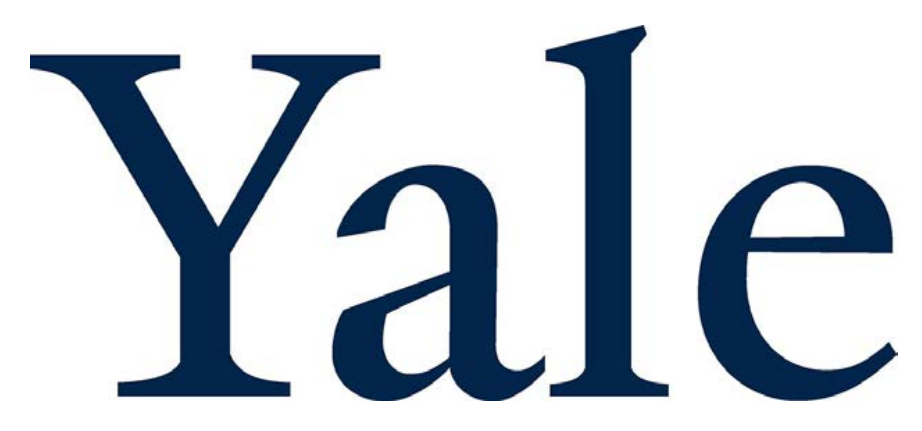

Yale UNIVERSITY LIBRARY Lewis Walpole Library

FIGURA 167_Detalhe da serifa da Yale Design Roman, onde se junção entre a serifa ea haste.

A fonte Yale, presente no logotipo e em todos os textos de publicações, está sempre associada à cor azul institucional e são os dois principais elementos que identificam qualquer comunicação gráfica da universidade. A regulamentação de seu uso está disponível no website da universidade, que apresenta um panorama da identidade visual, as principais orientações de uso dos três elementos básicos da identidade, assim como oferece alguns elementos-padrão para download. As informações são, na maioria, voltadas para as áreas editoriais, web e sinalização. Na seção reservada à tipografia, orienta-se que a fonte Yale pode ser acompanhada por tipografias com outras características, como uma fonte de serifa quadrada, uma sem serifa ou ainda uma manuscrita. Para esses casos, recomenda o uso da Serifa, Thesis Sans e Snell Roundhand, respectivamente. Para a web, a Yale pode ser aplicada
Choosing a style

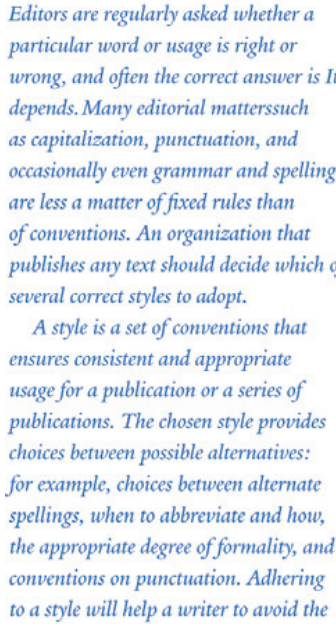

That cale Office of Public Aftairs \& Communications and the press relations staffs in ohhe

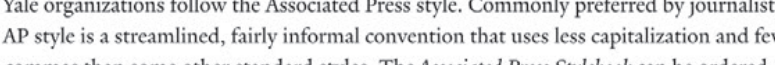
commas than some other stand. online at www.apsylebook.com.

The Reverend lan B. Oliver will be installed as pastoro of the Univeresity Churchor Sunday, Nov. 16. [NoTs lowercase pastor and abbreviation of November]] Oliver

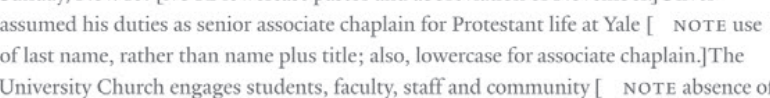

comma betre and conm

MLA Handbooks for Researchers
Scholarly publishing at Yale calls fes

政 anggage Association (MLA) publishes two versions of its style guide. The more

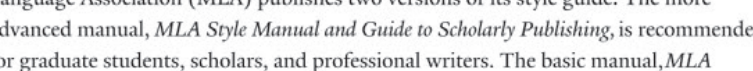

5 em sites desenvolvidos dentro da universidade. Se houver necessidade as fontes de Matthew Carter Verdana e Georgia podem ser usadas. Na area editorial, o site disponibiliza orientações de estilo de redação, mas a tipografia é empregada em todo o seu potencial e flexibilidade de opções (FIGURA 168). Como as fontes são disponibilizadas para todos que possuam - alguma conexão regular com a instituição, a tipografia adquire presença constante em qualquer material impresso de professores, alunos ou administrativos, especialmente aqueles publicados pela editora da universidade (FIGURA 169), criando uma cultura de identificação por meio da tipografia.

A sinalização pode ser desenvolvida pelos departamentos ou fornecedores externos de acordo com um Manual de Sinalização, com regula mentações de medidas de placas e todas as especificações referentes à aplicação das letras, como tamanhos, espaçamentos entreletras e entrelinhas, quebra de linhas e abre-

o viações. (FIGURA 170) As especificações ainda incluem veículos, testeiras de edifícios, sinalização interna das salas, mapas, placas honorárias e pictogramas.
FIGURA 168_Página do Manual de Estlio Editoria para publicaçōes da
Universidade de Yale.

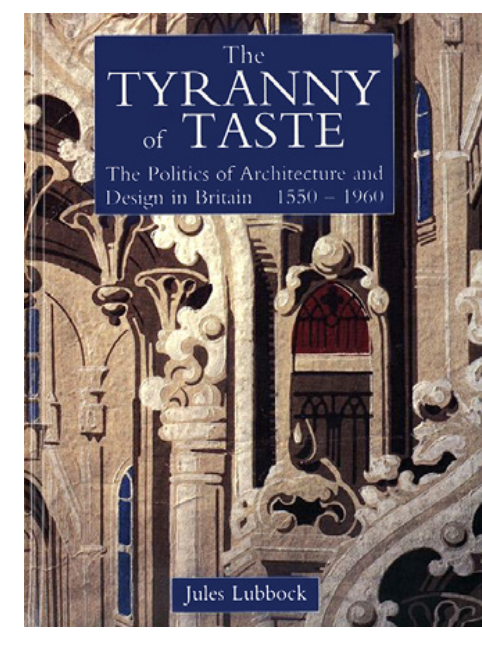
em 1995 pela Yale University Press. $\because$ 
O estilo arquitetônico do século xix das fachadas dos prédios da universidade, com suas rebuscadas estruturas revestidas em pedra ou em tijolos castanhos. é um cenário ao qual a tipografia Yale Street se ajusta bem, ao estabelecer um diálogo coerente com a estética os europeia de séculos anteriores, especialmente quando as placas azuis da sinalização são contrapostas arquitetura do local (FIGURA 171). Qualquer publicação que tenha em sua capa a cor azul no fundo e letras brancas compostas em Yale Design, é imediatamente 10 reconhecida como um produto da universidade.

FIGURA 171_A sinalização dos edificios em contrastes com a arquitetura do campus.
Toda a família tipográfica Yale está disponível para download no site da universidade para qualquer aluno, professor ou funcionário que tenha uma identificação eletrônica e senha de acesso. Essa prática possibilita, por exemplo, que os alunos utilizem as fontes para realizar todos os seus trabalhos acadêmicos. Visa também oferecer um ponto de contato maior e mais presente com o público, ou uma forma quase "viral" de promover a identidade de Yale, como afirmou o impressor Gambell (NEEDHAM, 2008, s.n.; HALLMUNDUR, 2009, s.n.). O uso da tipografia foi espalhado por todos os elementos que continham 20 alguma mensagem escrita:

No final de tudo, a tipografia Yale para a sinalização superou as expectativas de Carter. Desde 1701, Yale praticamente não tinha sinalização no campus, mas depois que a fonte foi projetada, havia sinais por toda a parte. Em suas próprias palavras, a tipografia teve uma 'ação viral' eficaz, surgindo não apenas nos prédios, mas também nos dispositivos de incêndio e até nos recipientes para reciclagem. Tudo o que pudesse ser, foi rotulado (HALLMUNDUR, 2009 - tradução minha ${ }^{\text {t) }}$.
Como é oferecida apenas à comunidade da Universidade de Yale a fonte se transforma em um tipo de código compartilhado, cria uma perspectiva de delimitação de um espaço e um sentimento de pertencimento entre seus usuários, uma das premissas fundamentais do

o5 estabe-lecimento da identidade (c.f. Capítulo 1). Como foi demonstrado, a fonte Yale reúne particularidades que a diferenciam de outros tipos cujo design tem a mesma origem, incluindo a própria Bembo. Logo, pode-se especular se os frequentadores assíduos do ambiente em que tipografia está largamente difundida seriam capazes de diferenciar a Yal

- de outras fontes muito semelhantes, atestando que detalhes aparentemente imperceptíveis nas formas das letras, podem exercer uma função identificadora em níveis mais profundos da memória (passim WALKER, 2007) o que, obviamente, só pode ser comprovado mediante testes e pesquisas.

Em agosto de 2014, a type foundry Carter \& Cone adaptou a fonte Yale 15 para o formato OpenType, a YaleNew. Essa família, composta dos mesmos estilos roman, italic, bold e bold italic, reúne em uma única fonte as anteriores Yale Administrative, Yale Design e Yale Small Capitals. A versão Administrative é o conjunto default da fonte e os caracteres alternativos, algarismos não alinhados e demais recursos que a Yale Design tinha 20 foram incluídos e são acessados pelo painel OpenType Features ${ }^{76}$ dos aplicativos. A Yale Street foi mantida inalterada e uma terceira versão, a Yale Display, acrescentada. Esta, é uma fonte romana de peso regular que foi aprimorada para títulos em tamanhos grandes acima de $24 \mathrm{pt}$ com contraste maior entre hastes grossas e finas, serifas mais refinadas,

25 altura-de-x maior e espaçamento entreletras mais apertado. 


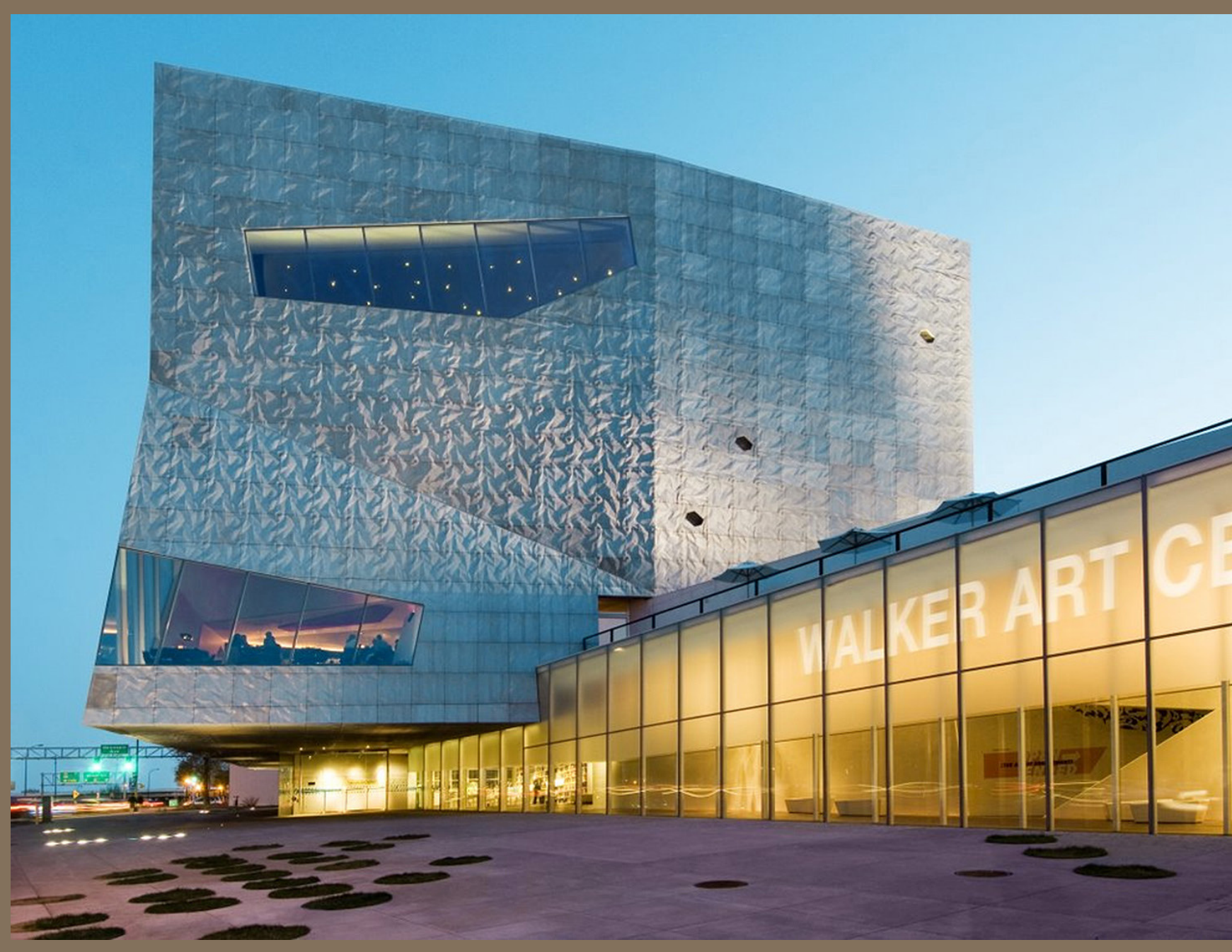

FIGURA 172_Fachada da novas instalaçōes do Walks

4.5 WALKER, 1995 Dastipografias estudadasneste capítulo, a Walker talvez seja aquela que mais mereça ser reconhecida como marca do que simplesmente como uma tipografia. Isso porque, de fato, ela assumiu a função da própria marca. As mudanças no perfil do público do museu

Walker Art Center e as diretrizes de inovação e multidisciplinaridade que nortearam o novo projeto de identidade ficariam limitadas sob um único sinal visual. Moira Cullen (2001) menciona que desde que o novo projeto gráfico começou a ser planejado no final de 1994, ficou claro que a noção de que uma identidade mais marcante, com elementos gráficos que estabele-

cessem uma imagem pública consistente seria conduzida e interpretada por meio da tipografia. O designer de tipos inglês, baseado na cidade de Boston, Massachusetts, Estados Unidos, Matthew Carter foi escolhido como opção única para conduzir a tarefa e logo expôs seu plano:

Carter participou ao quadro de executivos do museu que, com sua proposta a identidade da instituição seria transmitida não por um logotipo, mas por meio de uma família de letras com linhas horizontais variantes e tipos de serifas intercambiáveis - elas próprias caracteres dentro da fonte, que transformariam uma única e simples tipografia em uma voz polifônica (CULLEN, 2001:93 - tradução minha ${ }^{T}$ ).

Equipada com diferentes serifas opcionais, ligaturas especiais outras possibilidades de arranjo e composição do texto, a Walker é um das primeiras fontes interativas e cambiáveis, pois o usuário adquire

um grau elevado de interferência no aspecto e na disposição que a fonte terá no design. Essa característica da fonte é um marco na utilização de tipos digitais no design da imagem corporativa. O logotipo do Walker Art Center (WAC) é composto exclusivamente com a fonte de Carter em sua versão básica (FIGURA 173), sem nenhum acréscimo de serifas ou traços, O

30 que não impediu os designers do museu de subverterem essa obrigação

WALKER ART CENTER

3577 "Carter told the museum's executive board that with his proposal the institution's identity would be

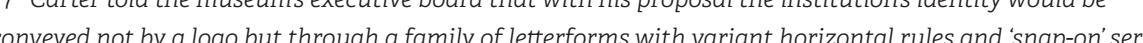
conveyed not by a logo but through a family of letterforms with variant horizontal rules and 'snap--on' serits
- themselves characters in the font that would transform a single, simple typefacce into polyphonic voice" (cuLLEN, 2001:93).

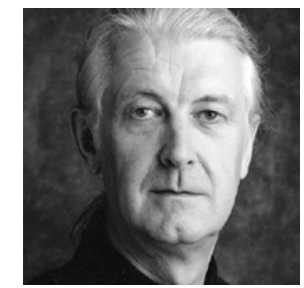

Matthew Carter Nasceu em Londres no ano de 1937, filho de Harry Carter, um tipógrafo, designer de livros e historiador de tipografia. Trabalhou nas type foundries Enschedé e Mergenthaler Linotype de Nova York. Sua carreira tem traspassado os períodos dos tipos móveis, fotocomposição e fontes digitais.

Em 1981, criou a fundidora de tipos digitais Bitstream Inc. em Cambridge, Massachusetts, juntamente com Mike Parker, Cherie Cone e Robert Friedman considerada a responsável pela democratização da tipografia para o desktop publishing. Em 1991, associou-se com Cherie Cone para formar a Carter \& Cone Type. É responsável pela criação de tipografias memoráveis como Verdan Georgia, Sophia, Walker, Shelley Scrip Snell Roundhand, Miller, Mantinia, Galliard, Bell Centennial, Big Caslon e Yale, entre muitas outras. Foi o ganhador do prêmio do Type Directors Club (TDC) de 1997, honraria para aqueles que contribuiram significativamente para a vida, arte e oficio da tipografia (EXE MAGAZINE, 1993, s.n.; YALE UNIVERSITY, s.d./. 
ao entenderem que a própria natureza multiforme da fonte exigia isso. Em 2010, a tipografia Walker foi incorporada à coleção do Museu de Arte Moderna de Nova York, MoMA, no departamento de Arte e Arquitetura sob o registro de número 1069.2010.

4.5.1 O Walker Art Center_Em 1879, a modesta galeria de arte do barão madeireiro norte-americano Thomas Barlow Walker era o único lugar que reunia algumas pinturas na cidade de Minneapolis, estado de Minnesota Estados Unidos. Fundada oficialmente em 1927 como a primeira galeria de arte pública do meio oeste superior do país, atualmente é um respeitado centro de arte contemporânea. A partir dos anos 1940, foi um dos primeiros centros de arte a privilegiar a arte moderna, comprovado pela aquisição de obras como Picasso, Giacometti, Moore, o que lhe valeu uma reputação de um polo transmissor da arte contemporânea e modelo exemplar para instituições do mundo inteiro (HYLAND, KING, 2006:167). O Walker Art Center é um museu de artes com uma abordagem global, multidisciplinar e diversificada para a criação, apresentação, interpretação e preservação da arte. Seus programas institucionais, de nível internacional, mantêm o compromisso de exibir os principais artistas visuais, teatrais e de mídia do mundo. Desde a sua criação, o Walker tem se posicionado para o avanço 20 da arte contemporânea e, ultimamente, tem feito contribuições significativas para a comunidade do design gráfico, como uma associação dedicada a impulsionar a carreira de recém-graduados, cursos, um blog, publicação de livros eartigos, além de exposições (WALKER ART CENTER,s.d.). Concentrado nas artes visuais, no espetáculo e nas mídias do nosso tempo, o espaço aglutina a expressão criativa de artistas contemporâneos e de um público ativamente engajado.

A vocação multicultural fica bem representada no slogan repetido en seus calendários mensais: "Open to interpretations. Closed on Mondays" (CULLEN, 2001:93). Além de suas coleções permanentes, exposições tempo- 3 rárias são acompanhadas de espetáculos de dança, teatro, concertos, projeções de filmes e atividades pedagógicas em oficinas e eventos performáticos com John Cage, Phillip Glass, Grupo Fluxus, Laurie Anderson, Jean-Luc Godard e Jorge Luiz Borges. Em local adjacente, está o Minneapolis Sculpture Garden, um dos maiores parques urbanos de esculturas do país, inaugurado em 1988. Em meados de 1995, a tipografia Walker de Carter foi implantada no novo projeto gráfico. Em fevereiro de 2004 o museu fechou as portas por um ano para obras de reforma e expansão. Reabriu em abril de 2005, em novo endereço projetado pelo escritório de arquitetura Herzog \& de Meuron, dotado de espaços expositivos suplementares e teatro, novos ambientes destinados aos

05 visitantes como um restaurante, lojas e estacionamento subterrâneo. Um dos ambientes importantes é uma grande praça de convivência social, para eventos programados ou espontâneos. Durante o ano em que ficou fechada, a instituição organizou uma série de exposições e eventos sob o título genérico de Walker Without Walls (HYLAND, KING, 2006:167). Essa

10 série de eventos se desenrolou em várias localidades da cidade, desde o jardim de esculturas até regiões mais periféricas. Durante esse evento, variações da fonte foram trabalhadas pelo diretor do departamento de design do WAC e empregadas em um sistema de identidade, igualmente fundamentado na tipografia, que se comportou como o elemento identificador que neutralizava a dispersão dos eventos.

4.5.2 A tipografia Walker e a Identidade Visual de 1995 Como seu histórico demonstra o WAc tem um comprometimento natural com a arte e o design contemporâneo. A estética modernista do Estilo Interna20 cional dos anos 1950, baseada nos tipos sem serifa, grade construtiva ortogonal e composição assimétrica que preserva grandes espaços brancos era a linguagem predominante para dialogar com seu público nos variados meios de comunicação. Até os anos 1990, o departamento de design foi coordenado por Mildred Friedman, que estabeleceu o programa de

25 identidade gráfica descrito por ela como um estilo internacional inabaláve, em que predominavam as tipografias Franklin Gothic e News Gothic dispostas hierarquicamente em uma malha gráfica racional que primava pela fácil legibilidade (KING, 1999, s.n.). Segundo Cullen (2001:93) esse conceito acompanhava a postura da maioria das instituições

30 corporativas ou culturais mais preocupadas em manter uma imagem estável e imutável. Friedman foi sucedida por Laurie Haycock Makela (coordenação de 1991-1996) que buscou se afastar do rigor modernista. A palheta tipográfica foi variada para as OCRB, DIN e Carmela, entre outras. Entretanto, essa diversidade não atendia ao problema mais urgente de 35 fortalecer tipograficamente a identidade visual.

Decidiu-se por um caminho completamente novo. Cullen (2001) relata que Makela, juntamente com a equipe responsável pelo escritório 


\section{$\bar{c} \bar{N} \bar{N} c \tau$ T每T Nin 疍} "Connect to the New" Haycock Makela and Matt Eller. em com a estética modernista ao cionalismo e a experimentação, optando por uma linguagem gráfica que contrariasse a estética modernista e que fosse mais próxima do pós-modernismo norte-americano dos anos 1980-1990, período em que Laurie e seu marido, P. Scott Makela, viveram intensamente. Essa nova identidade se tornaria a nova voz da instituição e, para isso necessitaria ser flexível, menos autoritária, expressiva e pluralista. Entre DES I G N os componentes necessários para a tarefa, uma tipografia exclusiva e os componentes necessários para a tarefa, uma tipografia exclusiva e
que carregasse o espírito das mudanças almejadas, era uma prioridade (CULLEN, 2001:94).

Makela convidou Matthew Carter para conduzir essa missão. Eles já haviam trabalhado juntos na edição de 1993 do periódico Design Quarterly e nele, escreveu o artigo Three New Faces em que apresenta as fontes Quartet de Zuzana Licko, OutWest de Edward Fella e Sophia de Matthew Carter (FIGURA 175). Segundo Margaret Re (2002), Makela delineia nesse artigo a tese de que "formas maneiristas individualizadas poderiam avivar a linguagem" (RE, 2002:24) por oferecer aos designers de tipos a oportunidade de humanizar e ornamentar a forma das letras, ideia que guiaria o projeto da Walker. Desde as primeiras suposições e caminhos possíveis para o projeto, ganhou força a noção de que um dos elementos componentes do sistema de identidade passaria ao papel de protagonista absoluto - a tipografia seria a própria identidade, conforme Makela lembra: “Começamos com a ideia de que uma tipografia poderia ser uma identidade — uma fonte em vez de um logotipo — que percorreria todo o sistema como sangue nas veias" (CULLEN, 2001:94-tradução minha $a^{78}$ ).

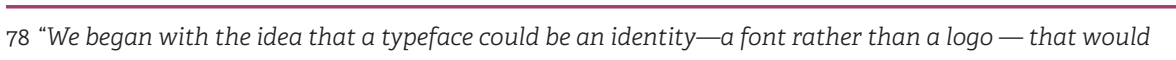

run through the system like blood" (CULLEN, 2001:94.
De acordo com Cullen (2001:94) e Re (2002:25), Carter prontamente aceitou o trabalho, mais pelo desafio e liberdade que estava implícito do que pelo retorno financeiro. Estava mais interessado na possibilidade de criar uma tipografia que exerceria a função prioritária de grande o5 visibilidade, e não um papel secundário no sistema de suporte de uma marca. Ainda, o projeto contou com a participação da diretora do museu, Kathy Halbriech cuja inteligência e experiência nas artes Carter admira muito. Outro motivo que o agradou foi que o desenvolvimento do projeto ocorreria dentro de um ambiente profissional de designers que poderiam

o testar as opções em situações e em tempo real, um verdadeiro laboratório que favoreceu a troca de experiências e surgimento de novas alternativas de uso que não foram previstas, algo novo para o experiente designer.

O trabalho se desenrolou à distância por meio de faxes, correios telefone, ele em Boston e a equipe de designers do WAC em Minneapolis.

15 Carter começou com três ideias (CULLEN, 2001:95), todas maiúsculas e sem serifas, um esqueleto básico a que chamou de "vanilla state" (RE, 2002:25). As duas primeiras opções, que previam letras maiúsculas e minúsculas, chamadas de Walker Sans e Vineland, foram consideradas informais demais e que a primeira já experimentava a opção de serifas. A terceira

zo opção, uma variação da Vineland apenas em maiúsculas, se tornaria a base para a Walker. As proporções e peso das letras foram equilibrados para acompanharem a fonte DiN que seria usada nos textos menores e como ponto de contraste. Em uma delas, explorou a noção de serifas avulsas que foram tratadas como caracteres separados, o que mais tarde chamaria

25 de snap-on serifs, "serifas de acoplar", ou seja, serifas multiformes que podem ser anexadas ou removidas em qualquer haste vertical das letras, inclusive serifas diferentes em um único caractere, conforme o contexto das palavras ou do design geral do texto. Essa particularidade da fonte foi descrita por Carter em entrevista à Phyllis Hoffmann (1999):

...] a essência do projeto está em um conjunto bastante simples de maiúsculas sem serifas, sem letras minúsculas, somente utilizadas para tamanhos grandes, para os títulos. Apesar deles a usarem em tamanhos relativamente pequenos, tem apenas maiúsculas e algarismos. Na fonte, acrescentei o que viemos a chamar de serifas snap on, em vez de as serifas serem parte integrante da forma das letras, como ocorre em outro tipo de letra serifada, obviamente. Eu as fiz como caracteres distintos. Fiz diferentes 
tipos de serifas. Algumas grossas, outras mais finas, as diagonais, serifas slab e serifas curvas. Há cinco ou seis estilos diferentes de serifa nessa fonte. Criei uma maneira de poder anexar essas serifas do teclado para as letras (HOFFMAN, 1999:161-162 - tradução minha ${ }^{79}$ ).

Em uma das muitas mensagens por meio de faxes, Carter reporta a Makela o andamento do trabalho. Nessa mensagem, composta de cinco páginas, Carter concorda que a fonte deve assumir um caráter mais "monumental" e fica satisfeito com a boa aceitação da ideia, ainda em fase de testes, das serifas snap on ao dizer: "[...] elas fornecem uma maneira de diferenciar a tipografia e dar-lhe alguma variabilidade - um equivalente tipográfico da inflexão vocal que você [Makela] menciona" (FIGURA 176). Entretanto, ele alerta para as dificuldades para encaixar as

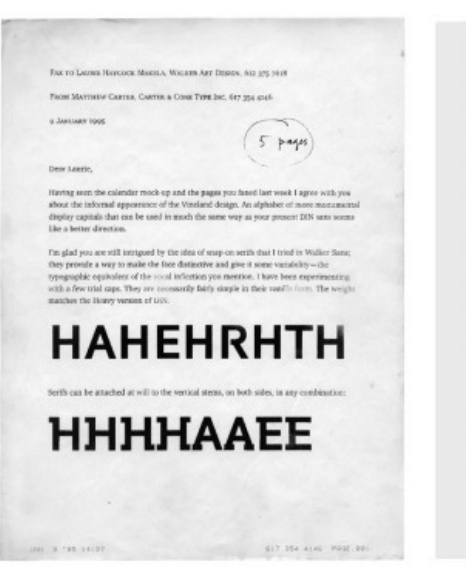

FIGURA 176_Faxes de 9 de Janeiro de 1995 de Matthew Carter para a Makela sobre o andamento do design

da tipografia.

\section{ABCDEFGHIJKLMNO} PQRSTUVWXYZ

НH H H

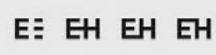

WALKER

WALKER-ITALIC

WALKER-UNDER

WALKER-BOTH

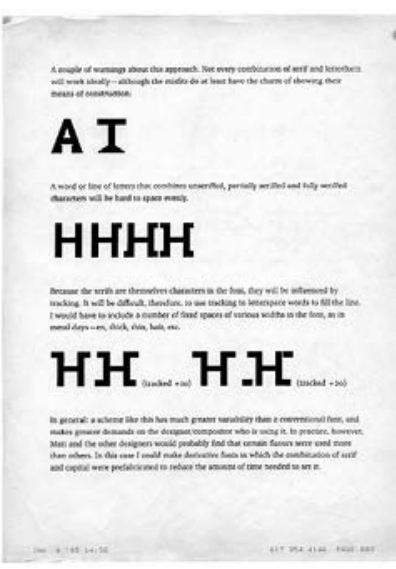
formando um trilho. serifas em algumas letras e de espaçamento uniforme, o que exigirá uma atenção maior por parte do designer que a manipular. Na página quatro dos faxes, o designer apresenta a ideia das barras sobre e sob as letras,

Os recursos tecnológicos que deram sentido à fonte Walker são decorrentes de outras duas experiências de Carter. No portfólio de tipografias realizadas pelo designer, destacam-se designs interpretativos

79 "I... the heart of the design is a rather plain set of sans serif capitals, it has no lowercase, it is only used

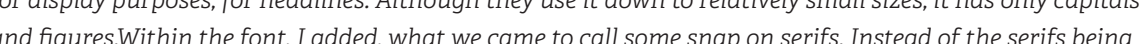
an integral part of the letterform as they are in every other serif typeface, obviously. I made them separate characters. I made different kinds of serifs. I made thick ones, and thin ones and diagonal ones, and slab serifs and curved serifs. There are five or six different flavors of serif in this font. I devised a way of being able to attach these seriff from the key-board to the letterforms" "HOFFMA, 1999:161-162]. de modelos históricos, como as releituras de tipos clássicos como as suas ITC Galliard (Granjon, Garamond), Big Caslon e Mantinia, ou projetos com demandas técnicas rigorosas como a Verdana, Georgia, Miller Text e Bell Centennial. Entretanto, projetos mais experimentais que dialogam

o5 com a linguagem tipográfica são raros na sua produção. Nessa perspectiva Carter desenhou DeFace para a revista Fuse 18 de 1998 (FIGURA 177). A fonte, descrita como "autovandalizada", é uma reflexão baseada na perenidade das letras esculpidas em monumentos públicos, supostamente executadas para perdurar no tempo, mas que são sobrepostas por graffitis e 1. pixações destrutivas. Os principais caracteres são capitulares lapidares em que cada letra tem um graffiti associado que se sobrepõe às letras seguintes corrompendo seu aspecto natural. Dependendo da forma e extensão do texto, o graffiti pode "vandalizar" as maiúsculas ou ele próprio criando o aspecto de um palimpsesto em que se identificam letras individualmente mas totalmente incompreensíveis no conjunto (BRODY; WOZENCROFT, 2012:326). Uma outra experiência foi a fonte Devanagari par a escrita Hindi (Linotype ${ }^{\odot}$ ). As vogais nesse idioma se comportam diferentemente de acordo com sua função na palavra, podendo ser posicionadas acima, abaixo ou ao lado das consoantes. Aproveitando tecnolo20 gias desenvolvidas pela type foundry (V.I.P. System), as vogais podiam ser aplicadas de modo correto por comandos ajustados do teclado. Essa experiência influenciou completamente o resultado da Walker ( $\mathrm{RE}$, 2002:25).

A maioria das serifas foi inspirada nas tipografias egipcianas ${ }^{80}$, de serifas quadradas, que surgiram durante a Revolução Industrial

25 sobretudo na Inglaterra vitoriana, período em que os tipos ganharam robustez e impacto visual para uso em tamanhos muito grandes, como nos cartazes, e cuja experimentação a Walker está relacionada (Ibid.). A ideia correspondia ao conceito de inflexão, mutabilidade e diferentes tons de voz. Ao mesmo tempo em que as serifas são familiares e aproximam o leitor, a Walker impõe sua mensagem inovadora ao possibilitar serifas múltiplas em uma mesma palavra ou frase, referenciando a multiplicidade de "vozes" em um mesmo texto.

A fonte Walker foi gerada no formato Type 1 e funciona apenas em sistemas Apple Macintosh ${ }^{\odot}$. Como a tecnologia OpenType, cujo meca35 nismo permite inúmeras variações de estilos e caracteres alternativos 80 Serifas egipcianass: serifas do tipo slab, quadradas e grossas, da mesma espessura das hastes com ou sen
junçăo curva. Como nos tipos Clarendon. Memphis, Archer Rockwell, por exemplo (cf Glossário Visuall.

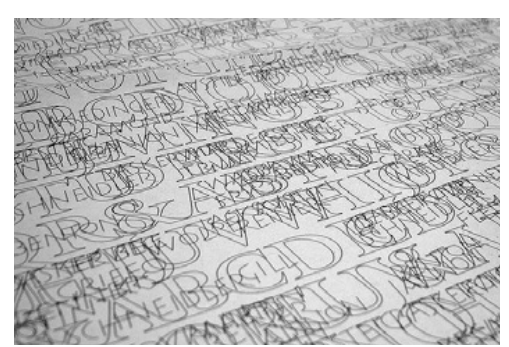
FIGURA 177_Detalhe do carta da fonte DeFace de M. Carter, Descrita pelo próprio designer como "autovandalizada" $e$ inspirada em inscriçöes lapida em cemitérios eedificios. 
responsivos ao contexto, só foi efetivamente lançada após o ano de 1996, a fonte não tem uma codificação especial para funcionar. Na verdade o mecanismo é bastante simples: os caracteres alternativos e seus elementos snap on ocupam as células reservadas aos caracteres pouco usados como os ' $\mathrm{i}^{231} \notin \phi^{\circ} \mathrm{o}$ a $-\S^{\prime}$. Para que as serifas e traços se encaixem corretamente nas hastes das letras, seu espaçamento foi ajustado e o valo métrico de sua largura reduzido a zero. Assim, ao digitar a serifa uma letra, a somatória de seus espaçamentos resulta no encaixe ideal.

O conjunto de serifas é aplicado usando as teclas SHIF+OPTION e OPTION, seguidos de um número de 1 a o, cuja combinação altera o formato da serifa e sua posição no caractere. Os elementos snap on são formados por cinco serifas e dois tipos de traços: (1) serifa quadrada unilateral apenas em um dos lados da haste; (2) serifa quadrada bilateral, arremata

FIGURA 178_Mecanismo da aplicaşão independente das serifa Ocomando Shift+Option controla controla a posição inferior: meros impares controlam 0 lado esquerdo os pare olado direito das letras.

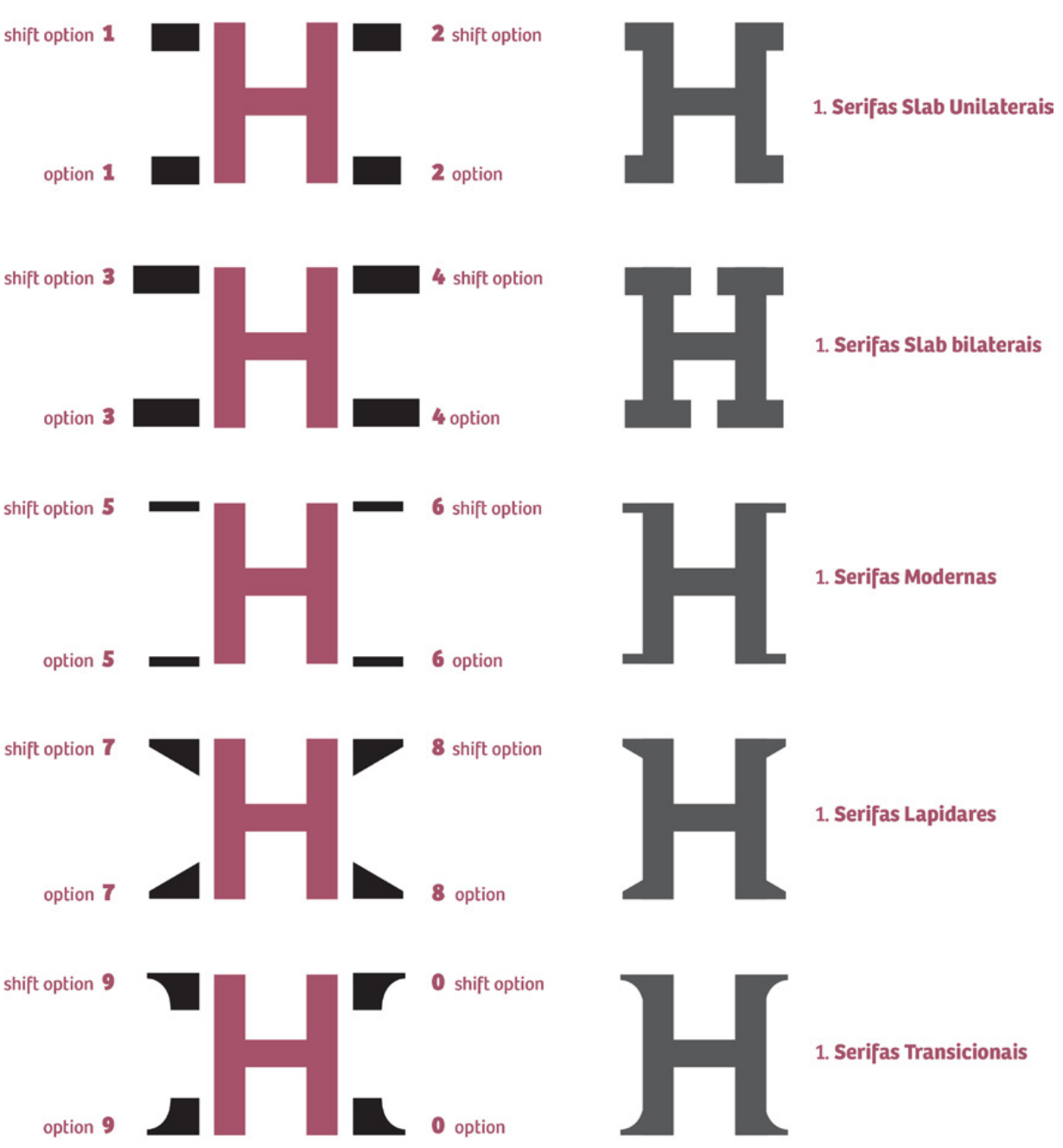

os dois lados da haste: (3) serifa moderna unilateral e mais fina: (4) serifa lapidar, triangular e unilateral; (5) serifa transicional, com junção curva entre a serifa e a haste (FIGURA 178): e (6) traços, além das serifas, traços horizontais que funcionam como ligaturas são aplicados da mesma maneira e são formados por um traço horizontal superior (curto), um traço na linha média (um pouco mais longo) e outro traço curto na parte inferior. Estes usam o sinal '=' como base, acrescentados das combinações com SHIFT-OPTION e OPTION (FIGURA 179); (7) barras, além das serifas e traços, é possível aplicar barras ou linhas inteiras na parte superio inferior ou em ambas partes da letra, o que Carter chamou de wash lines. São aplicadas alterando os estilos no menu da fonte, convencionalment reservado para bold, itálico, etc., com as referências regular (sem barra), over, under e both. Esse recurso pode criar uma linha contínua que interliga as letras de forma articulada na parte superior que "pendura" ou "apoia" todo o texto, linhas inferiores que "assentam" o texto ou linhas duplas que "aprisionam" o texto (FIGURA 180).

HAMBURGEFONTSIV HAMBURGEFONTSIV HAMBURGEFONTSIV HAMBURGEFONTSIV HAMBURGEFONTSIV HAMBURGEFONTSIV HAMBURGEFONTSIV Wrapte de haixo, a aplicação do mesmo recurso na versão iólica. HAMBURGEFONTSIV
$\mathrm{HTH} \mathrm{HH}$

1.

政 t

HGURA 179-Mecanismo de aplicação
dos tracos de ligacâao:funciona do mesmo modo que as serifas, acrescentando o comando $=$ "que insere o traço NHA 1: sem barras Regular INHA 2: barra superior 'Over', NHA 3: barra inferior Under;' NHA 4: barra superior e inferior Both'; 
Margaret Re (2002) observa que o objetivo das barras e traços vão além dos propósitos que coincidem com as expectativas do novo design:

À primeira vista, as barras são puramente decorativas; elas não fornecem ao usuário informaçōes essenciais. Mas um exame mais atento revela que as barras auxiliam o usuário na organização do texto para leitura porque, quando os designers experimentam a Walker tipograficamente variando o tamanho das letras nas palavras, pela sobreposição letras ou quebra do texto, as barras proporcionam uma trilha para o leitor seguir (RE, 2002:26 - tradução minha ${ }^{81}$ ).

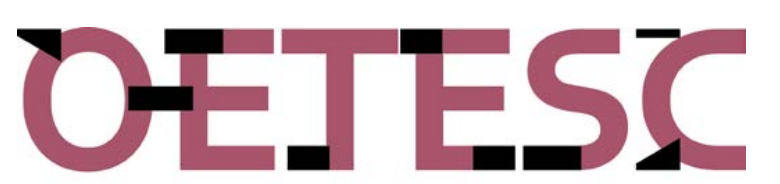

Uma aplicação prática desses recursos possibilit composições controladas para qualquer palavra (FIGURA 181) ou como pode ser visto no cartaz do designer japonês Kouga Hirano, que trabalha com os recursos das barras, traços e

OEJESC serifas quadradas da fonte Walker (FIGURA 182).

Durante o processo de criação, Carter trocou mensaFIGURA 181_Exemplo de aplicação de serifas differentes em uma messma incomuns, como na curva do ' 0 , C'. etilístico fortequeauxilaria a alnharos textos comilustraços eo figuras. Na página 3 dos faxes que enviou a ela (FIGURA 176), também alertou para o fato de que nem todas as combinações entre serifas e letras funcionariam de maneira ideal, como serifas aplicadas em hastes diagonais, DP por exemplo (FIGURA 183), mas contornou o problema entendendo que o Wद्र desencaixe teria seu "charme" ao revelar sua construção. Como as serifas foram concebidas como caracteres da fonte, esse efeito poderia ainda ser exacerbado pela manipulação dos espaçamentos.

A-O- $-\frac{2}{N}$ TU. MG DD EFP $P$ R:- $\frac{\mathrm{D}}{\mathrm{S}}$

Cullen (2001) concorda que a melhor e mais sintética definição da Walker vem do próprio designer, para quem os traços, barras e serifas snap-on foram pensados como acessórios que "vestem" a tipografia: “Eu a vejo mais ou menos como manequins de vitrina de loja, com uma boa estrutura óssea em que se podem pendurar diferentes tipos de roupas" (CULLEN, 2001:95 - tradução minha ${ }^{82}$ ) Hirano, de 1997, para exposição em homeSpaceem Tokio, Japão.
O impacto da fonte na identidade visual evidencia a flexibilidade e fluidez do texto, além do caráter multifacetado e dinâmico que a instituição pretendia manifestar. Esse efeito foi multiplicado pela experimentação compulsiva dos designers que haviam participado do desenvolvimento e

5 pelo tratamento gráfico do design das peças, ao explorarem enfaticament composições tipográficas ousadas em títulos e em combinações criativas com imagens. Os materiais de divulgação de eventos, muitas vezes, trazem imagens desconcertantes, irônicas ou enigmáticas acompanhadas por textos compostos de maneira igualmente expressiva e integrados ao conteúdo das imagens (FIGURA 184). Qualquer resquício da estética modernista que prevaleceu por anos deu lugar a uma linguagem gráfica com personalidade, que pretende se comunicar diretamente com os diferentes públicos e dar coerência visual à variedade de artistas e eventos internacionais que o museu promove. A tipografia e suas múltiplas possibilidades, propiciam

15 variantes expressivas e entonações que contribuem com a representação visual das mensagens, em que predominam a cor preta nos títulos e textos, imagens monocromáticas e uma austeridade equilibrada no uso das cores.

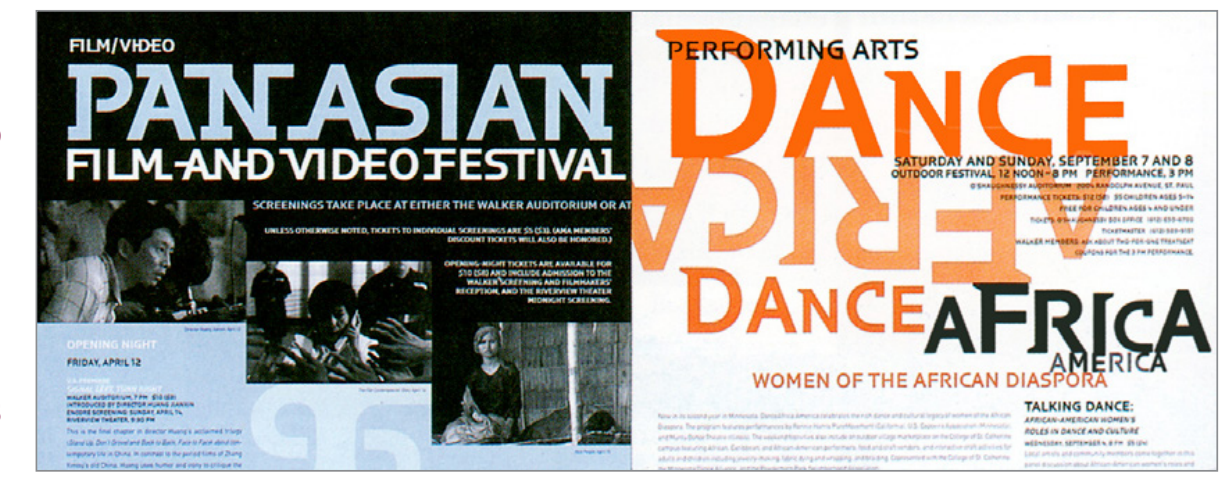

Walker é um conceito, não apenas uma fonte. O designer brasileir que participou da equipe que construiu a fonte juntamente com Matthew Carter, Santiago Piedrafita declarou: "Você não está digitando com uma o fonte, a fonte é criada durante o processo de criar a peça" (Ibid.:96). A fonte não apenas cumpre seu papel em conduzir a identidade da instituição mesmo em mensagens gráficas curtas, como também se adapta ao modelo estético pós-modernista disseminado por todo o material gráfico da instituição. A expressão da palavra é literalmente construída por serifas e traços da mesma maneira que pode ser desconstruída, criando camadas de interpretações diferentes, um campo aberto para todo tipo de experimentação gráfica do design (FIGURA 185).

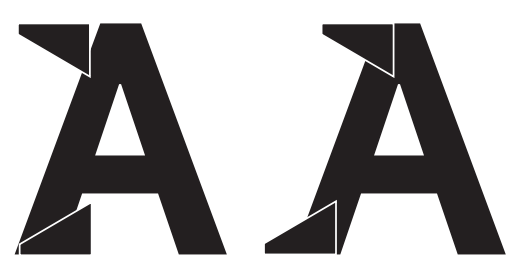

FigURA 183_Problemas de posicionamento da serifa com hastes diagonais. Do lado direito a correçãof feita por ajuste de caractere "A"

FIGURA 184_Ao lado, exemplos do uso da fonte Walker em composiçōes para o calendário mensal de eventos, 1995-1996.

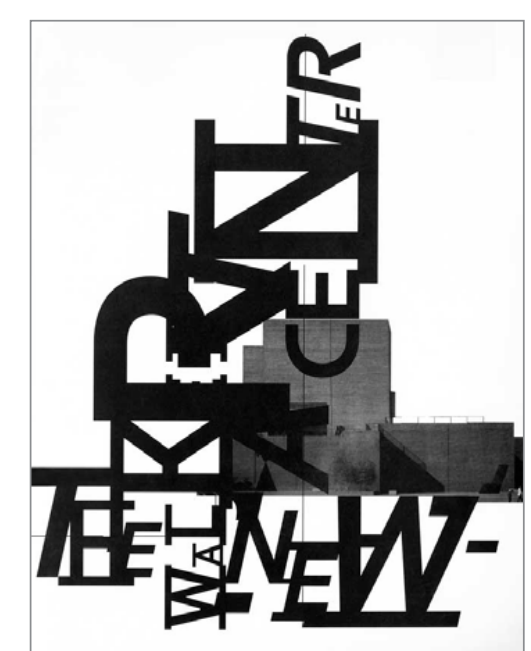

FIGURA 185_Acima, ilustração tipográfica. de Matthew Cartee Matt Eller, 1995. 
45.2.1 Principais aspectos anatômicos da fonte Walker_Walker é uma tipografia unicamente em maiúsculas, com uma estrutura básica sem serifas e com possibilidade de aplicação de serifas independentes ede estilos diferentes, para uso em títulos. É composta por duas versões básicas: Walker Regular, com variantes de estilos sem barra, com barra superior, com barra inferior e com barra dupla e Walker Italic, com as mesmas variantes de estilo da versão normal. Tem caracteres alternativos para as letras 'C, K, R, S, \&', ligaturas e setas (FIGURA 187).

\section{ABCDEFGHIJK VWXYZ123456}

FIGURA 186_Caracteres básicos da Walker, sem serifas.

\section{$\rightarrow$ CKRSQNE}

FIGURA 187_Caracteres alternativos, com prolongamentos, serifas verticais, incluindo setas de direção para composição de sinalização.

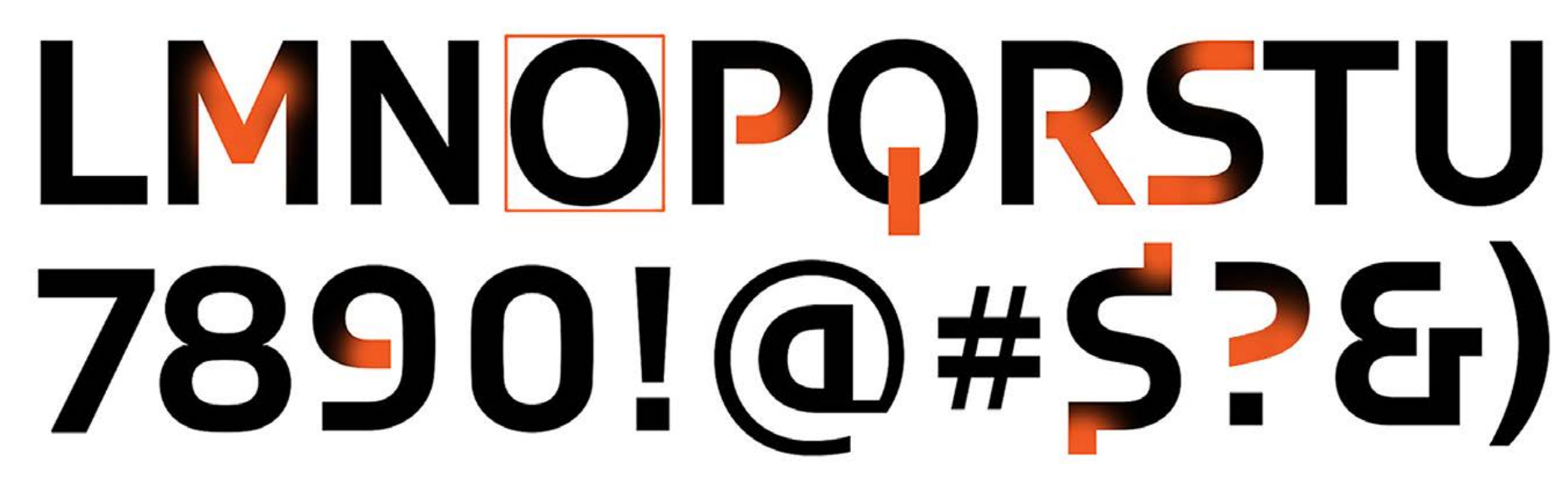

Caracteres-chave:

C, G, J, S, com arcos superiores e inferiores totalmente horizontais; G, sem espora, com pescoço em quina;

K, com junção do braço e perna conectados a uma barra horizontal;

$\mathbf{M}$, com vértice elevado e terminal reto;

B, $\mathbf{P}, \mathbf{R}$, com bojo aberto; ' $\mathbf{R}$ ' com perna reta e diagonal;

Q, com cauda reta e vertical posicionada ao centro;

S, com espinha quase plana; curvas dos algarismos:

0. 6. 8, 9, tem proporção mais condensada e formas mais

retangulares; arcos do ' 6 ' e ' 9 ' terminam em reta plana;

4, formado exclusivamente por retas verticais e

horizontais e aberto na parte superior; o sinal monetário

$\mathbf{S}$ tem traço vertical curto nas extremidades das curvas.

serifas snap on pode

transicionais;

Atributos decorativos são formados por traços horizontais e podem

tanto unir letras em várias posições como interligar uma palavra inteira 35

pela parte superior, inferior ou ambas.

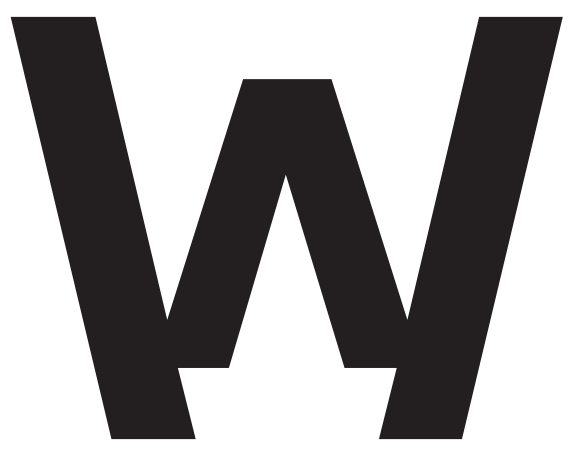

FIGURA 188_Glifo alternativo para o caractere ' $W$ ' incluído na fonte como opção para uso no logotipo.
Além dos caracteres especiais citados anteriormente, uma opção alternativa para o glifo do caractere ' $W$ ' foi incluída para compor o logotipo, ideia que não foi muito aproveitada (FIGURA 188). 
WALKER

WITHOUT WALLS

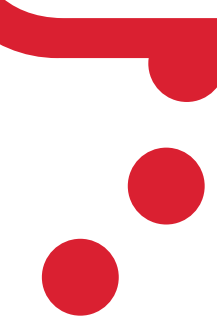

FIGURA 189_Marca composta por logotipo, em Walker, e símbolo com os sinais da nova linguagem gráfica.
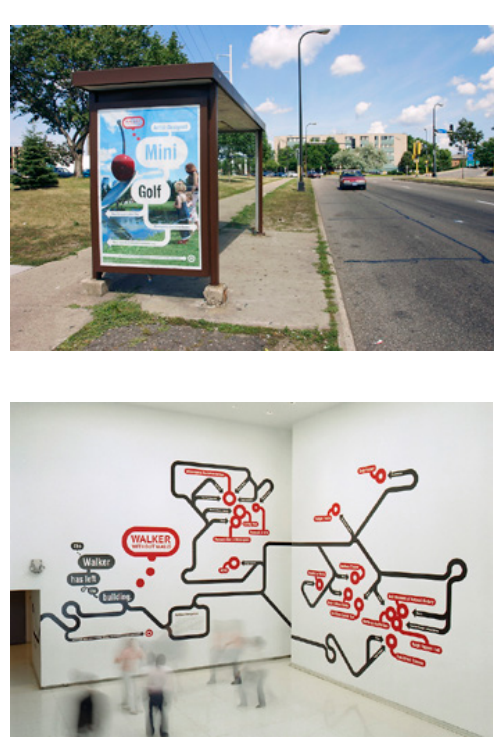

FIGURA 190_Em cima, cartaz e ponto de onibus.

FIGURA 191_Embaixo, espaço interno com a aplicação de elementos gráficos que componen un mapa conceitual do es ovais, linhas curvas e setas.

FIGURA 192_Ao lado, aplicaçăa da identidade visual nas calçadas. e veículos.
4.5.3 Walker Expanded e a Identidade Visual de 2005__ o grande evento expositivo Walker Without Walls, que aconteceu entre fevereiro de 2004 e fevereiro de 2005, período em que o museu esteve fechado para reformas, exigiu que a nova equipe do departamento de Design, agora coordenado por Andrew Blauvelt, criasse uma campanha para manter a visibilidade do WAC e sua programação. $O$ briefing foi novamente pautado pela mudança na relação com o público, uma relação que agora não dependia da vontade das pessoas visitarem um local, pois as obras estariam no ambiente cotidiano do público. A comunicação deveria responder a essa delicada questão e ser compatível com os futuros espaços arquitetônicos do museu reformado. Portanto, o projeto visual precisaria se adaptar aos espaços públicos como placas de rua, postes, mapas, calçadas veículos, pontos de ônibus, em uma variedade de suportes materiais impressos e digitais. Esses sinais incorporados à fonte foram inspirados na linguagem gráfica de sinalizações de rua,jogos de tabuleiro e mapas de localização, formando um conjunto de sinais e pictogramas como setas, linhas curvadas, balões circulares e ovalados para conter textos. Além do logotipo do evento (FIGURA 189), o conceito foi aplicado em peças gráficas como sinalização de espaços exteriores e interiores (FIGURA 190 e 191), veículos e graffitis em calçadas (FIGURA 192).

Se Laurie H. Makela apostou incondicionalmente na força da tipografia como elemento identificador, Blauvelt e sua equipe de designers formada por Chad Kloepfer e Emmet Byrne, preferiram ampliar os recursos tipográficos inaugurados pela Walker para potencializar as outras possibilidades do design. Enquanto o projeto de 1995 explorou intensamente as alternativas compositivas da palavra e do texto baseadas na Walker, em 2004 o design retoma as cores em um organizado sistema gráfico e a identidade se constrói pela articulação de seus elementos.
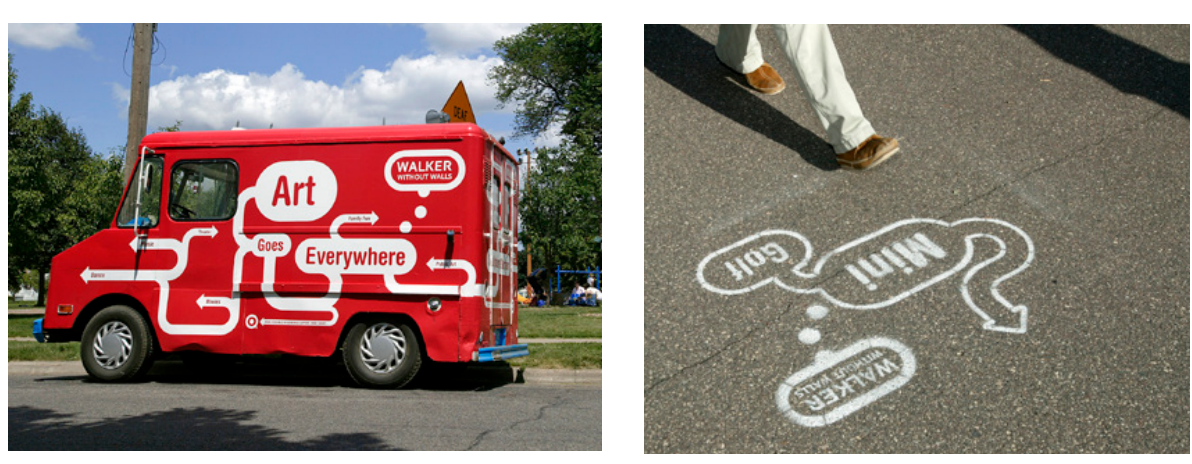

Introduziram a fonte Avenir de Adrian Frutiger para compor os textos secundários e os mais longos e mantiveram a fonte Walker para os títulos e para grafar o nome das entidades do museu, agora empregada em sua versão mais simples, o vanilla state, sem serifas, traços ou barras. As palavras

5 atuavam como sinais de marcação em linhas contínuas de texto (FIGURA 193) intercaladas com sinais que formavam tarjas de padrões gráficos repetidos (FIGURA 194). A ideia era que a fonte tipográfica poderia conter uma série de expressões, ou vocábulos, como o designer preferiu chamar, cada um associado a uma tecla do computador. Os vocábulos construiriam a matriz do "tom de voz" da nova identidade (BLAUVELT; BELL, 2006). O sistema visual é formado por um "pacote de partes" batizado de Walker Expanded, cujos elementos são dispostos em barras de padrões colorido que comportam palavras (vocábulos) em longas tarjas ou "fitas", como

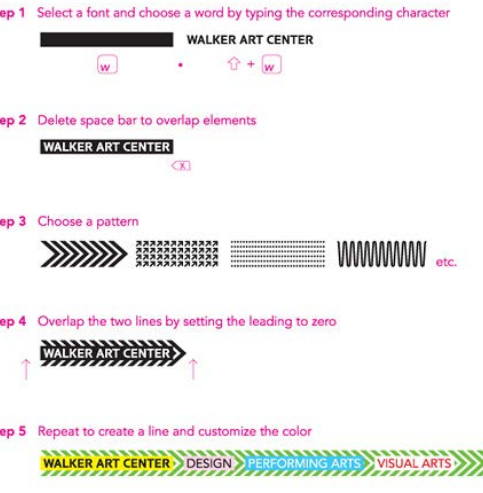
FIGURA 193_Odiagrama exemplifica como as tarjas são formadas. A sequência de digitação é importante para controlar o design desejado.

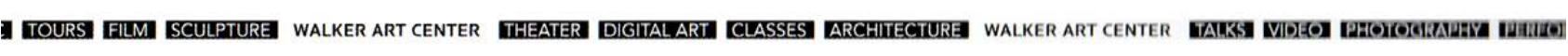

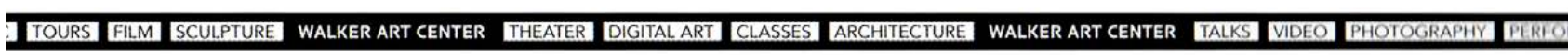

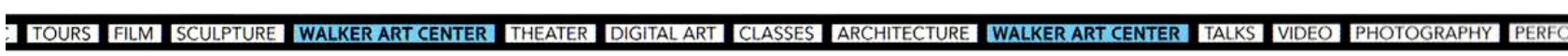

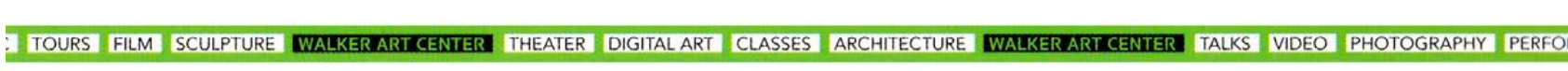

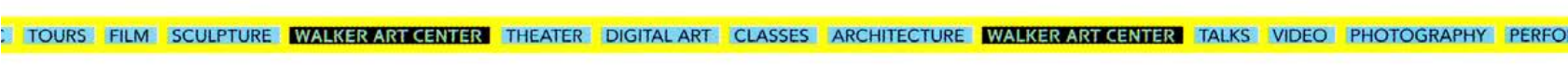

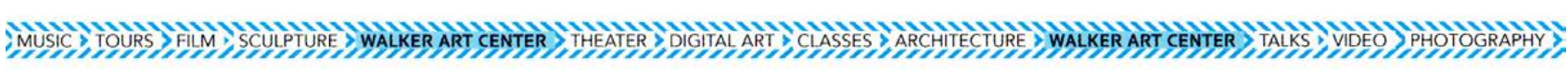

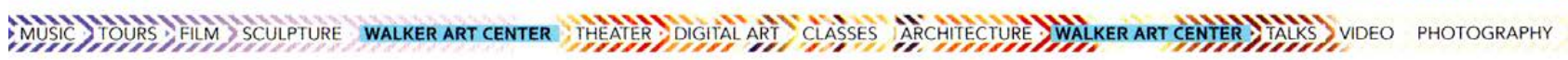

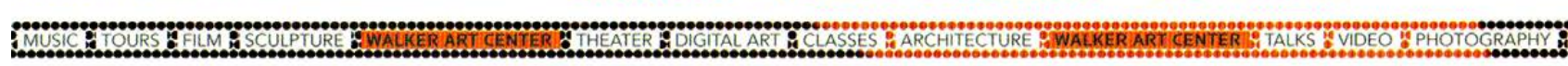

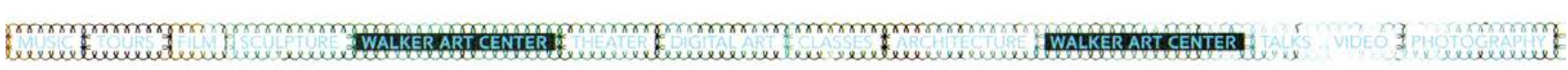

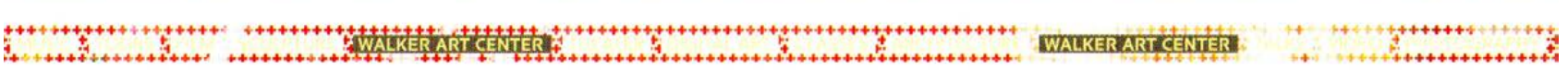

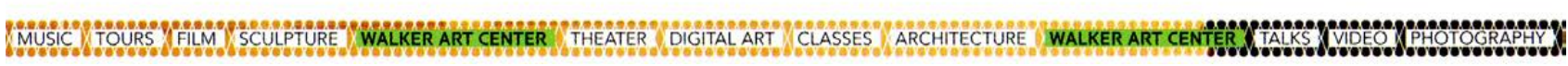

30 Blauvelt se refere. A fonte é uma coleção de palavras inteiras como 'EXHIBITIONS', 'FILM' ou 'PERFORMING ARTS' em vez de letras individuais, assim como a série de sinais gráficos. Todas as disciplinas artísticas, tipos de eventos e setores de lojas estão representadas nos vocábulos. As cores e os elementos gráficos decorativos são introduzidos juntos com 35 as palavras ao lado ou sobre as tarjas. Assim, a identidade pode ter desde uma construção visual mais simples ou sóbria até composições mais complexas e vibrantes.
FIGURA 194_Exemplos de construção das tarjas variando o grau de complexidade e aplicação do padrão cromático ao grafismo ès palavras sempre pretas ou brancas. 
Para que a fonte funcionasse como planejado, Blauvelt recrutou o designer Eric Olson da Process Type Foundry para materializar a ideia em uma fonte digital. Encarada como uma ferramenta, a fonte Walker Expanded aloca palavras no lugar de letras: para escrever a palavra DESIGN, basta pressionar a tecla 'd', para a palavra SCULPTURE, tecla 's' e assim por diante (FIGURA 195).

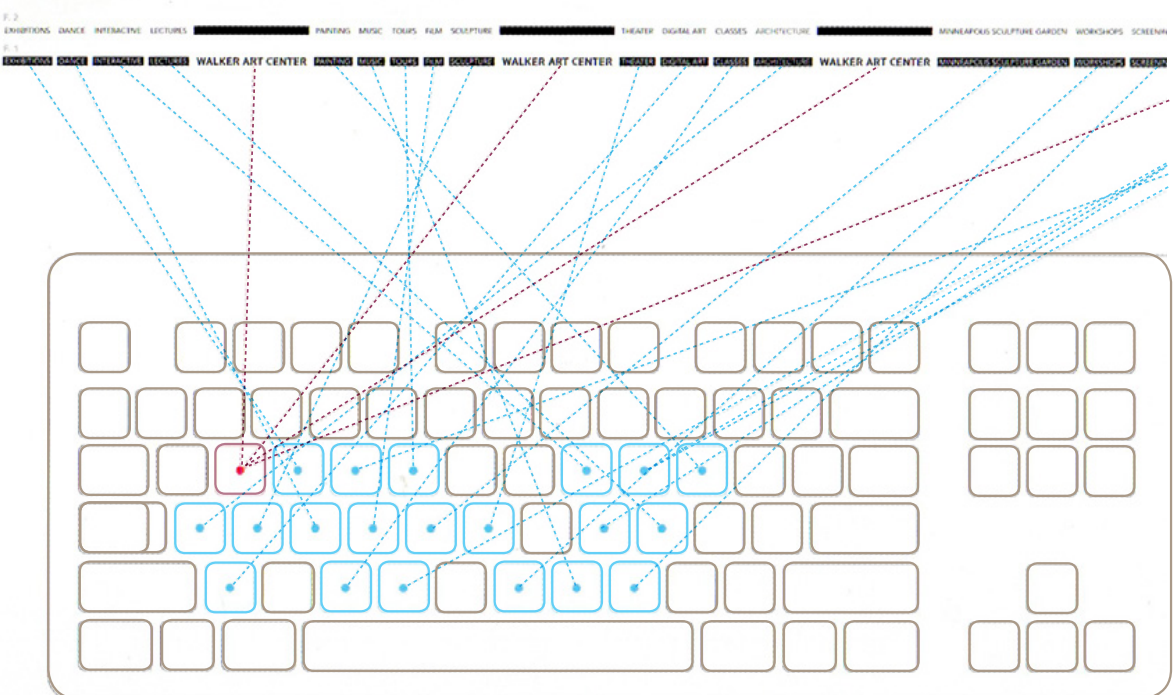

Sequências personalizadas de vocábulos podem ser rapidamente

FIGURA 196_As tarjas são produzidas por 'caracteres gráficos' que correspondem às letras do alfabeto que, pela digitação repetida de continua do grafismo. formadas para comunicar um assunto específico. Os padrões gráficos são originários de elementos gráficos capturados dos ambientes que abrigaram os eventos espalhados pela cidade e da arquitetura da nova sede, e estão alocados no lugar das letras maiúsculas (FIGURA 196). Segundo

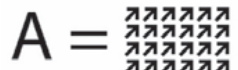 $\mathrm{G}=80889$
$M=\Pi$

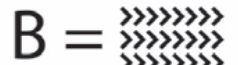
$\mathrm{H}=\ll$
$\mathrm{N}=$
$C=\equiv$
$\mathrm{D}=$
$\mathrm{E}=\||\||||||||$
$\mathrm{I}=$
$\mathrm{O}=$
$\mathrm{J}=$ )ill
$\mathrm{P}=$
$\mathrm{K}=$ IIII
$\mathrm{Q}=$ = UOOW
$\mathrm{F}=\mathrm{s}:$

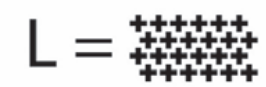
$\mathrm{R}=$ "IIIIIIIII

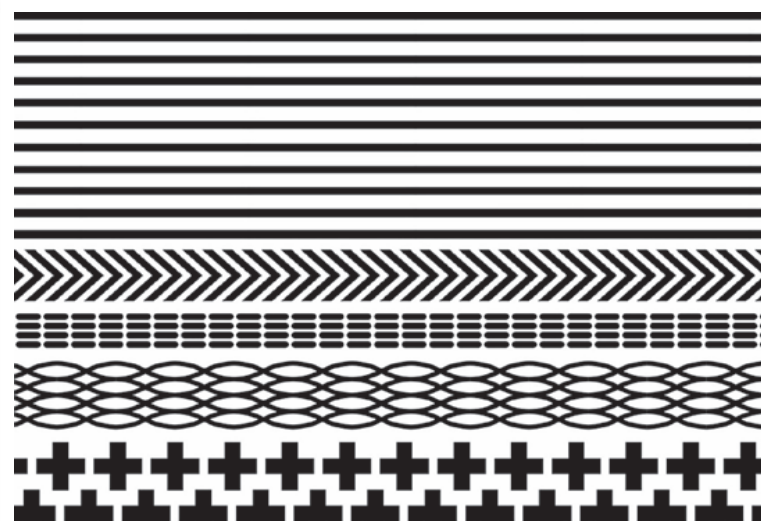

o1 sobrepor exatamentea outras barras ou vocábulos, o que foi alcançado po um trabalho minucioso nos espaçamentos e kernings. O resultado final das tarjas impressiona pela precisão, algo que Olsen julga ter sido muito mais complicado de se conseguir se fosse feito com vetores ou imagens. As 05 possibilidades de combinação de grafismos, vocábulose coresétão grande que a complexidade e multiplicidade de soluções dispensam um manual de identidade para normatizar o sistema, considerando que toda a comunicaçãoé produzida e controlada pela equipe de designers internos do museu.

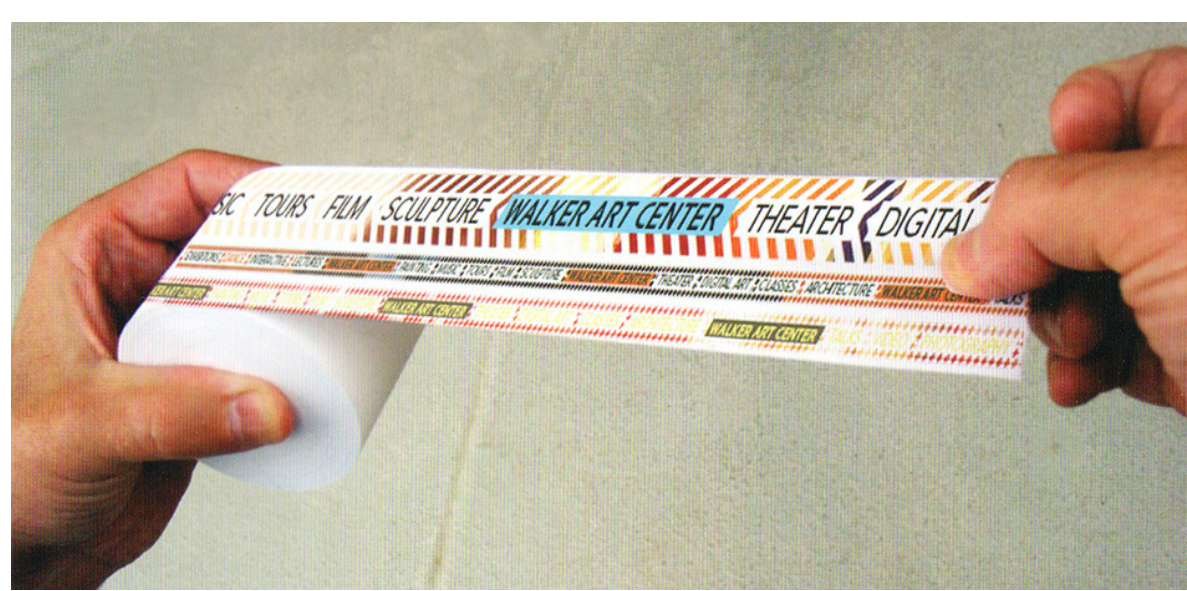

Osistemadaidentidadevisual,completamentebaseadonatipografia Walker Expanded, permite aplicações muito variadas em suportes tamanhos diferentes. A natureza versátil das tarjas levou à ideia de aplicá-la em um rolo de fita adesiva contínua (FIGURA 197) que pudesse ser aplicada em qualquer peça gráfica, em envelopes, cartões, lacre para sacolas e capas de agenda; serve também como área de fundo decorativo ou, se ampliada, em sinalizações de qualquer dimensão. (FIGURAS 198)

A fonte Walker foi usada exclusivamente pelo Walker Art Center por quatro anos, de 1995 a 1999. Após esse período continuou a ser usada pelo museu, mas os direitos legais de propriedade da fonte retornaram 3o para o designer Matthew Carter
FIGURA 197_O Sistema visual das tarjas ampliado para fita adesiva contínua que pode ser rapidamente aplicada em diversas superfíies.
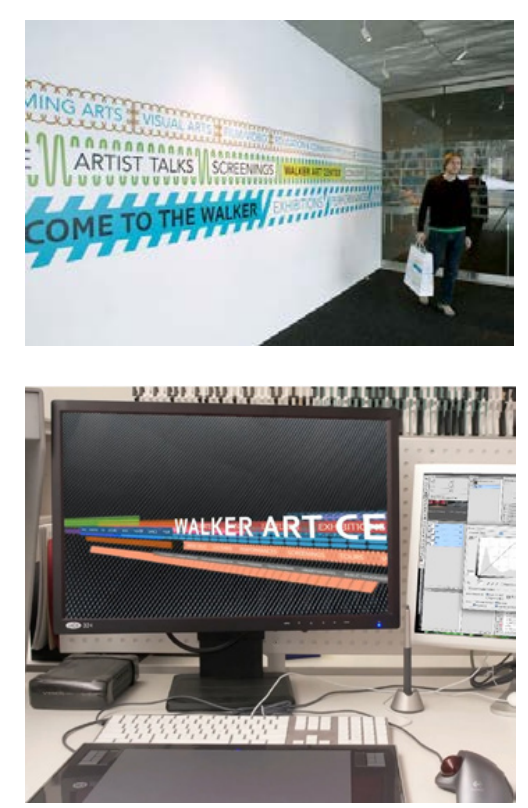

FIGURAS 198_A versatilidade do sistema permite inúmeras aplicaçōes diferentes em diversos suportese ambientes. 

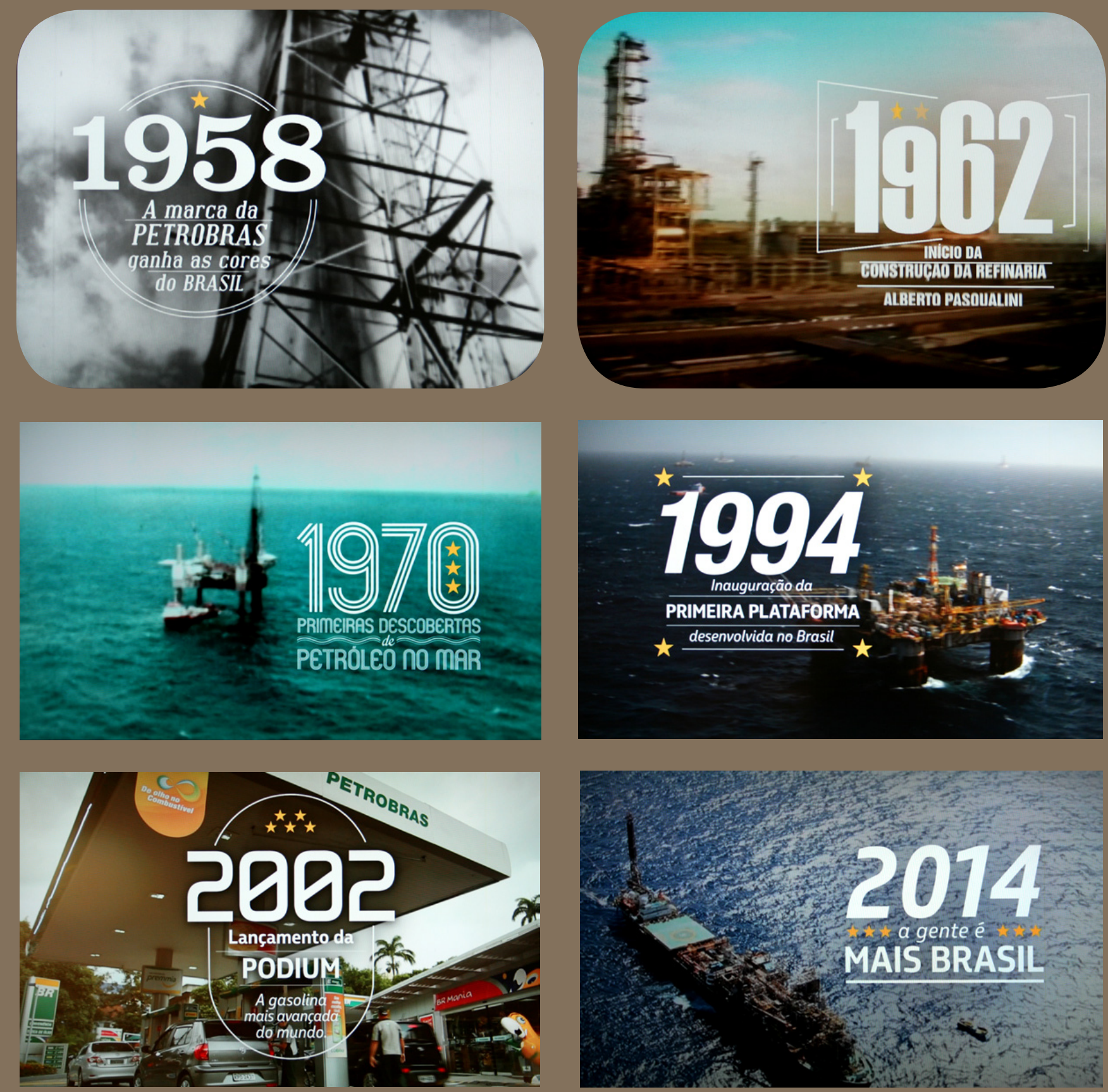

FIGURAS 199_Campanha publicitária. veiculada no inicio de 2014, percorre a historia da Petrobras nos anos em que o Brasil foi campeão mundial das Copas, pontuando cada periodo com tipografias representativas, finalizando o ano de 2014 com a nova Petrobras Sans.
4.6 PeTROBRAS SANS, 2012 _ A fonte Petrobras Sans pode ser considerada a primeira tipografia customizada original, para textos e títulos, feita por brasileiros para uma empresa estatal de porte internacional. A instituição, fundada em 3 de Outubro de 1953 pelo então presidente Getulio Vargas, deu atenção especial ao redesenho de sua marca (FIGURA 200) quando contratou o designer brasileiro Aloísio Magalhães para formular uma síntese visual que estabelecesse uma identidade brasileira, apreendendo a força e o significado da palavra Petrobras e que se consolidasse como um elemento de informação ágil e sintético (SOUZA LEITE, 2003:204). A empresa estatal, de grande visibilidade interna externa, seria pioneira no país ao desenvolver uma $\begin{aligned} \text { FIGURA 200_Em cima, } a & \text { externa, seria pioneira no país ao desenvolver uma } \\ \text { marca criada para } a & \text { identidade visual completa, estruturada como }\end{aligned}$ marca criada para a identidade visual completa, estruturada com Embaixo, a versão vertical Un do postos (MELLO e COIMBRA, 2011:421) até uniformes da marca criada por do postos (MELLO

Em 2011, o escritório brasileiro de design e consultoria de marcas LED Project foi contratado para reformular a identidade visual da estatal, cuja estratégia corporativa estaria embasada no crescimento integrado rentabilidade e responsabilidade socioambiental. A articulação desses três pilares construiu a Missão e Visão 2030 da Petrobras (PETROBRAS, s.d.) Os elementos básicos que fundamentariam a nova identidade seriam a marca, as cores, a tipografia, as imagens e o elemento gráfico de apoio (FIGURA 201). A esses quatro elementos da linguagem visual, juntam-se

30

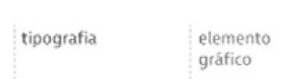

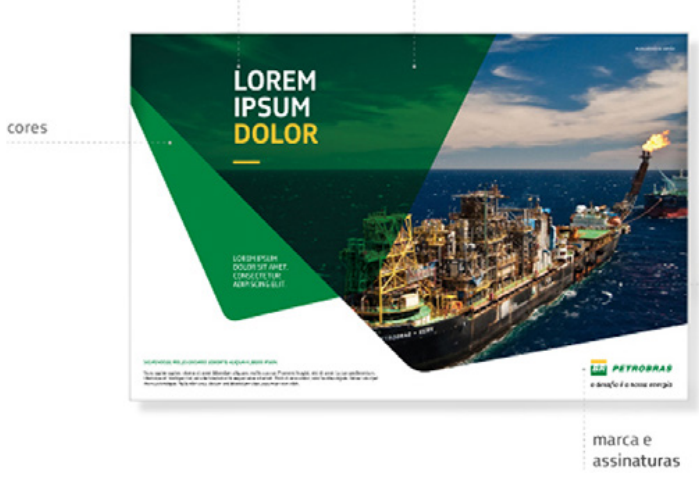

FIGURA 201_Prancha de apresentaç̃o para a identidade visual da Petrobras. LED Project, 2011 .

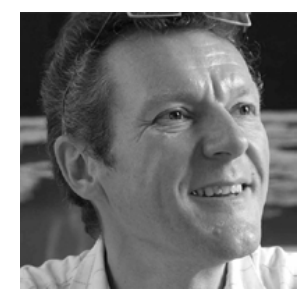

Bruno Maag

A Dalton Maag (DaMa) foi fundada en 1991 e baseada em Londres, Inglaterra, 0 designer suíço Bruno Maag dirige escritório que cria e desenvolve tipografias digitais, engenharia para fontes e serviços de apoio diretamente para empresas corporativas de pequeno a grande porte para agências de design de marcas. Com estúdios na Inglaterra, Áustria, Alemanh Hong Kong, Tailândia e Brasill. É responsável pela criaçăo das fontes para $\mathrm{O}$ Boticário (2011), uma adaptação da fonte Foco do brasileiro Fabio Haag, e da tipografia oficial para as Olimpiadas do Rio de Janeiro 2016 (2013). Entre as clientes da Dalton Maag estão marcas como Nokia, Toyota, BMW,

(D) 2008 , Fabio Haag Em 2008, Fabio Haag
foi incorporado à DaMa. É É designer de tipos e diretor da Dalton Sul Em 204 assumo ho America do de Desenvolvimento de Néćcios da de Desenvilume regrios da Bruno Maas nessa funçăo que então tornou chairman da empresa J́á projeto fontes corporativas par Toyota Noki McDonald's, O Boticário e Petrobras. Fontes: Foco, Effra e Cordale.

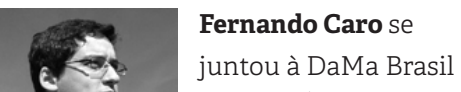

em zoll. É formado pela Faculdade de Arquitetura São Paulo. Trabalhou na typefounfry Touma mesmo tempo em que projetou fontes de modo independente. Fontes: Arauto, Soleto e Prometo. 
a linguagem verbal e formas de discurso, e a linguagem sonora, como entonação, voz e músicas. A tipografia deveria ser única, de uso exclusivo da Petrobras, e deveria refletir o momento de expansão da empresa, os novos conceitos atribuídos à marca, representar o seu caráter nacional e as suas qualidades técnicas e profissionais. Uma tipografia proprietária ${ }^{83}$ também traria a economia com compras de licenças para a grande base de usuários.

4.6.1 0 briefing e a conceituação da nova tipografia_A tarefa para a criação de uma tipografia exclusiva para a Petrobras foi encomendada à type foundry inglesa Dalton Maag (DaMa) que tem designers no Brasil entre eles, Fábio Haag e Fernado Caro. Em junho de 2011, os designers brasileiros iniciaram a maratona de projetos, versões de fontes e procedimentos técnicos que resultariam na família tipográfica Petrobras Sans.

Os conceitos-chave apontados no briefing ${ }^{84}$ desenvolvido pela LED Project e pela diretoria da Petrobras foram divididos em três grupos relacionados à postura empresarial interna e externa:

\section{Profissionalismo, competência, inovação, honestidade,}

objetividade e internacionalidade;

b. Brasilidade, simpatia, cordialidade e respeito à diversidade;

Tecnologia, modernidade e expertise.

Segundo os depoimentos de Haag e Caro (ANEXO II), além de considerar os conceitos citados, de ordem mais abrangente, a tipografia ainda precisaria atender a cinco requisitos básicos:

a. Acessibilidade: pois o público que consome, trabalha ou particip das atividades da instituição é muito grande, portanto a tipografia estaria em contato com a maior audiência possível, desde um proprietário de automóvel e o frentista do posto de combustível, ao diretor executivo da estatal ou um investidor internacional.

${ }_{33}$ Tipografia customizada projetada para uso exclusivo da instituição, que adquire (compra) os direitos de nciamento e distribuiçăo por tempo determinado ou indetermina do.

Informaçōes coletadas da apresentação da fonte Petrobras Sans pela equipe da Dalton Maag| Brasil, de b. Funcionalidade: que na visão dos designers significa que o design da tipografia precisaria se acomodar e representar bem qualquer função prática ou temática, tanto em materiais institucionais corporativos como em um cartaz sobre festas folclóricas nordestinas, uma etiqueta na

o5 bomba de gasolina, vinhetas gráficas de um filme publicitário para TV ou placas luminosas de estádios de futebol; recursos OpenType seriam necessários para atender as demandas de impressão e de ambientes digitais.

c. Atemporalidade: a fonte deveria ser livre de qualquer modismo com estrutura formal sólida e estável, portanto, a fonte precisaria se usada por ao menos 15 anos sem perder sua vitalidade;

d. Expressão: um contraponto difícil e aparentemente antagônico com o requisito anterior, pois qualquer detalhe mais exaltado "dataria" 15 muito a tipografia. O ponto de atenção do design deveria criar uma personalização e reforçar a identidade em processo de reconstrução. No depoimento de Haag (ANEXO II), o designer diz que a fonte precisaria se única ou, em suas palavras, "a fonte tinha que dizer: isso é a Petrobras".

Economia: a fonte precisaria ser ligeiramente condensada, o que resulta em uma economia de espaço nas composições. Para a escala de material impresso da Petrobras, uma economia de 3\% superior à fonte Helvetica (FIGURA 202), represen-

taria um ganho considerável no volume de papel utilizado e armazenado:

ABCDEFGHIJKLMNOPQ

Petrobras Sans Regular 20 pts

ABCDEFGHIJKLMNOPQ Helvetica Regular 20 pts

\subsubsection{A idealização: exploração de opçōes}

criativas A equipe brasileira da Dalton Maag trabalhou conjuntamente

3o com parte da equipe do escritório de Londres para formatar as ideias iniciais. Seguindo o fluxo de trabalho descrito no item 3.7.2.1 do capítulo 3 a primeira etapa, Idealização, se ocupou em produzir a maior quantidade possível de caminhos criativos que atenderiam ao briefing. Nessa fase, iniciada em junho de 2011, foram realizadas 42 opções que, na sua maioria,

não vieram de uma tipografia já existente que pudesse ser usada como ponto de partida. Apenas nove letras minúsculas foram desenhas, ' $n$ $\mathbf{o}, \mathbf{a}, \mathbf{i}, \mathbf{s}, \mathbf{h}, \mathbf{e}, \mathbf{f}, \mathbf{d}$ ', abrangendo as principais estruturas para todas as 


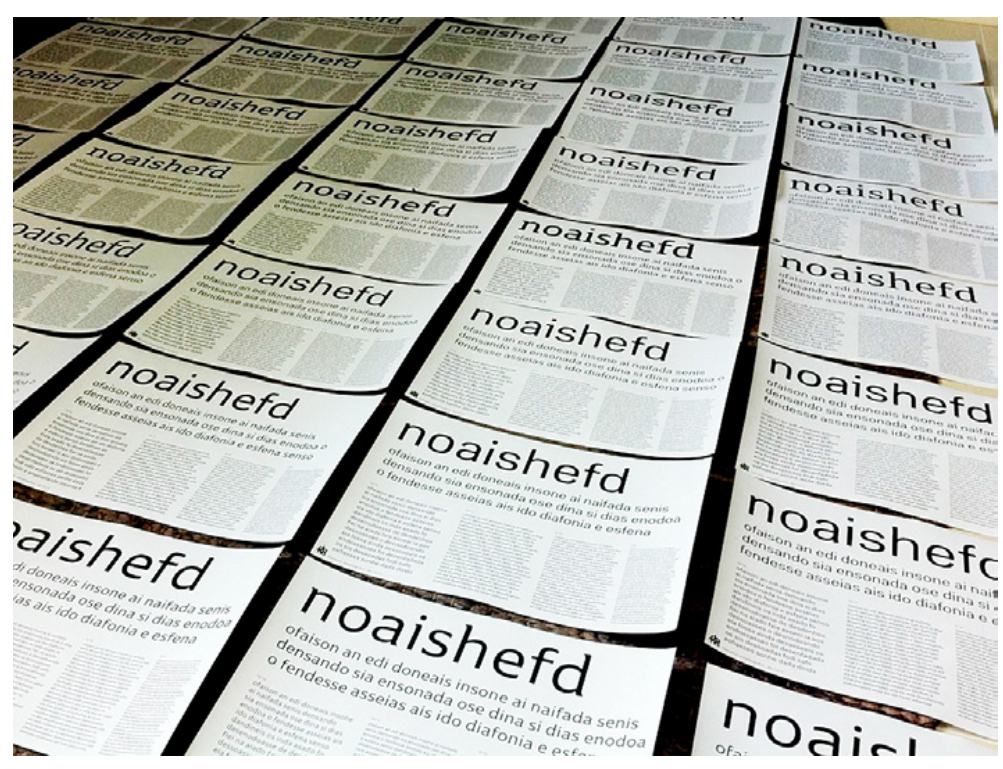

tras e, a partir dessa nove letras, textos foram gerados eletronicament para simular e testar desempenho do design espaçamentosem contex tos maiores (FIGURA 203).

Indagados sobre como os conceitos abstratos complexos do briefing (brasilidade, humaninade tc...) seriam traduzidos nas formas das letras, os designers afirmaram ser FIGURA 203_Provas impressas das uma questão muito subjetiva, baseada na intuição etapa de criação da fonte.

nama questão muito subjetiva, baseada na intuição curvas mais retangulares, proporciona uma sensação mais "tecnológica" e que remates encurvados dão suavidade e "humanidade" às letras. Contudo, curvas retangulares com mais contraste e modulação no traço podem pender para algo mais humano. De qualquer modo, as decisões são tomadas de acordo com o consenso das percepções de todos os designers envolvidos. Observando as amostras, pode-se concluir que os estudos elaboraram questões bastante diferentes em termos de estilo e de abordagens históricas, como as alternativas ao neogrotesco da Helvetica e Univers, opções mais próximas das sem serifas humanísticas como a Frutiger, designs com aberturas mais amplas, outros com aberturas mais fechadas, e algumas opçõe serifadas, desde as serifas quadradas às serifas ins nuadas, triangulares e transicionais (FIGURA 204). quantidade de opções se justifica, pois os designers da LED Project estavam trabalhando paralelamente em quatro caminhos criativos diferentes para noaishefd noaishefd noaishefd noaishefd noaishefd noaishefd noaishefd noaishefd noaishefd noaishefd noaishefd noaishefd noaishefd noaishefd noaishefd noaishefd noaishefd noaishefd noaishefd noaishefd noaishefd noaishefd noaishefd noaishefd noaishefd noaishefd noaishefd noaishefd noaishefd noaishefd noaishefd noaishefd noaishefd noaishefd
A totalidade desse trabalho (FIGURA 205) foi apresentada primeiramente aos designers da LED para uma primeira rodada de avaliações. da qual oito opções foram selecionadas:

- O desafio é a nossa energia - 0 desafio é a nossa energia O desafio é a nossa energia 0 desafio é a nossa energia 0 desafio é a nossa energia 0 desafio é a nossa energia O desafio é a nossa energia O desafio é a nossa energia

IIGURA 205_As oito op̧̧ões selecionadas pela LED e Dalton Maag

As descrições a seguir de A-H, referem-se à imagem acima.

A. É um design sem serifa, com construção das hastes com abordagem mais contemporânea e humanista verificada nas aberturas e no afinamento dos arcos do 'a, s, e, g'. Há um contraste muito sutil e detalhes mais orgânicos, como nos remates de 'a, d' e com curvas mais arredondadas, que segundo os tipógrafos (ANEXO II) "misturam aspectos humanos e tecnológicos":

B. Nessa opção sem serifa, o contraste é ligeiramente menos acentuado, as curvaturas do 'o' são um pouco mais retangulares, os remates são angulares em 'a, d, s, f, r, g', um detalhe considerado mais "moderno" pelos designers. Pingo do 'i' em forma de losango;

C. Uma variação da opção B, com um tratamento mais humanista nas curvas e junções e no ' $g$ ' de duplo andar; 
D. Outra variação da opção B, com tratamento mais "mecânico" da construção dos traços, como no arco superior do bojo do 'a' totalmente plano. Detalhe nas ascendentes com pequeno corte no lado direito;

E. Das opções selecionadas, esta é a mais diferenciada e com personalidade acentuada. A construção mais sólida e condensada tem alguns traços relacionados à caligrafia, como no bojo do 'a' e espinha do ' $\mathrm{g}$ '

F. Uma opção semisserifada, com formas claras e aberturas amplas dá a essa opção uma excelente legibilidade em tamanhos pequenos. O gancho do 'a' e o remate da descendente do ' $\mathrm{g}$ ' tem pequeno afinamento;

G. Esta é uma modificação da fonte Cordale (DaMa), com o propósito de ser uma acompanhante das opções B ou C para textos

pequenos mais longos. Os remates serifados dos ganchos de 'a, $\mathrm{f}$ coincidem com as inclinações dos mesmos remates das opções B e C. As serifas não são completamente distribuídas nas letras, como na haste direta do 'n' com serifa unilateral;

\section{H. Opção semelhante à G, com remates serifados mais curtos e} serifas mais presentes ('n' com serifas completas nesta opção).

Dessas oito opções selecionadas, quatro "rotas criativas" foram definidas, cada uma com algumas variações.

\section{onfidag onfidag onfidag} e suas quatro variaçōes.

Rota Criativa 1: tomando a opção anterior A, remates curvos foram plicados nas ascendentes ('d') contrapondo-se ao remate inclinado e reto do ' $n$ ', a letra 'i' recebeu pingo circular e remate curvo e o ' $\mathrm{g}$ ' foi desenhado sem sua forma de duplo andar tradicional, mas com design muito particular atribuindo mais expressividade e um apelo mais tecnológico. Na última variação, a serifa no topo do 'i’ foi removida e a espinha do 'g' ganhou uma curvatura mais fluida (FIGURA 206).
Rota Criativa 2: baseada na opção anterior F, é uma variação semisserifada, para uso preferencial em títulos, com serifas slab triangulares e com traços mais humanizados, como nos remates curvos do ' $n$, $d$. Letra 'g' em um andar e sem remate superior (orelha) (FIGURA 207).

Rota Criativa 3: é a opção mais limpa de excessos e considerada mais "tecnológica" pelos designers, mas com sutis detalhes humanizados. É um resultado de observações dos tipos FF Millo, FF Good, e de mais duas referências descartadas na primeira etapa. Tem uma proporção e construção dos traços parecidas com as da FF DIN com uma bo condensação para títulos, sem perder a legibilidade em corpos menores. Apesar da familiaridade com outros tipos, tem personalidade própria (FIGURA 208).

Rota Criativa 4: sua construção mais econômica na condução do traços que formam cada letra, atribui a esta opção um aspecto mais sintético e tecnológico, como observado na letra 'n, e, a', composto por um traço contínuo, longe da construção tradicional que tem interrupções. Há um pequeno contraste nas hastes, as curvas são ligeiramente retangulares. Detalhes na ascendente do ' $d$ ' com corte inclinado, base do 'a, d' sem remate, assim como o ' $\mathrm{g}$ ' sem orelha. Na segunda opção, as extremidades de algumas hastes foram arredondadas para atender aos requisitos do briefing que demandam atributos mais amigáveis (FIGURA 209).

4.6.3 A definição do conceito do design _ Das quatro rotas criativas sairiam as indicações para a construção da versão final. Testes impresso utilizando versões ainda incompletas das fontes foram realizados pela LED, aplicados nas peças gráficas que ainda estavam em fase de desenvolvimento sobrepondo títulos às imagens e cores do novo projeto.

A direção de criação da Dalton Maag, juntamente com os designers da LED concordou com a tese de que a opção mais adequada seria uma variação da rota $3^{85}$, agora com as terminações dos ganchos afinadas o que confere personalidade ao design já funcional, legível e de acordo com os conceitos e valores da Petrobras (FIGURA 210).

\section{onfidag onfidag}

FICURA 207_Rota criativa 2 e suds duas variações.

\section{onfidag}

opção única.

\section{onedag onedag}

IIGURA 209- 
PETROBRAS

0 desafio é a nossa energia

A ideia final foi expandida para 25 letras, pontuações e alguns algarismos para ampliar as possibilidades de testes com palavras textos. Versões de pesos do design final foram elaboradas para fins de teste de compatibilidade e contraste, verificando se as formas da versão regular permitiam uma boa expansão de pesos. Foram realizadas uma versão light, cinco variações do peso regular, uma bold e outras cinco variações do peso black. As versões itálicas foram trabalhadas com um pouco mais de liberdade, adquirindo certa flexibilidade com relação às romanas refletida nos movimentos mais caligráficos dos traços, o que proporciona melhor diferenciação estilística dentro da mesma família tipográfica (FIGURA 211). exemplo do que ocorreu com a tipografia Parisine, a preocupação com o rendimento da fonte foi um fator importante na decisão pelo design final. A fonte Petrobras Sans, comparada à Helvetica e Frutiger alcança um rendimento $2,4 \%$ e $4,8 \%$ melhor, respectivamente, sem perder 0 desempenho em legibilidade. $O$ processo de refinamento nos detalhes de cada curva (FIGURA 212) seguiu até a apresentação do projeto à Petrobras, para a qual a Dalton Maag preparou uma detalhada defesa técnica demonstrando o resultado qualitativo alcançado e comparações de rendimento e textura com as tipografias Helvetica, Frutiger e DIN. Essa é uma etapa importante, pois somente a partir das orientações e sugestões expostas, o projeto seguiu para a fase de execução, em que a complementação total dos caracteres foi realizada, idiomas suportados foram incluídos, a arquitetura de estilos definida e todo o laborioso processo de adequação técnica da fonte para aplicativos foi concretizado (cf. QUADRO I, capítulo 3 ).

4.6.4 Principais aspectos anatômicos da Petrobras Sans

A família Petrobras Sans é formada por quatro versões, Petrobras Sans light, Petrobras Sans Regular, Petrobras San Bold e Petrobras Sans Extra Bold, cada uma em suas versões romana e itálica totalizando estilos diferentes (FIGURA 213).

Petrobras Sans Light

Petrobras Sans Light Italic

Petrobras Sans Regular Petrobras Sans Regular Italic Petrobras Sans Bold Petrobras Sans Bold Italic Petrobras Sans Xbold

\section{Petrobras Sans Xbold Italic}


Os atributos formais da Petrobras Sans (FIGURA 214) são:

Construção contínua dos traços:

Formas curvas contínuas são redondas e ligeiramente retangulares,

como no 'o', e as curvas abertas são arrematadas com curvatura muito plana, como no 'a, e, c, f, g, j, s, t';

Hastes verticais são paralelas retas predominantemente sem remates das extremidades. A posição da linha média visualmente simétrica; Terminais da hastes retas são retos e ortogonais. Os ganchos ou arcos planos, como no 'a, c, C, e, f, g, G, j, J, s, S, t' são levemente afinados (FIGURA 215). Pingo das letras 'i,j' são circulares;

Proporção, é ligeiramente condensada, com as maiúsculas seguindo proporções regulares; a altura-de-x é média-alta com ascendentes da mesma altura que as maiúsculas:

Modelagem observa-se ausência de eixo inclinado, um pequeno contraste com transição gradual;

\section{ABCDEFGHIJKLM abcdefghijklmno}

HeVRA 214_ Petrobras partes mais importantes dos caracteres chave.
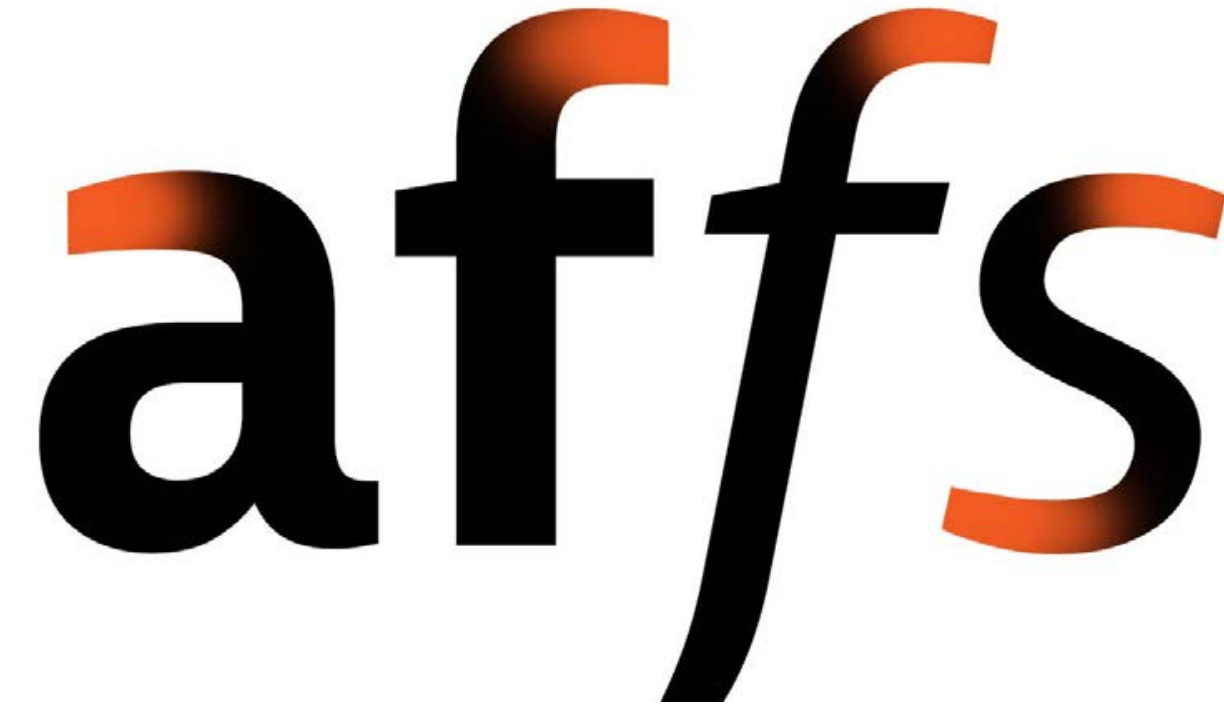
curvos que afinam, deixando parte interna das curvas mais planas.

\section{Caracteres-Chave:}

a, gancho com curvatura plana, conexão superior do bojo com a haste é abrupta e 'b d g p q' junção das curvas do bojo são

suaves, formando um miolo totalmente arredondado

$\mathbf{a}, \mathbf{c}, \mathbf{e}, \mathbf{f}, \mathbf{g}, \mathbf{j}, \mathbf{s}, \mathbf{t}$, curvas planas e levemente afinadas, assim

como nos algarismos '2, 3, 5 ':

n, m, u, com incisão diagonal:

i, com pingo redondo com proporções retangulares, assim como

no sinal de ponto final;

1, com remate curvo:

$\mathbf{t}$, lado esquerdo da barra chanfrado;

$\mathbf{K}, \mathbf{k}$, com junção do braço e perna conectada a uma barra horizontal e

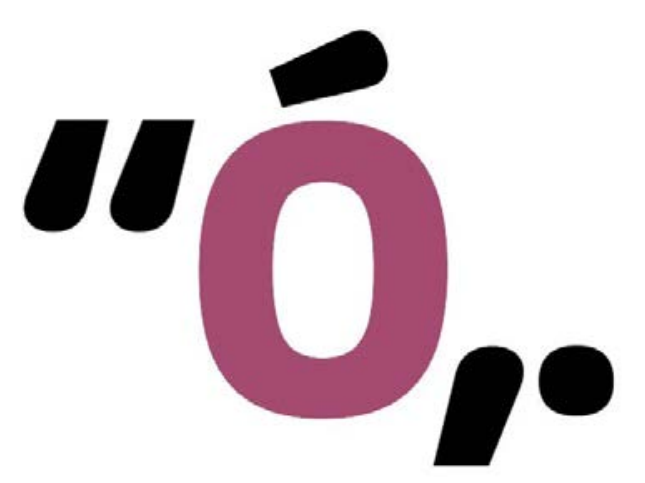

FIGURA 216_Forma sugestiva dos acentos, virgula, aspas e ponto, remete à forma è̀ densidade de uma gota de óleo. perna com remate curvo;

M, de proporção mais estreita e vértice muito elevado;

Q, cauda curta, curvada à direita, originada do centro da letra;

\section{NOPQRSTUVXYZ pqrstuvxyz \&1235}

$\mathbf{R}$, perna reta e diagonal, originada no meio do bojo, com remate final curvado;

s. com a curvatura de proporções retangulares, espinha plana e aberturas grandes;

\&. Espinha em diagonal reta, com remate final ascendente:

Vírgula, aspas, acentos agudo e crase com formato que remete à gota

de óleo (FIGURA 216). 
FIGURA 217_A tipografia usada como voz oficial para todas as

da Petrobras anunciando resultados do trimestre.
retrobas, anunciando
4.6.5 A expressão da Petrobras Sans na identidade visual_ $O$ projeto Petrobras Sans sempre esteve atento a duas questões centrais: a competição pelo bom rendimento no texto em relação às fontes Helvetica e Frutiger e alcançar um design que representasse a identidade da instituição. Comparações realizadas entre as três fontes ressaltam, na Helvetica, com suas maiúsculas rigidamente proporcionadas e aberturas muito fechadas, um aspecto frio e industrial enquanto a Petrobras San ganha ares mais humanizados com seus remates levemente afinados e aberturas mais generosas. Comparada à Frutiger, um tipo sem serifa humanístico, a Petrobras Sans é mais sólida e menos "humana", o que de certa forma, responde aos conceitos tão diversos do briefing que pede uma fonte com características de tecnologia, brasilidade internacionalidade, por exemplo. Como define Haag: “Essa é a beleza de uma fonte custom. Pode-se criar um caminho alternativo entre uma Frutiger e uma Helvetica. Um ajuste delicado entre os aspectos suave e humano, e do aspecto frio, técnico e pesado" (ANEXO II).

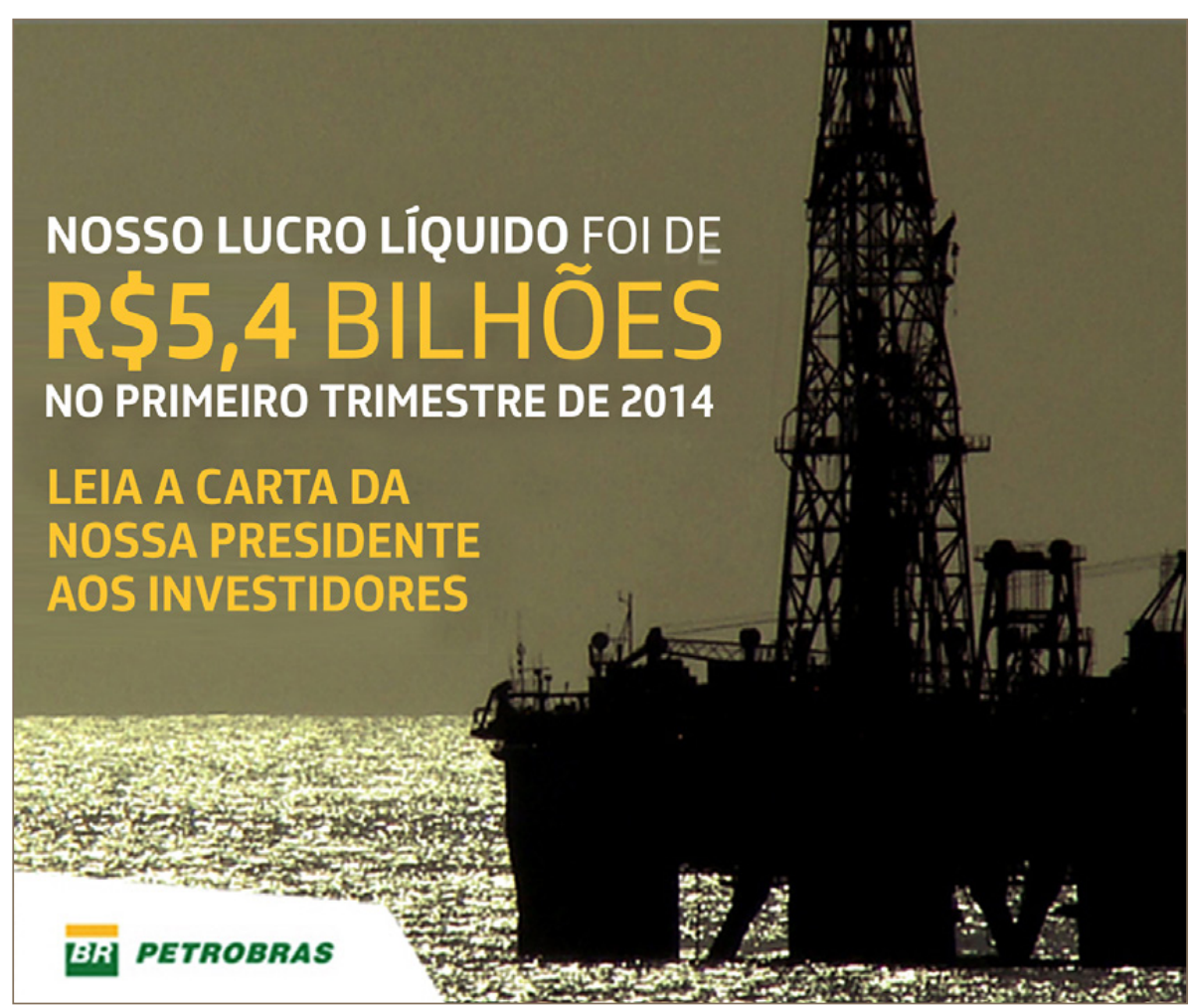

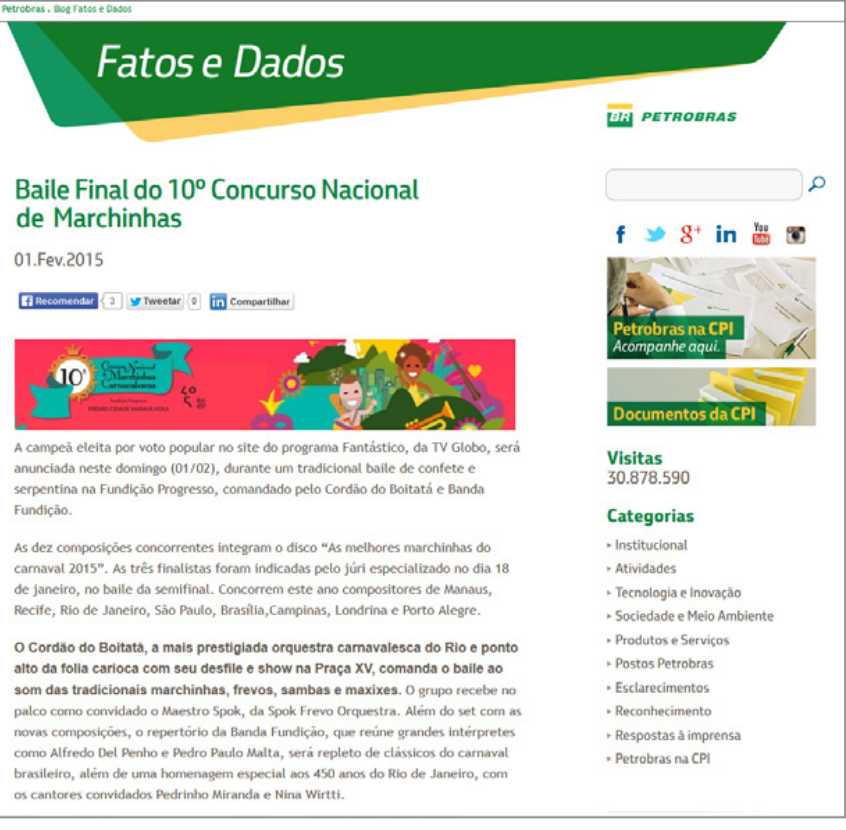

FIGURA 218_Página do website da

Petrobras com a tipografia associad

ao elemento gráfico de apoio (testeira).

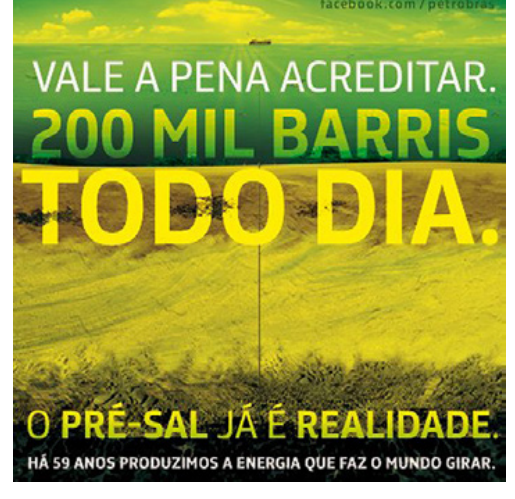

FIGURA 219_Peça gráfica de campanha publicitária utilizando a fonte sobre fundos colorido.
No material gráfico e digital produzido (FIGURA 217, 218 e 219), tipografia é usada como ponto focal das mensagens, predominando letras brancas ou em cor clara sobre fundos coloridos ou imagens. A proporção mais condensada permite um melhor aproveitamento dos espaços e a gama de variações de pesos e estilos é usada para criar hierarquia. A fonte

25 não é sobrecarregada de informações visuais e se aproxima muito de tipografias consideradas "neutras", que transmitem o seu conteúdo sem ser muito notada. Sua construção segue certo rigor, é estável e sólida. Uma proporção mais condensada na medida precisa permite acomodar uma quantidade de palavras e de texto de modo que o espaçamento

30 entreletras pode ser arejado, deixando uma impressão confortável para o leitor. Ao mesmo tempo em que se percebem a estabilidade e solidez das letras, as particularidades formais mais amigáveis também são transmitidas.

A conclusão total da família Petrobras Sans, com seus 4 pesos, mais os itálicos ( 8 versões no total) e seu conjunto de caracteres que suporta cerca de 100 idiomas, foi concluído em abril de 2012 
CONSIDERAÇÕES

FINAIS

Partindo do pressuposto inicial desta dissertação segundo o qual a tipografia é um componente fundamental na estrutura de um sistema de identidade visual, o estudo das seis fontes customiza-

das aplicadas demonstrou o potencial para assumir o papel da própria marca como um signo visual representativo da identidade. Usando-se a fonte Walker como exemplo, podemos dizer que por meio dela, Matthew Carter construiu as bases expressivas da nova comunicação visual do Walker Art Center, desde seu logotipo até todas as peças gráficas produzidas, carregadas de textos que explicitavam o caráte multifacetado dos eventos e do público frequentador do museu. Tipos com essa carga de personalidade e expressão podem suportar a identidade da instituição nas situações em que apenas os textos estão atuando, com a marca e cores institucionais ausentes, assumindo o papel de identificar

Algo similar pode ser dito a respeito das famílias tipográficas Parisine, para a sinalização do sistema de transportes parisiense e da Guardian Egyptian, para o The Guardian, pois, afinal, cerca de $80 \%$ do material editorial consiste de tipos (MOEN, 2000:96) e o contato constante do leitor com as sutilezas do design tipográfico criam uma experiência muito próxima entre o leitor e a identidade do jornal.

A família Yale, criada para a universidade norte-americana, foi responsável pela recuperação de uma tradição tipográfica da instituição baseada em tipos aldinos. Foi aplicada nas várias camadas da sinalização do campus e distribuída para todos os alunos, professores e funcionários, criando um ponto de contato entre todos eles, codificado pelo uso da tipografia.

A família Petrobras Sans foi criada com o intuito unificar a linguagem tipográfica da instituição, antes pulverizada em tipos diferentes e mal empregados. Mesmo composta por um conjunto pequeno de fontes (oito) se comparada à família Guardian tem as variações de pesos e itálicos suficientes para suprir a demanda da comunicação da Petrobras que apesar de não ser excessivamente exposta ao público, carecia de uma voz unificada, personalizada e, também, conectada com o seu tempo

O objetivo central da pesquisa que deu origem a esta dissertação foi compreender e analisar o processo de elaboração e tradução de conceitos subjetivos e emocionais, processados pelo designer de tipos, e aplicados na configuração formal de tipografias exclusivas adotadas por sistemas de identidades visuais. Isso implicou em investigar quais mecanismos, estruturas ou formas tornam um design tipográfico mais ou menos adequados a certos tipos de mensagens. Questionamentos sobre quais seriam, por exemplo, a melhor proporção, contraste, detalhes dos remates, que fazem uma fonte se adequar ao discurso específico de uma empresa

automobilística, ou a uma instituição cultural da área literária ou uma escola pública do ensino fundamental, são frequentementes suscitados pelos designers de tipos no momento de definir as estruturas que as letras devem ter para expressar corretamente seus propósitos.

Para isso, três assuntos correlatos foram estudados para alinhar

conceitos e definir vocabulário e procedimentos: a tipografia como elemento construtor de identidades e como ela compõe os sistemas de identidade visual; as características expressivas e emocionais impreg nadas do design dos tipos e como os indivíduos reagem a isso; e o que é e como se desenvolve uma fonte digital personalizada para instituições

15 corporativas. O estudo das seis fontes customizadas exigiu, além das poucas referências bibliográficas, o contato direto com os designers e visitas aos locais onde as tipografias estão instaladas, como nos casos do metrô de Paris e o Rijksmuseum. Esses meios possibilitaram reunir um registro importante sobre as fontes e, em alguns casos, inédito.

Aprofundando em questões mais minuciosas do design das letras. as análises do capítulo 4 exploram os aspectos quase imperceptíveis nas formas das letras que conferem a elas atributos distintos e personalidades próprias, como o que torna uma contraforma mais simples e arredondada, mais amigável e confortável, do que uma outra, formada por curvas e quinas,

ou ainda, por exemplo, porque a fonte Univers é preferida por alguns, pelas suas curvas mais elegantes mais bem "tensionadas" do que a Helvetica Neue, fontes com design e propostas quase idênticas (FIGURA 220).

\section{agsd agsd}

FIGURA 219_Caracteres $d a$ 
Os depoimentos coletados ou escritos pelos designers das seis fontes o1 indicam que, tais descrições dos aspectos subjetivos, são fundamentadas em avaliações pessoais, formadas por sensações e baseadas em seus repertórios visuais e históricos da tipografia. No caso de um projeto corporativo, as decisões de design também são guiadas pela intuição e discernimento do designer e dos responsáveis por parte da instituição. Quando os designers tratam e descrevem suas decisões, comumente as fazem de forma subjetiva e pessoal, pois não há um princípio aparente que estruture ou garanta que um design tipográfico seja mais eficiente ou mais apropriado, a certas mensagens ou públicos, do que outro. Portanto, compreender objetivamente como se processa a tradução de adjetivos em formas tipográficas, necessita observar a percepção de um conjunto muito maior e mais diverso de indivíduos e em períodos com certa frequência, pois esses fatores estão diretamente relacionados à percepção que esses têm das formas tipográficas.

Essas perguntas, a princípio, parecem não ter respostas conclusivas, ficando, muitas vezes, circunscritas aos resultados de pesquisas e testes já realizados, algumas delas citadas no CAPÍTULO 2. Apesar das tentativas de racionalizar a expressividade dos tipos e a reação emocional que estes causam nos leitores sob a forma de pesquisas quantitativas e qualitativas, os resultados que esses estudos apresentam se limitam a listas classificatórias ou tabelas com pontuações, que demonstram a afinidade dos tipos com atributos emocionais predeterminados pelo autor de cada pesquisa (CAPÍtulo 2.3). As conclusões desses estudos determinam fatos, constatam que um determinado grupo de indivíduos reage de maneira semelhante aos estímulos proporcionados por tipografias, mas não apontam motivos mais racionais para que um ou outro tipo de letra produza as respostas emocionais do indivíduo testado. Ao menos, essas pesquisas não se propuseram a chegar a esse tipo de resultado mais apurado. $O$ que se constata, ao analisar essas pesquisas, é que quando somos expostos a uma tipografia, é difícil obter uma resposta mais concreta que identifique a origem exata das emoções ou atributos subjetivos percebidos. Se, por um lado, a grande quantidade de fontes disponiveis torna a tarefa de diferenciar e identificar mais difícil, por outro, a continuidade desta pesquisa poderia investigar se a acuidade visual das novas gerações, expostas a um enorme volume de informações visuais, cria uma capacidade maior de perceber detalhes o1 que possam representar uma imagem única e criar personalização. Como foi exposto no CAPítulo 2, a tipografia é apreendida de duas maneiras: primeiramente, seus signos são lidos, e sua mensagem denotativa é compreendida; na sequência, ou simultaneamente, a imagem de suas letras,

o5 palavras e o conjunto de textos são percebidos, agem como um gatilho que desencadeiam emoções, sentimentos ou lembranças. Contudo, essa não é uma ciência exata.

Os resultados da pesquisa realizada para esta dissertação indicam que a personalidade de uma tipografia é construída por vários fatores,

10 entre eles: a relação do seu design com a linguagem estética de seu tempo (CAṔ́TULO 2.1); de sua conexão com a cultura local, seja ela nacional ou mais regionalizada, refletindo um ideal, um pensamento ou a tradição de um grupo; a presença de elementos idiomáticos particulares (CAPÍtULO 4.1) o que reforça a questão anterior; a frequência com que certos tipos são

15 expostos ao público, e com que espécie de tema ou produto estão geralmente associados, gerando um "gosto" predominante que é replicado continuamente (CAPÍTULO 2.4); a capacidade de memorização e diferenciação das formas tipográficas, o que implica em respostas cognitivas mais eficientes; e o emprego de referências visuais já estabelecidas 20 no imaginário das pessoas, estabelecendo uma reação imediata das percepções pretendidas (CAPÍTULO 2.2)

Uma primeira conclusão é que o design tipográfico impõe sua personalidade ao público, e não o inverso, ou seja, apesar de estarem conectados ao espírito de seu tempo e lugar, os tipos possuem certa

autonomia em criar familiaridade e estímulos emocionais, dependendo apenas da maneira e frequência com que são apresentados ao público. Foi o que o designer Paul van der Laan pretendeu para a fonte Rijksmuseum ao introduzir, entre outros elementos, um corte diagonal no topo das ascendendes das letras minúsculas (CAPítulo 4.1, FIGURA 086).

30 A inclusão desse detalhe intenciona diferenciar a fonte de outras semelhantes e relacioná-la diretamente ao museu, apoiando a ideia de que a identidade, na tipografia, é algo para ser construído a partir da exposição do público com o design. Mesmo as tipografias não exclusivas disponíveis comercialmente, quando são apresentadas em uma estru-

tura gráfica sistematizada e regular, seja por uma cor, tamanho ou disposição no espaço, também criam uma reação por parte do espectador, e dependendo de cada situação, podem consolidar uma identidade. Mas 
quando a tipografia em questão é um tipo customizado, original e de uso exclusivo da instituição, essa relação e capacidade identitária, segundo as observações dos designers e dos envolvidos nos projetos estudados (capítulo 4) é potencializada, facilitam o reconhecimento, criam empatia, causam impacto no cotidiano visual e na memória do usuário, agindo como um aroma persistente em certos locais ou situações que marca, identifica, memoriza, aqueles momentos.

Outro ponto importante que este trabalho permitiu explorar foi processo de desenvolvimento de uma fonte digital praticado por type foundries de diversos portes, com ênfase nas fontes customizadas de uso corporativo exclusivo. $\mathrm{O}$ resultado dessa pesquisa, ainda que limitada a poucos designers, permitiu compilar e organizar os procedimentos operacionais para a criação de fontes dessa natureza. 0 resultado pode ser observado no quadro que demonstra a Progressão do Desenvolvimento de uma fonte customizada (CAPítulo 3, p. 130), que inclui as etapas de concepção, criação, produção e implementação de um projeto. O quadro relaciona ainda os principais tipos de informações que o briefing deve fornecer ao designer, auxiliando o próprio contratante a tornar clara as suas intenções e necessidade. A participação efetiva do contratante no processo de criação e desenvolvimento também pontuada em cada etapa, sinalizando como essa relação pode ou deve acontecer para se alcançar o aproveitamento máximo das competências de cada profissional envolvido. Seu conteúdo se aplica como referência e ponto de partida para designers ou contratantes de tipografias customizadas organizarem seus procedimentos, otimizando tempo custos e trabalho. Entretanto, o conteúdo desse quadro ainda é um esquema introdutório para o assunto, requerendo ainda a ampliação e verificação das informações junto a um universo mais amplo de designers e type foundries

REFERÊNCIAS

Bibliografia Manuais de Identidade Visuais e Style Guides Online Website 


\section{Bibliografia}

AAKER, David. Marcas: Brand Equity. Gerenciando o valor da marca. São Paulo: Elsevier Editora, 1998.

AAKER, Jennifer L. Dimensions of Brand Personality. Journal of Marketing Research; 1997.

ADOBE. OpenType. Disponível em: <http://www.adobe.com/products/type/opentype. html>. Acesso em: 24 Nov. 2014.

AICHER, Otl. Tipografía, Valencia: Campgràific, 2004

BAIN, Peter; SHAW, Paul (edit.). Blackletter: Type and National Identity. New York: Princeton Arch.Press, 1998

BAINES, Phil; HASLAM, Andrew. Type and Typography. London: Lawrence King Publishing, 2002. ; DIXON, Catherine. Sense of Place. Three new typefaces for local institutions

BARTHES, Roland. Image, Music, Text. Nova York: Hill and Wang, 1977.

BAUMAN, Zygmunt. Identidade. Entrevista a Benedetto Vecchi. Rio de Jan.: Zahar, 2005.

BEIER, Sofie. Reading Letters - designing for legibility. Amsterdam: Bis Publ., 2012.

BILAK, Peter. Dutch type design. Ensaio. Typotheque, 2004. Disponível em: <https:// www.typotheque.com/articles/dutch_type_design>. Acesso em: 03 Nov. 2013.

. We don't need new fonts Artigo, Tipotheque e 8 Faces Magazine \#3, 2011. Disponivel em: <https://www.typotheque.com/articles/we_dont_need_new_ fonts>. Acesso em: 18 Set. 2014.

BLACK, Roger. Modern and austere: The next generation of newspaper typography? Blog Roger Black. o3 Out. 2006. Disponível em: <http://archive.rogerblack.
com/blog/next_news_typography>. Acesso em: 18 Jan. 2015.

BLACKWELL, Lewis. Tipografia del Siglo XX. Barcelona: Editorial Gustavo Gili, 2007 BLAUVEIT, Andrew Mathew Carter. Walker Magazine, 2005 Disponivel en: chtp:// wwwwakerartorg/magazine/2005/matthew-carter> Acesso em: 12 Dez 204 BELL, Nick. The Walker Art Center has a new identity - multi-voiced reflexive - that does exactly what it says. Eye Magazine no. 59, 2006. Disponível em: <http://www.eyemagazine.com/feature/article/unfurling-

BOKLAND, Erik van. Value of Type. Artigo para FontZone.com, 1997. Disponível en <http://letterror.com/writing/the-value-of-type/>. Acesso em o1 Nov. 2014.

BOLD MONDAY. Panno Typeface. Disponível em: <http://www.boldmonday.com/en/ pannosign>. Acesso em: 21 Nov. 2013

BONSIEPE, Gui. Design, Cultura e Sociedade. São Paulo: Blucher, 2011.
BOULTON, Mark. Five Simple Steps to Better Typography. Londres:@media, 2007 BOZTEPE, Uygar. AEG \& Peter Behrens: Symbolism in the first Corporate Identity Design. Mestrado. Izmir, 2012

BRAGA, Marcos da C. (org.) O Papel Social do Design Gráfico: História, conceitos \& atuação profissional. São Paulo: Ed. Senac, 2011.

BRANIGAN, Tania. An Egyptian dynasty, founded on letters, is meticulously but quietly restored. London: The Guardian News and Media Archive, 10 Set. 2005. Disponivel em. < A Ap. $/ /$ www. heguardian.com

BRINGHURST, Robert. Elementos do Estilo Tipográfico. version 3.o. São Paulo: Cosac Naify, 2005.

BRODY, Neville; WOZENCROFT, Jon. FUSE 1-20. From Invention to Antimatter Twenty years of FUSE. Colônia: Taschen, 2012.

BRUMBERGER, Eva R. The Rhetoric of Typography: The persona of typeface and text. (Applied Research). Technical Communication, 2003 a. v.50, n 2, p.206.

The Rethoric of Typography: The Awareness and Impacto $f$ Typeface Appropriateness. (Applied Research). Technical Communication, 2003 b. v.30 no 2 p.224.

BUDELMANN, K., KIM, Y. e WOZNIAK, C. Brand Identity Essentials. Massachusets Rockport 2010

CALAHAN, Anthony. Multitudes of Interpretations: Intentions, connotations and associations of typefaces designs. In Research Journal of the Australian
Graphic Design Association vol III n ${ }^{\circ} 1$, 2007 pags. $9-18$.

CAPRIOTTI, Paul. Branding Corporativo. Fundamentos para la gestión estratégica de la Identidad Corporativa. za ed. Santiago, Chile: Librería de la Empresa, 2009.

CARDOSO, Rafael (org.). O design brasileiro antes do design: aspectos da história gráfica, 1870-1960. São Paulo: Cosac Naify, 2005.

Uma introdução à história do design. зa Ed. Rev. Ampl. São Paulo: Blucher, 2008.

CARTER, Sebastian. Twentieth Century Type Designers. Hampshire: Lund Humphries, 2002

CAUDURO, João Carlos. Planejamento visual urbano: O sistema do metrô de São Paulo. Vol. 1, 2 e 3. 1972. Tese de Doutorado - Faculdade de Arquitetura e Urbanismo da Universidade de São Paulo, São Paulo, 1972.

CHAVES, Norberto. La Imagen Corporativa. Teoría y práctica de la identificación institucional. $3^{a}$ Ed. Barcelona: Gustavo Gili Diseño, 2005

_ Pensamento Tipológico. Artigo. Portal Foroalfa. Publicado em 25 de junho de 2012 Disponivel em: <http://foroalfa.org/articulos/pensamento-tipologico>. Acesso em: 26 Jun. 2014

CHAPARRO, Barbara S.; FOX, Doug; SHAIKH, A. Dawn. Perceptions of Fonts: Perceived personality traits and uses. Usability News. Fevereiro de 2006, vol.8, 1 ediçãa. 
CHILDERS, T. L. e JASS, J. All Dressed up with Something to Say: Effects of typeface (a)

ONSOLO, Cecilia. Marcas. A expansão simbólica da identidade. 2012. Tese (Doutorado em Ciências da Comunicação) - Universidade de São Paulo.

COSTA, Joan. A Imagem da Marca. Um fenômeno social. São Paulo: Ed. Rosari, (2005) 2011.

CULLEN, Moira. The Space Between the Letters. In: HELLER, Steven; MEGGS, Philip B. (Edit.). Textos on Type- Critical Writings On Typography. New York: Allworth Press, 2001. P. 93-97

DALTON MAAG. About Us. Disponível em: <https://www.daltonmaag.com/about-us> . Acesso em: og Fev. 2015.

DE VINNE, Theodore L. Plain Printing Types. A Treatise on the process of type-making the point system, the names, sizes and the styles of type. New York: Oswald

DIETZSCH, Rafael. Fontes Livres e Tipografia Institucional. Revista Tupigrafia São Paulo: Oficina tipográfica de São Paulo, pg. 47-49, Maio de 2010.

DIXON, Catherine. DescribingTypeforms: a designer's response. InfoDesign, v.5_n ${ }^{\circ}{ }_{2} 2008$.

. Typeform Dialogues; Description Framework Texts (reformatado) Apendice G, 2012.

DODD, Robin. From Gutenberg to Open Type. Vancouver: Hartley \& Marks Publ. 2006.

DOYLE, J.R.; BOTTOMLEY,P.A. Font Appropriateness and Brand Choice. Journal of Business Research n 57, pg 873, 2004 .

DUTCH TYPE LIBRAY. DTL Documenta . 2014. Disponível em: <http://www.dutchtypelibrary.nl/>>. Acesso em: 12 Dez. 2014.

EARLS, David. Designing Typefaces. Mies: Rotovision, 2002.

ESTEVES, Ricardo. 0 Design Brasileiro de Tipos Digitais. São Paulo: Ed. Rosari, 2010.

EYE MAGAZINE. Reputations: Matthew Carter. Edição 11, 1993. Disponivel em: $\mathrm{htp}: / /$ www.eyemagazine.com/feature/article/reputations-matthew-carter > Acesso em. 08 Fev. 2015

EARIAS, Priscila Lena. Tipografia Digital - O impacto das novas tecnologias. Rio de Janeiro: 2AB, 1998.

Semiótica e Cognição: os conceitos de hábito e mudança de hábito em

C.S.Pierce. Revista Eletrônica Informação e Cognição, vol. 1, ño 1 p.12-16, 1999.

Legibilidade e Tipografia. Tupigrafia 3, p. 26 - 28, 2002.

Notas para uma Normatização da Nomenclatura Tipográfica. Anais do P\&D

Design 2004a - $6^{\circ}$ Congresso Brasileiro de Pesquisa e Desenvolvimento em
FARIAS, Priscila Lena; SILVA, Fabio L.C.M. Classificações Tipográficas: sistemas de classificação cruzada. Anais do P\&D Design 2004b. FAAP: São Paulo.

FARIAS, Priscila Lena. Aprendendo com as Ruas: a tipografia e o vernacular.In BRAGA, Marcos da C.. (org.) O Papel Social do Design Gráfico: história, conceitos \& atuação profissional. São Paulo: Ed. Senac, 2011.

FASCIONI, Lígia. Método para Definição da Identidade Corporativa. $8^{\circ}$ Congresso Brasileiro de Pesquisa em Design, São Paulo, 8-11 de outubro de 2008. Disponivel em: <http://www.ligiafascioni.com.br/wp-content//
uploads/2010/08/IdentidadeGIIC1.pdf >. Acesso em: 24/06/2014.

FONTANA, Rubén. De Signos y Siglos. ForoAlfa. Buenos Aires, o1 de julho de 2005. Disponivel em: <http://foroalfa.org/es/articulo/2/De signos_Y_siglos>. Acesso m: 18 Nov. 2014.

FONTS.COM. Domani. Disponivel em: <http://www.fonts.com/font/counterpoint-typestudio/domanis. Acesso em: 27 Dez. 2014.

FONTSMITH Xerox. Case studies. Disponivel em: <http://www fontsmith.com/caseStudies/xerox>. Acesso em: 28 Dez. 2014

15 FOX, Doug. Free Will for Typeface Selection: myth or reality? Usability News. 2010 ERASCARA, Jorge. El Diseño de Comunicación. Buenos Aires: Infinito, 2006.

FRANCHI, Francesco. Designing News. Changing the World of Editorial Design \& Information Graphics. Berlin: Gestalten, 2013.

FREEMAN, Judi. The Visual Word, In Art journal, Vol. 54 n²2, 1995.

FRUTIGER, Adrian. Reflexiones sobre Signos y Caracteres. Barcelona: Editoria Gustavo Gili, 2007.

.En Torno a la Tipografía. Barcelona: Editorial Gustavo Gili, 2004 [2001].

GILL, Eric. An Essay on Typography. London: Lund Humphries, 1988 (1931).

25 GRAVIER, Laura Garone. La Escritura y Su Función en El Desarrollo Social. In: CONSOLO, C. (Comp.). Tipografía em Latinoamérica. Orígenes e Identidad. São Paulo: Ed. Blucher, 2013.

GRAY, Nicolete. A History of Lettering. Creative experiment and letter identity. Boston: Godine, 1986.

GUARDIAN, The. Document in focus. Design brief, Michael McNay to David Hillman, 1987. Guardian News \& Media Archive. Disponível em: <http://www
theguardian.com/gnm-archive/2005/oct/15/2>. Acessos em: 12 Jan. 2015 .

The Berliner Format. Guardian Print Centre, 20o9. Disponível em: < http:// www.theguardian.com/gpc/berliner-format>. Acesso em: 11 Nov. 20013.

GUARDIAN, The. History of the Guardian. A brief history of the Guardian newspaper. Guardian News \& Media Archive, 2005. Disponivel em: <http://
www.theguardian.com/gnm-archive/2005/aug/19/1 1 . Acesso em: 11 Jan. 2015. 
HALLMUNDUR, Aegir. Genuine Imitations. I Love Typography, 2009. Disponível em: < http://ilovetypography.com/2009/06/03/genuine-revivals-matthew-carter-ontypeface-revivals/ > . Acesso em: 18 Nov. 20014 .

HAUSER, Arnold. História Social da Literatura e da Arte. Vol. I, $4^{\mathrm{a}}$ ed. São Paulo: Mestre Jou, 1982.

HEITLINGER, Paulo. Tipografia. Origens formas e uso das letras. Lisboa: Dinalivro, 2006.

HIGHSMITH, Cyrus. Do We Need More Fonts? Disponível em: <http://tdc.org/tdc/ archives/139>. Acesso em: 24 de set. 2014

HELLER, Steven; Lou Dorfsman, Design Chief at CBS, Dies at 90. The New York Times. 2008. Disponivel em: <http://www.nytimes.com/2008/10/26/ nyregion/26dorfsman.html?_r=0>. Acesso em: 30 Dez. 2014.

MEGGS, Philip B. Texts on Type - Critical Writings On Typography. New York: Allworth Press, 2001 .

HENDERSON, Drew. Yale Press Drops Distinctive Logo. Yale Daily News, 2009. Disponível em: $<$ http://yaledailynews.com/blog/2009/09/30/yale-press-drops-distinctivelogo/>. Acesso em: 15 Jan. 2015

HENDERSON, Pamela W:; GIESE, Joan L:; COTE, Joseph A. Impression Management Using Typeface Design. The Journal of Marketing. Abril de 2004

HENESTROSA, Cristóbal; MESEGUER, Laura; SCAGLIONE, José. Como Criar Tipos: do Esbôço à Tela. Estereográfica Editorial: Brasília, 2014.

HLASTA, Stanley C. Printing Types \& How to Use Them. Pittsburgh: CarnegiePress, 1950.20

HOCHULI, Jost. Detail in Typography. London: Hyphen Press, 2008.

HOEFLER, Jonathan. Hoefler\&Co. Custom Fonts. Disponível em: <http://www.typography. com/custom>. Acesso em: 10 Dez.2014.

HOFFMAN, Phyllis R. Matthew Carter: Reflects on Type Design. 1999. 201 fls. Dissertação (Mestrado em Ciências) - School of Printing Management and Science ofTechnology, Nova York, 1999.

HOFMAN, Veronica M. Upon Reader's Perception of the Meanings of Messages Usin the Semantic Differential Testing Technique. (mestrado) School of Printing Management and Sciences of the Rochester Institute of Technology. New

HOLLIS, Richard. Design Gráfico: uma história concisa. São Paulo: Martins Fontes, 2001. HYLAND, Angus; KING, Emily. Identités Graphiques \& Culturelles. Paris: Pyramyd, 2006. IDENTIFONTS. Christian Schwartz. Disponível em: <http://www.identifont.com/ show?4JW>. Acesso em: 14 Fev. 2015

JACKSON, Brandon. The Yale Typeface. The New Journal, 2012. Disponível em: <https:// pt.scribd.com/doc/106574480/The-Yale-Typeface >. Acesso em: 10 Dez. 2013
JURY, David. About Face. Reviving the rules of typography. Mies: Roto Vision, 2004 KAPFERER, Jean-Noël. As Marcas, Capital da Empresa: criar e desenvolver marcas fortes. $3^{\mathrm{a}}$ Ed. Porto Alegre: Bookman, 2003

KASTL, Albert J.; CHILD, Irvin L. Emotional Meaning of Four Typographical Variables Yale University: Jornal of Applied Psychology, 1968, Vol. 52, No 6, 440-446.

KEEDY, J. The rules of typographt according to crackpots experts. In Eye no11, 1993.

KENNEDY, Gabrielle. Irma Boom and "The Rijks". Design.nl - Dutch Design News Website. 2012. Disponível em: <http://design.nl/item/irma_boom_and_the_rijks> Website. 2012. Disponivel en:
Acesso em: o2 de Jan. 2015.

10 KING, Emily. New Faces. Chapter Three: East Coast. 1999. Tese (Doutorado). Kingston University, 1999. Disponivel em. <ittps://www.typotheque.com/articles/new_ faces_chapter_three_the_est_Cost> Acesso em: 06 Jan.2015

LAWSON, Alexander. Anatomy of a Typeface. Boston: David R. Godine. 1990.

LEONIDAS, Gerry. et al. Typographic Referenced. A comprehensive visual guide to the language, history, and practice of typography. Massachussets:

LEROY-GOURHAN, André. O Gesto e a Palabra. 2 - Memória e Ritmos. Lisboa: Edições 70, 2002.

LEWIS, Clive; WALKER, Peter. Typographic Influences on Reading. British Journal of Psycology. 1989, vol. 80, p241-257.

20 LONGO Jr. Celso Carlos. Design Total: Cauduro Martino, 1967-1977. (Mestrado, FAU/ USP) São Paulo, 2007.

LOXLEY, Simon. Type: The Secret History of Letters. Londres: I. B. Tauris \& Co. 2004

LUPTON, Ellen. A Post-Mortem on Deconstruction? In AIGA Journal of Graphic Design 12, \#2, 1994.

25 LUCAS FONTS. Interpolation Theory. Disponível em: <http://www.lucasfonts.com/ about/interpolation-theory/>. Acesso em 24 Dez. 2014

MAAG, Dalton. Font Book Collection 01. Londres: Dalton Maag, 2003.

McCOY, Katherine. Countering the Tradition of the Apolitical Designer. In Design Renaissance: Selected Papers from the International Deign Congress,

Glasgow, Scotland, 1993.

MANDEL, Ladislas. Escritas-Espelho dos Homens e das Sociedades. São Paulo: Ediçōes Rosari, (1998) 2006.

MARTINS, Daniel R. La letra como Signo de identidade Visual Corporativa. Codificación y decodificación visual del sistema de identidade. Doutorado.
Universidade Técnica de Lisboa, Faculdade de Arquitectura. Lisboa: 2012.

35 MEGGS, Philip B. PURVIS, Alston W. História do Design Gráfico. Cosac Naify: São Paulo, 2009 
MELLO E Homem de: COIMBRA Elaine R (Orgs) Linha do Tempo do Design no Brasil. São Paulo: Cosac Naify, 2011.

MERMOZ, Gérard. On Typographic Reference, part I. University of Nebraska Press, 1991. MESSEGUER, Laura. TypoMag - Typography in magazines. Amsterdam: Bis Publishers, 2011.

MICROSOFT. What is OpenType? Disponível em: <http://www.microsoft.com/en-us/ Typography/WhatIsOpenType.aspx>. Acesso em: 27 Dez. 2014.

MIDDENDORP, Jan. Dutch Type. Rotterdam: IOI Publishers, 2004. : Shaping Text. Amsterdam: BIS Publishers, 2012.

SPIEKERMANN, Erik. Made with FontFont. Types for independent minds. Amsterdam: BIS Publishers, 2006

MILLER, J. Abbott; LUPTON, Ellen, A Natural History of Typography. In: BIERUT, M. DRENTTEL, W.; HELLER, S.; HOLLAND, DK, (Edit.) Looking Closer. Citical Writings on Graphic Design. Nova York: Allworth Press, 1994.

MIRSKY, Laurende. The Cryestalline Plant. In: BAIN, Peter; SHAW, Paul (edit) Blackletter: Type and National Identity. New York: Princeton Arch Press, 1998.

MÜLLER-BROCKMANN, Josef. Historia de la Comunicación Visual. México DF G.Gili, $2^{\mathrm{a}}$ ed., 2001.

MINGUEZ, Norberto. Un marco conceptual para la comunicación corporativa. Bilbao: Revista de Estudios de Comunicación, n. 7, maio 1999. Disponivel em <http:// www.ehu.es/zer/hemeroteca/pdfs/zero8-13-minguez.pdf>. Acesso em: 12 Jun. 2014.

MOEN, Darel R. News Paper Layout \& Design. Iowa: Iowa State University Press/Ames 2000

NORA, Pierre. Entre a Memoria e a História: a problemática dos lugares. Projeto História (10): 7-28, 2003.

MORISON, Stanley. Letter Forms. London: Hartley \& Marks Publishers, (1963) 1997. NEEDHAM, Paul. What's in a (Yale) Typeface? Yale Daily News (on line), 15 de Abr. 2008. Disponível em: <http://yaledailynews.com/blog/2008/04/15/whats-in-ayale-typeface/>. Acesso: 16 Abr. 2014

NOORDZIJ, Gerrit O Traço. Teoria da escrita São Paulo: Editora Blucher, 2013

OLINS, Wally. El Libro de las Marcas. Barcelona: Editorial Océano, 2009.

OLINS, Wolff. The New Guide to Identity. How to create and sustain change through managing identity. Hampshire: Gower, 1995.

OVINK, W. G. Legibility, atmosphere-value and forms of printing types. Leyden: A. W. Sijthoff's uitgeversmaatschappij N. V., 1938

OXFORD Advanced Learner's Dictionary. Encyclopedic Edition Oxford: Oxford University Press, 1992
PEÓN Ana Luísa. Sistemas de Identidade Visual Rio de Janeiro: $2 A B, 2003$ PETROBRAS. Estratégia. Missão e Visão 2030. Disponível em: <http://www.petrobras. com.br/pt/quem-somos/estrategia/>. Acesso em: 02 Fev. 2015.

PINGMAG. Erik Spiekermann - typography and design today. Entrevista de 3 de Outubro de 2005. Disponível em: <http://pingmag.jp/2005/10/31/erik-

PFFENBERGER, A. T.; FRANKEN, R. B. A Study of the Appropriateness of Type Eaces. Columbia Univ; Nova York University, Journal of Applied Psychology Vol. 7, p. 312-329, 1923.

PORCHEZ, J. François. Thoughts on the craft. In: RAULT, David (org.). Jean Francois PORCHEZ L'Excellence Typographique. Atelier Perrousseaux: Paris, 2014. Métro Type. Typo magazine 8. Typo: Republica Tcheca, Edição Abril de 2004 Disponivel em: <http://www.svettisku.cz/buxus/generate_page.php?page Parisine. Typofonderie, 2002. Disponível em:
gazette/post/parisine/>. Acesso em: 15 jan. 2015 .

POYNOR, Rick. The Guardian's New European Look. The Design Observer. Londres 2005. Disponivel em: <http://designobserver.com/feature/the-guardians-new-european-look/3757/>. Acesso em: 02 jan. 2015 .

RAULT, David (org.). Jean Francois PORCHEZ L'Excellence Typographique. Atelie Perrousseaux: Paris, 2014.

20 RATP. A Group in a Glance. Disponível em: <http://www.ratp.fr/en/ratp/c _5007/ presentation/>. Acesso em: 18 Jan. 2015

RE, Margaret. Typographically Speaking: The Art of Mathew Carter. Maryland

REHE, Rolf E. Typography: how to make it more legible. 1976.

25 How Expressive is Your Type. Design Journal, no 104, 2007

RICOEUR, Paul. A Memória, a História e o Esquecimento. Campinas: Ed. Unica,mp, 2007

RIJKSMUSEUM. History of the Rijksmuseum. 2014. Disponivel em: <https://www. rijksmuseum.nl/en/organisation/history-of-the-rijksmuseum > . Acesso em: 12

RÖGENER, S; POOL, A; PACKHÄUSER, U. Branding with Type, How Type Sells. California: Adobe Press, 1995.

SHAW, Paul. The Nomenclature of Letter Forms: a brief review of the literature. 2014. Disponivel em < http://www.paulshawletterdesign.com/2014/06/ 2014. Disponivel em < http://www.paulshawletterdesign.com/2014/06/
the-nomenclature-of-letter-forms-a-brief-review-of-the-literature/>. Acesso em 21 Out. 2014.

35 SCHWARTZ, Christian. Creative Characters, the faces behind the fonts. Edição 4, Outubro 2007. Disponivel em: < https://www.myfonts.com/newsletters/ 
SCHWARTZCO Inc Guardian sd Disponivel em: <http//wwwwchristianschwartzcom/ ol guardian.shtml >. Acesso em 18 Jan. 2015

SHAW, Paul. An interview with Matthew Carter. Cincinnati: Print magazine, 2011. Disponivel em: $<$ http://www.printmag.com/interviews/an-interview-withmatthew-carter/>. Acesso em: 21 Jan. 2015.

SOUZA LEITE, João de (org) A A Herança do Olhar. O design de Aloísio Magalhães Rio de Janeiro: Artviva, 2003.

_. Personalidade Corporativa e Identidade de Nações. D2B - Design to Brandin N. 7, pp. 20-29. Porto Alegre: GAD, 2011.

SPENCER, Herbert. The Visible Word. New York: Hastings, 1969

SPIEKERMANN, Erik; A Linguagem Invisivel da Tipografia. São Paulo: Blucher, 2011. Nokia Typograpfy. (apresentação da família completa). 2002. Disponível em: hhttp///spiekermann com/en/nokia-sans-character/> Acesso em 28 Out 2014

SMEIJERS, Fred. Type Now. A manifesto. Londres: Hyphen Press, 2003. Counter Punch. Making type in the sixteenth century designing typefaces now. London: Hyphen Press, 1996.

STIFF, Paul. Look at me! Look at me! (what designers want) (1993). In BIERUT, M.; DRENTTEL, W:; HELLER, S:; HOLLAND, DK., Looking Closer. Allworth Press, 1997

STÖCKL, Hartmut. TYpography: body and dress of a text - a signing mode between language and image. Visual Communication 2005 4: 204. Disponível en
<http://vc.sagepub.com/content/4/2/204 >. Acesso em: 23 Mar. 2014 .

TSCHICHOLD, Jan. The Principles of the New Typography. In HELLER, Steven; MEGGS, Philip B. Textos on Type - Critical Writings On Typography. New
York: Allworth Press, 2001. p. 115-128.

TYPETOGETHER. TYpography Made to Fit. Typetogether's primer about lettering, font usage and tailored typography. 2014

La voz de Almería Disponivel em: < http://www.type-togethercom/index php?action=portal/viewContent\&cntId_content=3124>. Acesso em 28 Dez 2014

TYPOFONDERIE. Parisine Plus. 2015. Disponível em: < http://typofonderie.com/fonts/ parisine-plus-family/\#details $>$. Acesso em: 27 Jan. 2015

TYPOPHILE. Typeface definition. <http://typophile.com/node/16843>. Acesso em: 16 Out. 2014

TWYMAN, Michael. Articulating Graphic Language: A Historical Perspective. In Merald E. Wrolstad and Dennis F. Fischer (Eds.). Toward a New Understanding . 1986.

- A Schema for the study of graphic Language. In Kolers., P.A. WROLSTAD, M. E. e BOUMA, E. (ed.), Processing of Visual Language, Vol. I. Nova York: Plenum Press, 1979. pp 117-150.

The Graphic Presentation of Language. Information design journal vol. 31982
UNGER Gerard Legible? Emigre 232 1993. In BIERUT M. DRENTTEL W: HELLER, S: HOLLAND, DK. Looking Closer. Allworth Press, 1994

. While You're Reading. New York: Mark Batty Publisher, 2007.

VAN LEEUWEN, Theo. Typographic Meaning. Visual Communication, 4: 137, 2005.

05 VILLAS-BOAS, André. Identidade e Cultura. $3^{\mathrm{a}}$ ed. Teresópolis (RJ): 2AB, 2009.

WALKER, Peter. Font Tuning: a review and new experimental evidence. Reino Unido Lancaster University, 2007.

WALKER ART CENTER. Architecture and Design. Disponível em: <http://wwwwwalkerart. org/architecture-design>. Acesso em: o9 Jan. 2015.

10 WARDE, Beatrice. The Crystal Goblet. Sixteen Essays on Typography. Edição de Henry Jacob. Cleveland e Nova York: 1956

. Print Should be invisible. In: McLEAN, R. Typographers on Type. New York: Lund Humphries, [19323]. p. 73-78. 1995.

WHEELER, Alina. Design de Identidade da Marca. $2^{a}$ edição. São Paulo: Bookman, 2008.

WILKINSON, Alex. A Man of Letters. Matthew Carter's life in type design. The New Yorker, 2005, pg. 56. Disponivel em: <http://www.maryellenmark.com/text/ magazines/the\%20new\%20yorker/907S-000-046.html>. Acesso em: 05 Jan. 2015

YALE UNIVERSITY a. History. Disponível em: <http://www.yale.edu/about/history. html>. Acesso em: 09 Jan. 2015.

20 b. Yale Identity. Disponível em: <http://printeryale.edu/ >. Acesso em: $10 \mathrm{Jan} .2015$ c. Office of the University Printer. c. Disponivel em: <http://www.yale.edu/ printer/typeface/typeface.html\# >. Acesso em: $10 \mathrm{Jan} .2015$

ZAPATERRA, Yolanda. Typography: electronic Workshop. Mies: Rotovision, 1999.

ZAPE, Herman. Histórias de Alfabetos - A autobiografia e a tipografia de Hermann Zapf. São Paulo: Ediçōes Rosari, 2005.

\section{Manuais de Identidade Visuais e Style Guides on line:}

BRITISH COUNCIL. Disponível em: <http://brand.britishcouncil.org/visual-identity/>. Acesso em: 30 Jul. 2014.

CBS. Disponível em: <http://fontsinuse.com/uses/6002/cbs-identity-1960s>. Acesso em: 16 Dez. 2014

BRITISH RAIL.Disponível em: <http://www.doublearrow.co.uk/manual.htm>. Acesso em: 29 Set. 2014.

ROYAL COLLEGE OF ART.Disponivel em: < http://www.rca.ac.uk/students/unitytangled-world-corporate-identity-france-/>. Acesso em: 28 Set. 2014

DIE BUNDESREGIERUNG. Disponível em: <http://styleguide.bundesregierung.de/ Webs/SG/DE/>. Acesso em: 29 Jul. 2014. 
UNB. Disponível em: <http://www.marca.unb.br/>. Acesso em: 06 Jan. 2015.

YALE UNIVERSITY. The Yale Brand. The trademark licencing program. Office of University Printer, 2013. Disponível em: <http://licensing.yale.edu/yale-brand Acesso em: 11 Nov. 2014.

YALE UNIVERSITY. Editorial Style Guide for Yale University Publications. Office of University Printer, 2011. Disponível em: < http://www.yale.edu/printer/ bulletin/style/Editorial_guide.pdf>. Acesso em: 11 Jan. 2015.

The Yale Brand. The trademark licencing program. Office of University Printer, 2013. Disponível em: <http://licensing.yale.edu/yale-brands.

- Yale University Campus Signage. Exterior Sign System. Office of Univers Pleso

\section{Manuais de Identidade Visuais impressos}

\section{Cauduro/Martino}

Sistema Metrô de São Paulo - Planejamento Urbano, 1972.

Volumes I, II e III. (Tese de Doutorado)

Souza Cruz, 1983

Mangels, 1986

Credicard/Mastercard, 1987.

FIESP/CIESP, 1989. Volumes I e II.

Banco do Brasil., 1994. Volumes I e II.

Unibanco, 1995.

Caesar Park Hotels \& Resorts, 1996

Embrapa, 2000.

Plilkington/Blindex, 2001

\section{Websites}

AXE TIMES. http://www.tobiasbecker.org/cms/axe-times/>. Acesso em: 21 Nov. de 2014

_http://fontsinuse.com/uses/8063/civic-city-cahier-series>Acesso em: 21 Nov. de 2014 —. http://www.bedfordpress.org/current-publications/civic-city-cahier-1/3.
Acesso em: 21 Nov. de 2014.

CUSTOM FONTS <https://www.typotheque.com/licensing/corporate> Acesso em: 14 Set. 2014.

_ _https://www.typotheque.com/fonts/custom_types. Acesso em: 14 Set. 2014

__http://www.nytimes.com/2008/10/26/nyregion/26dorfsman.html>

- Acesso em: 14 Set. 2014

_ $<$ http://www.lucasfonts.com/custom/>. Acesso em: 16 Out. 2014

<http://www.fonts.com/info/services/custom-fonts>. Acesso em: 16 Out. 2014

_. hhttp://characters.nl/customtype/custom-type-options $>$. Acesso em: 28 Set. 2014

15 __ _http://www.typography.com/custom/ >. Acesso em: 27 Set. 2014

— $<$ http://www.monotype.com/services/font-design/custom-design > Acesso em: 02 Out. 2014

.chttp://www.fontsmith.com/services/custom-font-design>. Acesso em: 11 Out. 2014 _ <http://www.type-together.com/customtype>. Acesso em: 12 Out. 2014.

20 <http://www.type.co.uk/index.php?p=Corporate_ID>. Acesso em: 17 Out. 2014 _. _http://www.type.co.uk/index.php?p=Custom_Fonts>. Acesso em: 15 Out. 2014. _.http://www.metadesign.com/clients/audi . Acesso em: 17 Out. 2014 EYE MAGAZINE http://www.eyemagazine.com/blog/post/more-platforms-foreditorial-design>. Acesso em: 13 Nov. 2014

HOEFLER\&CO. Disponível em: <http://www.typography.com/>. Acesso em: 14 Jan. 2015 LINOTYPE. Disponível em: <http://www.linotype.com/>. Acesso em: 12 Jan. 2015. LUCAS FONTS. Disponível em: <http://www.lucasfonts.com/>. Acesso em: 12 Jan. 2015. MONOTYPE. Disponível em: <http://www.monotype.com/services/font-design/ custom-design>. Acesso em: 12 Jan. 2015.

RATP <http://www.ratp.fr/en/ratp/c_5043/metro/>. Acesso em: 11 Nov. 2014.

http://www.ratp.fr/en/ratp/__ 108535/_-long-history/>. Acesso em: 11 Nov. 2014

THE GUARDIAN <http://www.theguardian.com/profile/markporter>. Acesso em: 03 Jan. 2015.

_.http://www.theguardian.com/gpc/story-of-the-berliner>. Acesso em: 11 Nov. 2014

_ _http://www.theguardian.com/uk>. Acesso em: 10 Nov. 2014. 
THE GUARDIAN <http://www.theguardian.com/gpc/berliner-format> Acesso em: 10 Nov. 2014.

_. hhttp://www.theguardian.com/theberliner/story/o,,1566047,00.html Acesso em: 21 Jan. 2015.

— $<$ http://www.theguardian.com/gnmeducationcentre/archive-educationalresource-february $>$. Acesso em: 14 Nov. 2014.

. http://wwwmyfonts.com/newsletters/cc/200710 html> Acesso em: 14 Nov. 2014 shttp://www.theguardian.com/gnm-archive/2005/oct/15/2>. Acesso em: 17 Nov. 2014 . _http://www.theguardian.com/gnm-archive/2005/aug/19/1>. Acesso em: 17 Nov. 2014

<http://www.christianschwartz.com/guardian.shtml>. Acesso em: 17 Nov. 2014.

_.http://archive.rogerblack.com/blog/next_news_typography>. Acesso em: 18 Nov. 2014.

_. _http://www.theguardian.com/media/gallery/2011/may/05/the-guardian-190thanniversary-pictures\#img-14>. Acesso em: 18 Nov. 2014.

WALKER <http://wwwwwalkerart.org>. Acesso em: 11 Nov. 2014

GLOSSÁRIO

VISUAL

Acesso em: 11 Nov. 2014.

. http://www.youtube.com/watch?v=p4qxud20xg8>. Acesso em: 11 Nov. 2014.

_ _http://typostitch.com/2013/04/01/00-matthew-carter-walker-1995/>. Acesso em: 21 Jan. 2015.

_.http://design.walkerart.org/detail.wac?id=2098\&title=articles > Acesso em: 22 Jan. 2015.

YALE <http://www.yale.edu/printer/typeface/history.html>. Acesso em: 22 Jan. 2015.

___ _http://www.yale.edu/printer/typeface/typeface.html>. Acesso em: 13 Fev. 2015. .<http://pt.scribd.com/doc/106574480/The-Yale-Typefaces. Acesso em: 13 Jan. 2014. <http://identity.yale.edu/>. Acesso em: 13 Jan. 2015. 
Anatomia dos caracteres tipográficos

Este quadro é uma síntese visual de diversas amostras e textos reférentes ao
tema coletados desde o início dos anos 1990, baseada na experiência pessoal

e na revisão bibliográfica realizada pelo designer e historiador do design

norte americano Paul Shaw (2014), reúne pesquisas de diversos autores,
desde tipógrafos e historiadores à ilustradores e bibliófilos. PEVISĀO FEV
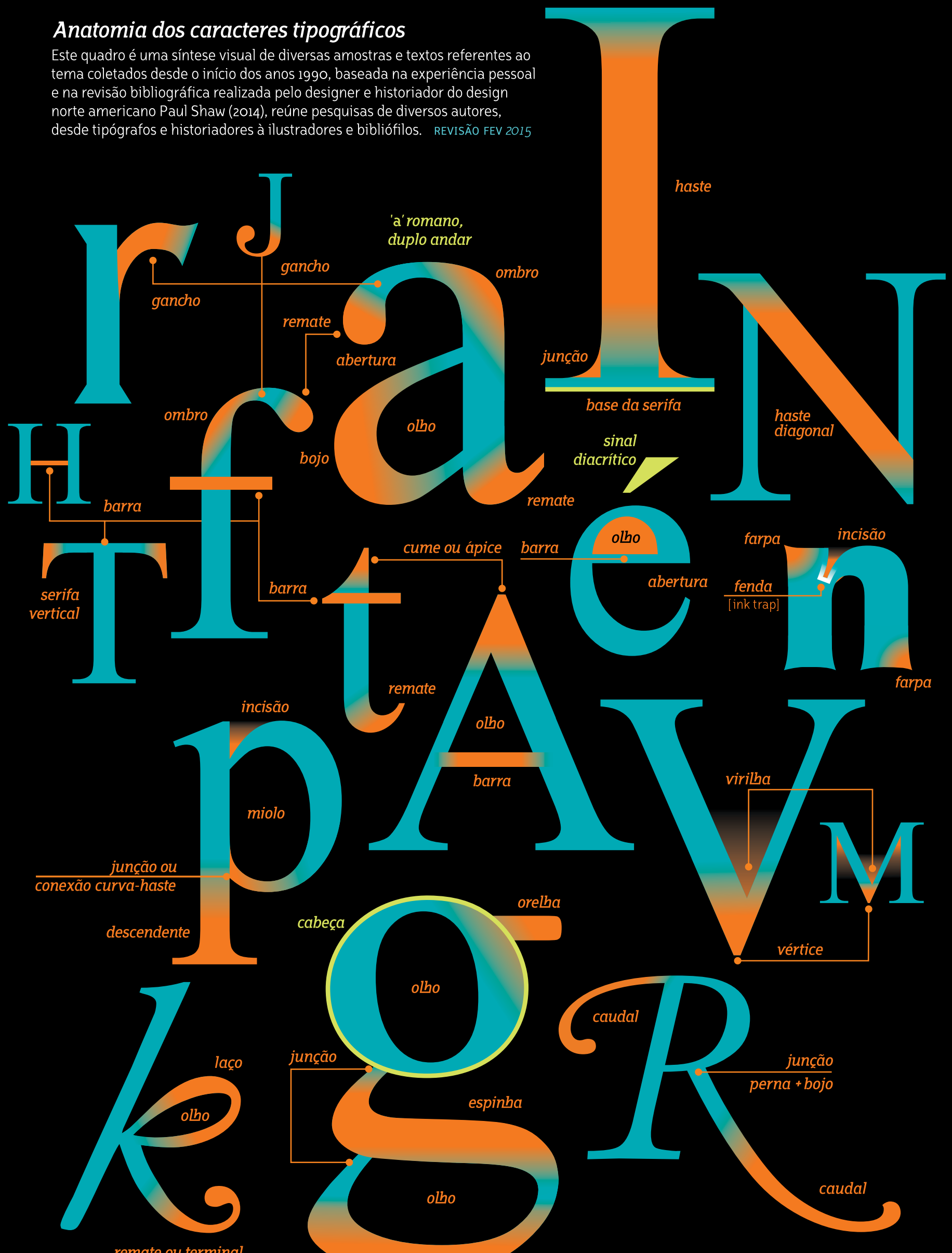

remate ou terminal
curvado

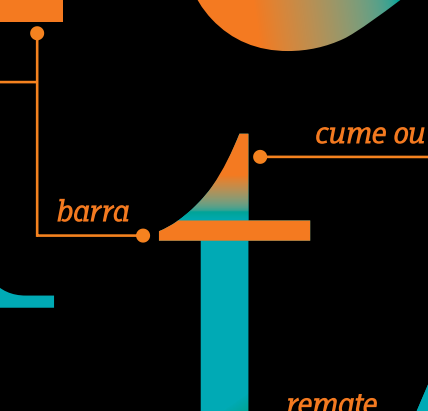

inice barra olbo
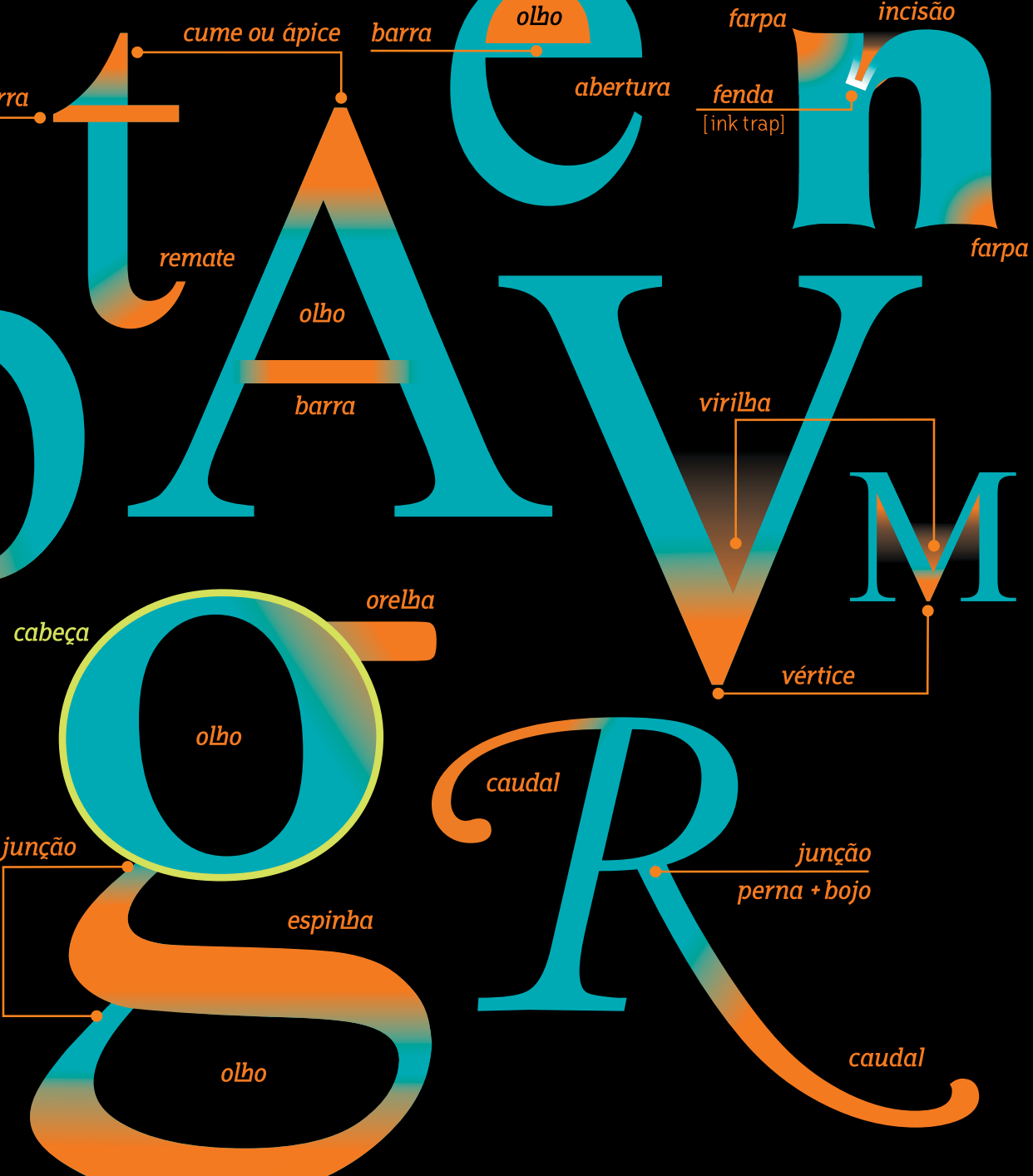

serifa transitiva
ou remate de
entrada
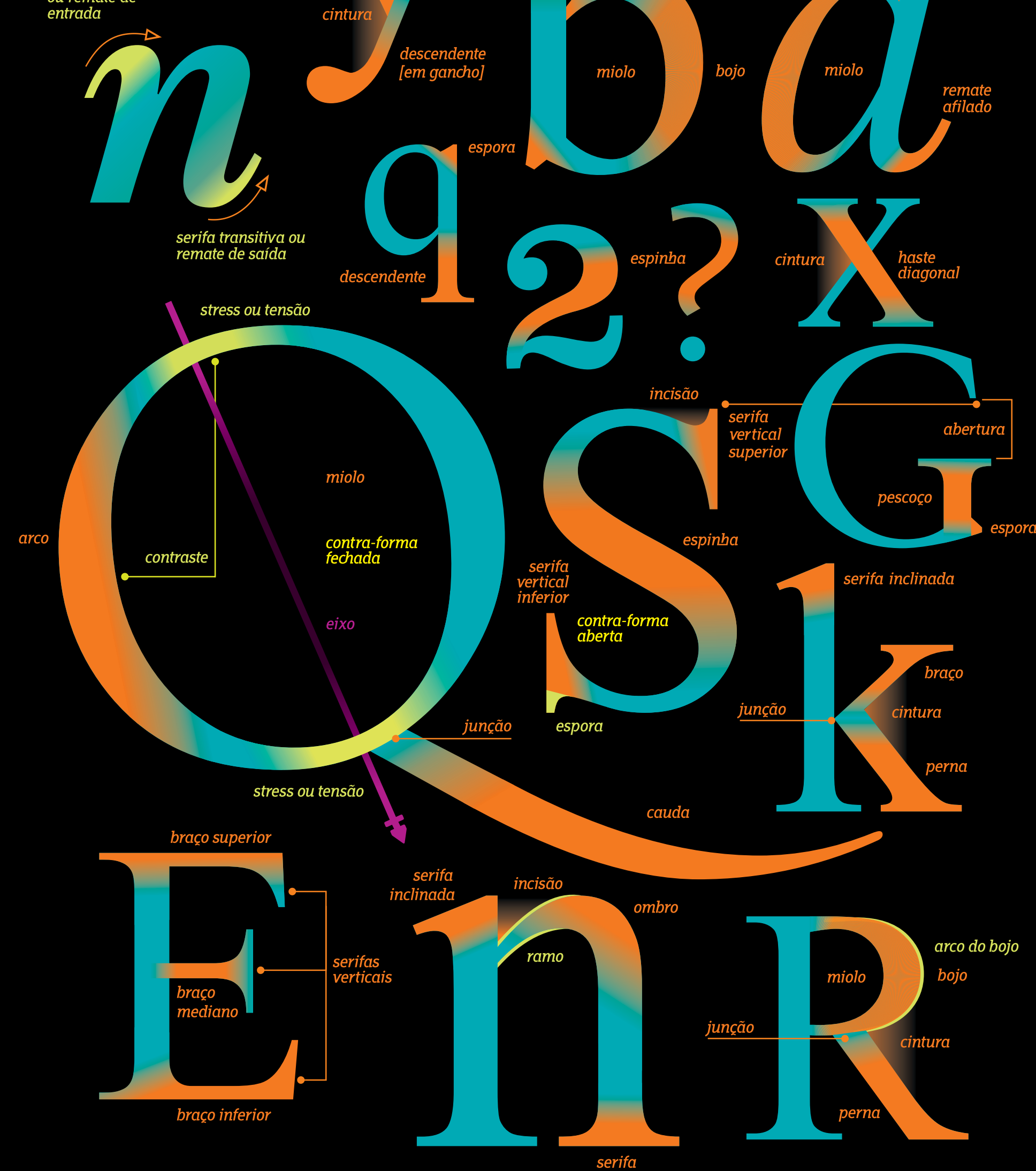
Alinhamentos

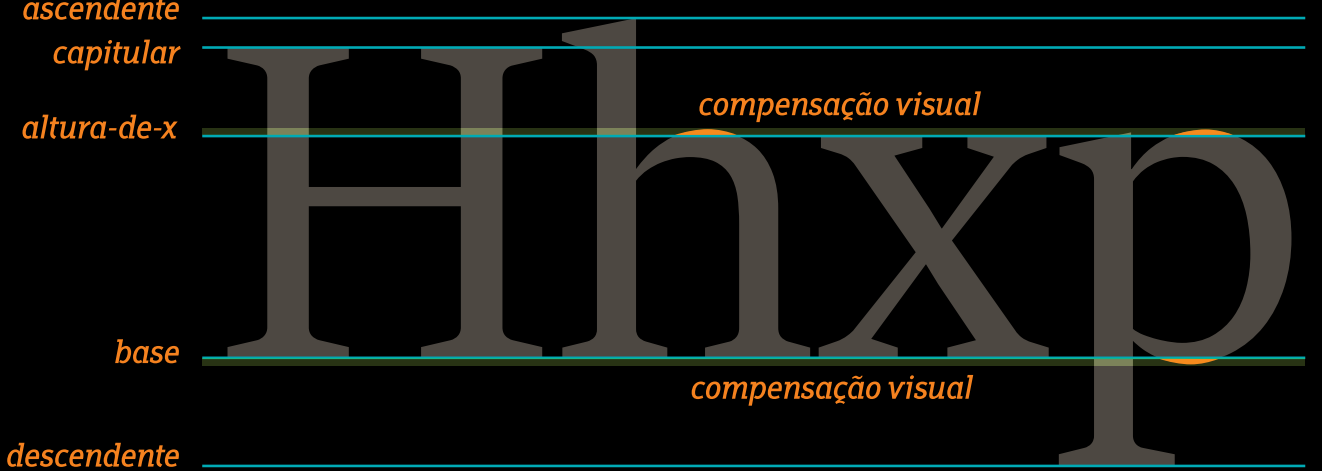

descendente

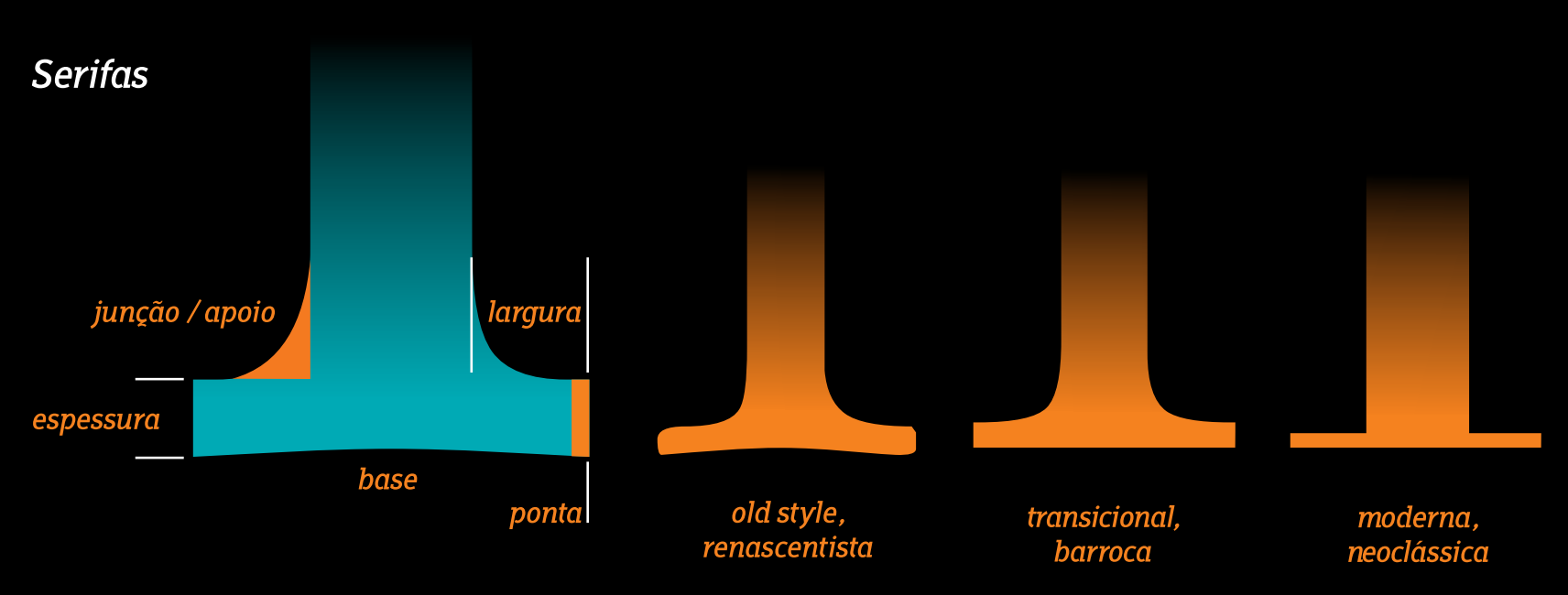

Remates
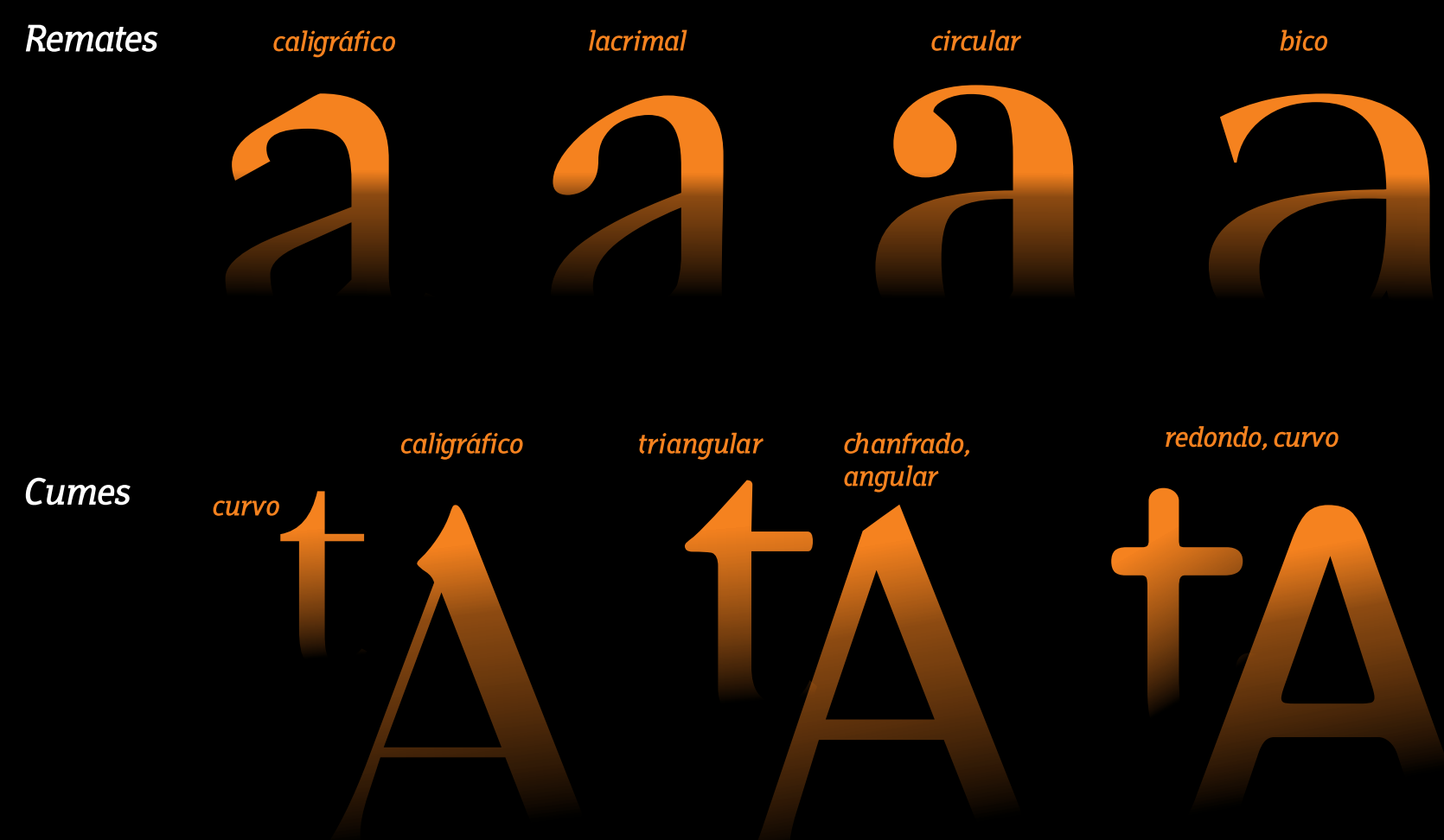

\section{1n日n-1}

Proporção

Além da relação entre
alturara e largura do caractere, as proporçôes ainda
consideram a relação entre a altura-de-x e a ascendente.

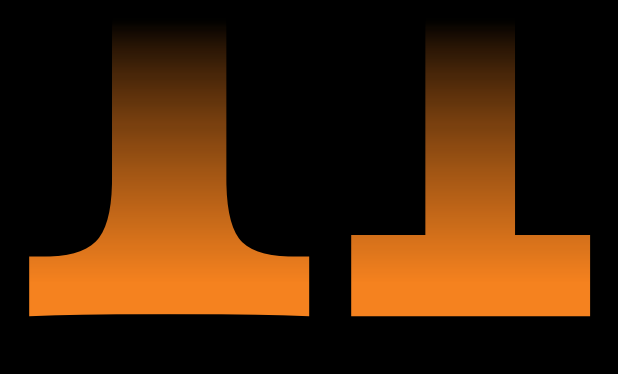

egipciana, quadradc,

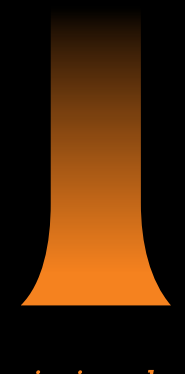

insinuada

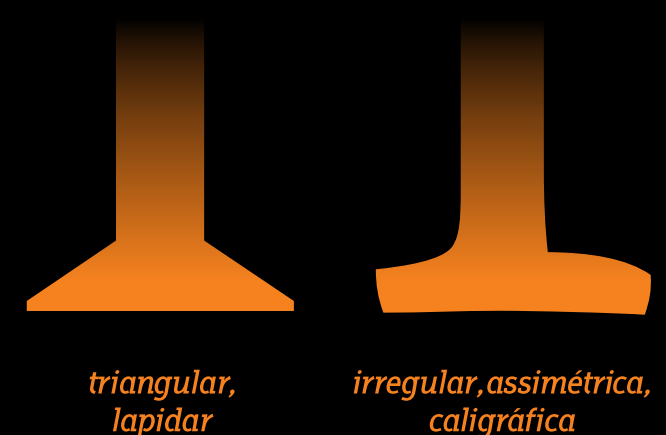

caligráfica
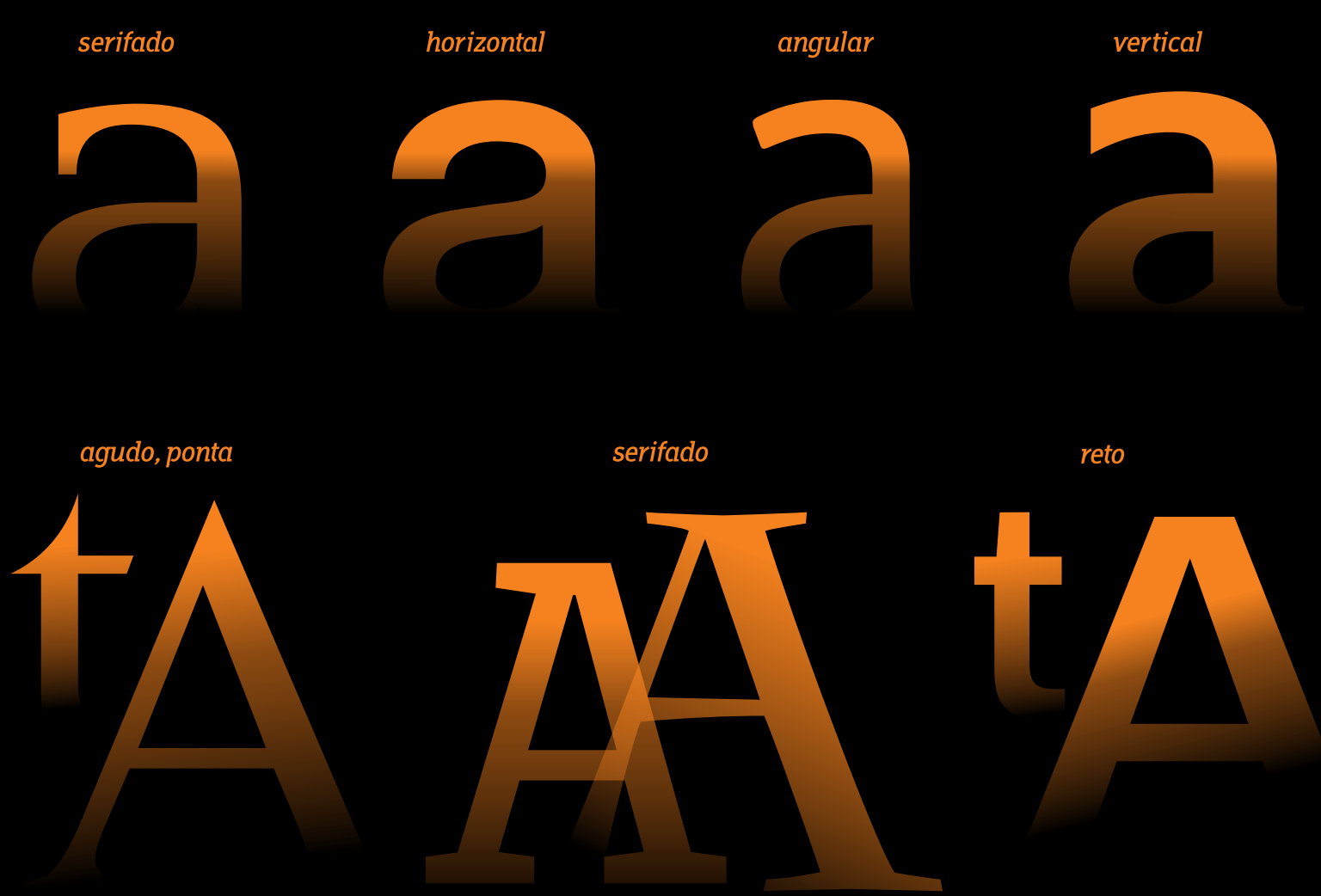
ANEXO I

Entrevista online com

Matthew Carter

ANEXO II

Entrevista gravada com

FabioHaag e Fernado Caro Dalton Maag, Brasi 


\section{ANEXO I}

Os designers Jean F. Porchez, Christian Schwartz e Paul van der Laan, se dispuseram previamente a responder o questionário, mas não tiveram condições de fazê-lo no momento necessário. O designer Bruno Maag sugeriu que a entrevista fosse feita com seus dois designers barsileiros, por terem se envolvido mais profundamente com o projeto da Petrobras Sans (ANEXO II). O questionário original é formado por cinco questões descritivas, abordando o processo de elaboração da fonte, o briefing requerido, referências para a conceituação do design, o design da fonte e a relação da tipografia como a identidade; uma questão de escolha em uma escala de valores; e uma questão com múltipla escolha.

A Entrevista com Matthew Carter, foi realizada em 08 de dezembro de 2014, mediante questionário enviado por e-mail. Outras informações complementares foram coletadas pessoalmente por ocasião de sua visita ao país para palestra. As respostas apresentadas a seguir, são as únicas que o designer pode responder.

\section{YALE Typeface}

1. In the YALE design, what were the most relevant guidelines in the briefing?

MC: I was commissioned by the Printer to the University to design a typeface wit wo versions, one for general use, the other for signs on campus. The generalpurpose Print face was later subdivided into two versions, Design and Admin. There were a few differences in the character set, for example the Design face had f-ligatures and old-style figures, while the Admin version had no ligatures and lining figures.

2. What kind of structural work was done on Bembo and how that helps Yale identity?

MC: Bembo was not involved, except that it had been used by the University at an earlier date and therefore set a precedent for an Aldine design.

3. How did you "translate" the briefing information into letter shapes?

MC: The briefing information contained no references to letter shapes. My proposal for an Aldine design was accepted as a whole, not on a letter by letter basis.

\section{WALKER Typeface}

1. In WALKER, the process was built by presentig to all staff some ideas, that should be discarded. Just an initial point to generate discussion. You taked to many people about it What kind o people were they (besides $K$ Halbriech). what questions did you do and what were the responses?

MC: Most of my conversations were with the small design staff at the Walker Art Center, especially with Larie Haycock Makela, the design director I a center, with other curators. I don't remember the details of the conversa at this distance of time.

2. In the Walker design, what were the most relevant guidelines in the briefing?

MC: I was given very little guidance as to the style of the typeface. Kathy Halbreich said: "Nothing too spiky."

3. The 'mix' of Egyptian serifs intend to create a postmodern taste, reviving th victorian posters in a contemporary design?

MC: Only one of the set of "snap-on" serifs was in the Egyptian style of slab-serif. There was no reference to Victorian posters.

4. How did you "translate" the briefing information into letter shapes?

MC: I was given a very free hand in the briefing. As the design developed I sent trial fonts to the designers at the Walker who tested them. The typeface took shape as the result of this collaboration. 
LC: Luciano Cardinali, entrevistador

EH: Fabio Haag, diretor de desenvolvimento de Negócios (2008)

FC: Fernando Caro, coordenador de equipe de design (2011)

LC: Fábio, esse é o questionário completo, gostaria que você respondesse na medida do possível, a primeira questão é sobre o processo de criação, como é, por onde começam, se existe um padrão ou varia de projeto para projeto?

FH: Existe um padrão sim, o projeto da Petrobras iniciou há três anos. Hoje, já temos o processo mais documentado. $O$ processo é basicamente dividido em quatro etapas. A fase inicial, nós chamamos de Ideation. É a fase de geração de ideias, quando começamos, geralmente, com um número limitado de caracteres, em torno de 7 a 9, onde há a exploração de conceitos, no caso d Petrobras foram 42 opções diferentes com poucos caracteres. [...]

C: Antes dessa fase inicial do projeto, o cliente fornece algumas informações daquilo que deseja, certo?

FH: Exatamente. O nosso trabalho e muito voltado às empresas de design, somo chamados quando já tem um briefing bem estipulado, já com definições de palavras-chave e atributos de marca. No caso da Petrobras, entramos numa fase em que a Identidade Visual ainda estava sendo definida a junto à 20 direção da Petrobras. A agência LED Project tinha quatro caminhos para a Identidade, isso explica porque fizemos as 42 ideias, foram "tiros para todos os lados", uma palavra em 42 versões, o objetivo dessa fase inicial é esse mesmo. testar a maior variação possível de ideias dentro do escopo do briefing.

Das 42 opç̃oes, a agência (The Led Project), e não o cliente selecionou seis opçōes, (jun/2011); depois reduzimos a duas, que foram refinadas e expandidas por nós. Agora temos um conceito de design e a expansão consistena etapa que chamamos de Design Concept. Antes tínhamos uma ideia, agora trabal ques em um conceito de design. Nessa fase expandimos o mesmo concito das duas opcões, para mas letras. Trabahamos com cerca de 25 letras incluindo duas opços par maindo alguns números e pontuaçá básica. Consiste basicamente em pegar aquelas cle expan en Ele pode não funcionar ao expandi-lo para mais letras, inclusive em pesos

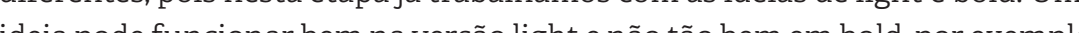
ideia pode funcionar bem na versão light e não tão ben em bold, por exemplo.

C. A versão itálica entra ai também?

H. Itálicos não. Entram bem depois. Se não for fundamental para o projeto, entra só depois.

LC. Até aqui, esses testes com pesos e mais letras são apenas no design das letras ou testes de espaçamentos e mancha tipográfica em textos?

FH. Não exatamente..
FC. Mas testamos as poucas letras em palavras e em textos pequenos.

FH. A terceira etapa, chamamos de Concept Refinement, ou seja, o refinamento do conceito. Depois que foi apresentado ao cliente, do cliente aprovar, alterações sutis ou radicais podem ser feitas. No caso da Petrobras, alteramos um pouco as terminações da fonte. Esta etapa é bem flexível, pode ser que não ocorra: e pode-se pular diretamente para a etapa seguinte, a Execution ou mplementação. Concept Refinementépara fechartodo conceitoedecisões de design pesos, estilo, caracteres-chave A Petrobras sentiu a necessidade de

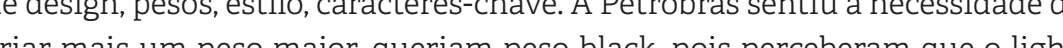
(ciar O liente aina pode suresentar um dispositivo de tela que é fundamem. Ocliente inda pode apesentar um disposivo de tela queefundantal -

Apresentamos seis ideias iniciais (etapa Ideation), em junho de 2011, seguida de outra apresentação em juh ho em que expandimos dois conceitos com term naçôes. Na realldade o cliente não participou muito neste momento, foil mais com a LED, que fizeram as escolhas, usaram as fontes aplicando-as em layouts.

LC: Então a LED testou em layout as 6 versões?

FH: $\operatorname{Sim}$

FC: No caso da Petrobras o teste de peso foi feito somente após a aprovação total do conceito. Hoje já fazemos teste de peso, mais leve e mais pesado, enquanto desenvolvemos o conceito. É comum a agência solicitar os conceitos de fontes para teste em layouts e vice versa, eles também enviam os layouts para nós aplicarmos as ideias em ambiente contextualizado e verificar a pertinência das opções. Fazemos a geração de textos para visualização pelo site adhesion e enviamos para aplicação junto com fotos e os outros elementos da identidade para verificar a pertinência do conceito e das opções.

LC: Esses layouts são completos, com fotos, diagramação?

FC: Sim, um fundo com os conceitos escolhidos para a identidade corporativa

FC: Hoje fazemos esses testes antes... Apesar de não estarmos certos se será aquele black exatamente já fazemos testes de pesos aproximados para verificar o conceito e para termos uma noção de família.

LC. Nessa etapa do Design Concept, os testes de pesos são feitos em mais de uma opção, ou apenas naquela já definida?

FH: Sim... Vou compartilhar a minha tela para você ver as versões, veja os quatro pesos light, a comparação do regular com o bold, o mesmo regular com outro bold. [...] Veja só a quantidade de páginas que esse documento tem, são 89 páginas!

FH: A ideia do conceito, nesse ponto, é ter as características básicas, com minúsculas, maiúsculas, alguns números e a pontuação, ou seja, grande parte do parâmetros já está definida ali.

C: Sem dúvida, as diagonais, curvas, bojo... Na fase da implementação vocês fazem ajustes mais técnicos da fonte?

FH: Não, na implementação não ocorre mais nenhum ajuste de conceito. É “baixar cabeça" e executar. É expandir o conceito para todo o mapa de caracteres, todos os idiomas e todos os estilos. Não tem mais imput criativo ou ajuste em uma letra 
caso contrário complica tudo. Por isso a etapa de Concept refinement existe, éo alinhamento final com o cliente de todo conceito. Porque depois não tem mais como alterar, depois é engenharia e o hinting, que é feito na fase final.

FC: No caso da Petrobrás não teve hinting.

LC. O cliente aprova as decisões e conceitos em que momento? Na fase do Concept Refinemet, as opções são apresentadas e ele aprova uma opção, certo?

FH. Exatamente Na verdade ele aprova em cada momento na Ideation depois no Design Conc. Né importante deixar clara essa etapa do Execution, en no Design Concon aqui a validação final da fonte e outros processos.

C. O que é exatamente a "validação" da fonte?

EC: É um processo de pequenos ajustes, usamos programas acessórios para checar se a fonte está funcional. Depois do design, trabalhamos com a engenharia da fonte, algumas informaçōes que só são acessadas por um programa que própria Dalton Maagdesenvolveu para checar a funcionalidadeda fonte; temo programas de validação para a fonte funcionar no Office, na questão de assinatura digital. Depois que a fonte está funcionando fazemos o hinting. Mesmo assim o trabalho pode voltar e passar por processos de validação novamente. L: Vocês usam programas como Volt, AFDK?

FC: Não usamos o AFDK, usamos um editor avançado para o funcionamento da fonte, são ferramentas proprietárias (não revelado o nome e a função), algun ajustes no VTT e no Volt.

LC: Como vocês classificariam uma fonte customizada? O Bruno Maag disse algo mais genérico, que uma fonte customizada é aquela feita a partir do zero e as outras são apenas modificações ou extensões de trabalhos já existentes.

FH: Acho difícil classificar, é uma questão de origem da palavra inglesa custom. Para nós, tudo é custom, ou seja, modificação.

LC: Eu diria que há diferença entre modificação e "feita sob medida" . Basicamente a tipografia customizada é feita do zero. Modificada seria alterada em vários níveis de complexidade.

FH: Para nós tudó́modificação desde acrescentar novos caracteres novos pesos

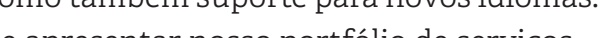

LC: Por exemplo, a extensão de uma família. O cliente já tem um estilo e quer expandir para outros pesos

E: A tradução de custom seria: feito sob medida. Nesse caso, seria o exemplo de um cliente precisar de um peso sob medida, algo entre o peso regular e medium. Algo muito específico

FH: É um caso extremo. Dentro do nosso portfólio de serviços, isso também seria uma modificação, desde expandir para mais pesos, adequação para outros idiomas, complementação de caracteres, para nós é sempre modificação.

LC: Vocês considerariam chamar de complementação o caso de, um cliente que Já tem alguns caracteres que compõem um logotipo, quer expandir para uma fonte completa?

FH: Para nós tudo é tudo é modificação.
LC: Otimização para tela, correção de espaçamento sem, ser o hinting..

FH: Sim, é modificação.

LC: Vamos agora falar sobre briefings. Quero só pontuar que o foco da minha pesquisa é identificar, registrar, elucidar como os aspectos subjetivos, emocionais solicitados pelo cliente/ou inerentes ao projeto são convertidos em aspectos gráficos na fonte. Que tipo de imput o cliente deu que resultou na forma da fonte da Petrobras?

FH: Um dos conceitos solicitados era Acessibilidade, no sentido de atingir maior a conceicia possivel desde o frentista ao investidor internacional e a diretoria corporativo até numa peça sobre festa folclórica do nondeste, a fonte Petrobras tera usos tro variados, descle uma etiqueta na bomba de gasolina Petrobras teria usos táo variados, desde uma etiqueta na bom ba de gasolina

Outra solicitação era ser livre de modismos, ter uma durabilidade 10 a 15 anos, não ficar datada muito rápido; Expressiva (ponto de atenção, se reconhecida como Petrobras. Ao olhar para fonte, as pessoas deveriam dizer: isso é a Petrobras, torná-la única. Outra solicitação técnica pedia que fosse levemente condensada. Ser ligeiramente condensada representa uma economia de espaço. Pensando na escala da Petrobras, se for algo com $3 \%$ mais econômica que a Helvética por exemplo, representaria um ganho gigantesco em economia na quantidade de páginas de relatórios.

LC: Algum aspecto mais subjetivo foi requisitado como, por exemplo, a font deve ser "enérgica" ou "ativa"?

FH: Um aspecto importante deve ser citado. Um grande problema da Petrobras é a vasta quantidade de fornecedores. As licitações são abertas para grande maioria dos materiais, site, relatórios anuais... Cada fornecedor quer "imprimir" a sua identidade, quer marcar o seu estilo; com isso a identidade tipográfica e a própria identidade visual da Petrobras estava se diluindo. Uma das solicitações da LED era que a fonte deveria ter todas as ferramentas necessárias para que um designer não sinta a necessidade de trocá-la por outra, que ela funcionasse na diversidade de temas. Por isso, o itálico é tão diferente o projetamos para quando o designer quiser variar a fonte que usa

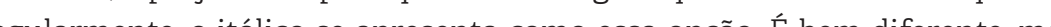
está dentro da mesma famélia

LC: Qual é a expressividade do itálico, é mais caligráfica? São os arremates?

FH: Sim, possui vários aspectos da herança caligráfica.

solicitado algum requisito técnico, como alguma open type feature específico?

FH: Sim, um bem específico. A nova identidade tem um elemento, uma barra, que está acima de todos os títulos, criamos uma feature que ao digitar três vezes 1, automaticamente é substituido por esse carac trabalho para quem trabalha com identidade.

35 LC: Como traduzir atributos subjetivos em formas?

H: Tentativa e erro. Temos uma percepção do que parece mais humano, o que se parece mais com tecnologia, é muito difícil de avaliar. Curvas mais quadradas geralmente são mais técnicas, mas há casos de curvas quadradas com aspecto 
humano... É na avaliação dos resultados que observamos esses atributos, po isso as 42 opções, o resultado depende da comparação e da concordância nos caminhos por todos os envolvidos.

FH: Comaparando a Petrobras Sans ea Helvetica, veja: a Helvetica é fria, tem um ar mais industrial, maiúsculas monoespacadas, as aberturas (E, S, a e) são muito fechadas já a Petrobras Sans tem traços mais humanistas, counters mais abertos Quando comparado com a Frutiguer, uma fonte sans humanistica o 'S' da Petrobras Sans tem uma base sólida mas nãoétão humano. Voltandoà coma comparaçao coma relvetica, reparamos que a Petrobras parece mais humana nas em comparação com a Trutger, que é super humana, a Petrobras San náo é táo humana assim. Esta é a beleza de uma fonte custom, pode-se criar un caninho entre uma Futiger e una Helvetica, un ajuste delicado entre os aspectos soft, humano, e do aspecto frio, técnico e pesado. A Petrobras Sans tem um esqueleto enigido, que transfere essa solidez.

LC: Se eu quiser me lembrar da Petrobras Sans, quais são os caracteres-chave, quais aqueles que mais conferem identidade à fonte?

H. 'R e KM maísculo. A Petrobras Sans usa frequente? do ' $\mathrm{K}$ ' não ser muito usado. Os algarismos 2, 3; o 'a', claro.

FC: O 'a' e o 'k' minúsculo. Remate curvo 'l' Q', 'k' junção curva e reta (braço curvo perna reta, junta-se numa barra horizontal.

LC: A barra do 't' tem uma inclinação.

FH: Usamos isso para facilitar legibilidade em corpos pequenos.

LC: No geral, você vê a tradição holandesa nessa fonte?

FH: Sim, teria uma certa herança dos holandeses.

LC: Quais fontes a Petrobras usava antes?

FH: Usavam muito a Helvetica e a Din

LC: Vocês usaram alguma referência histórica, da arquitetura, da cultura?

FH: Não, não buscamos nada nessa direção.

FC: O maior atributo brasileiro é ser amigável.

LC: O que faz uma fonte se tornar "icônica", o que leva uma fonte ser uma referência visual de uma ́́poca? Na opiña de vocês, é o fato de muitos teferencia vis de

FH: Questões técnicas são fortes, a Verdana foi adotada por questão funcional, fo desenvolvida para ter legibilidade em dispositivos de baixa resolução, projetada inicialmente como bitmapped...; a Helvetica, além de o seu design capturar a essência do seu tempo, foi usada em massa, por ser distribuída nas máquinas Monotype, em parceria com a Apple; impressoras e softawres vinham com a Helvetica. Ser acessível ao público eu acho que é o fator mais importante; da Univers, que foi lançada dois anos antes e náo teve tanto sucesso, sem tanta divulgação; A Comic Sans é uma fonte iconica por causa acessibilidad é disponível no Windows.

LC: Voltando um pouco mais, vou dar como exemplo as tipografias em estilo Art Déco, com suas proporções próprias, o deslocamento da linha média etc. Existem centenas de variantes com essas características. Como esse estilo?

FH: A tipografia é espelho do seu tempo, e a recorrência do uso.

LC: Qual o maior benefício que uma tipografia customizada pode trazer para uma marca?
FH. Em uma fonte customizada você tem controle total da expressão visual do projeto. É aquilo que a palavra taylored diz, você vai ao alfaiate e recebe uma roupa sob medida, de acordo com todas as suas "imperfeições" e a roupa cai feito uma luva.

O design exclusivo é cada vez mais importante, por conta da saturação da comunicacão: a tipografia corporativa é uma forma de entregar uma mensagem de marca de forma mais sutil. Tira a carga publicitária muitas vezes impositiva ao leitor. A marca está na tipografia, você escreve uma not́cí e Costumo dizer que qualquer coisa que voce escrever em Offici Bold sobre Costumo dizer que qualquer Do ponto devistaden

10.1 . Do potos de logistica de distribuçáo em sites ou dispositivos.

Do ponto de vista de técnico: criada para atender requisitos técnicos de novos ambientes, que uma fonte de pacote (varejo) não oferece, disponibilidade de aplicaçăo em diversos dispositivos de impressão como offset, papeis baixa qualidade de definição, celulares, tablets, TV, apps, e-readers etc.

LC: Do ponto de vista de Identidade, qual tipografia é a cara da empresa que representa?

FH: O logotipo da Caixa (Caixa Econômica Federal) tem um 'X' em relevo. Este relevo está sendo usado em outras letras maiúsculas, e olha que bacana, uma fonte corporativa, que só funciona em cor, usa um elemento direto do logotipo, a particularidade do ' $x$ ' aplicado nas outras letras. Acho isso muito interessante

20 LC: Uma informação complementar, quantos pesos tem a Petrobras Sans?

FH: São oito fontes. São quatro pesos do light, regular, bold e extra bold com os itálicos

LC: Small Caps?

FH: Tem o nosso mapa de caracteres padrão latino, mas não tem small Caps.

LC: E algarismos, são alinhados e old style?

FH: São alinhados, tem os tabulários e os proporcionais, mas não tem old style.

25 LC: Ela atende vários idiomas?

FH: São 100 idiomas latinos, que é o nosso mapa de caracteres padrão.

LC: Qual o tempo de desenvolvimento?

FH. Eoram oito meses, entregamos em abril de 2012 e começamos a desenvolver primeiro conceito em 15 junho de 2011 .

C: Quantas pessoas trabalharam no design da fonte?

FH. Foram seis designers e dois developers (engenharia). $O$ devepoler também é um designer.

LC: Eu agradeço muitíssimo a atenção e o tempo de vocês, e se puderem envia lgum material ilustrativo do que tratamos, seria muito útil.

FH: Vou preparar um material para você e te mando.

LC: Vou pedir para retomar essas questões ao longo da pesquisa. Obrigado abraço Fabio; obrigado Fernando. 
(8)<smiles>c1ccccc1</smiles> 
